Maíra Pedreschi Marques Baldassin

\title{
Avaliação do perfil dos linfócitos B de pacientes com Imunodeficiência Comum Variável antes e após administração de antígenos protéicos e polissacarídicos
}

\author{
Tese apresentada à Faculdade de Medicina \\ da Universidade de São Paulo para \\ obtenção do título de Doutor em Ciências \\ Programa de Alergia e Imunopatologia. \\ Orientador (a): Dra. Cristina Maria Kokron.
}

São Paulo 


\section{Dados Internacionais de Catalogação na Publicação (CIP)}

Preparada pela Biblioteca da

Faculdade de Medicina da Universidade de São Paulo

Creprodução autorizada pelo autor

\section{Baldassin, Maíra Pedreschi Marques}

Avaliação do perfil de linfócitos B de pacientes com Imunodeficiência Comum Variável antes e após administração de antígenos protéicos e polissacarídicos / Maíra Pedreschi Marques Baldassin. -- São Paulo, 2014.

Tese(doutorado)--Faculdade de Medicina da Universidade de São Paulo.

Programa de Alergia de Imunopatologia.

Orientadora: Cristina Maria Kokron.

Descritores: 1.Imunodeficiência de Variável Comum 2.Vacinas 3.Vírus da influenza A subtipo H3N2 4. Vírus da influenza A subtipo H1N1 5.Streptococcus pneumoniae 6.Produção de anticorpos 7.Linfócitos B 


\section{Agradecimentos}

Aos pacientes, pois sem eles este trabalho não existiria.

À Dra. Cristina Maria Kokron por todas as oportunidades oferecidas que me proporcionaram um crescimento intelectual e profissional.

Aos professores Jorge Kalil, Edécio Cunha Neto e Esper Georges Kallás pela enorme contribuição durante as reuniões e discussões enriquecedoras.

A Coordenação de Aperfeiçoamento de Pessoal de Nível Superior - CAPES pelo apoio dado através da bolsa de doutorado que me permitiu a realização deste trabalho.

À FAPESP pelo suporte financeiro deste trabalho.

Ao Dr. Cláudio Sérgio Panutti e a Lucy pela acolhida e auxílio durante a realização dos experimentos no Laboratório de Virologia do Instituto de Medicina Tropical.

Ao Instituto Butantan, em especial a Dra. Cosue, do laboratório de Vacina de Influenza, por toda a atenção e ensinamentos dados.

À Andréa Celestino e Andréa Kuramoto por toda a ajuda e sugestões durante a padronização dos ensaios de ELISA e quantificação de proteínas.

Ao Ambulatório de Imunodeficiências Primárias, principalmente à Dra. Myrthes Toledo Barros pela ajuda na revisão dos prontuários além das sugestões.

Aos funcionários Serafim, Maurício e Rosana por toda a ajuda durante a organização e realização das coletas.

Aos doutores Dewton de Moraes Vasconcelos, Karina Carvalho e Daniela Santoro Rosa pelas correções precisas e recomendações que aperfeiçoamento do trabalho. 
A todos os colegas do LIM 60 que durante estes 7 anos de convivência me proporcionaram preciosos ensinamentos profissionais e pessoais.

À Dra. Ana Karolina, companheira diária durante esta jornada, uma grande amiga que com seus ensinamentos enriqueceu cada etapa da realização deste trabalho.

Aos amigos Santa, Bianca, Denise, Maria Angélica, Lidiane, Priscila, Carla e Dona Inês por todo o apoio, conversas, risadas e pela amizade que se propagou aqui fora.

A minha família pela presença durante cada passo da minha jornada, pela torcida incansável e incessante e incentivo em cada etapa.

A todos que contribuíram direta ou indiretamente para a realização deste trabalho 


\section{SUMÁRIO}

Lista de abreviaturas, símbolos e siglas

Lista de figuras

Lista de tabelas

Resumo

Abstract

Sumário

1. INTRODUÇÃ

1.1 Sistema Imune e Imunodeficiências ............................................................. 02

1.2 Imunodeficiência Comum Variável .................................................................... 03

1.3 Ontogenia e Ativação dos Linfócitos B ................................................................ 05

1.4 Alterações Imunológicas e Moleculares em Pacientes com ICV ............................. 08

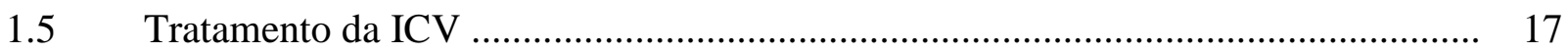

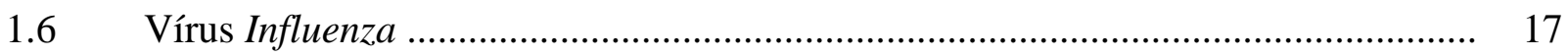

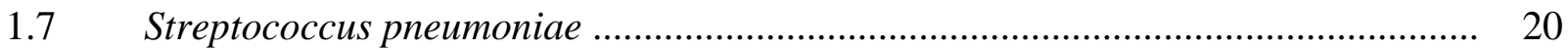

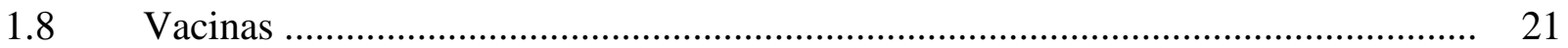

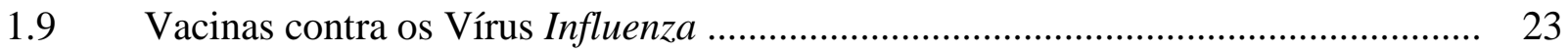

$1.10 \quad$ Vacinas contra Streptoccocus Pneumoniae ......................................................... 25

1.11 Imunizações em Pacientes com ICV ................................................................ 26

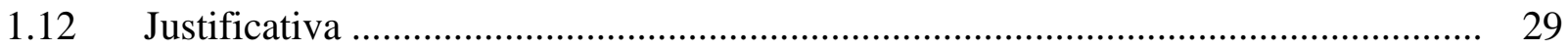

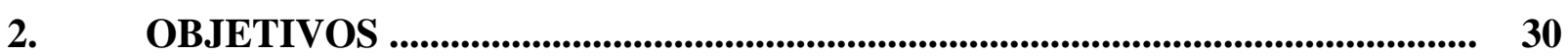

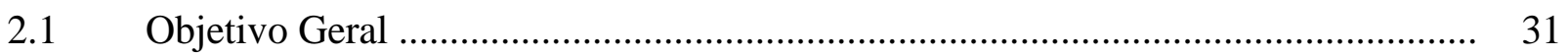

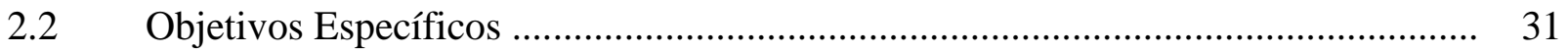

3. CASUÍSTICA E MÉTODOS ............................................................................... 32

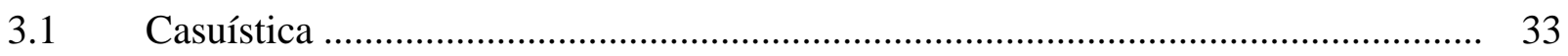

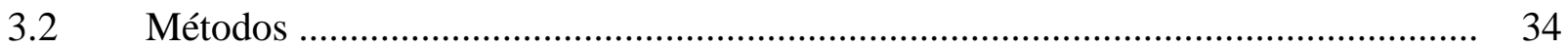

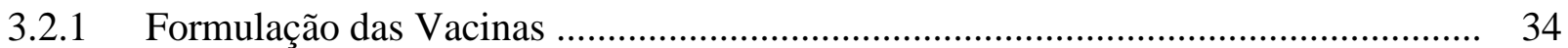

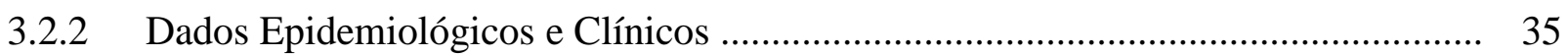

3.2.3 Determinação dos Níveis Séricos de Imunoglobulinas.......................................... 36 
3.2.4 Determinação de Anticorpos Específicos para Influenza ....................................... 36

3.2.5 Determinação de Anticorpos Específicos para H1N1 .......................................... 37

3.2.6 Determinação de Anticorpos Específicos para S. pneumoniae ................................ 39

3.2.7 Obtenção de Células Mononucleares de Sangue Periférico ..................................... 40

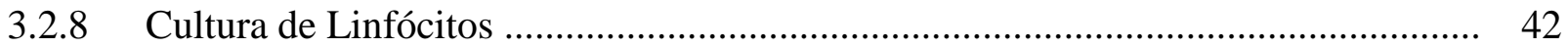

3.2.9 Imunofenotipagem para Identificação das Subpopulações de Linfócitos B ........... 42

3.2.10 Classificação dos Pacientes de Acordo com o Tipo de Resposta Após

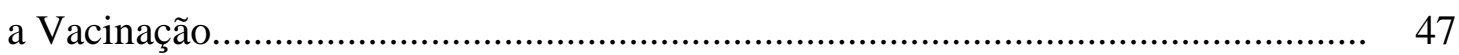

3.2.11 Análise Estatística ........................................................................................... 48

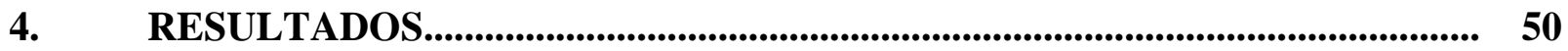

4.1 Dados Epidemiológicos e Clínicos ................................................................. 51

4.2 Dosagem de Imunoglobulinas Séricas............................................................. 56

4.3 Determinação de Anticorpos Específicos para Influenza ...................................... 56

4.4 Determinação de Anticorpos Específicos para H1N1 ............................................ 61

4.5 Determinação de Anticorpos Específicos para Streptococcus pneumoniae ............. 66

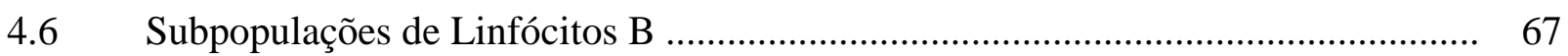

4.7 Classificação dos Pacientes de Acordo com o Tipo de Resposta Após

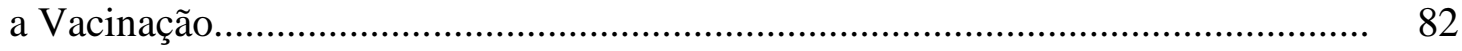

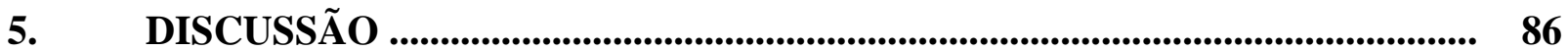

5.1 Dados Epidemiológicos e Clínicos.................................................................. 87

5.2 Dosagem de Imunoglobulinas Séricas e Produção de Anticorpos Específicos......... 90

5.3 Expressão das Subpopulações de Linfócitos B .................................................... 95

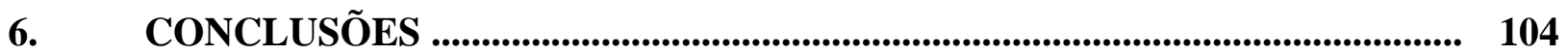

7. REFERÊNCIAS BIBLIOGRÁFICAS ........................................................... 106

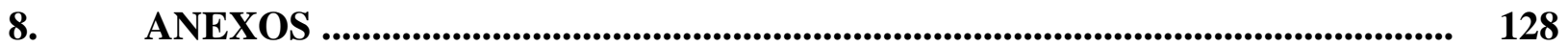

Anexo 1: Termo de Consentimento Livre e Esclarecido .................................... 129

Anexo 2: Aprovação da Cappesq …................................................................. 132

Anexo 3: Score de Sintomas Pré Tratamento com Reposição de Imunoglobulinas. 133 
Anexo 4: Score de Sintomas - Pré Vacinação

Anexo 5: Score de Sintomas Pós Vacinação

Anexo 6: Frequência dos Subtipos de Linfócitos B dos Pacientes com Imunodeficiência Comum Variável - Pré Vacinação

Anexo 7: Valores Absolutos dos Subtipos de Linfócitos B em Pacientes com Imunodeficiência Comum Variável - Pré Vacinação

Anexo 8: Frequência dos Subtipos de Linfócitos B em Indivíduos Controles - Pré Vacinação

Anexo 9: Frequência dos Subtipos de Linfócitos B em Pacientes com Imunodeficiência Comum Variável - Pós 1 Mês

Anexo 10: Valores Absolutos dos Subtipos de Linfócitos B em Pacientes com Imunodeficiência Comum Variável - Pós 1 Mês

Anexo 11: Frequência dos Subtipos de Linfócitos B em Indivíduos Controles Pós 1 Mês

Anexo 12: Frequência dos Subtipos de Linfócitos B em Pacientes com Imunodeficiência Comum Variável - Pós 3 Meses

Anexo 13: Valores Absolutos dos Subtipos de Linfócitos B em Pacientes com Imunodeficiência Comum Variável - Pós 3 Meses

Anexo 14: Frequência dos Subtipos de Linfócitos B em Indivíduos Controles Pós 3 Meses

Anexo 15: Frequência dos Subtipos de Linfócitos B em Pacientes com Imunodeficiência Comum Variável - Pós 6 Meses

Anexo 16: Valores Absolutos dos Subtipos de Linfócitos B em Pacientes com Imunodeficiência Comum Variável - Pós 6 Meses

Anexo 17: Frequência dos Subtipos de Linfócitos B em Indivíduos Controles Pós 6 Meses

Anexo 18: Classificação EUROclass em Pacientes com ICV Após a Subdivisão do Tipo de Resposta Após a Vacinação. 


\section{LISTA DE ABREVIATURAS SÍMBOLOS E SIGLAS}

ADCC

ALEXA 700

APC

$\mathrm{APCCY}_{7}$

APRIL

ATB

BAFF

BCR

BSA

BQ

CAPPESQ

CCR7

$\mathrm{CD}$

CDC

CMSP

CXCR5

$\mathrm{C}_{6} \mathrm{H}_{8} \mathrm{O}_{7} \mathrm{H}_{2} \mathrm{O}$

$\mathrm{dL}$

DNA

DO

ELISA

EMA

ESID

FDA

FITC

FMO

FOXP3

FSC-A

FSC-H

HA

HC-FMUSP

HI

HA

HLA-DR

$\mathrm{H}_{2} \mathrm{O}_{2}$

$\mathrm{H}_{2} \mathrm{SO}_{4}$

ICOS

IDPs

ICV

IFN- $\gamma$

IgA

IgD

IgE
Citotoxicidade Celular Dependente de Anticorpos

Fluorocromo Alexa 700

Fluorocromo Aloficocianina

Fluorocromo Aloficocianina Cy Chrome 7

Proliferation-Inducing Ligand.

Antibioticoterapia

"B Cell Activating Factor" - Fator de Sobrevivência dos linfócitos B

"B cell receptor" - Receptor de Células B

Albumina Sérica Bovina

Bronquiectasias

Comissão de Ética para Análise de projetos de Pesquisa

Receptor 7 de Quimiocina CC que é Expresso em Linfócitos T e B

Ativados

Cluster de Diferenciação

Centers for Disease Control

Células Mononucleares de Sangue Periférico

Receptor 5 de Quimiocina CXC que é Expresso em Linfócitos B e Células Dendríticas

Ácido Cítrico Monohidratado

Decilitro

Ácido Desoxirribonucléico

Densidade Óptica

Enzyme Linked Immunosorbent Assay

Agência Européia de Medicamentos

Sociedade Européia de Imunodeficiências

Food and Drug Administration

Fluorocromo Isoticionato de Fluoresceína

Fluorescence Minus One - Todas as Fluorescências Menos Uma

Forkhead Box P3

Forward Scatter - dispersão frontal da luz que mede a área.

Forward Scatter - dispersão frontal da luz que mede a altura

Hemaglutinina

Hospital das Clínicas - Faculdade de Medicina da Universidade de São

Paulo

Hemaglutinação Indireta

Hemaglutinina

Antígeno Leucocitário Humano da Subclasse DR

Peróxido de Hidrogênio

Ácido sulfúrico

Inducible Co-Stimulator - Molécula Expressa nos linfócitos T

Imunodeficiências Primárias

Imunodeficiência Comum Variável

Interferon-gama

Imunoglobulina A

Imunoglobulina D

Imunoglobulina $\mathrm{E}$ 


\begin{tabular}{|c|c|}
\hline $\operatorname{IgG}$ & Imunoglobulina $\mathrm{G}$ \\
\hline $\operatorname{IgM}$ & Imunoglobulina . \\
\hline Igs & Imunoglobulinas \\
\hline IL-1 & Interleucina 1 \\
\hline IL-2 & Interleucina 2 \\
\hline IL-12 & Interleucina 12 \\
\hline IL-17 & Interelucina 17 \\
\hline IVAS & Infecções das Vias Aéreas Superiores \\
\hline IVIg & Imunoglobulina Humana para Uso Intravenoso \\
\hline $\mathrm{kg}$ & Quilograma \\
\hline LB & Linfócito B \\
\hline LRBA & LPS-Responsive Vesicle Trafficking, Beach And Anchor Containing \\
\hline LT & Linfócito T \\
\hline$\mu \mathrm{g}$ & Micrograma \\
\hline$\mu \mathrm{L}$ & Microlitro \\
\hline $\mathrm{mg}$ & Miligrama \\
\hline $\mathrm{mL}$ & Mililitro \\
\hline MZB & Linfócito B de Zona Marginal \\
\hline $\mathrm{N}$ & Normalidade ou Concentração Normal \\
\hline NA & Neuraminidase \\
\hline $\mathrm{NaCl}$ & Cloreto de Sódio \\
\hline ng & Nanograma \\
\hline NFKB2 & Nuclear factor NF-kappa-B \\
\hline $\mathrm{nm}$ & Nanômetro \\
\hline $\mathrm{Na}_{2} \mathrm{HPO}_{4}$ & Fosfato de Sódio Bifásico Anidro \\
\hline $\mathrm{NaH}_{2} \mathrm{PO}_{4}$ & Fosfato de Sódio Monobásico \\
\hline NK & Células Natural Killer \\
\hline NKT & Células T Natural Killer \\
\hline OD & Densidade Óptica \\
\hline OMS & Organização Mundial da Saúde \\
\hline PAGID & Grupo Panamericano de Imunodeficiências Primárias \\
\hline PBL & Plasmoblastos \\
\hline PBS & Tampão Fosfato-Salino \\
\hline PBS-T & Tampão Fosfato-Salino Acrescido de Tween 20 à $0,05 \%$ \\
\hline PE & Fluorocromo Ficoeritrina \\
\hline $\mathrm{PE}_{-} \mathrm{CY}_{7}$ & Fluorocromo Ficoeritrina Cy-chrome 7 \\
\hline PERCP & Fluorocromo Proteína Clorofilperidina \\
\hline PKC delta & Protein Kinase C Delta \\
\hline PFA $1 \%$ & Paraformaldeído 1\% \\
\hline PWM & Mitógeno Pokeweed \\
\hline RDE & Enzima Comercial Liofilizada que Contém Marcadores Inespecíficos \\
\hline RNA & Ácido Ribonucléico \\
\hline SSC & Side Scatter - Dispersão Lateral da Luz \\
\hline SMB & $\begin{array}{l}\text { Switched Memory B cell - Linfócito B de Memória que Sofreu Troca de } \\
\text { Isotipo }\end{array}$ \\
\hline TACI & $\begin{array}{l}\text { Transmembrane Aactivator and Calcium Modulating Cyclophilin Ligand } \\
\text { Interactor }\end{array}$ \\
\hline TEXAS RED & Fluorocromo Texas Red \\
\hline
\end{tabular}


Linfócito T helper (Auxiliares) tipo 1

Th2

Linfócito T helper (Auxiliares) tipo 2

Th17

Linfócito T helper (Auxiliares) tipo 17

TLR2

Receptor do Tipo Toll 2

TLR3

Receptor do Tipo Toll 3

TLR7

Receptor do Tipo Toll 7

TLR9

Receptor do Tipo Toll 9

TNF

Fator de Necrose Tumoral

Treg

Linfócito T Regulador

$\mathrm{xg}$

Unidade de Aceleração Gravitacional 


\section{LISTA DE FIGURAS}

Figura 1 Casuística das Imunodeficiências Primárias no Complexo HC-FMUSP, 2013 $(\mathrm{n}=1008)$

Figura 2 Ontogenia dos Linfócitos B

Figura 3 Diferenciação entre Variação Antigênica Menor e Maior que Ocorre nos Vírus Influenza.

Figura 4 Distribuição dos Pacientes Participantes do Estudo ........................................ 33

Figura 5 Estratégia de Análise para Identificação e Definição de Linfócitos B ............. 45

Figura 6 Estratégia de Análise Através do FMO ......................................................... 46

Figura 7 Estratégia de Análise para Identificação e Definição das Subpopulações de Linfócitos B

Figura 8 Manifestações Clínicas ....................................................................... 52

Figura 9 Avaliação Clínica ................................................................................ 54

Figura 10 Avaliação Clínica Pós Vacinação - Comparação entre o Número de Vacinas.. 55

Figura 11 Concentração Sérica de IgG .................................................................... 56

Figura 12 Determinação de Anticorpos Específicos para Influenza - Controles ............. 57

Figura 13 Determinação de Anticorpos Específicos para Influenza - Pacientes .............. 58

Figura 14 Determinação de Anticorpos Específicos para Influenza - Comparação entre Pacientes e Controles ....................................................................................... 59

Figura 15 Determinação da Soroproteção para Influenza - Comparação entre Pacientes

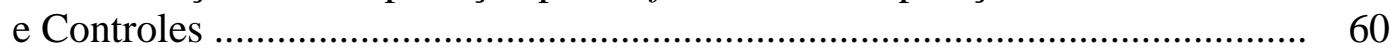

Figura 16 Determinação de Anticorpos Específicos para H1N1 - Controles .................. 61

Figura 17 Determinação de Anticorpos Específicos para H1N1 - Pacientes ................... 62

Figura 18 Determinação de Anticorpos Específicos para H1N1 - Comparação entre Pacientes e Controles ..................................................................................... 63

Figura 19 Determinação da Soroproteção para H1N1 - Comparação entre Pacientes e Controles

Figura 20 Determinação da Soroconversão para H1N1 - Comparação entre Pacientes e Controles

Figura 21 Determinação de Anticorpos Específicos para S. pneumoniae - Sorotipos ...... 67

Figura 22 Frequência da Subpopulação de Linfócito B Naive Pré e Pós Vacinação Contra Influenza

Figura 23 Frequência da Subpopulação de Linfócitos B de Zona Marginal Pré e Pós Vacinação Contra Influenza

Figura 24 Frequência da Subpopulação de Linfócito B de Memória Com Troca de Isotipo Pré e Pós Vacinação Contra Influenza

Figura 25 Frequência da Subpopulação de Plasmoblastos Pré e Pós Vacinação Contra Influenza......

Figura 26 Cinética dos Subtipos de Linfócitos B Após Administração da Vacina de Influenza - Controles

Figura 27 Cinética dos Subtipos de Linfócitos B Após Administração da Vacina de Influenza - ICV .

Figura 28 Frequência da Subpopulação de Linfócitos B Naive Pré e Pós Vacinação contra Influenza - Comparação entre Pacientes e Controles 
Figura 29 Cinética de LB Naive após Administração da Vacina de Influenza e Estimulação com Lisado Viral ou Peptídeo HA - Comparação entre ICV e Controles

Figura 30 Frequência da Subpopulação de Linfócitos B de Zona Marginal Pré e Pós Vacinação contra Influenza - Comparação entre Pacientes e Controles

Figura 31 Cinética de LB de Zona Marginal após Administração da Vacina de Influenza e Estimulação com Lisado Viral ou Peptídeo HA - Comparação entre ICV e Controles

Figura 32 Frequência da Subpopulação de Linfócitos B de Memória com Troca de Isotipo Pré e Pós Vacinação contra Influenza - Comparação entre Pacientes e Controles

Figura 33 Cinética de LB de Memória com Troca de Isotipo Após Administração da Vacina de Influenza e Estimulação com Lisado Viral ou Peptídeo HA Comparação entre ICV e Controles

Figura 34 Frequência da Subpopulação de Plasmoblastos Pré e Pós Vacinação Contra Influenza - Comparação entre Pacientes e Controles

Figura 35 Cinética de Plasmoblastos após Administração da Vacina de Influenza e Estimulação com Lisado Viral ou Peptídeo HA - Comparação entre ICV e Controles

Figura 36 Correlação entre LB de Memória com Troca de Isotipo e Plasmoblastos nos Pacientes com ICV

Figura 37 Classificação dos Pacientes de Acordo com o Perfil de Resposta Após a Vacinação

Figura 38 Avaliação Clínica Após a Classificação dos Pacientes de Acordo com o Perfil de Resposta Após a Vacinação 


\section{LISTA DE TABELAS}

Tabela 1 Prevalência de Imunodeficiência Comum Variável no Mundo

Tabela 2 Principais Alterações Imunológicas em Pacientes com Imunodeficiência Comum Variável

Tabela 3 Alterações Moleculares em Pacientes com Imunodeficiência Comum Variável . 15

Tabela $4 \quad$ Score de Sintomas ....................................................................................... 35

Tabela 5 Anticorpos Utilizados para Marcação de Superfície Celular dos Subtipos de Linfócitos B

Tabela 6 Características Demográficas dos Grupos de Pacientes e Controles que Participaram do Estudo .............................................................................. 51

Tabela 7 Características Clínicas dos Pacientes com ICV ............................................. 53

Tabela 8 Determinação de Anticorpos Específicos para S. pneumoniae - Resultados Individuais .................................................................................................. 66

Tabela 9 Classificação dos Pacientes de Acordo com o Perfil de Resposta Após a Vacinação 


\section{RESUMO}

Baldassin, M.P.M . Avaliação do Perfil dos linfócitos $B$ de pacientes com Imunodeficiência Comum Variável antes e após administração de antígenos protéicos e polissacarídicos [Tese]. São Paulo: Faculdade de Medicina, Universidade de São Paulo; 2014.

Introdução: A Imunodeficiência Comum Variável (ICV) faz parte de um grupo de imunodeficiências primárias na qual os pacientes apresentam defeitos na maturação e diferenciação dos linfócitos B (LB), resultando em distúrbios funcionais além de alterações na distribuição de seus subtipos. Consequentemente, estes pacientes apresentam hipogamaglobulinemia, susceptibilidade a infecções e ausência de produção de anticorpos a antígenos específicos. Na tentativa de reduzir os episódios de infecções recorrentes, alguns trabalhos têm recomendado a vacinação com patógenos mortos ou subunidades e em trabalho anterior demonstramos a eficácia clínica da vacinação de pacientes com ICV, porém, a experiência com a administração de vacinas em imunocomprometidos é limitada. Objetivos: Avaliar a cinética da distribuição das subpopulações de linfócitos B antes e após a vacinação com antígenos proteicos e polissacarídicos em pacientes com ICV acompanhados no Ambulatório de Imunodeficiências Primárias do Hospital das Clínicas, FMUSP, além da produção de anticorpos específicos aos antígenos vacinais. Pacientes e Métodos: Um grupo de 35 pacientes com ICV e 16 controles foram vacinados contra Influenza, H1N1 e $S$. pneumoniae. Após as coletas nos tempos pré e pós 1, 3 e 6 meses foram realizados a separação de PBMC e cultura de linfócitos com lisado viral e hemaglutinina de Influenza, além da citometria de fluxo para identificação das subpopulações de LB naive, zona marginal (MZB), memória com troca de isotipo (SMB) e plasmoblastos (PBL). Foram dosados os anticorpos específicos e no grupo dos pacientes foi aplicado um score de sintomas antes e após a imunização. Resultados: Apesar da redução significativa na pontuação do score de sintomas, a maioria dos pacientes não produziu anticorpos específicos para Influenza, H1N1 e S. pneumoniae. A análise da cinética das subpopulações de LB revelou que em indivíduos saudáveis, a resposta contra Influenza apresentou duração de 6 meses, observada por meio da redução da subpopulação naive e aumento gradual da frequência de SMB a partir do primeiro mês. Observamos também redução da população de memória por volta do $3^{\circ}$ mês, com aumento da população de 
PBL que permaneceu elevada até o $6^{\circ}$ mês. Por outro lado, a despeito de os pacientes apresentarem aumento de SMB no primeiro mês após a vacinação, sua frequência foi inferior ao observado nos controles, decaindo ao terceiro mês. A população de PBL apresentou aumento precoce no primeiro mês após a vacinação, também muito menor do que observado nos controles, não sendo mantido no terceiro mês. Ainda, observamos uma correlação entre o aumento da expressão destas duas subpopulações no primeiro mês. Apenas a população de MZB apresentou aumento significativo no terceiro mês nos pacientes quando comparados aos controles. Ao dividirmos os pacientes de acordo com a expressão de SMB e PBL após 1 mês da administração das vacinas, observamos que os pacientes que apresentaram aumento na expressão de células B de memória foram os que exibiram uma melhora clínica mais expressiva, soroconverteram e desenvolveram soroproteção para H1N1.Conclusões: Apesar de não apresentarem eficaz diferenciação em células de memória e efetoras, resultando na resposta precoce e de curta duração, observamos que os pacientes foram capazes de reconhecer e responder às vacinas. Além disso, a elevada expressão de MZB no terceiro mês após a vacinação pode sugerir a atuação desta subpopulação na apresentação para os LT. Estes achados reforçam a necessidade de uma melhor compreensão da ativação do sistema imune em pacientes com ICV, para uma adequada subdivisão de acordo com o perfil de resposta após a vacinação.

Descritores: Imunodeficiência Comum Variável, Vacinas, Influenza, H1N1, S. pneumoniae, Produção de Anticorpos, Linfócitos B 


\section{ABSTRACT}

BALDASSIN, M.P.M. Evaluation of B lymphocyte profile of Common Variable Immunodeficiency patients before and after immunization with protein and polysaccharide antigens. [Thesis]. São Paulo: Hospital das Clínicas, University of São Paulo, 2014.

Introduction: Common Variable Immunodeficiency (CVID) is a primary antibody deficiency characterized by defects in B lymphocyte maturation, resulting in disturbed differentiation, distribution and functional variations on its subtypes. As a result, CVID patients have hypogammaglobulinemia and poor antibody response to specific antigens with increased susceptibility to infections. In an effort to minimize the recurrent episodes of infections, some studies have recommended immunization with inactivated pathogens or subunits and in a former study we have shown the clinical improvement determined by immunization in CVID patients, but the experience with vaccines' administration to immunodeficient patients is limited. Objectives: To evaluate the changes in distribution of B cell subtypes before and after vaccination of CVID patients followed at the Division of Clinical Immunology and Allergy of University of São Paulo Medical School with protein and polysaccharide antigens, as well as specific antibody production . Methods: A group of 35 CVID patients and 16 controls were vaccinated against Influenza, $\mathrm{H} 1 \mathrm{~N} 1$ and $S$. pneumoniae vaccines. Blood samples were collected before and 1, 3 and 6 months post vaccination. PBMCs were stimulated with Influenza viral lysate and hemagglutinin peptide. Flow cytometry was performed to identify naïve B cells, marginal zone (MZB), switched memory B cells (SMB) and plasmablasts (PBL). Specific antibody production was measured and a symptoms score was applied for clinical evaluation before and after immunization. Results: In spite of the significant reduction in symptoms score after vaccination, most patients didn't produce specific antibodies to Influenza, H1N1 and S. pneumoniae. The analyzes of B cell subtypes changes in healthy individuals upon in vitro Influenza stimulation showed that the response endured up to 6 months post immunization. We observed a reduction in naïve $B$ cell frequency while gradual increase in SMB frequency occurred already at 1 month after vaccination. Moreover, as the memory cell population declined, PBL population increased at the third month post vaccination until the sixth month. Although patients had an increase of SMB on the first month after vaccination, it was lower than that observed in controls, decreasing by the third month 
post vaccination. Plasmablast frequency had an early increase on the first month, also much lower than the observed in controls decreasing by the third month. In addition, we observed a correlation between the increased expression of SMB and PBL on the first month post vaccination. In patients, only MZB subtype presented a significant increase on the third month when compared to controls. We divided the patients according SMB and PBL expression after 1 month post vaccination and we observed that patients who were able to produce memory B cells showed a better clinical improvement, developed H1N1 seroconversion and seroprotection. Conclusion: Despite the defect on differentiation into memory and effector B cells resulting in early response with lowduration, we observed that patients were able to recognize and respond to vaccines. In addition, the over expression of MZB on the third month after vaccination may suggest the role of this subpopulation as an antigen presenting cell for $\mathrm{T}$ cells. These findings reinforce the need of a better understanding of immune system activation and response in CVID patients to propose a division according to vaccine (antigen) responders and non responders.

Descriptors: Common Variable Immunodeficiency, Vaccination, Influenza, H1N1, S. pneumoniae, Antibody Production, B cell. 


\subsection{Sistema Imune e Imunodeficiências}

A integridade do sistema imune é essencial para a defesa contra micro-organismos infecciosos e seus produtos tóxicos, garantindo a sobrevida do indivíduo. Os defeitos em um ou mais componentes do sistema imune podem resultar em doenças potencialmente graves, denominadas imunodeficiências (Abbas, 2008).

As imunodeficiências podem ser divididas em dois grupos: 1) Primárias: quando defeitos genéticos resultam na falha de um ou mais componentes do sistema imune; 2) Secundárias: quando o sistema imune é suprimido por uma variedade de fatores, incluindo estados patológicos, traumas e tratamentos (Abbas, 2008).

Dentro da categoria das imunodeficiências primárias (IDPs), já foram descritos defeitos em mais de 120 genes que foram associados a aproximadamente 200 doenças, porém este número tende a aumentar, devido o fato de muitas doenças ainda não terem um diagnóstico molecular estabelecido (Al-Herz et al., 2014).

De acordo com a última classificação (Al-Hertz et al., 2014), as IDPs estão divididas em nove grupos, de acordo com o componente da resposta imunológica mais comprometido: 1) Deficiências Combinadas; 2) Deficiências Combinadas com Características Associadas ou Sindrômicas; 3) Deficiências Predominantes de Anticorpos; 4) Síndromes de Imunodesregulação; 5) Deficiência do Número e/ou Função de Fagócitos; 6) Deficiências da Imunidade Inata; 7) Síndromes Autoinflamatórias; 8) Deficiências de Sistema Complemento e 9) Fenocópias de IDPs. A figura 1 demonstra a prevalência dos diferentes grupos de IDPs no complexo HCFMUSP, de acordo com a classificação de 2011. Esta distribuição é compatível com as observações relatadas em outras casuísticas (Leiva et al., 2007; Eades-Perner et al., 2007; Knerr, 2007; Carneiro-Sampaio et al., 2013); 

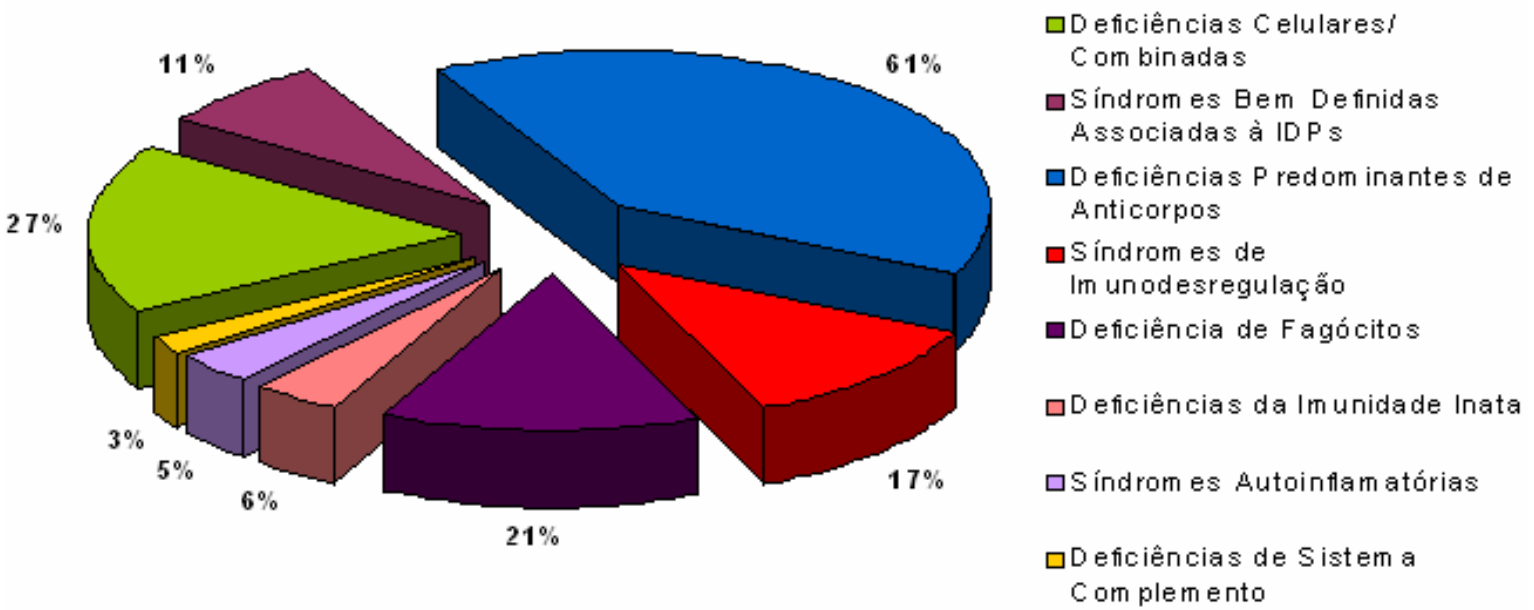

Figura 1: Casuística das Imunodeficiências Primárias no Complexo HC-FMUSP, 2013 (n=1008). As imunodeficiências primárias foram divididas em oito grupos: 1) Deficiências Celulares/ Combinadas; 2) Síndromes Bem Definidas Associadas à IDPs; 3) Deficiências Predominantes de Anticorpos; 4) Síndromes de Imunodesregulação; 5) Deficiência de Fagócitos; 6) Deficiências da Imunidade Inata; 7) Síndromes Autoinflamatórias e 8) Deficiências de Sistema Complemento.

Fonte: Carneiro-Sampaio et al., 2013.

Como pode ser observado na figura 1, o grupo de deficiências de anticorpos representam o tipo de IDP de maior prevalência no complexo HC-FMUSP.

\subsection{Imunodeficiência Comum Variável}

A Imunodeficiência Comum Variável (ICV) foi descrita pela primeira vez em 1953 por Janeway et al., e se insere no grupo de deficiências de anticorpos, pois compreende um grupo de distúrbios heterogêneos que resultam em hipogamaglobulinemia, baixa produção de anticorpos e infecções de repetição (Chapel e Cunningham-Rundles, 2009).

Esta IDP afeta ambos os gêneros de forma equivalente, podendo apresentar-se em qualquer faixa etária, porém tem uma distribuição bimodal, com picos na infância, em torno dos 10 anos ou mais frequentemente na idade adulta, entre a $2^{\mathrm{a}}$ e $3^{\mathrm{a}}$ década de vida (Cunningham-Rundles e Bodian, 1999).

Dentro do grupo das imunodeficiências humorais, a Imunodeficiência Comum Variável merece destaque, pois é a IDP clinicamente sintomática mais relevante, estando a sua prevalência dentro da faixa de 1:25.000 a 1:50.000 (Resnick et al., 2012).

Na tabela 1 encontram-se os dados de prevalência de ICV em diversos países. 
Tabela 1: Prevalência de Imunodeficiência Comum Variável no Mundo.

\begin{tabular}{|c|c|c|c|c|}
\hline Pais & Autores & $\begin{array}{c}\text { Número } \\
\text { de } \\
\text { Pacientes }\end{array}$ & $\begin{array}{c}\text { Populaçåo } \\
\text { em } \\
2000\left[\times 10^{6}\right]\end{array}$ & Prevalência \\
\hline $\begin{array}{c}\text { São Paulo, B rasil } \\
\text { E spanha } \\
\text { Noruega } \\
\text { Irã } \\
\text { Austrália e Nova Zelândia }\end{array}$ & $\begin{array}{l}\text { Grumach et al.(1997)** } \\
\text { Matamoros Flori et al. (1997) } \\
\text { Stray- Pedersen et al. (2000) } \\
\text { Rezai et al. (2006) } \\
\text { Kirkpatrick and Riminton (2007) }\end{array}$ & $\begin{array}{c}101 \\
300(213) \\
303(150) \\
242(195) \\
930\end{array}$ & $\begin{array}{c}157 \\
35 \\
4,45 \\
22 \\
23\end{array}$ & $\begin{array}{l}1: 79000 \\
1: 117000 \\
1: 15000 \\
1: 91000 \\
1: 25000\end{array}$ \\
\hline
\end{tabular}

Fonte: Chapel e Cunningham-Rundles.

** Pacientes pediátricos. 2009.

Clinicamente a ICV está associada a um amplo espectro de complicações que podem surgir em qualquer faixa etária. Uma das principais manifestações clínicas apresentadas por estes pacientes são as infecções de repetição, sendo o sistema respiratório o local de maior susceptibilidade a infecções por micro-organismos encapsulados, como Haemophilus influenzae, Streptococcus pneumoniae, Staphylococcus aureus e algumas vezes também por Mycoplasma spp e agentes virais (Park, 2008; Webster, 2001; CostaCarvalho et al., 2002; Salzer et al., 2012).

No entanto, outras complicações também são descritas ao longo do curso da doença, podendo inclusive preceder o diagnóstico, incluindo as doenças autoimunes, como citopenias autoimunes, artrite reumatóide, vitiligo, tireoidites e também doença celíacalike; diarréia crônica, decorrente de infecções por micro-organismos como Giardia lamblia, Salmonella, Shigella e Campylobacter, podendo levar à síndrome de máabsorção; doenças linfoproliferativas, como a esplenomegalia e a linfadenopatia e processos malignos, sendo que os linfomas e o câncer gástrico são os mais prevalentes (Park, 2008; Ramirez-Vargas et al., 2013; Abolhassani et al., 2013).

Por conta desta variedade de manifestações clínicas descritas em pacientes com ICV, atualmente, eles podem ser divididos em 5 fenótipos clínicos associados às infecções de repetição, são eles: 1) Infecções apenas; 2) Autoimunidade; 3) Doenças linfoproliferativas; 4) Enteropatias e 5) Malignidade (Chapel e Cunningham-Rundles, 2009). 


\subsection{Ontogenia e Ativação dos Linfócitos B}

O desenvolvimento dos linfócitos B (LB) se inicia na medula óssea, a partir de uma célula pluripotente diferenciada para um progenitor linfóide comum que dá origem a um precursor da linhagem de células B. Durante esta fase inicial, caracterizada por ser antígeno independente, ocorre uma variação progressiva e diversificada da recombinação das cadeias leves e pesadas das imunoglobulinas (Igs), além do receptor de células B (BCR) (Abbas, 2008; Desjardins e Mazer, 2013).

A célula da medula óssea predestinada à linhagem de LB em seu estágio mais inicial é identificada por expressar as moléculas CD10 e CD22 e não é capaz de produzir Igs, sendo denominada linfócito Pró B. No estágio seguinte do seu desenvolvimento, o linfócito é denominado Pré B e é caracterizado pela expressão do receptor pré-BCR, responsável pela expansão das células $\mathrm{B}$ e sua subsequente diferenciação para células imaturas, além da molécula de superfície CD19 (Abbas, 2008; Warnatz e Schlesier, 2008; Kurosaki, 2010).

Com o aparecimento de CD20, o receptor de células B (BCR) e a expressão da IgM de membrana, o LB passa a ser considerado imaturo, porém estas células não são capazes de proliferar nem responder a antígenos específicos. A coexpressão de IgM e IgD na superfície celular do LB, caracteriza sua competência funcional, tornando estas células responsivas a antígenos. Nesta etapa do seu desenvolvimento, o LB passa a ser identificado como LB naive e migra da medula óssea para a corrente sanguínea (Abbas, 2008; Warnatz e Schlesier, 2008).

O LB naive transpõe um novo estágio do seu desenvolvimento quando passa a expressar as moléculas CD21 e CD38, sendo esta última, um marcador de ativação celular. Nesse estágio do seu desenvolvimento, passa a ser empregada a denominação de LB Transitório e esta célula migra da corrente sanguínea para o órgão linfóide secundário, geralmente o baço (Mackay et al., 2003; Warnatz e Schlesier, 2008).

Dando sequência na diferenciação dos LB, o LB Transitório no órgão linfóide secundário, ao ser apresentado a um antígeno estranho ao qual ele apresente especificidade, pode se diferenciar em 2 subpopulações: LB de zona marginal (MZB) e LB folicular, dando assim início à resposta imune humoral (Kurosaki, 2010; Desjardins e Mazer, 2013). 
O LB de zona marginal expressa em sua superfície $\operatorname{IgM}$ e $\operatorname{IgD}$, além da molécula CD27, caracterizando-o como uma célula B de memória. Esta célula representa de 15\% a $25 \%$ do total de células B circulantes e atua na produção precoce de anticorpos, além de estar associada à defesa contra bactérias encapsuladas (Carsetti et al., 2004; Weller et al., 2004; Haymore et al., 2007; Desjardins e Mazer, 2013).

Já os linfócitos B foliculares são células que estão geralmente envolvidas na resposta humoral T dependente, são caracterizados pela expressão das moléculas CD21, CD23 e IgM de membrana, porém não expressam a molécula CD27 e participam na diferenciação de outras 2 subpopulações de LB logo após a sua ativação frente a presença de um antígeno estranho: linfócitos B de memória com troca de isotipo (SMB) e plasmoblastos (PBL) (Warnatz e Schlesier, 2008; Desjardins e Mazer, 2013).

Os linfócitos B de memória com troca de isotipo, também são considerados células B de memória, devido à expressão de CD27, porém deixam de expressar $\operatorname{IgM}$ e $\operatorname{IgD}$ na sua superfície celular e passam a expressar outras imunoglobulinas de membrana (IgG/IgA/IgE). Sua frequência aumenta de acordo com a idade e representam $40 \%$ do total de células B na circulação de adultos (Agematsu et al., 2000; Ahn e CunninghamRundles, 2009).

Plasmoblastos são células B caracterizadas pela alta expressão de CD27 e CD38, além de também serem caracterizadas pela ausência de imunoglobulinas de membrana (Warnatz e Schlesier, 2008).

Assim como o MZB e o SMB, os plasmoblastos caem na corrente sanguínea, porém com a finalidade de voltarem para a medula óssea, onde sofrem um último estágio de diferenciação, tornando-se plasmócitos ou células B efetoras. Os plasmócitos são definidos pela alta expressão das moléculas CD38 e CD138 (este sendo marcador celular específico de plasmócitos) e também pela secreção de grande quantidade de imunoglobulinas antígeno-específicas (Warnatz e Schlesier, 2008).

Recentemente, em análises por citometria de fluxo, foi identificado um novo subtipo de LB, caracterizado pela baixa expressão de CD21, CD38, CXCR5, CCR7 e CD23 e pela alta expressão de CD19, assim como IgM de membrana. Esta célula foi denominada de $\mathrm{LB}$ CD2 $1^{\text {low }}$ e apresenta características muito semelhantes a células imaturas, porém seu papel fisiológico ainda não está bem definido (Moir et al., 2001; Warnatz et al., 2002). Até o momento, sabe-se que esta subpopulação de LB apresenta baixa resposta linfoproliferativa após ativação via BCR, além de baixa expressão de 
marcadores relacionados a homeostase, em contrapartida apresentam alta expressão de receptores de quimiocinas pró inflamatórias (Rakhmanov et al., 2009). Em pacientes com HIV, sugere-se que teriam características autoreativas, parecendo uma população de LB inatos ou então LB CD21 ${ }^{\text {low }}$ esgotados (Rakhmanov et al., 2009; Rakhmanov et al., 2010). A figura 2 demonstra os estágios de desenvolvimento dos LB.

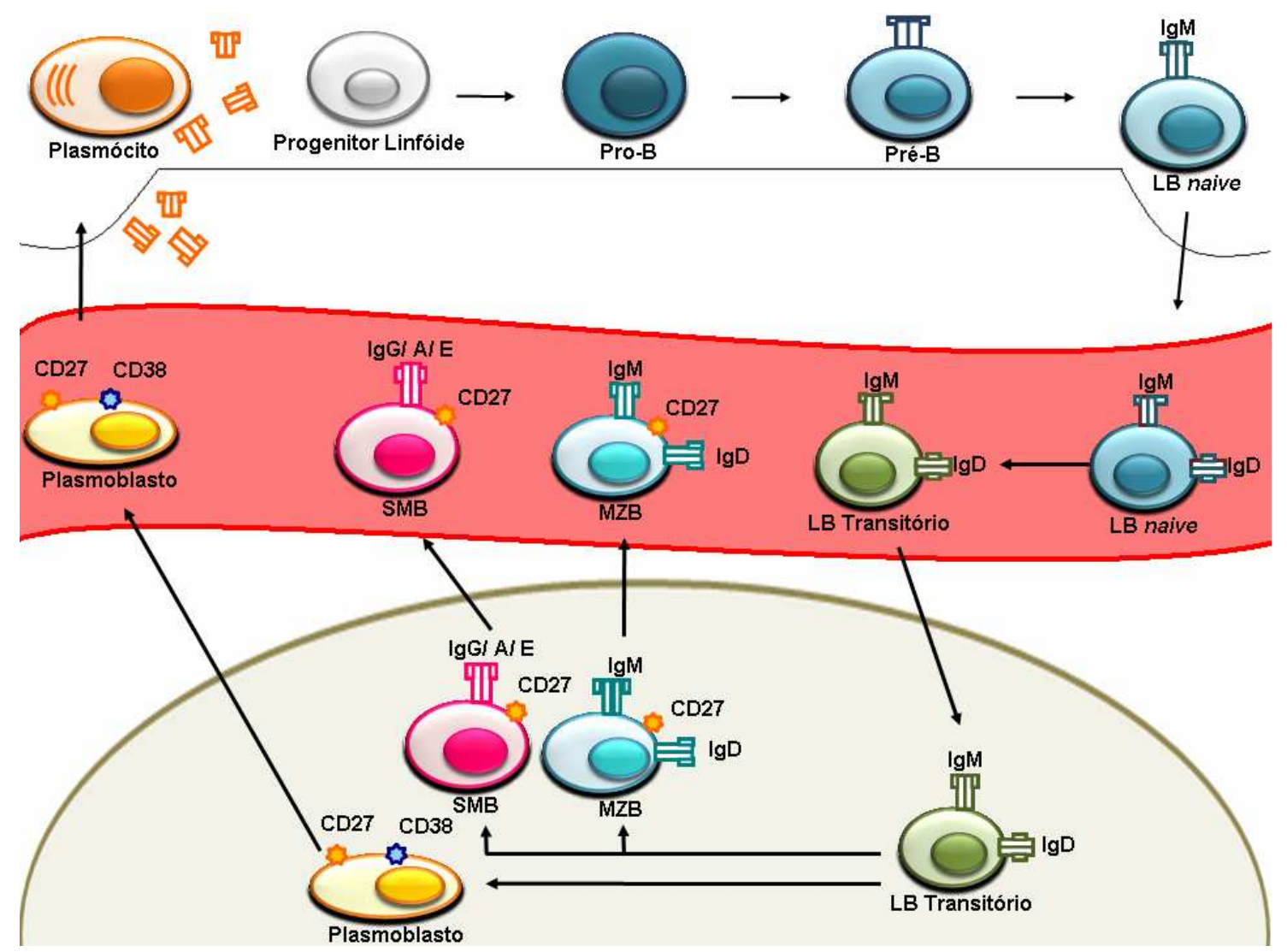

Figura 2: Ontogenia dos Linfócitos B. SMB: LB de memória com troca de isotipo; MZB: LB de zona marginal. Fonte: própria.

Diferentes tipos de antígenos são capazes de induzir uma resposta imune humoral por meio de diversos mecanismos (Lindroth, 2004).

O processo de reconhecimento e ativação dos LB pode ser dividido em resposta $\mathrm{T}$ dependente, quando após o contato com um antígeno protéico, os LB precisam interagir com os LT, por meio de moléculas e sinais coestimulatórios para que possam se diferenciar em células de memória e efetora e resposta $\mathrm{T}$ independente, a qual é direcionada contra antígenos polissacarídicos e lipídeos, não necessitando do auxílio 
dos LT e produzindo anticorpos com uma menor afinidade em comparação a resposta $\mathrm{T}$ dependente (Lindroth, 2004; Abbas, 2008).

A ativação dos LB e a geração de plasmócitos e células de memória se inicia com a fase de reconhecimento, que ocorre por meio da interação do antígeno com o LB naive. A partir deste contato se inicia a fase de ativação, ocorrendo a expansão clonal dos LB naive e sua diferenciação para células efetoras e de memória (Abbas, 2008; Kelly et al., 2005; Good-Jacobson e Tarlinton, 2012).

Quando as células B de memória encontram novamente o mesmo antígeno, elas são ativadas novamente, proliferam e se diferenciam em plasmócitos de forma mais rápida, conferindo uma maior produção de anticorpos específicos do que o que foi gerado no primeiro encontro antigênico (Kelly et al., 2005).

\subsection{Alterações Imunológicas e Moleculares em Pacientes com ICV}

Por se tratar de uma doença heterogênea e mais provavelmente um conjunto de várias doenças, diversos defeitos em diferentes tipos celulares já foram descritos em pacientes com ICV, envolvendo componentes da resposta inata, celular e humoral.

As células dendríticas apresentam um papel crucial na indução da resposta adaptativa, seja por meio da apresentação direta de antígenos aos LT ou por meio da ativação dos LB, através da interação das moléculas CD40-CD40L (Banchereau e Steinman, 1998; Stockwin et al., 2000). A partir desta interação, ocorre a regulação da maturação e diferenciação dos LB naive em plasmócitos e, consequentemente, secreção de imunoglobulinas. Pacientes com ICV apresentam diferenciação, maturação e função das células dendríticas alteradas, resultando na falha da ativação dos LB (Bayry et al., 2004; Scott-Taylor et al., 2004; Viallard et al., 2005).

Anormalidades em monócitos também foram descritas, já que alguns pacientes apresentaram células com alto estresse oxidativo, levando à deficiente proliferação de LT, assim como também na produção de IL-2, além disso, alguns pacientes apresentam monócitos com baixa capacidade de produção das citocinas TNF e IFN- $\gamma$, determinando a falha na diferenciação de LT naive para o perfil Th1. Clinicamente, estes defeitos estão sendo associados à autoimunidade e granulomatose (Aukrust et al., 1994; Aukrust et al., 1996; Cambronero et al., 2000; Scott-Taylor et al., 2004; Bonilla e Geha, 2009). 
Dados recentes indicam que pacientes com ICV apresentam baixa frequência de células NK e NKT, resultando em falhas envolvendo o sistema imune inato e também humoral e maior susceptibilidade a doenças oportunistas (Fulcher et al., 2009; Carvalho et al., 2010; Trujillo et al., 2011).

Quanto à imunidade celular, alguns pacientes apresentam linfopenia relativa e absoluta de linfócitos $\mathrm{T} \mathrm{CD}^{+}$e/ou número normal ou aumentado de linfócitos $\mathrm{T}$ CD8 ${ }^{+}$ determinando a inversão da relação $\mathrm{CD}^{+} / \mathrm{CD}^{+}$(Vasconcelos e Duarte,1989). No grupo de pacientes com ICV acompanhados no complexo HC-FMUSP, em levantamento realizado em 2004, 56\% (40/71) dos pacientes apresentavam esta inversão (Kokron et al., 2004).

Vários defeitos já foram descritos em relação aos LT, como proliferação defeituosa dos linfócitos $\mathrm{T}$ naive, reduzida ativação celular, aumento de apoptose, produção anormal de citocinas do perfil Th1 e expressão reduzida de CD40L que resultam na falha da ativação dos LB e consequentemente na troca de isotipo. Alguns pacientes podem apresentar persistente ativação dos LT, com aumento na expressão de HLA-DR e diminuição de L-selectina, e em outros há um predomínio de células $\mathrm{T} \gamma \delta$ (Pinchuk et al., 1996; Schoreder et al., 1998; Webster et al., 2001; Bayry, 2005).

Uma das subpopulações dos $\mathrm{LT} \mathrm{CD} 4^{+}$caracterizada pela alta produção de IL-17 é denominada linfócito Th17. Esta célula apresenta papel muito importante na resposta imune contra bactérias e fungos e também tem sido associada a algumas doenças autoimunes, como a esclerose múltipla, artrite reumatoide e psoríase. Recentemente, as células Th17 estão sendo associadas à diferenciação de LB e na manutenção dos LT foliculares, porém em pacientes com ICV, sua frequência encontra-se reduzida (Barbosa et al., 2011).

Os linfócitos $\mathrm{T}$ reguladores (Treg) fazem parte de outra subpopulação dentro do grupo dos $\mathrm{LT} \mathrm{CD}^{+}$que estão diretamente envolvidas na manutenção da homeostase do sistema imunológico. Fevang et al. (2007) observaram que a baixa frequência de Tregs em pacientes com ICV está associada com processos de inflamação crônica, o que também foi verificado por Horn et al. (2009). No mesmo ano, Genre et al. (2009) mostrou comprometimento da expressão de FOXP3 nas células $\mathrm{T}$ reguladoras e diminuição do número destas células nos pacientes com ICV que apresentavam autoimunidade. 
Em relação aos LB, a maioria dos pacientes com ICV apresenta número normal ou pouco reduzido, porém estas células têm um fenótipo característico de células imaturas, apresentando dificuldade na diferenciação para célula efetora e de memória (Warnatz et al., 2002; Ko et al., 2005; Schaffer et al., 2007; Cunningham-Rundles, 2012).

Schwartz (1999) verificou que pacientes com ICV apresentam células B incapazes de proliferar e/ou diferenciar-se, fenômeno associado a defeito da cascata de transdução de sinal intracelular via fosforilação de proteínas tirosinadas.

Morbach et al. (2010), estudando as subpopulações de LB, verificaram que a frequência de LB naive e LB Transitório diminuem consideravelmente no decorrer dos anos em indivíduos saudáveis, porém pacientes com ICV apresentam um aumento na frequência destas duas subpopulações (Lawrence, 2009; Mouilot et al., 2010; Vlková et al., 2010). Em 2008, Wehr et al., também verificaram o aumento nestas duas subpopulações, sendo que o aumento na população naive estava relacionado à presença de linfadenopatia. Estes dados também foram observados por Mouilot et al. (2010).

Com o passar dos anos, indivíduos saudáveis apresentam um aumento gradativo das subpopulações de LB de memória, já pacientes com ICV apresentam redução tanto na população de $\mathrm{MZB}^{1}$ quanto de $\mathrm{SMB}^{2}$ (Muramatso et. al., 2000; Sánchez-Ramón et al., 2008).

A redução de MZB faz com que os pacientes com ICV sejam mais susceptíveis a infecções por Streptococcus pneumoniae e apresentem resposta deficiente à imunização contra pneumococos além de desenvolver dano pulmonar progressivo (Carsetti et al., 2004; Haymore et al., 2007).

Em 2006, Alachkar et al., verificaram a correlação entre a diminuição de SMB e o aumento da prevalência de bronquiectasias e autoimunidade, quando comparados aos pacientes com frequências maiores.

Outra subpopulação cujas anormalidades foram associadas a manifestações clínicas foi a de plasmoblastos (PBL). Em 2007, Castigli et al., verificaram considerável redução na frequência desta subpopulação em pacientes com ICV e Wehr et al. (2008) verificaram uma correlação inversa entre autoimunidade e a frequência de PBL, pois os

\footnotetext{
${ }^{1}$ MZB: LB de Zona Marginal

${ }^{2}$ SMB: LB de Memória com Troca de Isotipo
} 
pacientes com redução deste subtipo de LB apresentavam maior prevalência de doenças autoimunes.

Por fim, em relação aos $\mathrm{LB}$ CD21 ${ }^{\text {low }}$, foi observado que pacientes com ICV apresentam uma frequência maior deste subtipo celular que indivíduos saudáveis, e este aumento está relacionado a maior prevalência de esplenomegalia e granulomatose (Wehr et al., 2008; Mouillot et al., 2010). A seguir, na tabela 2 estão descritas as principais alterações imunológicas em pacientes com ICV. 
Tabela 2: Principais Alterações Imunológicas em Pacientes com Imunodeficiência Comum Variável.

\begin{tabular}{|c|c|c|}
\hline Tipo Celular & Alteração & Referência \\
\hline $\begin{array}{l}\text { Células } \\
\text { Dendríticas }\end{array}$ & $\begin{array}{ll}\text { - } & \text { CD40-CD40L; } \\
\text { - } & \text { Sinalização defeituosa de TLR9; } \\
\text { - } & \text { Maturação diminuída; } \\
\text { - } & \text { Produção de citocinas alterada. }\end{array}$ & $\begin{array}{l}\text { Banchereau e Steinman, } 1998 . \\
\text { Bayry et al., } 2004 . \\
\text { Scott-Taylor et al., } 2004 . \\
\text { Viallard et al., } 2005 . \\
\text { Bonilla e Geha, } 2009 .\end{array}$ \\
\hline Monócitos & $\begin{array}{ll}\text { - } & \text { Produção de TNF, IL-2 e IFN- } \gamma \text {; } \\
\text { - } & \text { Alto estresse oxidativo. }\end{array}$ & $\begin{array}{l}\text { Aukrust et al.; } 1994 . \\
\text { Aukrust et al.; } 1996 .\end{array}$ \\
\hline Células NKT & - Baixa frequência. & Carvalho et al., 2010. \\
\hline Células NK & - Baixa frequência. & Trujillo et al., 2011. \\
\hline Linfócitos $\mathrm{T}$ & 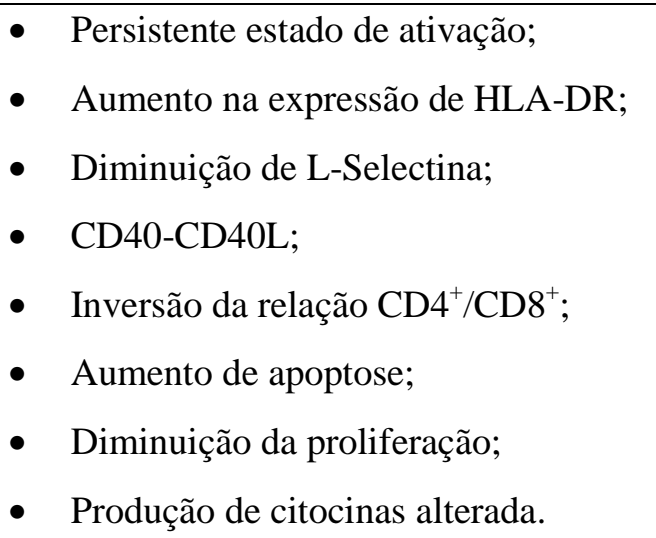 & $\begin{array}{l}\text { Webster , } 2001 . \\
\text { Pinchuk et al., } 1996 \\
\text { Kokron et al., } 2004 . \\
\text { Bonilla e Geha, } 2009 .\end{array}$ \\
\hline Linfócitos Th17 & - Baixa frequência. & Barbosa et al., 2011. \\
\hline Linfócitos Treg & - $\quad$ Baixa frequência. & Bonilla e Geha, 2009. \\
\hline Linfócitos B & 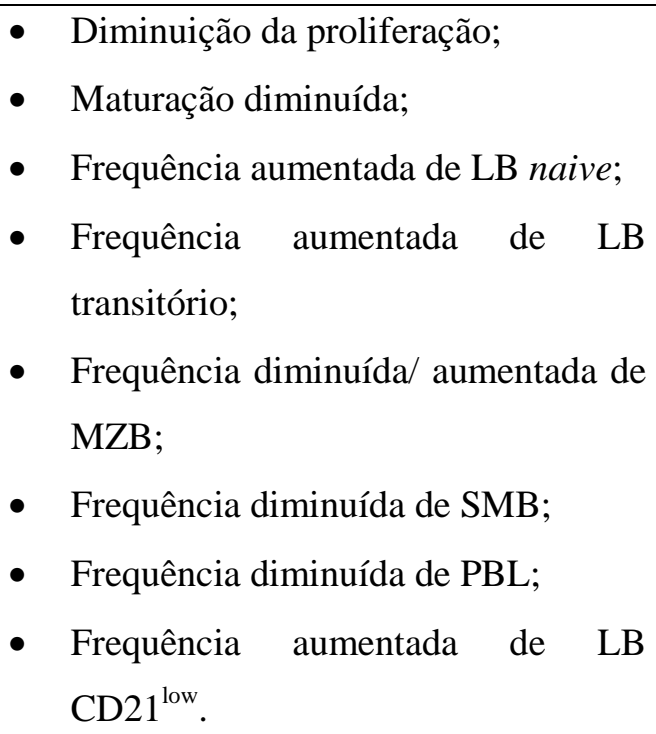 & $\begin{array}{l}\text { Schwartz, } 1999 . \\
\text { Muramatso et. al., } 2000 . \\
\text { Sánchez-Ramón et al., } 2008 . \\
\text { Mouilot et al., } 2010 . \\
\text { Vlková et al., } 2010 . \\
\text { Castigli et al., } 2007 . \\
\text { Wehr et al.,2008. }\end{array}$ \\
\hline
\end{tabular}


Contrastando com outras imunodeficiências primárias, mais de $90 \%$ dos pacientes com ICV não apresentam um diagnóstico molecular. Atualmente 11 defeitos genéticos já foram identificados, porém estas alterações são raras e estão presentes em apenas $3 \%$ dos pacientes, são elas: ICOS; TACI; BAFFR; APRIL; CD19; CD20; CD21, CD81, LRBA, PKC delta e NFKB2 (Salzer et al., 2013, La Cava, 2013; Chen et al., 2013). A seguir, estão descritas as principais alterações moleculares.

$\mathrm{O}$ primeiro defeito genético associado com a ICV foi relacionado à deficiência da molécula ICOS (Inducible co-stimulator) que está presente em linfócitos $\mathrm{T}$ e atua na ativação e diferenciação dos LB naive para células de memória e plasmócitos, após o contato com seu ligante presente nos linfócitos B. Grimbacher et al. (2003), verificaram que os pacientes que apresentavam considerável redução de SMB, apresentavam defeitos na expressão desta molécula e estes dados também foram observados em 2004 por Salzer et al.

A molécula TACI (Transmembrane activator and calcium modulating cyclophilin ligand interactor) atua no desenvolvimento, homeostase e produção de anticorpos dos LB e as mutações nesta molécula estão sendo associadas a doenças linfoproliferativas (Schneider, 2005; Park et al., 2008). Em 2007, Castigli et al. verificaram que pacientes com mutações na molécula TACI apresentavam defeitos na diferenciação de PBL para plasmócitos, assim como na produção de $\operatorname{IgG}, \operatorname{IgM}$ e $\operatorname{IgA}$.

Mutações em BAFF (B cell activating factor), molécula expressa em algumas células apresentadoras de antígenos, têm sido descritas como possíveis responsáveis pelo bloqueio na sobrevida e maturação dos LB Transitórios. Esta molécula se liga a três receptores distintos presentes nos LB: TACI; BAFF-R (B cell activating factor receptor) e APRIL (Proliferation inducing ligand), estando estas duas últimas moléculas associadas a regulação da sobrevida e apoptose durante a ontogenia e desenvolvimento da resposta imune (Thompson et al., 2001; Sasaki et al., 2004; ShulgaMorskaya et al., 2004; Kuribayashi et al., 2008)

Dentre as várias moléculas presentes na membrana celular dos LB maduros, um conjunto composto por 4 proteínas merece destaque devido sua atuação em conjunto com o BCR na ativação dos LB, são elas: CD19, CD21, CD81 e CD225. Em 2006, Van Zelm et al., descreveram mutações na molécula CD19 em pacientes com deficiência de anticorpos e em 2010, o mesmo autor também descreveu mutações envolvendo a molécula CD81. Mais recentemente, Thiel et al., 2012, descobriram alterações 
envolvendo a molécula CD81 e alterações no gene de CD21 em pacientes com deficiência na produção de anticorpos e em 2010, Kuijpers et al., descreveram mutações na molécula CD20 resultando na baixa produção de imunoglobulinas. A tabela 3 descreve as principais alterações moleculares descritas em pacientes com ICV. 
Tabela 3: Alterações Moleculares em Pacientes com Imunodeficiência Comum Variável.

\begin{tabular}{|c|c|c|c|c|}
\hline Alteração & Localização & Função & Quadro Clínico & Frequência \\
\hline ICOS & $\cdot \mathrm{LT}$. & - Ativação e Diferenciação dos LB. & $\begin{array}{l}\text { - } \downarrow \text { IgG, IgM, IgA; e contagem de LB; } \\
\text { - Infecções Respiratórias; } \\
\text { - Autoimunidade. }\end{array}$ & 11 pacientes. \\
\hline TACI & $\cdot$ LB. & $\begin{array}{l}\text { - Troca de isotipos em LB; } \\
\text { - Homeostase dos LB; } \\
\text { - Regulação da Resposta T independente; }\end{array}$ & $\begin{array}{l}\text { - } \downarrow \text { IgG, IgM e IgA; } \\
\text { - Presença ou não de Infecções; } \\
\text { - Autoimunidade; } \\
\text { - Doenças Linfoproliferativas. }\end{array}$ & $7 \%-10 \%$. \\
\hline BAFF & $\begin{array}{l}\text { - Células Dendríticas; } \\
\text { - Macrófagos; } \\
\text { - Neutrófilos. }\end{array}$ & - Sobrevida e maturação dos LB. & • Hipogamaglobulinemia com IgM normal ou diminuída. & 2 pacientes. \\
\hline APRIL & $\begin{array}{l}\text { - Células Dendríticas; } \\
\text { - Macrófagos; } \\
\text { - Neutrófilos. }\end{array}$ & $\begin{array}{l}\text { - Regulação da sobrevida e apoptose dos } \\
\text { LB. }\end{array}$ & $\begin{array}{l}\text { - } \downarrow \text { IgG, IgM e IgA; } \\
\text { - Autoimunidade; }\end{array}$ & 1 paciente. \\
\hline CD19 & - LB. & - Ativação de LB. & $\begin{array}{l}\cdot \downarrow \text { IgG, IgM, IgA e LB; } \\
\text { • } \downarrow \text { da Imunidade Celular; } \\
\text { - Pneumonias e Infecções Respiratórias de Repetição; } \\
\text { - Autoimunidade. }\end{array}$ & 9 pacientes. \\
\hline CD20 & $\cdot \mathrm{LB}$. & - Ativação e regulação dos LB. & $\begin{array}{l}\cdot \downarrow \text { IgG, IgM e IgA; } \\
\text { • } \downarrow \text { de LB de Memória; } \\
\text { • Infecções Respiratórias de Repetição. }\end{array}$ & 1 paciente. \\
\hline
\end{tabular}




\begin{tabular}{|c|c|c|c|c|}
\hline Alteração & Localização & Função & Quadro Clínico & Frequência \\
\hline $\mathrm{CD} 21$ & $\begin{array}{l}\text { - LB; } \\
\text { - Células Dendríticas. }\end{array}$ & - Ativação de LB. & $\begin{array}{l}\text { - Hipogamaglobulinemia; } \\
\text { - Resposta Normal a Antígenos Polissacarídeos. }\end{array}$ & 1 paciente. \\
\hline CD81 & - LB. & - Ativação de LB. & $\begin{array}{l}\bullet \downarrow \text { IgG com IgM, IgA diminuída ou normal; } \\
\bullet \downarrow \text { de LB de Memória; } \\
\text { • Infecções Respiratórias de Repetição; } \\
\bullet \text { Plaquetopenia Autoimune; } \\
\text { •Resposta Deficiente a Antígenos Protéicos e Polissacarídeos. }\end{array}$ & 1 paciente. \\
\hline LRBA & $\begin{array}{l}\cdot \text { LB } \\
\cdot \text { Macrófagos }\end{array}$ & $\begin{array}{l}\text { - Secreção ou Deposição de moléculas } \\
\text { efetoras na membrana celular. }\end{array}$ & $\begin{array}{l}\text { - Hipogamaglobulinemia; } \\
\text { - Autoimunidade. }\end{array}$ & 5 pacientes \\
\hline PKC delta & - LB & $\begin{array}{l}\text { - Regulação da sobrevida e apoptose dos } \\
\text { LB. }\end{array}$ & $\begin{array}{l}\text { - } \downarrow \text { de LT CD4 }{ }^{+} ; \\
\text {- Alterações em Células NK; } \\
\text { - Infecções Sinopulmonares; } \\
\text { - Linfadenopatia; } \\
\text { - Infecções por Citomegalovirus e/ou Epstein-Barr. }\end{array}$ & 1 paciente \\
\hline NFKB2 & - Vários tipos celulares & $\begin{array}{l}\text { - Fator de Transcrição da ativação e } \\
\text { regulação celular. }\end{array}$ & $\begin{array}{l}\text { - Hipogamaglobulinemia na Infância; } \\
\text { - Infecções de Repetição; } \\
\text { - Autoimunidade. }\end{array}$ & 4 pacientes \\
\hline
\end{tabular}

Fonte: Keestra, 1988; Finck et al., 2006; Park et al., 2008; Salzer et al., 2012; Lopes-Herrera et al., 2012; La Cava, 2013; Abolhassani et al., 2013; Salzer et al., 2013; Chen et al., 2013. 


\subsection{Tratamento da ICV}

O tratamento da ICV tem a finalidade de reduzir a morbimortalidade e o número de infecções, sendo feito através da reposição de imunoglobulina ( $\operatorname{IgG}$ ) humana, por via endovenosa ou subcutânea, além do acompanhamento multidisciplinar (Muscaritoli et al., 2001; Jolles, 2013).

No Brasil, a reposição de imunoglobulina geralmente é realizada por via endovenosa a cada 3 a 4 semanas na dose de 300 a $600 \mathrm{mg} / \mathrm{Kg}$, com objetivo de manter níveis séricos capazes de proteger o paciente das infecções (Eijkhout et al., 2001; Orange, 2012).

Além disso, é necessário instituir tratamentos específicos para cada uma das complicações clínicas que podem surgir durante o curso da doença (Eijkhout et al., 2001; Park, 2008).

\subsection{Vírus Influenza}

O vírus Influenza faz parte da família Orthomyxoviridae e está dividido em 3 diferentes gêneros: Influenzavirus $A$; Influenzavirus $B$ e Influenzavirus $C$, porém são relevantes para a saúde humana apenas os gêneros $\mathrm{A}$ e $\mathrm{B}$, devido ao fato de sofrerem maior variação antigênica e serem responsáveis pela maioria das epidemias (Wright et al., 2007; Girard et al., 2005).

O vírus Influenza é esférico ou ligeiramente alongado, com $100 \mathrm{~nm}$ de diâmetro, sendo composto por 0,8 a $1 \%$ de RNA fita simples; $70 \%$ de proteínas; $20 \%$ de lipídeos e $5 \%$ a $8 \%$ de carboidratos. Seu genoma viral é recoberto por um capsídeo e por um envelope lipídico derivado de uma parte da célula hospedeira. Na superfície do vírus estão presentes 2 glicoproteínas que desempenham importante papel na sua antigenicidade e patogenia: Hemaglutinina (HA) e Neuraminidase (NA), sendo responsáveis pela adsorção e fusão do vírus à célula hospedeira e clivagem com a membrana citoplasmática da célula (Couceiro, 2002; Palese et al., 2007).

A patogênese da infecção pelos vírus Influenza se inicia com a colonização e replicação do vírus no trato respiratório, onde as partículas virais sofrem adsorção às células hospedeiras. Após a adsorção, ocorre a endocitose, com posterior fusão do 
envelope viral com a membrana do endossomo. No citoplasma da célula infectada, o material genético do vírus é liberado do nucleocapsídeo, onde, chegando ao núcleo da célula, ocorre a transcrição e replicação do genoma viral. Por fim, ocorre a síntese das proteínas virais, a montagem e a liberação dos novos vírus, por meio de brotamento, resultando na lise das células hospedeiras (Couceiro, 2002).

Após os macrófagos e células dendríticas realizarem a fagocitose das células infectadas, a resposta imune contra o vírus Influenza atua por meio da ativação de linfócitos $\mathrm{T} \mathrm{CD}^{+}$, que se diferenciam para o perfil Th1 e passam a produzir IFN- $\gamma$ e IL2, mas a principal atuação é decorrente dos linfócitos T $\mathrm{CD} 8^{+}$, que após serem ativados adquirem um perfil citotóxico e passam a liberar granzimas e perforinas, que agem levando a célula infectada à apoptose. Além disso, também ocorre a ativação dos linfócitos B que passam a produzir anticorpos neutralizantes para as proteínas HA e NA, inibindo assim, a entrada do vírus nas células hospedeiras, além de auxiliar o processo de fagocitose e de citotoxicidade celular dependente de anticorpos (ADCC) promovida pelas células natural killer (NK) (Kreijtz et al., 2011).

Do ponto de vista da Saúde Pública, devido a sua elevada transmissibilidade, distribuição geográfica global, gravidade das manifestações clínicas e do potencial pandêmico, os vírus Influenza podem ser classificados em sazonal, pandêmico ou com potencial pandêmico (Brasil, 2009b).

Segundo a OMS (2011), as gripes sazonais são responsáveis por 250.000 a 500.000 mortes anualmente, sendo que as crianças e idosos são os grupos mais susceptíveis, porém pacientes com imunodeficiências e portadores de doenças cardiopulmonares também representam grupos de risco para maior gravidade da infecção (Foster et al., 1992; Gorse et al., 1997; Succi et al., 2006; Brasil, 2009b; OMS, 2009).

Os vírus pandêmicos ou com potencial pandêmico se espalham globalmente e apresentam elevada taxa de indivíduos infectados e de mortalidade. Os vírus dos grupos A e B estão associados às pandemias, devido à capacidade aumentada deles sofrerem contínuas mutações, resultando no surgimento de novas cepas e na susceptibilidade das populações frente aos novos subtipos virais (Malik et al., 2009).

A ocorrência das epidemias pelos vírus Influenza na população humana é o resultado de variações antigênicas que ocorrem principalmente nas glicoproteínas $\mathrm{HA}^{3}$ e $\mathrm{NA}^{4}$,

\footnotetext{
${ }^{3}$ HA: Hemaglutinina

${ }^{4}$ NA: Neuraminidase
} 
permitindo ao vírus escapar da neutralização de anticorpos e assim, tornando a população susceptível apesar das infecções anteriores. Estas variações antigênicas podem ocorrer de duas maneiras. A primeira delas é chamada de mutação antigênica menor (antigenic drift), onde ocorrem mutações pontuais nos genes que codificam as moléculas HA e NA, resultando no surgimento de novas cepas virais, contra as quais o sistema imune apresenta pouca ou nenhuma proteção prévia. O segundo tipo de variação que pode ocorrer é denominado mutação antigênica maior (antigenic shift), processo no qual duas ou mais cepas diferentes do vírus, que podem ser oriundas de vírus que infectam apenas o ser humano, como também de outros seres vivos, como por exemplo aves e suínos, se rearranjam e formam um novo subtipo que apresenta na sua superfície moléculas HA e/ou NA completamente novas, oriundas das cepas originais (Girard et al., 2005). A figura 3 descreve os processos de variação antigênica menor e maior que ocorrem nos vírus Influenza.
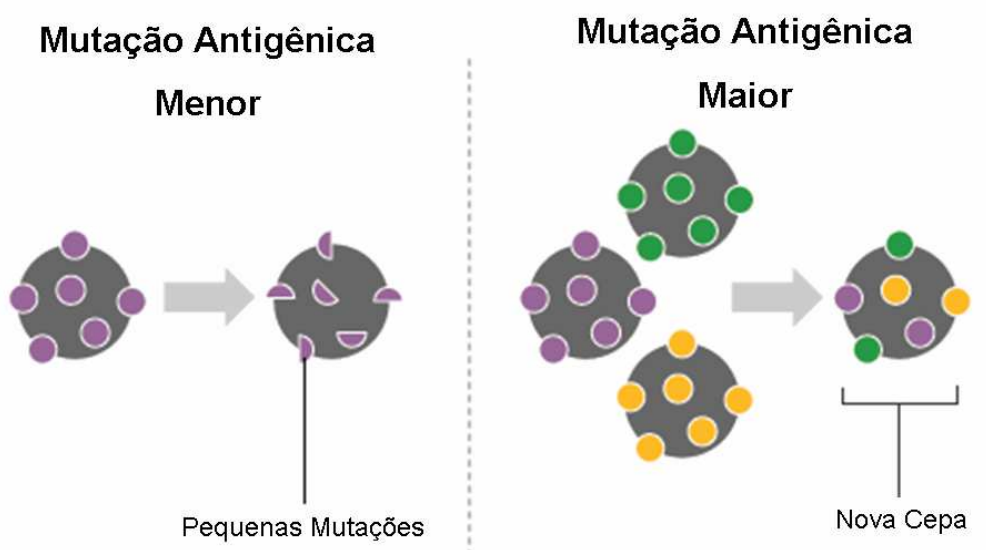

Figura 3: Diferenciação Entre Variação Antigênica Menor e Maior que Ocorre nos Vírus Influenza. Fonte: http://news.bbc.co.uk/2/hi/health/8021799.stm.

Os vírus Influenza são responsáveis por inúmeras epidemias que ocorrem anualmente, entretanto podem ocasionar pandemias globais podendo infectar de $20 \%$ a $40 \%$ da população em um único ano. Geralmente, elas ocorrem nos meses de inverno em países de clima temperado e no sul e sudeste do Brasil, porém em locais de clima tropical, podem ocorrer em qualquer época do ano e muitas vezes, mais de uma vez ao ano, podendo estar associadas às estações chuvosas (Murphy et al., 1996; Cox et al., 1999;Arruda et al., 1999; Taubenberger et al., 2001). 
Durante o século passado ocorreram três importantes pandemias: Gripe Espanhola, primeira forma do vírus H1N1 que surgiu em humanos, em 1918; Gripe asiática, causada pelo vírus H2N2, entre os anos de 1957 a 1960 e a de Hong Kong (H3N2) entre 1968 a 1972 (Cugini et al., 2010).

Em junho de 2009, a primeira pandemia de Influenza do século 21 foi relatada, onde foi identificado um novo vírus H1N1, oriundo da recombinação gênica das cepas virais humanas, cepas de suíno norte americano e eurasiano e cepas da gripe aviária norte americana e foi responsável por 284.000 mortes (CDC, 2010).

\subsection{Streptococcus pneumoniae}

O Streptococcus pneumoniae ou pneumococo é uma bactéria Gram positiva, encapsulada, anaeróbia facultativa e que se apresenta na forma de pares (diplococos) (Kim e Weiser, 1998; Dowson, 2004; Tortora et al., 2005).

A superfície do pneumococo é formada por 3 estruturas distintas: membrana plasmática; parede celular, composta por vários polissacarídeos e cápsula polissacarídica, base da diferenciação sorológica do pneumococo (Dowson, 2004).

A membrana plasmática é composta por uma bicamada lipídica, algumas proteínas e moléculas de ácido lipoteicóico. Já a parede celular é composta por polissacarídeos e ácido teicóico ancorado a diversas proteínas. O polissacarídeo $\mathrm{C}$ é o mais conhecido, devido ao fato de ser encontrado em todos os sorotipos do pneumococo e ser o principal fator responsável pela intensa resposta inflamatória durante a infecção (Kim e Weiser, 1998; Tonnaer et al., 2006).

A patogenicidade do $S$. pneumoniae está relacionada à cápsula, o qual constitui seu principal fator de virulência e também o protege da fagocitose. Os polissacarídeos capsulares apresentam diferentes características estruturais e imunológicas, que permitiram a sua classificação em diferentes sorotipos. Até o momento já foram identificados 91 sorotipos, sendo que 23 deles estão relacionados à maioria das doenças pneumocócicas. No Brasil existem cerca de 10 sorotipos mais prevalentes, sendo os sorotipos 1 e 6B prevalentes em todas as idades, o sorotipo 14 responsável pela maioria das infecções em crianças e os sorotipos 3 e 4 mais comuns em adultos (Hyams et al., 2010; Maley, 2010; Ferreira et al., 2013). 
A patogênese da infecção pelo $S$. pneumoniae se inicia pela colonização da nasofaringe, seguida de sua disseminação pelo ouvido médio, trato respiratório inferior e em alguns casos, invasão da corrente sanguínea. A colonização do pneumococo depende inicialmente da sua capacidade de aderência ao epitélio do trato respiratório, por meio de uma protease que é capaz de clivar a $\operatorname{IgA}$ secretora presente na mucosa. Logo após a aderência, alguns componentes da parede celular são liberados e promovem a produção das citocinas interleucina - 1 (IL-1) e fator de necrose tumoral (TNF), que além de alterarem o número e os receptores nas células epiteliais, também alteram a afinidade do pneumococo a estes receptores, promovendo então, a migração pelo epitélio respiratório e endotélio vascular, resultando assim, no acesso da bactéria a circulação sanguínea (Bogaert et al., 2004; Ferreira et al., 2013).

Além da fagocitose e a morte intracelular pelos macrófagos alveolares e neutrófilos, a resposta imune contra o $S$. pneumoniae envolve também a participação dos linfócitos B e sua diferenciação para plasmócitos secretores de anticorpos, porém devido a presença da cápsula polissacarídica, o pneumococo é capaz de induzir a produção preferencialmente de IgM e IgG2 pelos linfócitos B e não conferindo a formação de memória imunológica (Ferreira et al., 2013).

As infecções pneumocócicas podem ocorrer durante todo o ano, porém devido a fatores predisponentes como viroses e o aumento da poluição atmosférica, são mais frequentes durante o inverno e de acordo com a estimativa da OMS (2000), por ano são relatados 1,4 milhão de casos de doença pneumocócica em crianças, sendo responsável por 735 mil mortes. Além de crianças abaixo dos 3 anos de vida, indivíduos tabagistas, alcoólatras ou que apresentem condições médicas crônicas, como diabetes, doenças cardíacas, pulmonares, renais e imunossupressoras fazem parte do grupo de risco para desenvolvimento da doença (Rubins et al., 1998; Dagan e Lipsitch, 2004; Baldy, 2005; Berezin et al., 2007; Cardoso et al., 2008; Ferreira et al., 2013).

\subsection{Vacinas}

O confronto entre o homem e os agentes patogênicos vem ocorrendo desde os primórdios da humanidade e apesar dos avanços tecnológicos, as doenças infecciosas 
ainda são responsáveis por $20 \%$ das mortes globais e por um número ainda maior de sequelas (Amato Neto, 2011).

A imunologia moderna originou-se do sucesso da vacina do médico Edward Jenner contra a varíola, em 1796, onde ele administrou o pus causado pela infecção da varíola de vacas em um menino e posteriormente, após a inoculação da varíola humana, verificou que o menino apresentava uma proteção e não desenvolvia a doença. Desde então o estudo de vacinas passou a ser aprimorado, devido ao fato delas induzirem proteção contra o patógeno pela qual são desenvolvidas por meio da estimulação e desenvolvimento de células efetoras e de memória de vida longa. Atualmente as vacinas estão divididas em 6 tipos: 1) Vacinas de organismos vivos atenuados ou mortos; 2) Vacinas de subunidades; 3) Vacinas conjugadas; 4) Vacinas sintéticas; 5) Vacinas de vetores virais e 6) Vacinas de DNA (Abbas et al., 2008).

As vacinas de organismos vivos atenuados ou mortos são compostas de microrganismos não patogênicos intactos e são feitas de modo que ele não possa causar a doença, por meio da destruição do microrganismo, porém conservando a sua imunogenicidade. A vantagem no uso deste tipo de vacina está centrada no fato delas serem capazes de desencadear tanto a resposta inata quanto a adquirida e por conta disto serem efetivas na indução de imunidade protetora (Abbas et al., 2008).

Outro tipo são as vacinas de subunidades, que são compostas de antígenos purificados de microrganismos ou toxinas inativadas e necessariamente precisam ser administradas com um adjuvante. Tais vacinas agem como hapteno-carreadores e são capazes de gerar uma reposta adquirida envolvendo tanto linfócitos $\mathrm{T} \mathrm{CD}^{+}$quanto linfócitos $\mathrm{B}$, porém não são capazes de desenvolver uma resposta imunológica por linfócitos T citotóxicos potentes (Abbas et al., 2008).

Alguns antígenos apresentam uma baixa capacidade de ativar o sistema imune, como por exemplo, um polissacarídeo, que induz a ativação da resposta imunológica $T$ independente. Por conta disto, estes antígenos são administrados junto a outros aos quais conseguem conferir uma potente resposta imunológica, sendo geralmente utilizadas proteínas, como as do toxóide tetânico, em mínimas concentrações. O produto final deste processo recebe o nome de vacina conjugada (Murphy et al., 2010). 
As vacinas com antígenos sintéticos surgiram do avanço das pesquisas na identificação dos antígenos ou epítopos antigênicos mais imunogênicos dos microrganismos para sintetizá-los em laboratório e utilizá-los como vacinas (Abbas et al., 2008).

Outra abordagem para o desenvolvimento de vacinas é a introdução de genes que codificam antígenos microbianos em um vírus não citopático e administrá-lo em indivíduos. A grande vantagem da sua utilização é que estas vacinas induzem a ativação de uma resposta imune integral, contemplando também a resposta de linfócitos $\mathrm{T}$ citotóxicos, porém o grande problema na sua utilização é que os vírus utilizados como vetores vivos na vacina podem infectar várias células do hospedeiro e mesmo não sendo patogênicos podem produzir antígenos que induzam a ativação da resposta imune, limitando assim o seu uso. (Abbas et al., 2008).

Por fim, as vacinas de DNA foram desenvolvidas após a inoculação de um plasmídeo contendo DNA complementar (DNAc) que codificava um antígeno protéico, gerando assim, uma resposta celular e humoral forte e duradora contra o antígeno. Este tipo de vacina também é capaz de induzir o desenvolvimento de uma resposta imune integral, devido ao fato de as proteínas antigênicas serem desenvolvidas no citosol da célula transfectada e, além disso, os plasmídeos bacterianos podem ser reconhecidos por vários receptores do tipo Toll, acentuando ainda mais o desenvolvimento de uma resposta adquirida e tornando-as efetivas mesmo quando não são administradas com adjuvantes. A facilidade de manipulação, capacidade de armazenamento e a coexpressão de outras proteínas capazes de acentuar a resposta imunológica tornam esta técnica promissora. Entretanto, os fatores que determinam a eficácia das vacinas de DNA em seres humanos ainda não estão completamente definidos. (Abbas et al., 2008).

\subsection{Vacinas contra os Vírus Influenza}

A vacinação anual contra o vírus Influenza sazonal representa uma medida eficaz e de grande impacto na redução das doenças respiratórias, seja nas gripes ou em decorrência das suas complicações (Machado, 2010).

Atualmente as vacinas contra o vírus Influenza disponíveis são compostas pelo vírus inativado completo, particulado, por meio de antígenos virais purificados e vírus vivo atenuados ou virossomal (Machado, 2010). 
As vacinas inativadas são compostas por 3 cepas do vírus, sendo 2 do tipo A e uma do tipo B, relacionadas as cepas circulantes de cada ano. Em sua maioria, os vírus são replicados em ovos embrionados, são inativados em formalina e após vários processos físico-químicos para purificação, o produto final é composto por $15 \mu \mathrm{g}$ de hemaglutinina de cada cepa viral. Estas vacinas foram desenvolvidas para prevenir a infecção em crianças a partir de 6 meses de vida e inicialmente elas eram empregadas com o vírus inteiro inativado sendo posteriormente desenvolvidas com fragmentos do vírus, passando assim, a serem denominadas de vacinas particuladas, ou com antígenos purificados, conhecidas como vacinas de subunidades (Jofre et al., 2005; Amato Neto, 2011).

As vacinas com o vírus inteiro foram as primeiras a serem desenvolvidas, apresentam boa imunogenicidade e são indicadas para crianças acima de 12 anos, pelo fato de apresentarem alta reatogenicidade em crianças abaixo desta faixa etária (Cintra et al., 2006; Amato Neto, 2011).

Devido ao fato destas vacinas apresentarem baixa aceitação em decorrência de serem administradas pela forma injetável, passaram a ser desenvolvidas as vacinas de vírus vivos atenuados, a qual permitiam a sua administração pela via intranasal. Estas vacinas oferecem elevada segurança, eficácia e imunogenicidade, porém apresentam a desvantagem de não poderem ser administradas em crianças pequenas, idosos e pacientes com imunossupressão, sendo indicadas para o público alvo de 5 a 49 anos (Bergen et al., 2004; Jofre et al., 2005; Piedra et al., 2005; Wright et al., 2007).

Por fim, também estão disponíveis as vacinas virossomais, nas quais o vírus Influenza também se encontra inativado sendo compostas pelos antígenos de superfície HA e NA incorporados a vesículas lipídicas, que atuam como adjuvantes (Huckried et al., 2005).

Em relação às vacinas contra o vírus Influenza-H1N1, em 2009, o FDA (Food and Drug Administration) aprovou a utilização da vacina monovalente inativada e fracionada de aplicação intramuscular e também pela via intranasal. Atualmente, existe também a vacina trivalente, a qual é formulada em associação a vacina de Influenza sazonal (Amato Neto, 2011).

No Brasil estão disponíveis até o momento as vacinas do tipo inativadas, contendo os fragmentos de hemaglutinina, neuraminidase e cápsula do vírus Influenza (Cintra et al., 2006). 


\subsection{Vacinas contra $S$. pneumoniae}

As vacinas anti-pneumocócicas disponíveis são baseadas nos polissacarídeos capsulares livres ou conjugadas a uma proteína carreadora.

A primeira vacina a ser comercializada, surgiu em 1977 e era composta por 14 sorotipos do S. pneumoniae, porém em 1983 ela foi substituída por uma formulação contendo 23 sorotipos, a qual é utilizada até os dias atuais sob os nomes de Pneumovax 23 (Merck Sharp \& Dohme, Whitehouse Station, N.J., EUA) e Pneumo 23 (Sanofi Pateur AS, Lyon, França). A vacina pneumocócica 23-valente não é conjugada e é composta pelos sorotipos: 1, 2, 3, 4, 5, 6B, 7F, 8, 9N, 9V, 10A, 11A, 12F, 14, 15B, 17F, 18C, 19A, 19F, 20, 22F, 23F e 33F. Esta vacina foi desenvolvida para prevenir a infecção em adultos e crianças maiores de 2 anos de idade, onde nesta faixa etária foi possível observar uma cobertura de $90 \%$ contra pneumonia, meningite e bacteremia. Por induzir a resposta $\mathrm{T}$ independente, a Pneumovax 23 não é capaz de produzir memória imunológica, assim os níveis de anticorpos específicos declinam após 4 a 7 anos da sua administração. A resposta vacinal varia conforme a idade, fatores genéticos e nutricionais, mostrando menor efeito protetor em indivíduos imunocomprometidos (Ferreira et al., 2013).

Neste contexto, passaram a ser desenvolvidas vacinas contra o pneumococo a qual estivessem conjugadas a proteínas que modificaram a resposta imune contra os polissacarídeos, induzindo também uma resposta $\mathrm{T}$ dependente, com estabelecimento de memória imunológica (Ferreira et al., 2013).

Assim a vacina heptavalente anti-pneumocócica conjugada com uma toxina diftérica mutada (PNCRM7, PCV7-CRM, Prevenar $7^{\circledR}$ ou PCV7 ${ }^{\circledR}$ - Wyeth Pharmaceuticals, Madison, N.J., EUA) foi desenvolvida e é composta pelos sorotipos: 4, 6B, 9V, 14, 18C, 19F e 23F. Esta vacina foi licenciada em 2001 no Brasil e apresenta resultados satisfatórios para doença invasiva, pneumonias e otites em crianças menores de 2 anos e também em adultos, porém sua cobertura vacinal é baixa, em torno de 58\% (Moretti et al., 2007; Mantese et al., 2009).

Outras formulações de vacinas baseadas em polissacarídeos conjugados foram desenvolvidas, como por exemplo, as vacinas 10-valente (Synflorix ${ }^{\mathrm{TM}}$ ou PHiD-CDGlaxo Smith Kline Biologicals, Brentford, Middlesex, Inglaterra) e 13-valente (Prevenar $13^{\circledR}$, PCV13-CRM ou PCV13 ${ }^{\circledR}$ - Wyeth Pharmaceuticals) (De Schutter et al., 2006). 
A vacina 10-valente é composta pelos sorotipos: 1, 4, 5, 6B, 7F, 9V, 14, 18C, 19F e $23 \mathrm{~F}$ conjugados com a proteína $\mathrm{D}$ do $H$. influenzae, toxóide diftérico e toxóide tetânico e a vacina 13-valente apresenta os sorotipos 3, 6A e 19A além dos sorotipos que compõem a vacina 10-valente. Ambas estas vacinas foram desenvolvidas com o intuito de substituir a vacina 7-valente, pelo fato de além de apresentarem imunogenicidade, segurança e tolerabilidade semelhantes são capazes de conferir uma proteção a um número maior de sorotipos e apresentam uma cobertura vacinal de 90\% (Vesikari et al., 2009).

\subsection{Imunizações em Pacientes com ICV}

Apesar das vacinas não conseguirem proteger o organismo da entrada de um patógeno, elas devem fornecer proteção suficiente para prevenir a instalação da doença e evitar sua transmissão (Graham e Bracialle, 1997).

A experiência da administração de vacinas em pacientes com deficiências imunológicas ainda hoje é limitada, sendo a sua eficácia definida através da natureza e o grau de imunossupressão do indivíduo (Bonilla et al., 2005).

De maneira geral, as vacinas com patógenos vivos devem ser evitadas em pacientes com imunidade específica gravemente comprometida, já as vacinas com patógenos inativados ou subunidades podem ser administradas por não apresentarem riscos ao paciente (Bonilla et al., 2003; Shearer et al., 2014).

Tendo em vista que a resposta imunológica dos pacientes com ICV frente às vacinas pode ser ineficiente ou ausente, a indicação de vacinação com patógenos inativados ou partículas tem gerado grande discussão, principalmente quanto à capacidade que estes pacientes teriam em responder a antígenos específicos e, portanto na eficácia da vacinação e não nos riscos que a vacina poderia causar (Goldacker et al., 2007).

Em 2007, Goldacker et al., estudaram a resposta vacinal de 21 pacientes com ICV após a administração das vacinas contra Tétano, Difteria, $H$. influenzae, hepatites A e B e S. pneumoniae e a avaliação da resposta vacinal foi feita através da determinação de anticorpos específicos durante o período de 1 ano. Em relação à vacinação para $H$. influenzae, o autor verificou que seis pacientes apresentaram aumento nos títulos de $\operatorname{IgG}$ específico, o mesmo foi observado para hepatite A e B onde, 1 e 4 pacientes respectivamente apresentaram um aumento no nível sérico de $\operatorname{IgG}$ específico para estas 
vacinas. Entretanto, para as vacinas contra Tétano e Difteria não foi possível verificar aumento na produção de anticorpos específicos. Por fim, a avaliação da resposta vacinal após a administração da vacina Pneumovax 23, revelou que 9 pacientes não foram capazes de produzir $\operatorname{IgM}$ e $\operatorname{IgG}$ específicos para os sorotipos testados, 1 paciente produziu apenas $\operatorname{IgM}$ específico e 2 pacientes foram capazes de produzir $\operatorname{IgG}$ específico contra S. pneumoniae. Assim, os autores puderam concluir que apesar da heterogeneidade da etiologia e do comprometimento de alguns mecanismos imunológicos da doença, alguns pacientes apresentaram capacidade de responder a estes antígenos.

Esta capacidade de resposta a antígenos específicos também foi observada em pacientes brasileiros, onde Souza et al., (2007), estudaram a resposta linfoproliferativa contra tétano em 36 pacientes e após 1 mês da vacinação contra tétano, observou que após a cultura de linfócitos por 6 dias com o toxóide tetânico, $66 \%$ dos pacientes obtiveram índice de estimulação específica acima de 10, sendo considerado excelente.

Após ter sido verificado que o vírus Influenza era responsável por alta frequência de infecções respiratórias em pacientes com ICV, sua indicação de vacinação foi sugerida (Smith et al., 2006). Em 2005, Junker et al., verificaram que alguns pacientes apresentavam resposta reduzida, porém não ausente, entretanto apontaram algumas dificuldades na avaliação da resposta humoral em pacientes com ICV, principalmente devido a transmissão de anticorpos específicos por meio da infusão de IVIg, assim como o fato de a maioria dos ensaios para avaliação da resposta vacinal serem realizados por meio da quantificação de anticorpos, fato que poderia gerar uma certa dificuldade por se tratar de uma doença onde ocorre a falha na produção de anticorpos, os autores sugeriram em uma carta editorial que pacientes com ICV não seriam capazes de responder à vacina de Influenza. Entretanto, em 2008, Park et al., passaram a recomendar sua administração em pacientes que fazem reposição mensal de imunoglobulinas, recomendação justificada pela improvável presença de anticorpos contra Influenza no preparado de gamaglobulina humana.

Recentemente, Pedersen et al., (2011) avaliaram a resposta humoral e celular contra Influenza sazonal e Influenza $\mathrm{H} 1 \mathrm{~N} 1$ em 3 pacientes com ICV. Após a administração das vacinas foi realizado o acompanhamento nos tempos de 7, 2142 e 90 dias, sendo que na terceira visita, os pacientes receberam uma segunda dose das vacinas. Os autores verificaram que apesar da baixa produção de anticorpos específicos e LT CD4 ${ }^{+}$ 
produtores de IFN- $\gamma$, estes pacientes apresentaram resposta antígeno específica contra Influenza e enfatizaram a indicação desta vacina em pacientes com ICV.

No mesmo ano, Van Assen et al., (2011) vacinaram 15 pacientes contra as vacinas de Influenza sazonal e Influenza $\mathrm{H} 1 \mathrm{~N} 1$ e avaliaram a produção de anticorpos específicos, assim como a produção de IFN- $\gamma$ por linfócitos $\mathrm{T} \mathrm{CD}^{+}$e $\mathrm{T} \mathrm{CD}^{+}$por meio dos ensaios de ELISPOT e citometria de fluxo. Os autores verificaram que apesar da baixa produção de anticorpos, houve um aumento de $\operatorname{LTCD}^{+}$e $\mathrm{TCD}^{+}$produtores de IFN- $\gamma 1$ mês após a vacinação.

Em relação à vacina contra Neisseria meningitidis, em 2006 Rezaei et al., estudando 16 crianças diagnosticadas com ICV, observaram que 68,8\% apresentaram resposta à vacinação e em 2008, os mesmos autores verificaram que os títulos protetores de anticorpos contra o $S$. pneumoniae de 25 pacientes duraram até 3 semanas após a vacinação. Neste trabalho também foi possível verificar que dentre o grupo de pacientes que não apresentaram resposta específica, houve maior frequência de bronquiectasias, doenças autoimunes e esplenomegalia. Recentemente, em 2008, os mesmos autores avaliaram novamente os títulos de anticorpos após um ano da administração das vacinas e observaram que os pacientes que haviam apresentado baixos títulos de anticorpos 3 semanas após a vacinação mantiveram a baixa dosagem e dos 15 pacientes que haviam apresentado resposta normal, apenas 9 mantiveram títulos protetores de anticorpos após 1 ano da vacinação.

Em 2012, Marinho et al., avaliaram a resposta clínica à imunização contra Influenza sazonal, Influenza-H1N1 e S. pneumoniae em 53 pacientes com ICV acompanhados no nosso serviço (HC-FMUSP) por meio da aplicação de um score de sintomas que pontuou de 0 a 5 os parâmetros: pneumonias, sinusites, otites, infecções das vias aéreas superiores, amigdalites, bronquiectasias, hospitalizações e uso de antibióticos. Os autores verificaram uma redução significativa da pontuação do score de sintomas para infecções das vias aéreas superiores, sinusites e pneumonias durante os 12 meses subsequentes à administração das vacinas no grupo de pacientes vacinados comparados aos pacientes que não foram vacinados, reforçando ainda mais os benefícios da vacinação em pacientes com imunodeficiências primárias.

Em 2013, Cavaliere et al., avaliaram a frequência das populações de LB naive, MZB, $\mathrm{SMB}, \mathrm{LB}$ transitório e LB CD2 $1^{\text {low }}$ além da produção de $\operatorname{IgM}$ e $\operatorname{IgA}$ específicos contra 
os sorotipos 1, 3, 4 e 14 do S. pneumoniae. Foram coletadas amostras de 125 pacientes nos períodos pré e 4 semanas após a vacinação com a vacina Pneumovax 23 e apesar de não ter sido observado um aumento significativo entre os períodos pré e pós vacinação no grupo dos pacientes, tanto para $\operatorname{IgM}$ quanto para $\operatorname{IgG}$, os autores conseguiram subdividir os pacientes em respondedores e não respondedores, por meio do qual puderam verificar que os pacientes que não haviam respondido à vacina apresentaram maior incidência de pneumonias e bronquiectasias além da baixa frequência das populações de MZB e SMB quando comparados com o grupo dos pacientes respondedores.

Até o momento, os trabalhos publicados têm sugerido que o conceito de que pacientes com imunodeficiências humorais não são capazes de responder à vacinação pode não estar totalmente correto, porém, mesmo demonstrando que alguns pacientes com deficiências humorais são capazes de responder especificamente a determinadas vacinas, ainda hoje poucos avanços foram feitos no entendimento dos mecanismos envolvidos na ativação da resposta imune antígeno específica de pacientes com ICV após a vacinação (Goldacker et al., 2007).

\subsection{Justificativa}

A avaliação da capacidade de resposta às vacinas e a influência da vacinação na evolução clínica, principalmente com relação ao número de infecções, pode reforçar a utilidade deste procedimento em pacientes com Imunodeficiência Comum Variável.

Observando dados recentes da literatura, verificamos que há um interesse crescente na identificação dos subtipos de LB em pacientes com ICV, porém poucos trabalhos avaliaram a cinética destas células frente à presença de antígenos protéicos e polissacarídicos.

No trabalho realizado pelo nosso grupo (Marinho, 2012), comprovamos eficácia clinica da vacinação contra Influenza, H1N1 e $S$. pneumoniae em pacientes com ICV e este achado determinou a realização deste trabalho, onde o estudo detalhado da cinética das subpopulações de LB, assim como a capacidade de produção de anticorpos específicos nos diferentes tempos após a vacinação podem nos indicar o tipo e duração da resposta especifica a estes antígenos. 
2. OBJETIVOS 


\subsection{Objetivo Principal}

Avaliar o perfil das subpopulações de linfócitos $B$ de pacientes com Imunodeficiência Comum Variável, acompanhados no ambulatório de Imunodeficiências Primárias do Serviço de Imunologia Clínica e Alergia do HCFMUSP antes e após a vacinação com antígenos protéicos e polissacarídicos.

\subsection{Objetivos Específicos}

- Avaliar a capacidade de produção de anticorpos específicos pré e pós vacinação contra S. pneumoniae, Influenza sazonal e Influenza H1N1.

- Determinar as características fenotípicas das subpopulações de LB antes e após vacinação contra a vacina de Influenza.

- Identificar o papel dos LB sobre a diminuição do número de infecções após a administração das vacinas. 


\section{CASUÍSTICA E MÉTODOS}




\subsection{Casuística}

Os pacientes portadores de Imunodeficiência Comum Variável participantes deste estudo fazem parte de uma coorte acompanhada no ambulatório de Imunodeficiências Primárias do Serviço de Imunologia Clínica e Alergia do HC-FMUSP.

Os critérios de inclusão utilizados neste estudo foram: paciente com diagnóstico de ICV, segundo os critérios da Organização Mundial de Saúde (OMS, 1997), Grupo Panamericano de Imunodeficiências Primárias (PAGID) e Sociedade Européia de Imunodeficiências (ESID) e idade superior a 18 anos (Conley et al.,1999).

Os critérios de exclusão utilizados foram: pacientes com doença maligna em tratamento, gestantes, pacientes com imunossupressão grave que contraindicasse a administração das vacinas e pacientes com/ou sob tratamento de infecções no dia da coleta.

No total foram incluídos no estudo 35 pacientes e 16 controles saudáveis, com idade variando entre 28 e 65 anos para os pacientes e 21 e 58 anos para os controles. A seguir a figura 4 descreve a distribuição dos pacientes de acordo com as vacinas recebidas

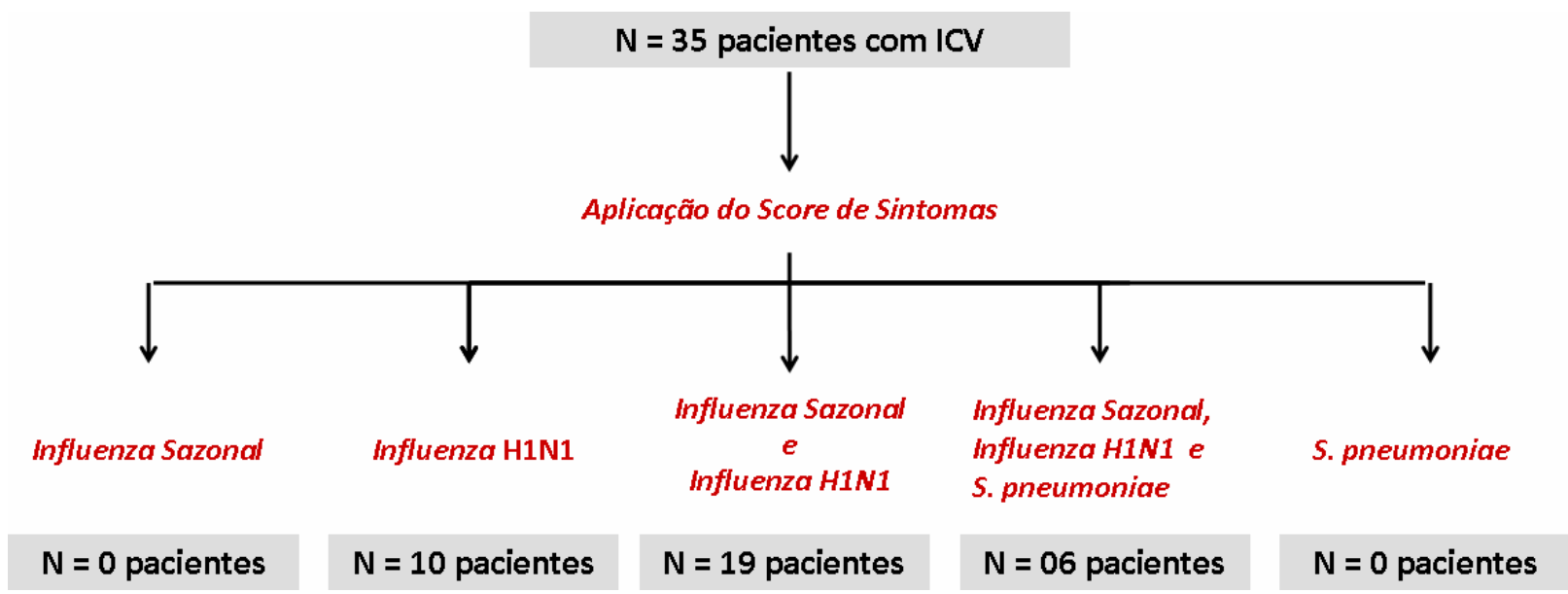

Figura 4: Distribuição dos Pacientes Participantes do Estudo.

O trabalho foi aprovado pelo comite de ética do HC-FMUSP ( ${ }^{\mathrm{o}}$ : 0460/06 ). Todos os indivíduos participantes do estudo foram esclarecidos quanto à natureza e a finalidade do trabalho e convidados a assinar o termo de consentimento livre e esclarecido (anexos 1 e 2).

Tanto os pacientes quanto os controles foram orientados a procurar o Centro de Imunizações do Hospital das Clínicas, onde foram administradas as vacinas anti- 
pneumocócica (Pneumovax 23), anti-Influenza H1N1 e anti-Influenza sazonal por via intramuscular, no mesmo dia. No caso dos pacientes, as vacinas foram administradas 15 dias após a infusão de gamaglobulina.

Foram colhidos $40 \mathrm{~mL}$ de sangue em cada amostra, sendo $10 \mathrm{~mL}$ em tubo seco (sem aditivos) e $30 \mathrm{~mL}$ em tubo heparinizado.

As coletas subsequentes foram realizadas nos tempos de 1, 3 e 6 meses após a vacinação, sempre antes da administração de gamaglobulina endovenosa no caso dos pacientes.

\subsection{Métodos}

\subsubsection{Formulação das Vacinas}

A vacina para Influenza sazonal utilizada foi a vacina trivalente, onde cada cepa apresentou a concentração de $15 \mu \mathrm{g}$ de hemaglutinina. Esta vacina foi formulada no Instituto Butantan, sendo composta pelo vírus inativado e fragmentado, o qual foi propagado em ovos e não apresentou o uso de adjuvantes. As cepas que compuseram a vacina foram: A California/ A Victoria/ A Brisbane.

Em relação a vacina para $\mathrm{H} 1 \mathrm{~N} 1$, esta também foi formulada pelo Instituto Butantan e foi composta de $15 \mu \mathrm{g}$ da cepa A Califórnia H1N1, também propagado em ovos e sem o uso de adjuvantes.

Por fim, a vacina pneumo23, composta dos polissacarídeos encapsulados dos sorotipos: 1, 2, 3, 4, 5, 6B, 7F, 8, 9N, 9V, 10A, 11A, 12F, 14, 15B, 17F, 18C, 19A, 19F, $20,22 \mathrm{~F}, 23 \mathrm{~F}$ e $33 \mathrm{~F}$, sendo que cada sorotipo apresentou a concentração de $0,025 \mathrm{~g}$.

Os lotes das vacinas administradas foram: Influenza sazonal (Lote: VA349400); Influenza H1N1 (Lotes: A80CA184-A; 107.058P1) e S. pneumoniae (Lotes: TO 234.1; NR 5600; NN 14220; NL 15710; P1418.50; YO 237.1).

Não foram observadas reações adversas para as três vacinas tanto no grupo dos pacientes quanto nos controles. 


\subsubsection{Dados Epidemiológicos e Clínicos dos Pacientes}

A avaliação dos dados epidemiológicos foi realizada por meio da análise dos prontuários e entrevista dos pacientes. Foram observadas as principais manifestações apresentadas pelos pacientes, sendo elas: infecções, bronquiectasias, esplenomegalia, linfadenopatia, granulomatose, autoimunidade, doenças malignas e atopia.

Em relação à avaliação clínica, os pacientes foram interrogados sobre o número e gravidade das infecções por meio de um score de sintomas, o qual foi adaptado de um score já validado na literatura (Yarmohammadi et al., 2008).

O score foi aplicado em três fases: antes do início do tratamento padrão, previamente e após a vacinação. Simultaneamente à aplicação dos scores também foi realizada a revisão do prontuário médico.

A pontuação do score aplicado antes do início do tratamento padrão (reposição de imunoglobulinas) foi feita retrospectivamente por meio da entrevista com o paciente e a revisão do prontuário no período de 1 ano antes do início da reposição de imunoglobulinas. Para as outras duas fases o score de sintomas foi aplicado no período de 1 ano antes dos pacientes já sob tratamento padrão receberem as vacinas e no período de 1 ano após a administração das mesmas.

Os parâmetros avaliados foram: amigdalites, sinusites, otites, pneumonias, infecções das vias aéreas superiores (IVAS), antibiótico terapêutico (ATB), internações e bronquiectasias. A tabela 4 descreve o score de sintomas e a pontuação aplicada para cada um dos parâmetros avaliados e os anexos 3, 4 e 5 os resultados para cada paciente nos 3 períodos avaliados.

Tabela 4: Score de Sintomas.

\begin{tabular}{|l|l|l|l|l|l|c|}
\hline \multicolumn{7}{|c|}{ SCORE DE SINTOMAS } \\
\hline & \multicolumn{1}{|c|}{$\mathbf{0}$} & $\mathbf{1}$ & $\mathbf{2}$ & $\mathbf{3}$ & $\mathbf{4}$ & $\mathbf{5}$ \\
\hline Amigdalites & Nenhuma & 1 & 2 & 3 & 4 & 5 ou mais \\
\hline Sinusites & Nenhuma & 1 & 2 & 3 & 4 & 5 ou mais \\
\hline Otites & Nenhuma & 1 & 2 & 3 & 4 & 5 ou mais \\
\hline Pneumonias & Nenhuma & 1 & 2 & 3 & 4 & 5 ou mais \\
\hline Infecções das Vias Aéreas Superiores & Nenhuma & 1 & 2 & 3 & 4 & $>3$ \\
\hline ATB & Não & 1 & 2 & 3 & 4 & 5 ou mais \\
\hline Internações & Nenhuma & 1 & 2 & 3 & 4 & 5 ou mais \\
\hline Bronquiectasias & Não & & & & & Sim \\
\hline
\end{tabular}

Modificado de Yarmohammadi et al., 2008. Amigdalite; Sinusite, Otites; Pneumonias; IVAS: infecções das vias aéreas superiores; ATB: antibiótico terapêutico; Internações; Bronquiectasias. 


\subsubsection{Determinação dos Níveis Séricos de Imunoglobulinas}

O nível sérico da imunoglobulina $\mathrm{G}$ nos pacientes com ICV foi mensurado antes da reposição mensal de imunoglobulinas, pelo método de nefelometria, no Laboratório Central do HC-FMUSP.

\subsubsection{Determinação de Anticorpos Específicos para Influenza}

A avaliação da produção de anticorpos específicos para os sorotipos A e B de Influenza foi realizada por meio dos kits comerciais Ridascreen A (lote: 13361C) e Ridascreen B (lote: 12031C) da empresa r-biopharm. Para este ensaio foram utilizados os soros de 13 pacientes, 16 controles e uma alíquota de imunoglobulina a qual os pacientes fizeram o uso durante a realização das coletas.

Neste ensaio, primeiramente, $10 \mu \mathrm{L}$ das amostras de cada soro foram diluídos em $990 \mu \mathrm{L}$ de um tampão de diluição das amostras, composto por $\mathrm{NaCl}$, Thimerosal a $0,01 \%$ e Tween 20 a $0,05 \%$. Posteriormente, foram pipetados $100 \mu \mathrm{L}$ das amostras tratadas com o tampão nas respectivas placas sensibilizadas com os antígenos dos sorotipos A e B do vírus Influenza.

Em seguida foram pipetados $100 \mu \mathrm{L}$ do controle negativo, composto de soro humano diluído em Thimerosal a $0,01 \%$ e Tween 20 a $0,05 \%$ e $100 \mu \mathrm{L}$ do branco da reação, composto apenas do tampão de diluição das amostras. Como controle positivo da reação foram pipetados $100 \mu \mathrm{L}$ de uma solução fornecida pelo kit, o qual também é composta de soro humano diluído em Thimerosal a $0,01 \%$ e Tween 20 a $0,05 \%$.

A placa foi incubada a $37^{\circ} \mathrm{C}$ por 30 minutos e após a incubação, o sobrenadante foi desprezado e a placa foi batida sobre papel absorvente para a remoção dos restos de umidade.

$\mathrm{Na}$ sequência foi realizada a lavagem da placa, onde em cada poço foram pipetados $300 \mu \mathrm{L}$ de solução de lavagem, composta de solução de $\mathrm{NaCl} 3$ x, 0,01\% de Bronidox-L e $0,5 \%$ de Tween 20. Este procedimento foi realizado 4 vezes.

Após a lavagem, o sobrenadante foi desprezado e em cada poço foi pipetado $100 \mu \mathrm{L}$ do conjugado, composto de IgG de coelho anti-IgG humano e peroxidase e a placa foi incubada por 30 minutos a $37^{\circ} \mathrm{C}$. 
O sobrenadante foi desprezado e foi realizada a lavagem da placa novamente, sendo este procedimento repetido 4 vezes e logo em seguida foram adicionados $100 \mu \mathrm{L}$ do substrato fornecido pelo kit, composto de $\mathrm{H}_{2} \mathrm{O}_{2}$ e tetrametilbenzidina.

Novamente foi realizada a incubação a $37^{\circ} \mathrm{C}$ por 30 minutos e logo após foi adicionado em todos os poços $100 \mu \mathrm{L}$ da solução bloqueadora, composta de ácido sulfúrico $1 \mathrm{~N}$.

A placa foi cuidadosamente homogeneizada e foi realizada a leitura em espectrofotômetro, medindo as absorbâncias obtidas no comprimento de onda de 450 nm. A análise foi feita após a identificação do valor médio obtido para o controle padrão e sua correlação com a respectiva densidade óptica, fornecida em uma tabela pelo kit, o qual foi de 0,82 para o sorotipo A e de 0,60 para o sorotipo B.

\subsubsection{Determinação de Anticorpos Específicos para H1N1}

Para o ensaio de determinação de anticorpos IgG específicos para H1N1, foram testados os soros de 20 pacientes e 16 controles e a metodologia utilizada foi o ensaio de hemaglutinação indireta.

Primeiramente as amostras testadas foram tratadas para a remoção de partículas que pudessem gerar uma ligação inespecífica quando na reação com o antígeno hemaglutinina de H1N1. Para isso $50 \mu \mathrm{L}$ de cada uma das amostras foram diluídas com $150 \mu \mathrm{L}$ de um pool de marcadores inespecíficos, denominado RDE (Receptor Destroying Enzyme) o qual foi fornecido pela empresa Denka Seiken (lote: 299061) e foram incubadas à $37^{\circ} \mathrm{C}$ por 22 horas.

No dia seguinte, as amostras foram incubadas a $56^{\circ} \mathrm{C}$ por 10 minutos para inativação do RDE e logo em seguida foram adicionados $300 \mu 1$ de solução fisiológica em cada um dos tubos contendo as amostras.

Uma placa de 96 poços em fundo $U$ foi denominada como amostras de soro e nela foram pipetados $25 \mu 1$ de PBS em todos os poços, exceto na primeira fileira, onde foram pipetados $25 \mu \mathrm{l}$ de soro previamente preparado e a partir da segunda fileira foi realizada uma diluição seriada com $25 \mu 1$ de soro em cada poço.

Em uma segunda placa de 96 poços em fundo $U$ foram pipetados $50 \mu 1$ de PBS em todos os poços, exceto na primeira fileira onde foram pipetados $100 \mu 1$ do antígeno hemaglutinina de Influenza $\mathrm{H} 1 \mathrm{~N} 1$ e esta placa foi identificada como controle do 
antígeno. $\mathrm{O}$ antígeno hemaglutinina do vírus Influenza - $\mathrm{H} 1 \mathrm{~N} 1$ foi fornecido pela empresa Influenza Reagent Resourch (identificação: FR187, lote: 58702795), sendo composto de $1 \mathrm{~mL}$ do peptídeo hemaglutinina do vírus diluído em PBS e no momento do seu uso deve ser diluído em mais $9 \mathrm{~mL}$ de PBS, mantido no gelo e homogeneizado vigorosamente. A partir da segunda fileira da placa também foi realizada uma diluição seriada, onde foram pipetados $50 \mu 1$ do antígeno em cada poço.

Para a placa do controle positivo da reação foram pipetados $25 \mu 1$ de PBS em todos os poços exceto na primeira fileira, onde foram pipetados $25 \mu \mathrm{l}$ do soro positivo fornecido pela empresa Influenza Reagent Resourch junto com o antígeno hemaglutinina do Influenza- H1N1. A partir da segunda fileira foi realizada a diluição seriada, onde foram pipetados $25 \mu 1$ do soro positivo em cada poço.

Em seguida foram adicionados $25 \mu$ d do antígeno hemaglutinina de Influenza - H1N1 em todos os poços das placas das amostras e controle positivo da reação e foi realizada a incubação por 15 minutos a temperatura ambiente.

Após a incubação foram pipetados delicadamente em pipeta de vidro $50 \mu \mathrm{l}$ de hemácias de galinha, previamente tratadas no dia anterior em todas as placas. As hemácias de galinha devem ser coletadas 1 dia antes de serem utilizadas e mantidas em geladeira até o dia seguinte e o seu preparo é realizado por meio de 2 lavagens com PBS e duas centrifugações a $290 \mathrm{xg}$ por 5 minutos e $453 \mathrm{xg}$ por 10 minutos simultaneamente. Deve ser realizada uma diluição de 1/10 em PBS e no momento do seu uso uma nova diluição deve ser feita, para uso na reação a uma diluição de 1/20.

As placas foram incubadas por 30 minutos a temperatura ambiente e após a incubação, quando na presença de anticorpos IgG específicos para $\mathrm{H} 1 \mathrm{~N} 1$, estes se ligam ao antígeno hemaglutinina do vírus e as hemácias permanecem preservadas, sendo possível observar a presença de um botão de hemácias no poços das placas, porém na ausência de anticorpos específicos, as células sofrem lise celular, devido a ligação da hemaglutinina do vírus ao receptor presente na membrana celular das hemácias.

As placas foram inclinadas em um ângulo de $45^{\circ}$ para verificação da formação de uma gota nos poços onde havia a presença do botão celular, sendo a amostra considerada positiva a partir da diluição de 1/40. 


\subsubsection{Determinação de Anticorpos Específicos para S. pneumoniae}

O ensaio para a determinação de anticorpos específicos para S. pneumoniae foi realizado em 4 pacientes e foram pesquisados anticorpos específicos para 6 sorotipos: 1/6B/5/9/14/18.

No primeiro dia da reação, seis tubos tipo Falcon foram identificados para cada um dos sorotipos testados e logo em seguida foram pipetados $11 \mu \mathrm{l}$ dos sorotipos em seu respectivo tubo e $11 \mathrm{~mL}$ de PBS, tendo esta solução a concentração final de $10 \mu \mathrm{g} / \mathrm{mL}$. Em seguida, seis placas de 96 poços foram identificadas e $100 \mu 1$ de cada sorotipo foram pipetados em todos os poços de sua respectiva placa e foi realizada a incubação a $37^{\circ} \mathrm{C}$ por cinco horas. Posteriormente à incubação, todas as placas foram mantidas na geladeira a $4^{\circ} \mathrm{C}$.

No dia seguinte, foram identificados tubos tipo Falcon que receberam cada uma das amostras testadas e em cada um deles foi pipetado $30 \mu \mathrm{l}$ do soro e $300 \mu \mathrm{l}$ do tampão A, o qual foi composto por Poly C, sorotipo 22F e tampão BSA-PBS Tween (Apêndice).

Em seguida foi preparada a curva controle e o pool pneumo do ensaio. A curva controle foi composta de um pool de soros de controles sadios que não haviam sido vacinados para a vacina do $S$. pneumoniae, onde em um tubo tipo Falcon foram pipetados $30 \mu \mathrm{l}$ do pool de soros e na sequência $300 \mu \mathrm{l}$ do tampão $\mathrm{B}$, composto por BSA-PBS Tween e Poly C (Apêndice) e o pool pneumo foi preparado através da adição de $30 \mu 1$ do pool de soros de controles sabidamente vacinados para a vacina contra $S$. pneumoniae e $300 \mu 1$ do tampão B.

As amostras, curvas controle e pool pneumo foram incubadas em temperatura ambiente por 1 hora e após a incubação foi realizada a diluição final. Para as amostras, foram pipetados 1,3 mL do tampão BSA-PBS (Apêndice) diretamente nos tubos de cada amostra de soro. Para as curvas controle e padrão foram pipetados $70 \mu \mathrm{l}$ do pool dos seus respectivos soros previamente incubados em 1,35 $\mathrm{mL}$ de tampão BSA - PBS Tween.

Após a preparação das amostras e curvas, as placas sensibilizadas no dia anterior foram retiradas da geladeira, lavadas em um tampão de lavagem contendo PBS 20x, Tween $20 \%$ e água destilada (Apêndice), o sobrenadante foi desprezado e as placas foram batidas sobre papel absorvente para a remoção de restos de umidade, sendo este procedimento repetido 3 vezes. 
Em seguida foram pipetados $50 \mu 1$ do tampão BSA - PBS Tween em todos os poços de todas as placas, exceto nas duas primeiras colunas. Nas posições A1 e A2 de todas as placas foram pipetados $100 \mu \mathrm{l}$ do pool pneumo e a partir da segunda linha, foram pipetados $50 \mu \mathrm{l}$ do pool pneumo da primeira fileira, sendo realizada uma diluição seriada com 7 diluições, já as posições $\mathrm{H} 1$ e H2 foram utilizadas para definição do branco da reação. No restante da placa, foram pipetados $100 \mu \mathrm{l}$ das amostras e também a curva controle, onde novamente foi realizada uma diluição seriada com 4 diluições. Em todas as placas foram realizadas duplicatas para todas as amostras e curvas.

As placas foram cobertas com papel filme e incubadas em temperatura ambiente por 2 horas e após a incubação novamente foi realizado o procedimento de lavagem.

Nesta etapa do ensaio, foram adicionados $50 \mu \mathrm{l}$ do conjugado em todos os poços, sendo este composto de $\operatorname{IgG}$ anti-IgG humana marcada com peroxidase diluída em tampão BSA-PBS Tween (Apêndice) e novamente foi realizada a incubação das placas em temperatura ambiente por 2 horas.

Após a incubação, todas as placas passaram pelo processo de lavagem e na sequência foram pipetados em todos os poços $100 \mu \mathrm{l}$ do substrato, composto por OPD na concentração de $30 \mathrm{mg} / \mathrm{mL}$ diluídos em um tampão de citrato-fosfato (Apêndice). As placas foram incubadas no escuro por 30 minutos e em temperatura ambiente e a reação foi parada após a adição de $50 \mu \mathrm{L}$ de ácido sulfúrico $\left(\mathrm{H}_{2} \mathrm{SO}_{4}\right)$ 2,5N (Apêndice) em todos os poços.

A leitura das placas foi feita por meio de um espectrofotômetro, medindo as absorbâncias obtidas no comprimento de onda de $492 \mathrm{~nm}$ e as amostras foram consideradas positivas quando pelo menos quatro sorotipos apresentaram concentração acima de $1,3 \mu \mathrm{g} / \mathrm{mL}$.

\subsubsection{Obtenção de Células Mononucleares de Sangue Periférico}

A separação de células mononucleares de sangue periférico (CMSP) foi realizada em cabine de segurança biológica nível 2, o qual foi esterilizada por 15 minutos através da radiação de luz ultravioleta.

Após este procedimento inicial, as amostras de sangue coletadas foram diluídas em solução tampão de salina estéril em 2 tubos tipo Falcon de 50 mL e logo após a delicada 
homogeneização, cuidadosamente foram transferidas para outros 2 tubos tipos Falcon contendo $10 \mathrm{~mL}$ de solução Ficoll-Paque ${ }^{\mathrm{TM}}$ PLUS (Amersham Biosciences).

As amostras foram centrifugadas por 30 minutos a $300 \mathrm{xg}$ em temperatura de $20^{\circ} \mathrm{C} \mathrm{e}$ após a centrifugação foi possível verificar a formação da nuvem de células mononucleares, localizadas na interface do Ficoll-Hypaque. Com o auxílio de uma pipeta, as células mononucleares foram coletadas e transferidas para outro tubo tipo falcon de $50 \mathrm{~mL}$, o qual foi completado o volume com a solução de salina estéril.

Em seguida as amostras foram centrifugadas por 10 minutos a $250 \mathrm{xg}$ em temperatura de $20^{\circ} \mathrm{C}$, onde após a centrifugação foi possível verificar a presença de um botão celular.

O sobrenadante foi desprezado e as células foram homogeneizadas até se desprenderem do tubo. O volume foi completado até a marca de $50 \mathrm{~mL}$ com solução salina estéril novamente e os tubos foram centrifugados por 10 minutos a $250 \mathrm{xg} \mathrm{em}$ temperatura de $20^{\circ} \mathrm{C}$.

Novamente foi verificada a formação do botão celular, desprezado o sobrenadante e as células foram homogeneizadas com $10 \mathrm{~mL}$ de meio de cultura $\mathrm{R} 10$, composto por: $500 \mathrm{~mL}$ de meio de cultura RPMI $1640\left(\mathrm{GIBCO}^{\mathrm{TM}}\right)$; $50 \mathrm{~mL}$ de soro fetal bovino $\left(\mathrm{GIBCO}^{\mathrm{TM}}\right)$ inativado pelo calor; $5 \mathrm{~mL}$ de solução tampão HEPES $1 \mathrm{M}\left(\mathrm{GIBCO}^{\mathrm{TM}}\right) ; 5$ $\mathrm{mL}$ de L-Glutamina $200 \mathrm{mM}\left(\mathrm{GIBCO}^{\mathrm{TM}}\right)$; solução piruvato $100 \mathrm{mM}\left(\mathrm{GIBCO}^{\mathrm{TM}}\right) ; 5 \mathrm{~mL}$ de penicilina e estreptomicina $\left(\mathrm{GIBCO}^{\mathrm{TM}}\right)$ e $0,5 \mathrm{~mL}$ de mercaptoetanol $\left(\mathrm{GIBCO}^{\mathrm{TM}}\right)$.

As amostras foram centrifugadas por 10 minutos a $250 \mathrm{xg}$ em temperatura de $20^{\circ} \mathrm{C} \mathrm{e}$ após o sobrenadante ser desprezado, o botão celular foi ressuspendido em $10 \mathrm{~mL}$ de meio de cultura R10 para que pudesse ser feita a contagem das células.

A viabilidade celular foi definida através da utilização do corante azul de tripan $1 \%$ $\left(\right.$ Sigma $\left.^{\circledR}\right)$ na diluição $1 / 10$ e a contagem foi realizada em microscópio óptico em aumento de 400 vezes. A contagem foi realizada em dois quadrantes laterais da câmara de neubauer, onde foram desconsideradas as células mortas, as quais apareceram coradas de azul.

O cálculo da concentração celular foi feito através do número médio de células nos dois quadrantes $\mathrm{x}$ valor da diluição do corante azul de tripan $\mathrm{x}$ volume ressuspendido em meio RPMI x $10^{4}$ (valor de correção da câmara de neubauer) e a concentração celular foi acertada para $1 \times 10^{6}$ células por poço. 


\subsubsection{Cultura de Linfócitos}

Após a separação de CMSP e definida a concentração celular para $1 \times 10^{6}$ células por poço foram pipetados $100 \mu \mathrm{L}$ de células e igual volume de meio de cultura R10 para a condição basal, onde foi realizada a duplicata. Também foram adicionados mais 3 poços contendo apenas células em meio de cultura R10, o qual um deles foi utilizado para o ajuste da população de linfócitos no momento da aquisição das amostras no citômetro de fluxo e os outros dois para auxiliar a identificação das subpopulações de linfócitos B durante a análise pelo programa FlowJo.

Como controles positivos do ensaio foram utilizados dois mitógenos, o primeiro foi o mitógeno pokeweed (PWM) na concentração de $80 \mathrm{ng} / \mathrm{mL}$, devido ao fato dele ser capaz de induzir uma proliferação inespecífica de linfócitos B e o segundo foi o peptídeo hemaglutinina do vírus Influenza $\left(\right.$ Sigma $\left.^{\circledR}\right)$ na concentração de $2,5 \mu \mathrm{g} / \mathrm{mL}$, sendo este antígeno composto pelo peptídeo sintético da região conservada de hemaglutinina dos vírus Influenza diluídos em PBS. Para todos os estímulos foram realizadas duplicatas.

Por fim, a avaliação da resposta antígeno específica à vacina de Influenza foi realizada através da utilização de uma alíquota de lisado viral fornecida pelo Instituto Butantan. Esta alíquota foi composta de lisado viral das cepas de Influenza utilizadas na vacina administrada no ano de 2012, período o qual foram realizadas as coletas, diluídas em PBS e após sua quantificação protéica e titulação, a concentração de $30 \mathrm{ng} / \mathrm{mL}$ foi utilizada no ensaio de cultura, sendo também realizadas duplicatas.

As placas foram mantidas em cultura por seis dias em incubação em estufa a $5 \%$ de $\mathrm{CO}_{2}$, a $37^{\circ} \mathrm{C}$ e após a incubação, os sobrenadantes foram coletados e foi realizada a marcação por citometria de fluxo para verificar a frequência das subpopulações de linfócitos B.

\subsubsection{Imunofenotipagem para Identificação de Subpopulações de Linfócitos B}

Após seis dias em cultura, as placas foram retiradas da incubadora e foram centrifugadas a $250 \mathrm{xg}$ por 10 minutos em temperatura em torno de $20^{\circ} \mathrm{C}$ para os sobrenadantes serem coletados. Na sequência, as células foram ressuspendidas em 100 $\mu \mathrm{L}$ de PBS e a placa foi centrifugada novamente a $250 \mathrm{xg}$ por 10 minutos em 
temperatura de $20^{\circ} \mathrm{C}$ para lavagem celular, o sobrenadante foi desprezado e o botão celular de cada poço foi ressuspendido em $100 \mu \mathrm{L}$ de PBS.

Em seguida foi realizada a marcação de superfície para as subpopulações de linfócitos B. Esta marcação nos permitiu a identificação de quatro subtipos: LB naive; LB de zona marginal (MZB); LB de memória com troca de isotipo (SMB) e plasmoblastos (PBL). Para iniciar a marcação foram adicionados os volumes dos anticorpos monoclonais previamente titulados: CD19 (APC - Cy7) - 0,5 $\mu \mathrm{L}$; CD27 (PECy7) - 0,5 $\mu \mathrm{L} ; \operatorname{IgD}($ FITC) - 0,5 $\mu \mathrm{L} ;$ CD38 (ALEXA 700) - 1,5 $\mu \mathrm{L}$; IgM (PerCP) $0,5 \mu \mathrm{L}$ e marcador de viabilidade Live/Dead (Texas Red) - 0,6 $\mu \mathrm{L}$. A tabela abaixo descreve os anticorpos utilizados.

Tabela 5: Anticorpos Utilizados para Marcação de Superfície Celular dos Subtipos de LB.

\begin{tabular}{cccc}
\hline Anticorpo & Fluorocromo & Marca & Clone \\
\hline CD19 & APC - Cy7 & BD & HIB19 \\
CD27 & PE - Cy7 & BD & M-T271 \\
IgD & FITC & BD & IA6-2 \\
CD38 & ALEXA 700 & BD & HIT2 \\
IgM & PerCP & BD & G20-127 \\
Live/Dead & Texas Red & Invitrogen & L23102 \\
\hline
\end{tabular}

APC - Cy7: aloficocianina Cy-chrome 7 ; PE - Cy7: ficoeritrina Cy-chrome 7; FITC: isotiocianato de fluoresceín; APC: aloficocianina; PerCP: peridinin chlorophyll protein; PE: ficoeritrina. BD: BD Biosciences, San Diego, CA, EUA.

Após a adição dos anticorpos monoclonais, as células permaneceram sob incubação por 30 minutos no escuro e na sequência ao término da incubação, as placas foram centrifugadas a $250 \mathrm{xg}$ por 10 minutos em temperatura de $20^{\circ} \mathrm{C}$, o sobrenadante foi desprezado e o volume de cada poço foi completado com $100 \mu \mathrm{L}$ de PBS, sendo este procedimento de lavagem repetido 2 vezes.

Finalizando a técnica de imunofenotipagem de superfície, em cada poço das placas foram pipetados $500 \mu \mathrm{L}$ de Paraformaldeído a 1\% (PFA 1\%), o qual foi composto por 9 $\mathrm{mL}$ de PBS (1x) e $1 \mathrm{ml}$ de Paraformaldeído (10x) $\left(\right.$ Sigma $\left.^{\circledR}\right)$, visando promover a fixação dos anticorpos monoclonais às células.

As células foram transferidas, respectivamente para microtubos (Fisherbrand ${ }^{\circledR}$, Houston, TX) previamente identificados e permaneceram armazenadas sob-refrigeração 
até o momento da leitura no citômetro de fluxo, modelo Canto (BD), disponível no LIM60, dotado de detectores capazes de adquirir e analisar eventos com até 8 cores.

A aquisição das amostras foi feita adquirindo-se 300.000 eventos na região de linfócitos e os resultados foram analisados no programa FLOWJO versão 8.7.1.

Primeiramente, em cada amostra analisada foi definida a região denominada Time, permitindo a identificação da região onde não houve oscilação do laser vermelho. Em uma nova janela de aquisição, utilizando os parâmetros de FSC-A (tamanho em área) versus FSC-H (tamanho em altura) foram identificadas as células que passaram apenas uma vez em frente ao laser, sendo denominadas singlets.

Na sequência foi realizada a identificação da população de linfócitos totais, seguida da identificação das células viáveis, por meio da utilização do kit Live/Dead. A população de linfócitos B foi determinada através da expressão da molécula CD19, sendo definida por serem $\mathrm{CD} 19^{+}$. A figura 5 demonstra a estratégia de análise para identificação e definição dos linfócitos B. 

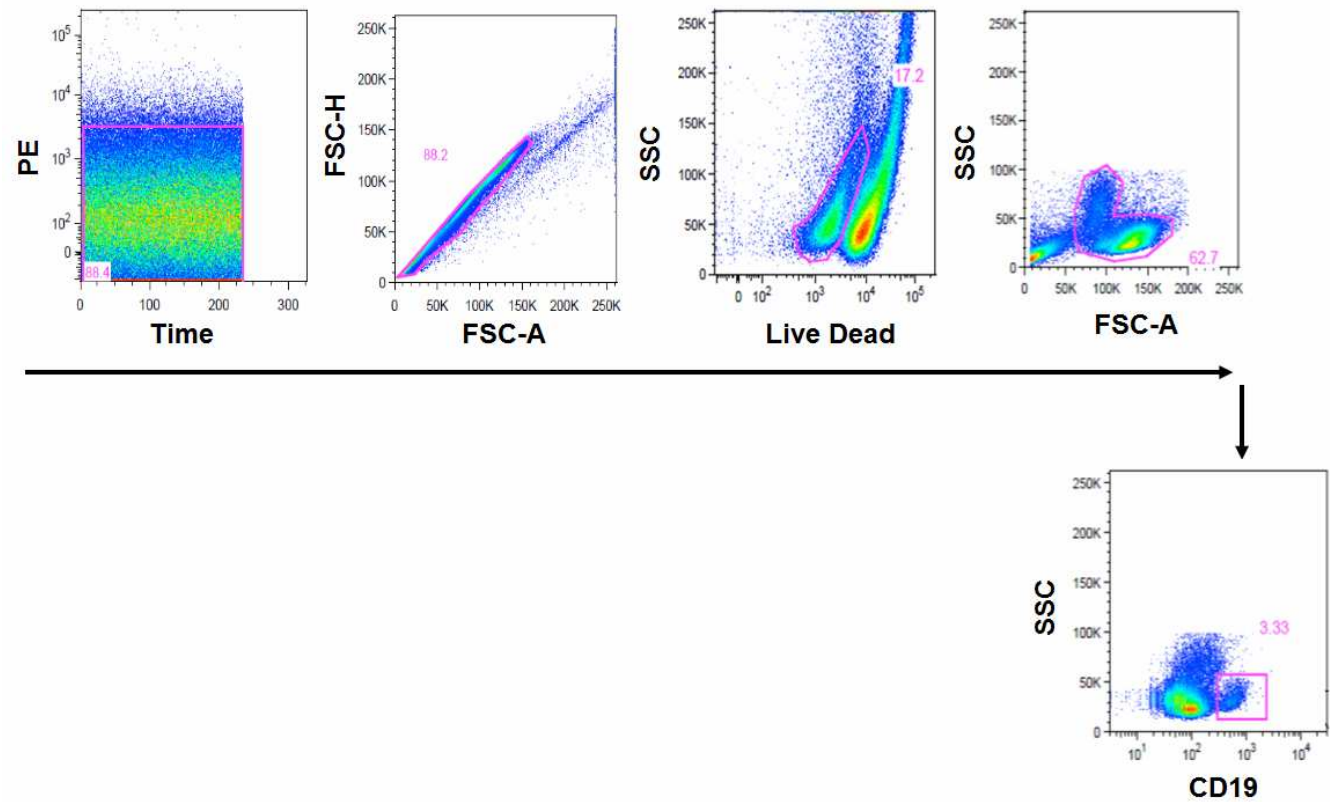

Figura 5: Estratégia de Análise para Identificação e Definição de Linfócitos B. Primeiramente foi feita uma janela de aquisição na região denominada Time, caracterizando a não oscilação do laser. $\mathrm{Na}$ sequência foram identificadas as células que passaram apenas uma vez em frente ao laser, denominados singlets, determinadas através da comparação entre tamanho em relação a altura (FSC-H) e em relação a área (FSC-A). Nas janelas de aquisição seguintes foram feitas a identificação de células vivas, denominadas de Live Dead e a identificação da população de linfócitos totais. Posteriormente foi feita a identificação dos linfócitos B, sendo identificados por serem CD19 ${ }^{+}$.

Primeiramente foram analisados os tubos denominados por FMO (do inglês "fluorescence minus one"). Para estas marcações, foram utilizadas amostras controles, oriundas de indivíduos saudáveis, onde, através do emprego de todos os anticorpos monoclonais menos um, é possível a identificação com precisão da população celular de interesse.

Em nosso caso foram utilizados $F M O$ para os marcadores fenotípicos $\operatorname{IgD}$ e $\operatorname{IgM}$ respectivamente, os quais permitiram a identificação correta das subpopulações de LB naive, LB de zona marginal, LB de memória com troca de isotipo e plasmoblastos. A figura 6 descreve a estratégia de análise através do FMO. 


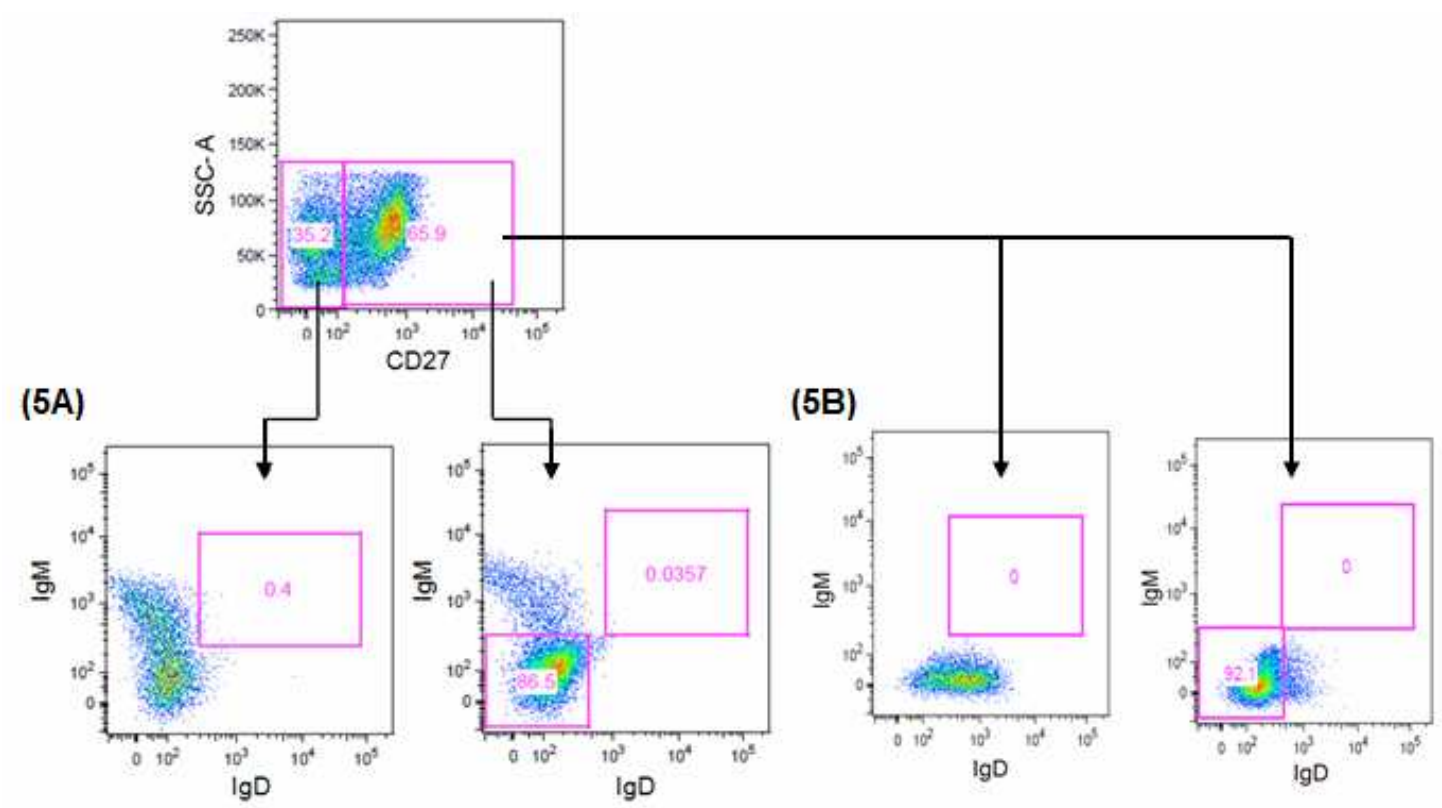

Figura 6: Estratégia de Análise Através do FMO. Após a identificação da população de LB foi feita a análise dos FMOs para IgD (5a) e IgM (5b), onde as células foram marcadas com CD19 (APC-Cy7), CD27 (PE-Cy7), distinguindo assim a linha de corte para IgD (FITC) e IgM (PercP) respectivamente.

Após a análise dos FMOs e, portanto, definindo as linhas de corte para $\operatorname{IgD}$ e $\operatorname{IgM}$, foram feitas as análises das amostras de pacientes e controles. Na figura 7, é possível identificar as subpopulações de $\mathrm{LB}$ naive $\left(\mathrm{CD} 19^{+} \mathrm{CD} 27^{-} \operatorname{IgD}{ }^{+} \operatorname{IgM}^{+}\right)$; $\mathrm{LB}$ de zona marginal $\left(\mathrm{CD}_{19} \mathrm{CD}^{+} 7^{+} \mathrm{IgD}^{+} \operatorname{IgM}^{+}\right)$; $\mathrm{LB}$ de memória com troca de isotipo $\left(\mathrm{CD}_{19}{ }^{+} \mathrm{CD} 27^{+} \operatorname{IgD}^{-} \operatorname{IgM}^{-}\right)$e plasmoblastos $\left(\mathrm{CD} 19^{+} \mathrm{CD} 27^{+} \mathrm{CD}^{+} 8^{+} \operatorname{IgM}^{-}\right)$. 


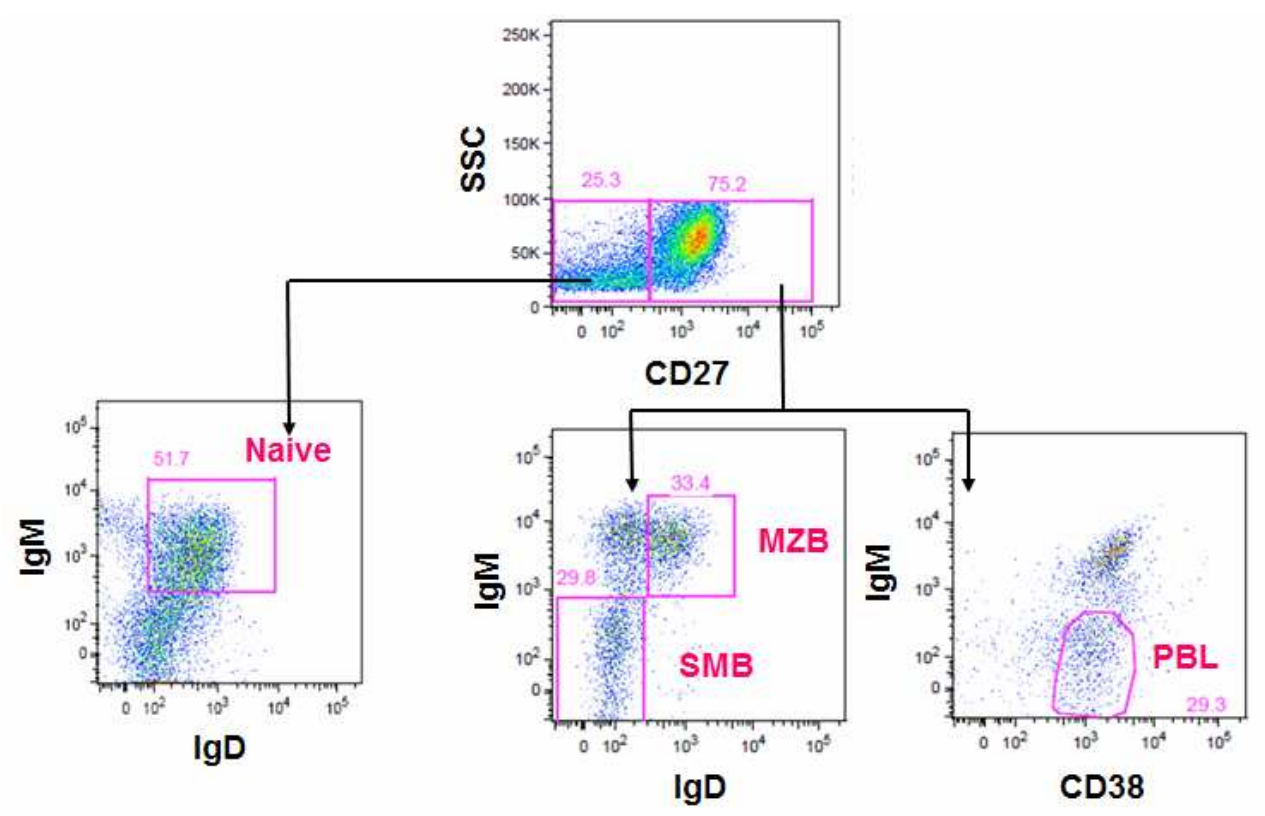

Figura 7: Estratégia de Análise para Identificação e Definição das Subpopulações de Linfócitos B. Após a identificação dos linfócitos $\mathrm{B}$ totais, foram identificadas 4 subpopulações através dos marcadores CD27, IgD, IgM e CD38: naive: $\mathrm{CD}_{19}^{+} \mathrm{CD} 27^{-} \mathrm{IgM}^{+} \operatorname{IgD}^{+}$; zona marginal - MZB $\mathrm{CD}^{+} 9^{+} \mathrm{CD} 27^{+} \operatorname{IgM}^{+} \operatorname{IgD}{ }^{+}$; memória com troca de isotipo - SMB: $\mathrm{CD} 19^{+} \mathrm{CD} 27^{+} \operatorname{IgM} \mathrm{IgD}^{-}$e plasmoblastos - PBL: $\mathrm{CD} 19^{+} \mathrm{CD} 38^{+} \mathrm{CD} 27^{+} \operatorname{IgM}$.

\subsubsection{Classificação dos Pacientes de Acordo com o Tipo de Resposta Após a} Vacinação.

Com os dados da imunofenotipagem de LB pré e pós vacinação foi realizado um modelo de classificação baseado na frequência das subpopulações de LB de memória com troca de isotipo (SMB) e plasmoblastos (PBL), com a finalidade de determinar o padrão de resposta que os pacientes apresentaram após a vacinação.

Como nos pacientes a maior expressão destas duas subpopulações de LB ocorreu no primeiro mês após a vacinação, esta classificação foi baseada na análise da diferença das frequências obtidas após 1 mês da vacinação com o período pré-vacinação, assim os pacientes foram subdivididos em 3 grupos.

No grupo 1 (G1) se encontram os pacientes que apresentaram um padrão de resposta semelhante ao observado no grupo dos controles, onde é possível verificar um aumento na expressão tanto de SMB quanto de PBL. O grupo $2(\mathrm{G} 2)$ foi composto por pacientes que apresentaram apenas um aumento na expressão de SMB e por fim, o grupo 3 (G3) estão os pacientes que não tiveram aumento da expressão de células $\mathrm{B}$ de memória, 
apenas foi observado o aumento na expressão de PBL, indicando assim, uma resposta de baixa duração.

\subsubsection{Análise Estatística}

Os testes estatísticos utilizados foram obtidos através do programa Stata 10.1 (StataCorp. 2007. Stata Statistical Software: Release 10. College Station, TX: StataCorp LP).

Inicialmente o teste Skweness-kurtosis foi realizado para verificar a normalidade dos resultados. A partir deste teste preliminar, os resultados que apresentaram $p>0,05$ foram considerados normais, onde para os resultados não pareados foi realizado o teste $\mathrm{T}$ de Student não pareado bicaudal e para os resultados pareados, o teste $\mathrm{T}$ de Student pareado bicaudal e os resultados foram apresentados por meio da média e seus intervalos de confiança de $95 \%$. Os resultados que apresentaram p $\square 0,05$ no teste Skweness-kurtosis foram considerados não normais e para eles, quando se apresentaram não pareados foi realizado o teste Mann-Whitney ou Kruskal-Wallis, já para os resultados pareados foi utilizado o teste Wilcoxon bicaudal ou o teste de Friedman, estes resultados foram apresentados por meio de mediana e intervalo interquartil.

Por fim para a análise dos resultados que apresentaram variáveis categóricas não pareadas foram realizados os testes de Qui-Quadrado ou teste Exato de Fisher e para os resultados pareados foi realizado o teste McNemar.

Para a avaliação dos dados epidemiológicos, a comparação em relação a idade foi feita através do teste Mann-Whitney, já a análise em relação ao gênero foi feita por meio do teste Qui-Quadrado.

A análise da pontuação total do score de sintomas foi feita através do teste Wilcoxon bicaudal e a avaliação do score total de sintomas de acordo com o número de vacinas que os pacientes receberam foi feita através do teste Kruskal-Wallis.

$\mathrm{O}$ teste $\mathrm{T}$ de Student não pareado bicaudal foi utilizado para a avaliação da concentração sérica de IgG obtidas antes do início da reposição de imunoglobulinas com o período atual, também foi realizada a comparação entre o nível de IgG para os períodos pré, 1 e 3 meses após a vacinação.

O teste Wilcoxon bicaudal também foi utilizado para a avaliação dos níveis de anticorpos do tipo IgG específicos para os sorotipos A e B de Influenza do período pré 
vacina com os diferentes tempos após a vacinação, já a comparação entre os valores obtidos para pacientes e controles foi feita através do teste Kruskal-Wallis. Também foi realizada a comparação em relação a soroproteção para Influenza, por meio do teste Exato de Fisher.

Para a análise da concentração de anticorpos IgG específicos para H1N1 também foi realizada a comparação do período pré vacina com os períodos pós vacinação e a comparação entre os valores obtidos para pacientes e controles, por meio dos testes Wilcoxon bicaudal e Kruskal-Wallis respectivamente. A análise da soroproteção para H1N1 foi feita através do teste Exato de Fischer, assim como a análise para soroconversão.

A avaliação da frequência das subpopulações de linfócitos B para todos os períodos estudados foi feita através do teste Wilcoxon bicaudal, já a comparação entre as frequiências obtidas para os pacientes com os valores observados para o grupo controles foi feita através do teste Mann-Whitney.

A correlação da diferença da expressão no período pós 1 mês com o período pré vacinação entre as subpopulações de LB de memória e plasmoblastos foi obtida por meio do Teste de Spearman.

A diferença estatística foi considerada significativa a partir do valor de $\mathrm{p}<0,05$. 


\subsection{Dados Epidemiológicos e Clínicos}

Foram selecionados 35 pacientes, sendo 16 pacientes homens e 19 mulheres e 16 controles, 5 homens e 11 mulheres. A tabela 6 descreve os dados epidemiológicos dos grupos de pacientes e controles.

Tabela 6: Características Demográficas dos Participantes do Estudo.

\begin{tabular}{l|c|c}
\hline & Controles & ICV \\
\hline Dados Epidemiológicos & $(\mathrm{n}=16)$ & \multicolumn{2}{|c}{$\%(\mathrm{n}=35)$} \\
\hline Gênero M/F & \multicolumn{2}{|c}{$p 5 \%)$} \\
\hline & $31 \% / 69 \%$ & $57,7 \% / 42,3 \%$ \\
\hline Idade (mediana em anos) & \multicolumn{2}{|c}{$p 50$-p75) } \\
Idade de Diagnóstico (mediana em anos) & $30,9(28,5-44)$ & $40(27-65)$ \\
Idade do Início dos Sintomas (mediana em anos ) & - & $33,4(26,1-40,7)$ \\
Retardo do Diagnóstico (mediana em anos) & - & $19(9,5-31,5)$ \\
\hline
\end{tabular}

A análise estatística revelou não haver uma diferença significativa em relação ao gênero tanto no grupo dos pacientes quando nos controles $(\mathrm{p}=0,1)$, assim como em relação a idade ( $\mathrm{p}=0,084$ ), sendo de 30,9 anos para os controles (21 a 58 anos) e 40 anos para os pacientes (27 a 65 anos).

A mediana da idade do início dos sintomas foi de 19 anos (9,5 a 31,5 anos) e em relação à idade do diagnóstico foi verificada média de 33,4 anos (26,1 a 40,7 anos). Portanto a mediana do retardo do diagnóstico foi de 6 anos.

A figura 8 descreve as manifestações clínicas mais comumente observadas nos pacientes com ICV participantes deste trabalho. 


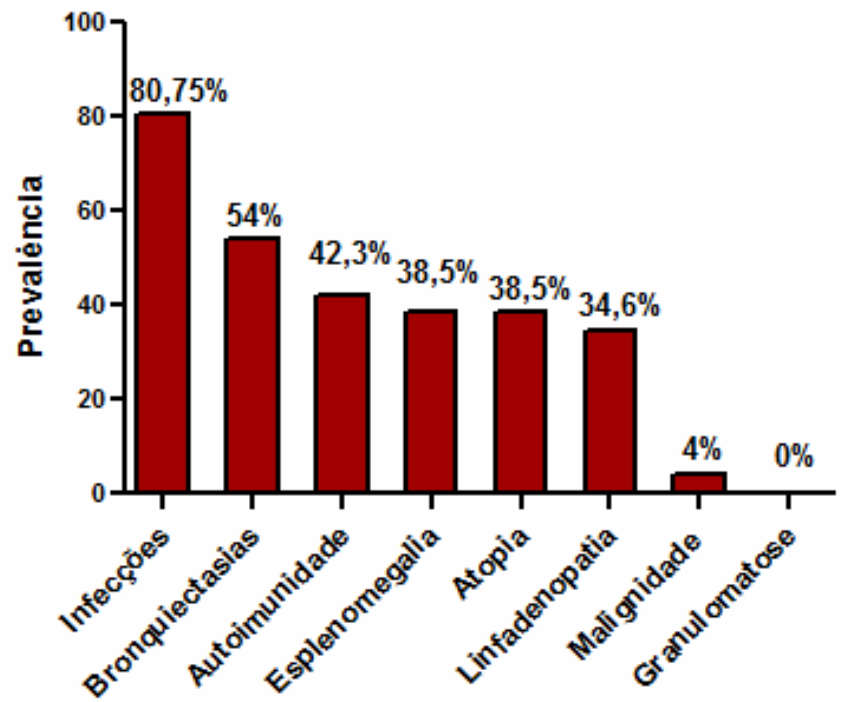

Figura 8: Manifestações Clínicas. Foram consideradas 8 manifestações clínicas: infecções, bronquiectasias, esplenomegalia, linfadenopatia, granulomatose, autoimunidade, malignidade e atopia. Os resultados foram expressos como porcentagem dos pacientes da coorte com a manifestação avaliada.

Os eventos clínicos observados nestes pacientes foram separados em 7 grupos: Infecções Recorrentes, Bronquiectasias, Granulomatose, Manifestações Linfoproliferativas Benignas, Doenças Autoimunes, Malignidade e Atopia, que estão descritos detalhadamente na tabela 7 . 
Tabela 7: Características Clínicas dos Pacientes com ICV.

\begin{tabular}{|c|c|}
\hline & $I C V$ \\
\hline Manifestações Clínicas & $(n=35)$ \\
\hline \multicolumn{2}{|l|}{ Infecções Recorrentes (\%) } \\
\hline Sinusites & $19(90,5 \%)$ \\
\hline Pneumonias & $18(85,7 \%)$ \\
\hline Diarreia Crônica & $2(9,5 \%)$ \\
\hline Amigdalites & $1(5 \%)$ \\
\hline Otites & $2(9,5 \%)$ \\
\hline Infecções das Vias Aéreas & $1(5 \%)$ \\
\hline Meningites & $1(5 \%)$ \\
\hline Sepse & $1(5 \%)$ \\
\hline \multicolumn{2}{|c|}{ Doenças Pulmonares Crônicas (\%) } \\
\hline Bronquiectasias & $14(54 \%)$ \\
\hline \multicolumn{2}{|l|}{ Doenças Autoimunes (\%) } \\
\hline Citopenias & $4(36,4 \%)$ \\
\hline Vitiligo & $3(27,3 \%)$ \\
\hline Padrão Celíaco & $3(27,3 \%)$ \\
\hline Hipotireoidismo & $2(18,2 \%)$ \\
\hline Colite & $1(9,1 \%)$ \\
\hline Gastrite Atrófica & $1(9,1 \%)$ \\
\hline Diabetes Tipo I & $1(9,1 \%)$ \\
\hline \multicolumn{2}{|c|}{ Doenças Linfoproliferativas Benignas(\%) } \\
\hline Esplenomegalia & $10(38,5 \%)$ \\
\hline Linfadenopatia & $9(34,6 \%)$ \\
\hline \multicolumn{2}{|l|}{ Atopia $(\%)$} \\
\hline Rinite & $8(80 \%)$ \\
\hline Asma & $5(50 \%)$ \\
\hline Conjuntivite & $1(10 \%)$ \\
\hline \multicolumn{2}{|l|}{ Malignidade (\%) } \\
\hline Carcinoma Gástrico & $2(4 \%)$ \\
\hline Granulomatose (\%) & $0(0 \%)$ \\
\hline
\end{tabular}

Método diagnóstico: Bronquiectasias: Tomografia de Tórax; Linfadenopatia/ Esplenomegalia: exame clínico e ultrassom; Granulomatose: biópsia de lesão sugestiva; Autoimunidade: diagnóstico específico para cada manifestação segundo as sociedades específicas; Padrão Celíaco: diarréia crônica e biópsia de intestino compatível com doença celíaca, porém ausência de anticorpos anti-endomísio. Malignidade: diagnóstico específico para cada manifestação segundo as sociedades específicas; Atopia: história, exame físico sugestivos além de prova da função pulmonar para asma.

Como esperado, a manifestação clínica mais prevalente entre os 35 pacientes que participaram deste estudo, foram as infecções, sendo as sinusites (90,5\%) e as pneumonias $(85,7 \%)$ as manifestações mais relatadas. Estes pacientes também apresentaram alta prevalência de bronquiectasias (54\%).

Doenças autoimunes foram observadas em $42,3 \%$ dos pacientes, sendo as citopenias autoimunes $(36,4 \%)$ as manifestações mais observadas. 
Também foi observada uma alta prevalência de doenças linfoproliferativas benignas, sendo que $38,5 \%$ dos pacientes desenvolveram esplenomegalia e $34,6 \%$ apresentaram linfadenopatia.

Em relação aos sinais sugestivos de atopia, rinite (80\%) seguida de asma (50\%) foram as manifestações mais relatadas.

Por fim, dentre os 35 pacientes que participaram do estudo, foi observado que 2 (4\%) apresentavam doenças malignas já tratadas e nenhum paciente apresentou doença granulomatosa .

A avaliação clínica foi feita através da aplicação de um score de sintomas que pontuou de 0 a 5 os seguintes parâmetros: sinusites, infecções das vias aéreas superiores, otites, pneumonias, $\mathrm{ATB}^{5}$, amigdalites, internações e bronquiectasias. Os resultados da aplicação do score de sintomas para os 3 períodos avaliados se encontram na figura 9, que corresponde a mediana da soma das pontuações dos 8 parâmetros avaliados.

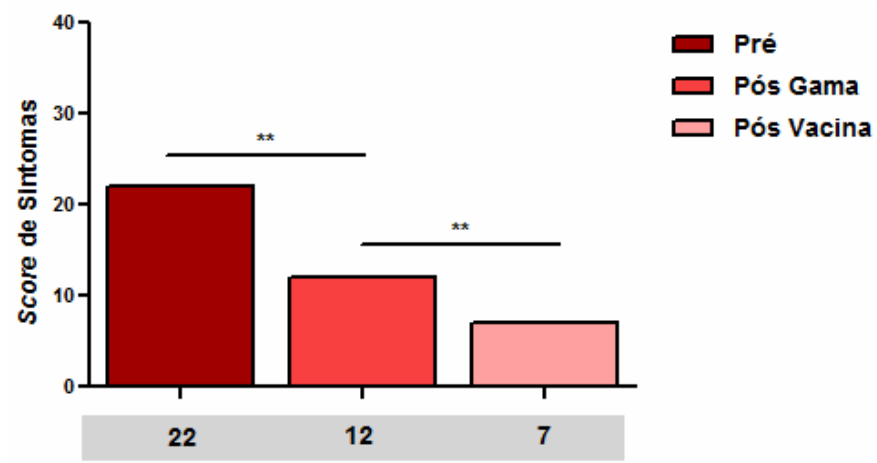

Figura 9: Avaliação Clínica. Os resultados representam a mediana da soma das pontuações dos 8 parâmetros a qual foi obtida através de um score de sintomas para avaliação do número e gravidade de infecções. A aplicação do score de sintomas foi realizada nos tempos: Vinho - antes do início do tratamento com IVIg; Salmão - após tratamento com IVIg mas antes da vacinação; Rosa - pós vacinação contra Influenza, H1N1 e S. pneumoniae. Valores estatisticamente significantes foram representados por (*) para $\mathrm{P}<0,05$ e $(* *)$ para $\mathrm{P}<0,001$.

\footnotetext{
${ }^{5}$ ATB: Antibioticoterapia.
} 
Antes do início do tratamento padrão, isto é, a reposição de imunoglobulinas, a mediana na pontuação total do score era de 22 pontos, porém após o início da reposição de IVIg, a pontuação do score apresentou média de 12 pontos, representando uma redução de 54,5\%. Esta redução foi estatisticamente significativa $(\mathrm{P}<0,001)$.

A comparação entre as pontuações dos períodos pós gama, o qual antecedia a vacinação e pós vacinação revelou uma diminuição mediana de 12 para 7 pontos, representando uma queda de $58,3 \%$ na pontuação total do score de sintomas, sendo esta estatisticamente significativa $(\mathrm{P}<0,001)$.

Considerando que nem todos os pacientes tomaram as três vacinas, também realizamos a comparação das pontuações do score de sintomas entre os grupos de pacientes que receberam apenas a vacina contra Influenza-H1N1 em relação aos que receberam as vacinas contra Influenza-H1N1 e Influenza-H2N3 e os pacientes que além destas vacinas, também receberam a vacina contra $S$. pneumoniae, a fim de verificar se os pacientes que receberam mais de uma vacina poderiam ter apresentado uma melhora clínica significativa em relação aos que tomaram apenas uma.

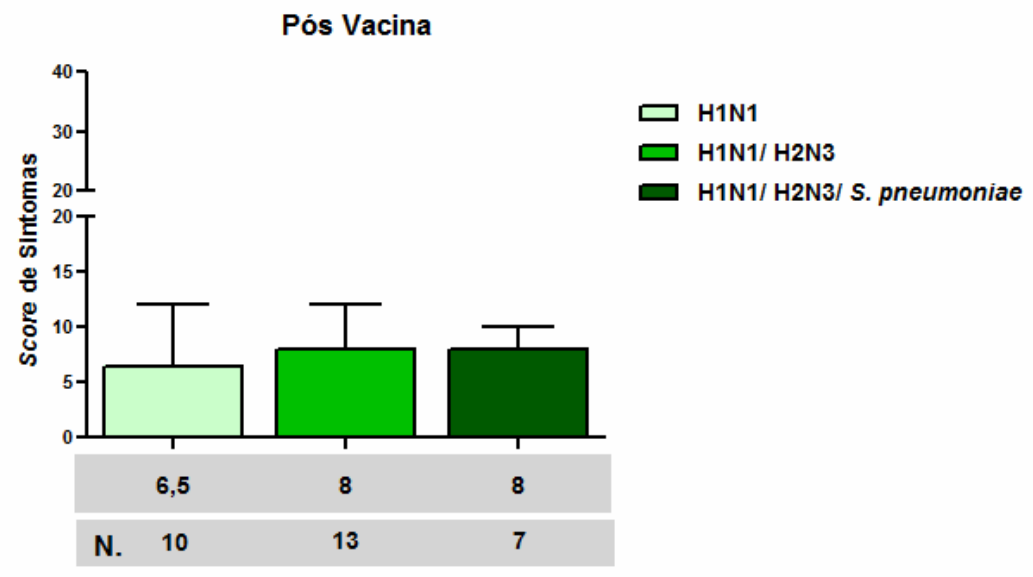

Figura 10: Avaliação Clínica Pós Vacinação - Comparação entre o Número de Vacinas. Os resultados representam a mediana obtida através do total da pontuação de um score de sintomas para os pacientes que receberam as vacinas anti- Influenza-H1N1, Influenza-H2N3 e S. pneumoniae. Comparação em relação ao número de vacinas. As linhas abaixo do gráfico correspondem às medianas o e número de pacientes de cada grupo. Valores estatisticamente significantes foram representados por $(*)$ para $\mathrm{P}<0,05$ e $(* *)$ para $\mathrm{P}<0,01$.

Como pode ser observado na figura 10, a comparação entre os pacientes que tomaram uma, duas ou as três vacinas não revelou haver diferença significativa entre 
eles $(\mathrm{p}=0,827)$, indicando que o paciente que recebeu apenas 1 vacina apresentou score de sintomas semelhante aos que receberam duas ou as três vacinas.

\subsection{Dosagem de Imunoglobulinas Séricas}

A dosagem de IgG sérica nos permitiu realizar a comparação entre os valores obtidos antes do início de reposição de imunoglobulinas com o período atual. A figura 11 descreve as médias obtidas para as concentrações séricas de $\operatorname{IgG}$ dos pacientes, respectivamente antes do início do tratamento e atualmente.

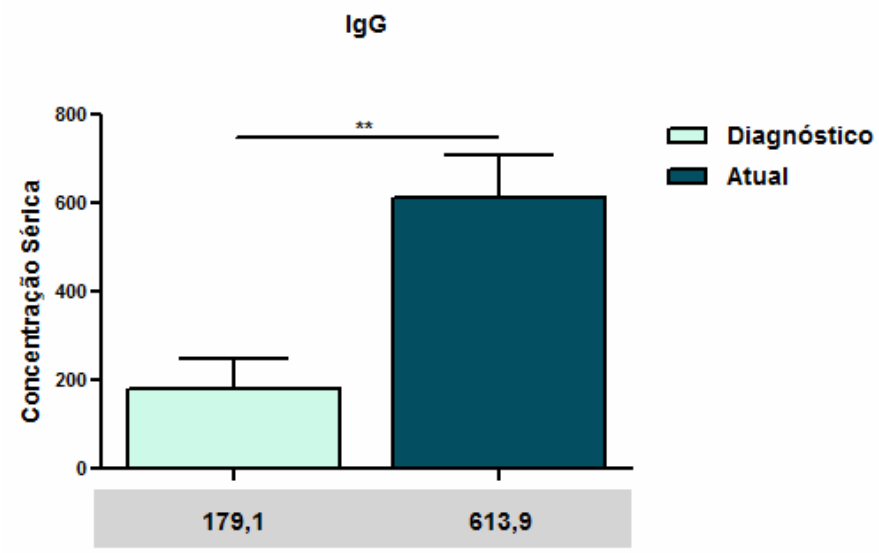

Figura 11: Concentração Sérica de IgG. A concentração sérica de IgG foi dosada antes do início do tratamento com reposição de imunoglobulinas e comparada com o período atual. As colunas mostram as médias das dosagens obtidas nos dois períodos. Valores estatisticamente significantes foram representados por $(*)$ para $\mathrm{P}<0,05$ e $(* *)$ para $\mathrm{P}<0,001$.

Como pode ser observado, a média da concentração sérica de IgG foi de 179,1 $\mathrm{mg} / \mathrm{dL}$ antes do início do tratamento e à época deste estudo foi de $613,9 \mathrm{mg} / \mathrm{dL}$, sendo este aumento estatisticamente significativo.

\subsection{Determinação de Anticorpos Específicos para Influenza}

A determinação de anticorpos específicos para Influenza foi feita com as amostras de soro de 13 pacientes e 16 controles, comparando-se os períodos pré vacinação e 1, 3 e 6 
meses após a vacinação. A figura 12 descreve os resultados para os controles em relação a todos os tempos avaliados.
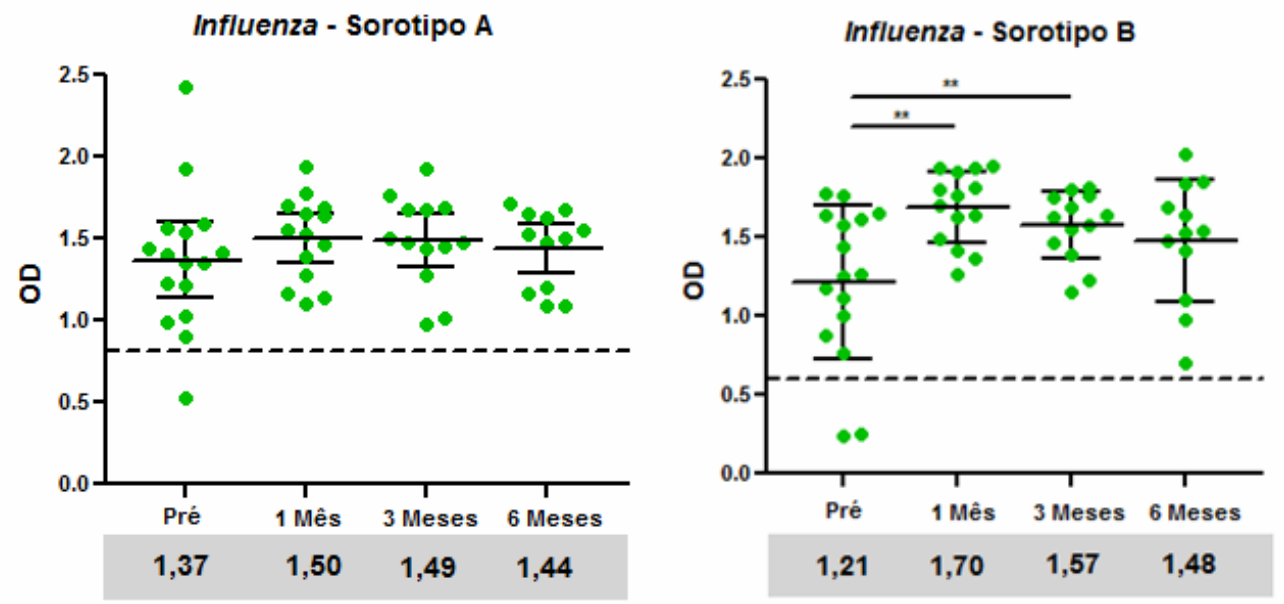

Figura 12: Determinação de Anticorpos Específicos para Influenza - Controles. Avaliação da densidade óptica (OD) nos períodos pré e pós vacinação contra Influenza dosados por meio da técnica de ELISA. Para o sorotipo A foram considerados os títulos positivos a partir de 0,82 e para o sorotipo B a partir de 0,60, representados no gráfico pela linha horizontal tracejada. Os resultados representam à média para cada período avaliado, a qual foi analisada por meio da média das duplicatas para cada uma das amostras testadas. Valores estatisticamente significantes foram representados por $(*)$ para $\mathrm{P}<0,05$ e $(* *)$ para $\mathrm{P}<0,001$.

Como pode ser observado, já no período pré vacinação, os controles apresentaram títulos de anticorpos específicos para os sorotipos A e B de Influenza, porém após a vacinação houve um aumento na produção de anticorpos específicos para ambos os sorotipos. A comparação em relação aos tempos avaliados para o sorotipo A indicou não haver uma diferença significativa entre eles, tanto na comparação do período pré vacina com pós 1 mês ( $\mathrm{p}=0,090)$, pós 3 meses $(\mathrm{p}=0,190)$ e pós 6 meses $(\mathrm{p}=0,622)$, assim como entre os períodos pós 1 e 3 meses $(\mathrm{p}=0,888)$ e pós 3 e 6 meses $(\mathrm{p}=0,289)$. Entretanto, a análise para o sorotipo B revelou ser significativa nos períodos pós 1 mês e pós 3 meses quando comparados ao período pré vacinação.

Os resultados da determinação de anticorpos específicos para Influenza para o grupo dos pacientes se encontram na figura 13. 

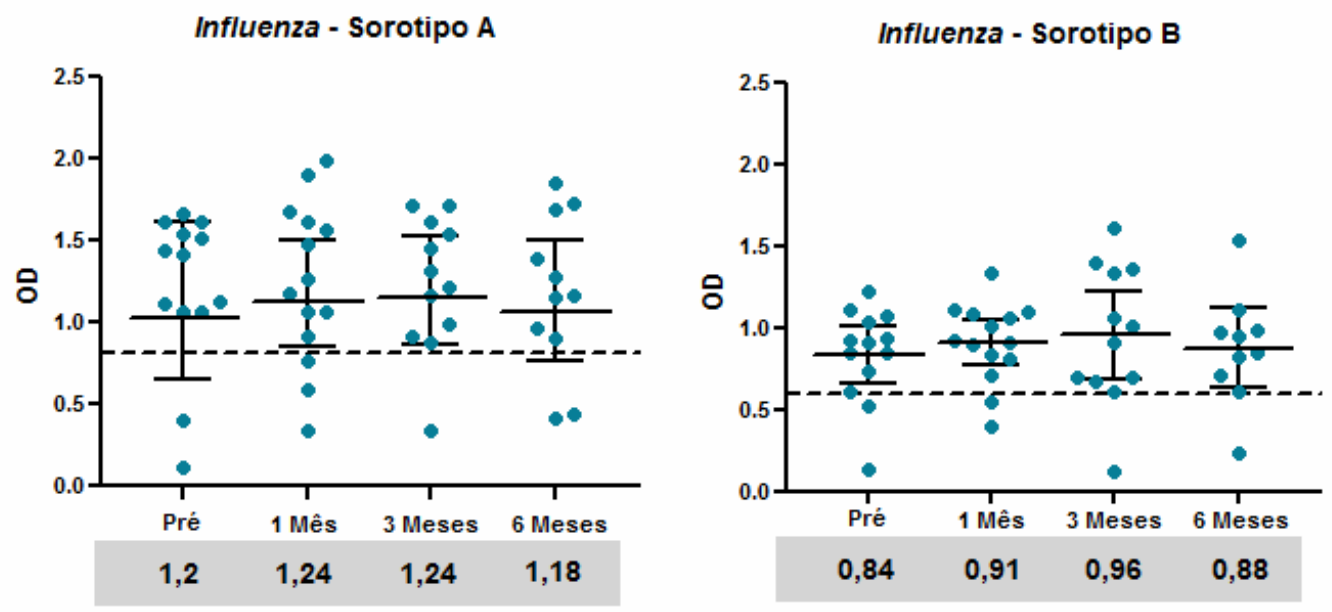

Figura 13: Determinação de Anticorpos Específicos para Influenza - Pacientes. Avaliação da densidade óptica (OD) nos períodos pré e pós vacinação contra Influenza dosados por meio da técnica de ELISA. Para o sorotipo A, foram considerados os títulos positivos a partir de 0,82 e para o sorotipo B a partir de 0,60 , representados no gráfico pela linha horizontal tracejada. Os resultados representam à média para cada período avaliado, a qual foi analisada por meio da média das duplicatas para cada uma das amostras testadas. Valores estatisticamente significantes foram representados por (*) para $\mathrm{P}<0,05$ e $(* *)$ para $\mathrm{P}<0,001$.

Assim como os controles, a maioria dos pacientes já apresentava títulos positivos de anticorpos específicos para os sorotipos A e B de Influenza. Em relação ao sorotipo A não houve uma diferença significativa quanto a comparação entre o período pré vacinação com pós 1 mês ( $\mathrm{p}=0,944)$, pós 3 meses $(\mathrm{p}=0,733)$ e pós 6 meses $(\mathrm{p}=0,700)$, assim como entre os períodos pós 1 e 3 meses $(p=0,569)$ e entre pós 3 e 6 meses $(\mathrm{p}=0,898)$.

Após a vacinação, diferentemente do observado para o grupo controle, não houve um aumento na produção de anticorpos específicos em relação ao sorotipo B, não sendo significativa a análise dos tempos pré vacinação com os períodos pós 1 mês $(\mathrm{p}=0,700)$, pós 3 meses ( $\mathrm{p}=0,301)$ e pós 6 meses ( $\mathrm{p}=0,845)$, assim como entre os períodos pós 1 e 3 meses $(\mathrm{p}=0,519)$ e 3 e 6 meses $(\mathrm{p}=0,492)$.

A comparação entre pacientes e controles para ambos os sorotipos também foi realizada e os resultados se encontram na figura 14. 

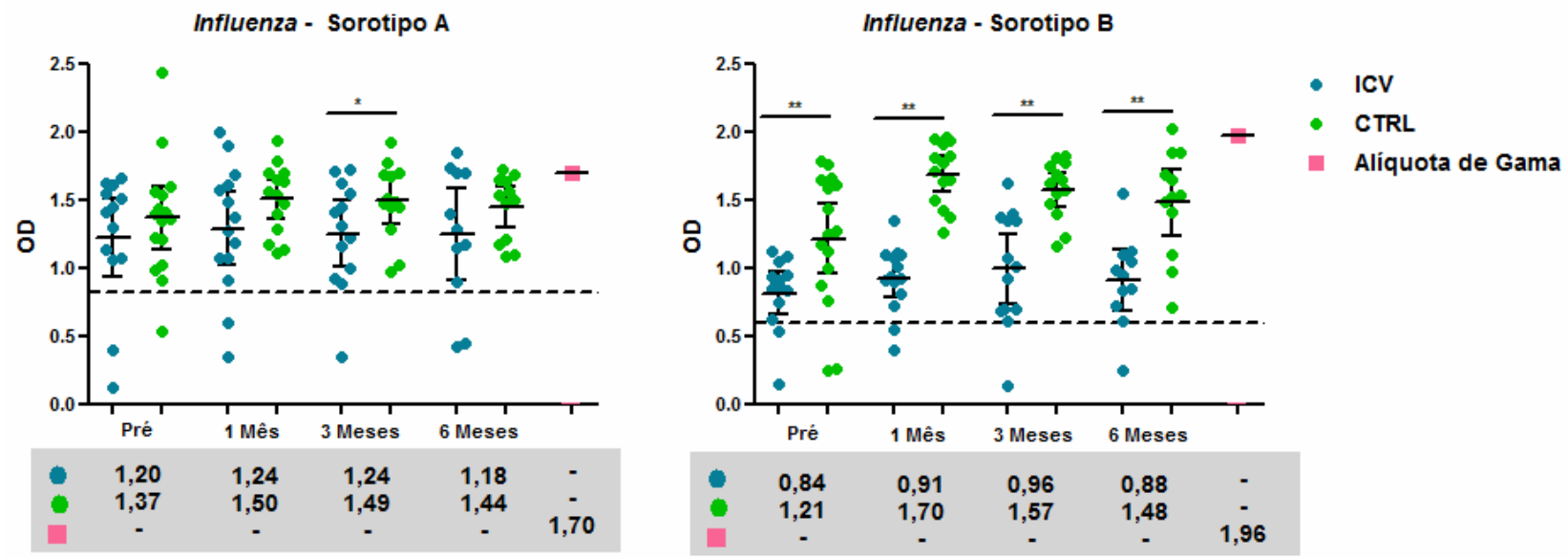

Figura 14: Determinação de Anticorpos Específicos para Influenza - Comparação entre Pacientes e Controles. Avaliação da densidade óptica (OD) nos períodos pré e pós vacinação contra Influenza dosados por meio da técnica de ELISA. Para o sorotipo A, foram considerados os títulos positivos a partir de 0,82 e para o sorotipo B a partir de 0,60 , representados no gráfico pela linha horizontal tracejada. Os resultados representam à média para cada período avaliado, a qual foi analisada por meio da média das duplicatas para cada uma das amostras testadas. Valores estatisticamente significantes foram representados por $(*)$ para $\mathrm{P}<0,05$ e $(* *)$ para $\mathrm{P}<0,01$.

Em relação ao sorotipo $\mathrm{A}$, não houveram diferenças significativas quanto a comparação entre pacientes e controles nos períodos pré $(\mathrm{p}=0,454)$ e pós 1 mês ( $\mathrm{p}=0,193)$. A comparação no período pós 3 meses foi estatisticamente significativa, porém não foi mantida até o sexto mês $(\mathrm{p}=0,174)$. Entretanto, quando o sorotipo $B$ foi avaliado, observamos que os controles apresentaram um aumento de IgG específico significativo em todos os tempos avaliados quando comparados aos pacientes.

Também foi realizada a dosagem de anticorpos específicos de uma alíquota de imunoglobulina humana da mesma marca e lote que estava sendo utilizada durante a realização das coletas e como pode ser observado, a alíquota de imunoglobulina apresentou níveis de anticorpos específicos para os sorotipos A e B semelhantes aos observados no grupo dos controles.

Por fim, também foi feita a análise da soroproteção para ambos os sorotipos, a qual foi calculada por meio da média de indivíduos que apresentaram título positivo igual ou superior a 0,82 para o sorotipo A e para o sorotipo $\mathrm{B}$, igual ou superior a 0,60 . A figura 15 descreve a porcentagem de soroproteção para pacientes e controles em cada um dos períodos avaliados. 
Sorotipo A

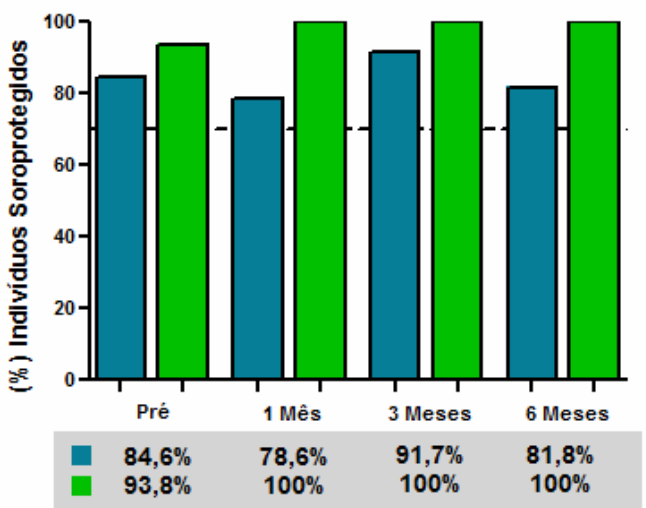

Sorotipo B

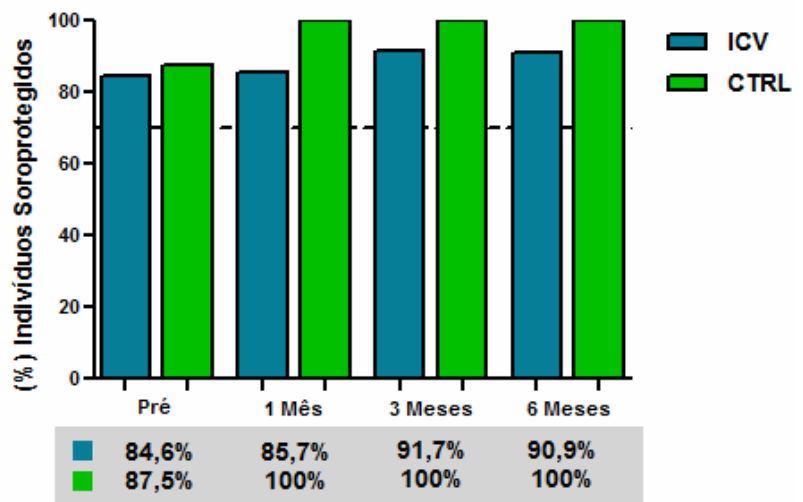

Figura 15: Determinação da Soroproteção para Influenza - Comparação entre Pacientes e Controles. A soroproteção foi considerada quando pelo menos $70 \%$ dos indivíduos apresentaram título positivo igual ou superior a 0,82 para o sorotipo A e 0,60 para o sorotipo B, representada pela linha horizontal tracejada e foi calculada como a porcentagem média de indivíduos para cada período. Valores estatisticamente significantes foram representados por $\left(^{*}\right)$ para $\mathrm{P}<0,05$.

A comparação entre a porcentagem de soroproteção de pacientes e controles revelou que ambos os grupos já apresentavam uma alta porcentagem de indivíduos soroprotegidos ao período pré vacinação, não sendo verificada uma diferença significativa tanto para o sorotipo $A(p=0,57)$ quanto para o sorotipo $B(p=1,0)$.

Após a vacinação, na avaliação do sorotipo A, podemos observar que $100 \%$ dos controles atingem o limiar de soroproteção, fato que não foi observado nos pacientes, entretanto, não foi observada uma diferença significativa entre os períodos pós 1 mês $(\mathrm{p}=0,22)$, pós 3 meses $(\mathrm{p}=0,48)$ e pós 6 meses $(\mathrm{p}=0,22)$. Assim como no o sorotipo A, a avaliação do sorotipo B revelou que após a vacinação todos os controles adquiriram soroproteção, porém a diferença entre os tempos pós 1 mês $(p=0,48), 3$ meses $(p=0,48)$ e pós 6 meses $(\mathrm{p}=0,48)$ não foi significativa.

Segundo a Agência Européia de Medicamentos (EMA, 1996), a taxa de soroproteção para vacinas contra Influenza deve estar acima de $70 \%$ para indivíduos com idade entre 18 a 60 anos, assim, verificamos que tanto nos pacientes quanto nos controles os títulos de anticorpos contra Influenza sazonal apresentaram-se em níveis protetores em todos os períodos avaliados. 


\subsection{Determinação de Anticorpos Específicos para H1N1}

Os anticorpos específicos para H1N1 foram quantificados através de um ensaio de hemaglutinação indireta nas amostras de soro de 21 pacientes e 16 controles.

Os resultados obtidos no grupo dos controles revelou que a maioria já apresentava títulos protetores no período pré vacinação, como pode ser observado na figura 16.

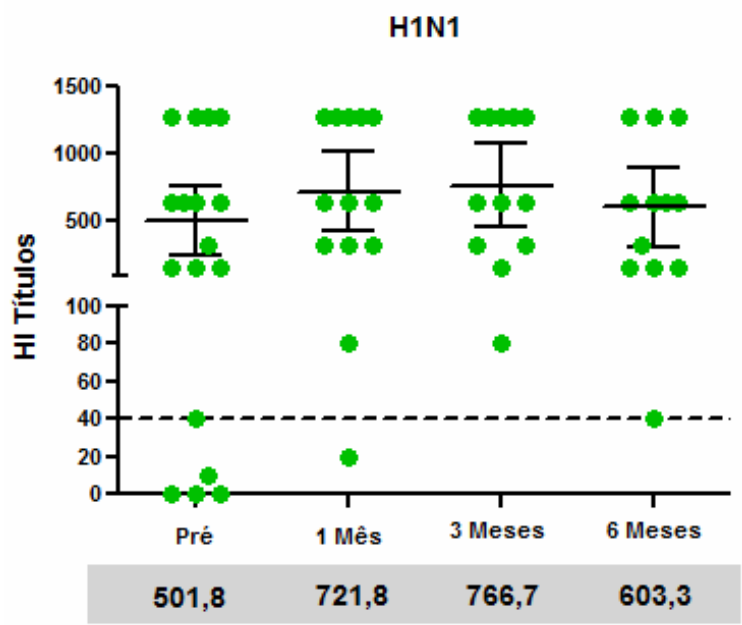

Figura 16: Determinação de Anticorpos Específicos para H1N1 - Controles. Títulos protetores de anticorpos contra H1N1 foram considerados a partir da diluição 1/40, representados pela linha tracejada no gráfico, dosados por meio da técnica de Hemaglutinação Indireta. Resultados referentes a média das duplicatas para cada uma das amostras testadas. Valores estatisticamente significantes foram representados por $(*)$ para $\mathrm{P}<0,05$ e $(* *)$ para $\mathrm{P}<0,01$.

Após a vacinação, houve um aumento na produção de anticorpos específicos, porém não foi possível verificar uma diferença significativa entre o período pré vacinação com pós 1 mês $(\mathrm{p}=0,313)$, pós 3 meses $(\mathrm{p}=0,342)$ e após 6 meses $(\mathrm{p}=0,833)$, assim como também entre os períodos pós 1 mês e 3 meses $(p=1,000)$ e pós 3 meses e 6 meses $(\mathrm{p}=0,232)$.

A figura 17 descreve os resultados obtidos para os pacientes e é possível observar que, ao contrário dos controles, a maioria dos pacientes não apresentava títulos protetores no período pré vacinação. 


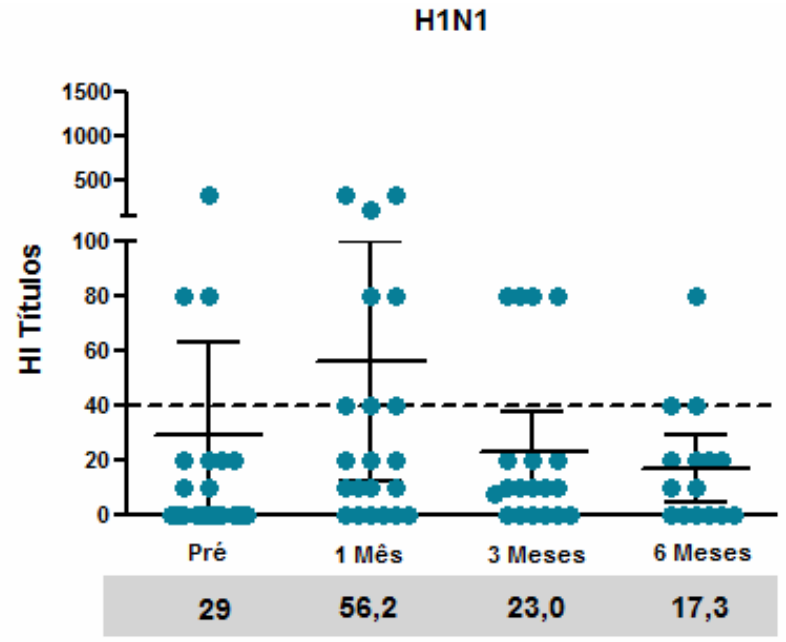

Figura 17: Determinação de Anticorpos Específicos para H1N1 - Pacientes. Títulos protetores de anticorpos contra H1N1 foram considerados a partir da diluição 1/40, representados pela linha tracejada no gráfico, dosados por meio da técnica de Hemaglutinação Indireta. Resultados referentes à média das duplicatas para cada uma das amostras testadas. Valores estatisticamente significantes foram representados por $(*)$ para $\mathrm{P}<0,05$ e $(* *)$ para $\mathrm{P}<0,01$.

Após a administração da vacina, alguns pacientes apresentaram um aumento no nível de anticorpos específicos já a partir do primeiro mês, porém estes decaíram com o passar dos meses. A análise estatística revelou não haver diferenças entre o período pré vacinação e pós 1 mês $(p=0,191), 3$ meses $(p=0,937)$ e 6 meses $(p=0,916)$. Também não foi verificada uma diferença significativa entre os períodos pós 1 mês e 3 meses $(\mathrm{p}=0,232)$ e pós 3 meses e 6 meses $(\mathrm{p}=0,385)$, por conta de a maioria dos pacientes não ter apresentado aumento na produção de anticorpos específicos para H1N1.

Também foi realizada a comparação entre pacientes e controles para cada um dos períodos estudados e os resultados se encontram na figura 18. 


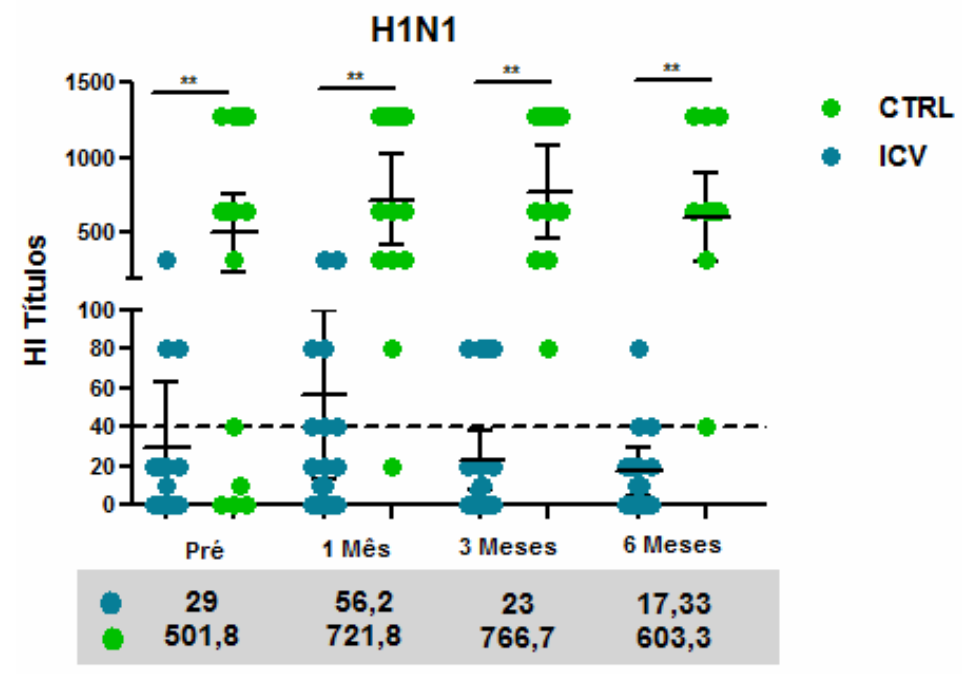

Figura 18: Determinação de Anticorpos Específicos para H1N1 - Comparação entre Pacientes e Controles. Títulos protetores de anticorpos contra H1N1 foram considerados a partir da diluição 1/40, representados no gráfico pela linha horizontal tracejada, dosados por meio da técnica de Hemaglutinação Indireta. Resultados referentes à média das duplicatas para cada uma das amostras testadas. Valores estatisticamente significantes foram representados por $(*)$ para $\mathrm{P}<0,05$ e $(* *)$ para $\mathrm{P}<0,01$.

Como pode ser observado, os controles apresentaram títulos de IgG específica para H1N1 estatisticamente maiores que o observado em pacientes em todos os tempos avaliados, inclusive já ao período pré vacinação.

A análise da soroproteção para H1N1 foi calculada por meio da média de indivíduos que apresentaram título positivo igual ou superior a diluição 1/40 e os resultados se encontram na figura 19. 


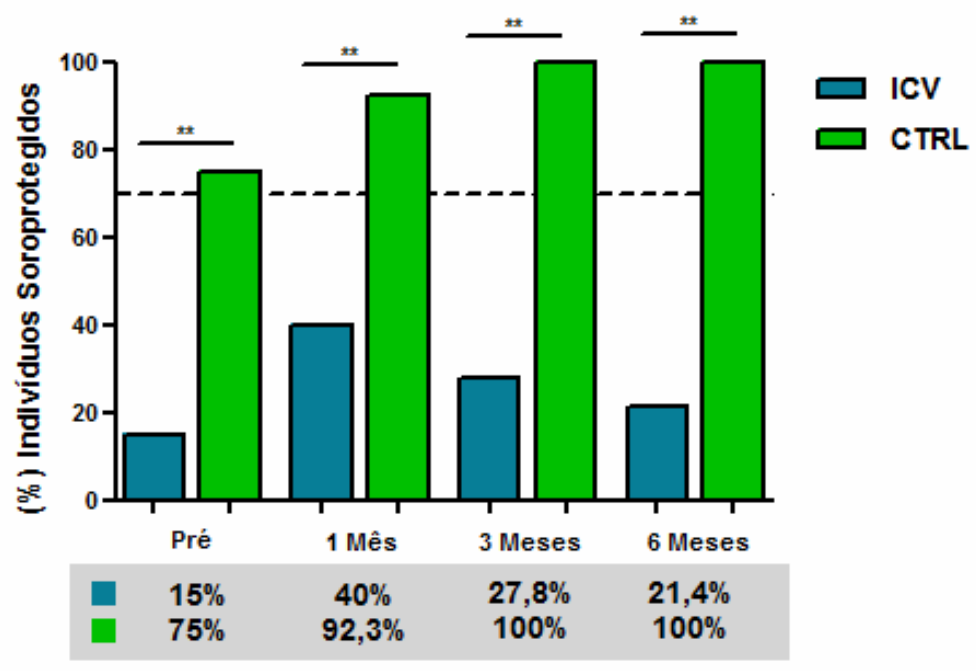

Figura 19: Determinação da Soroproteção para H1N1 - Comparação entre Pacientes e Controles. A soroproteção foi considerada quando pelo menos $70 \%$ dos indivíduos apresentaram título positivo igual ou superior a diluição de $1 / 40$, representada pela linha horizontal tracejada e foi calculada como a porcentagem média de indivíduos para cada período. Valores estatisticamente significantes foram representados por $(*)$ para $\mathrm{P}<0,05$ e $(* *)$ para $\mathrm{P}<0,01$.

A comparação entre pacientes e controles quanto a soroproteção para H1N1 revelou que já no período pré vacinação $75 \%$ dos indivíduos controles estavam soroprotegidos, ao contrário do grupo dos pacientes, onde apenas 15\% apresentavam títulos de anticorpos igual ou superior a diluição 1/40, sendo esta diferença estatisticamente significativa.

Após a vacinação, foi observado um aumento na taxa de soroproteção para ambos os grupos, porém ainda assim, os indivíduos controles apresentaram uma frequência de soroproteção estatisticamente superior aos pacientes em todos os períodos após a vacinação. Podemos também observar que no grupo dos controles a taxa de soroproteção aumentou gradativamente até o terceiro mês após a vacinação, onde $100 \%$ dos controles apresentaram títulos de anticorpos igual ou superior a diluição de 1/40 e que estes foram mantidos até o sexto mês após a vacinação, entretanto no grupo dos pacientes apesar de também ocorrer um aumento logo ao primeiro mês após a administração da vacina, a taxa de soroproteção começou a declinar já no terceiro mês.

Seguindo os critérios da Agência Européia de Medicamentos (EMA, 1996), nos indivíduos controles a vacina contra Influenza - H1N1 apresentou adequada taxa de soroproteção, a qual apresentou-se acima de $70 \%$ em todos os períodos avaliados, fato que não pode ser observado nos pacientes. 
Também foi realizada a análise da soroconversão para $\mathrm{H} 1 \mathrm{~N} 1$ em pacientes e controles, que foi determinada como a porcentagem média de indivíduos que apresentaram títulos de $\mathrm{HI} \geq 1 / 10$ no período pré vacinação e $\mathrm{HI} \geq 1 / 40$ após a vacinação ou títulos de $\mathrm{HI} \geq 1 / 10$ no período pré vacinação e um aumento de 4 vezes nos títulos de HI após a vacinação (EMA, 1996). A figura 20 descreve a análise da soroconversão para a vacina contra H1N1.

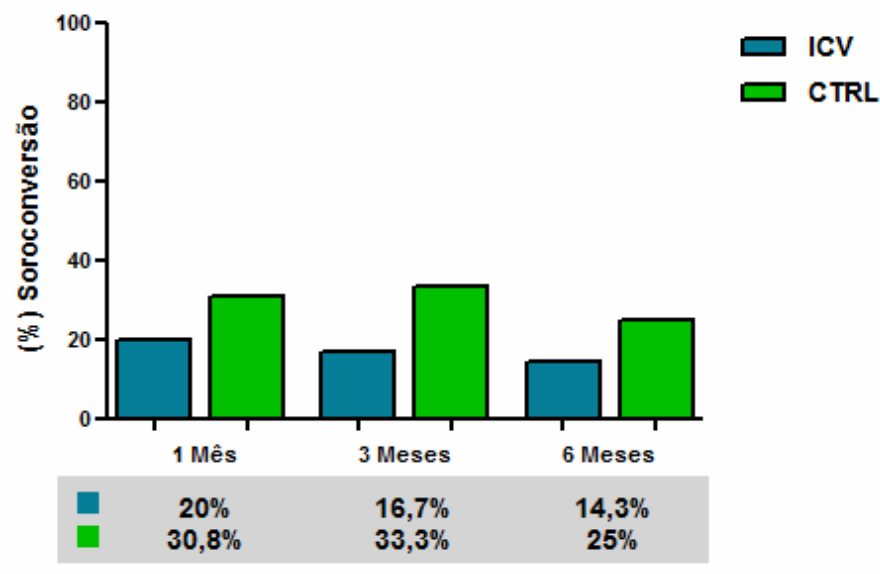

Figura 20: Determinação da Soroconversão para H1N1 - Comparação entre Pacientes e Controles. A soroconversão foi calculada como a porcentagem média de indivíduos que apresentaram título de HI $\geq$ $1 / 10$ no período pré vacinação e $\mathrm{HI} \geq 1 / 40$ após a vacinação ou títulos de $\mathrm{HI} \geq 1 / 10$ no período pré vacinação e um aumento de 4 vezes nos títulos de HI após a vacinação. Valores estatisticamente significantes foram representados por $(*)$ para $\mathrm{P}<0,05$.

Como pode ser observado, a taxa de soroconversão nos controles apresentou um gradativo aumento até o período pós 3 meses, decaindo logo em seguida, porém para os pacientes o aumento na taxa de soroconversão ocorreu logo ao primeiro mês após a administração da vacina, diminuindo precocemente. Comparando pacientes e controles, não foi possível verificar diferença estatisticamente significativa entre os períodos do pós 1 mês $(\mathrm{p}=0,680)$; pós 3 meses $(\mathrm{p}=0,390)$ e pós 6 meses $(0,640)$.

A taxa de soroconversão para vacinas contra Influenza devem estar acima de $40 \%$ para indivíduos com idade entre 18 a 60 anos, porém verificamos que tanto os pacientes quanto os controles apresentaram porcentagens de soroconversão menores que $40 \%$ ao longo dos meses avaliados. 


\subsection{Determinação de Anticorpos Específicos para Streptococcus pneumoniae}

A determinação de anticorpos específicos para $S$. pneumoniae foi realizada com as amostras de 4 pacientes e foram avaliados os sorotipos 1, 18C, 14, 9V, 5 e 6B, onde foram considerado os títulos de anticorpos protetores a partir da concentração de IgG sérica de $1,3 \mu \mathrm{g} / \mathrm{mL}$. A seguir na tabela 8 se encontram os resultados individuais de cada paciente para cada um dos sorotipos avaliados.

Tabela 8: Determinação de Anticorpos Específicos para S. pneumoniae - Resultados Individuais.

\begin{tabular}{|c|c|c|c|c|c|c|c|c|c|c|c|c|}
\hline \multirow[b]{2}{*}{ Identificação } & \multicolumn{4}{|c|}{$S P 1$} & \multicolumn{4}{|c|}{$S P 18 C$} & \multicolumn{4}{|c|}{$S P 14$} \\
\hline & Pré & 1 Mês & 3 Meses & 6 Meses & Pré & 1 Mês & 3 Meses & 6 Meses & Pré & 1 Mês & 3 Meses & 6 Meses \\
\hline CVD 16 & 0,35 & 0,28 & 0,62 & 0,37 & 0,5 & 0,4 & 0,74 & 0,37 & 0,63 & 0,28 & 0,92 & 0,69 \\
\hline CVD28 & 2,16 & 2,2 & 2,08 & 2,16 & 1,9 & 2,36 & 1,06 & 1,26 & 2,86 & 2,92 & 2,92 & 1,3 \\
\hline CVD 36 & 1,68 & 1,67 & 1,85 & 1,56 & 2,56 & 2,74 & 2,74 & 2,42 & 2,67 & 2,69 & 2,73 & 2,41 \\
\hline CVD47 & 0,47 & 0,36 & 0,43 & 0,38 & 0,54 & 0,57 & 0,6 & 0,38 & 0,51 & 0,66 & 0,7 & 0,55 \\
\hline \multirow[t]{2}{*}{ Identificação } & \multicolumn{4}{|c|}{$S P 9 V$} & \multicolumn{4}{|c|}{$S P 5$} & \multicolumn{4}{|c|}{$S P 6 B$} \\
\hline & Pré & 1 Mês & 3 Meses & 6 Meses & Pré & 1 Mês & 3 Meses & 6 Meses & Pré & $1 M e ̂ s$ & 3 Meses & 6 Meses \\
\hline CVD16 & 0,24 & 0,2 & 0,33 & 0,21 & 0,24 & 0,2 & 0,44 & 0,3 & 0,2 & 0,22 & 0,32 & 0,23 \\
\hline CVD28 & 2,75 & 2,61 & 2,86 & 1,59 & 2,77 & 2,84 & 3 & 2,57 & 2,9 & 2,53 & 2,36 & 1,47 \\
\hline CVD 36 & 2,07 & 1,95 & 2,03 & 2,05 & 2,87 & 2,76 & 2,81 & 2,81 & 2,91 & 1,28 & 1,27 & 1,42 \\
\hline CVID47 & 0,23 & 0,3 & 0,24 & 0,21 & 0,24 & 0,3 & 0,29 & 0,31 & 0,19 & 0,23 & 0,26 & 0,17 \\
\hline
\end{tabular}

Títulos protetores foram considerados a partir da concentração de $1,3 \mu \mathrm{g} / \mathrm{mL}$.

Dos pacientes avaliados podemos observar que 2 já apresentavam títulos de anticorpos específicos acima de $1,3 \mu \mathrm{g} / \mathrm{mL}$ para todos os sorotipos testados já no período pré vacinação. Após a administração da vacina, observamos que o paciente 28 manteve os altos títulos de IgG específico para os sorotipos 1, 14, 9V, 5 e 6B, já o paciente CVID36 conservou o nível de anticorpos acima de $1,3 \mu \mathrm{g} / \mathrm{mL}$ para os sorotipos $1,18 \mathrm{C}, 14,9 \mathrm{~V}$ e 5.

Em contrapartida, os pacientes CVID16 e CVID47 mantiveram os baixos títulos de anticorpos específicos do período pré vacinação para todos os sorotipos avaliados em todos os períodos após a vacinação.

A seguir na figura 21 se encontra a média para cada sorotipo obtida nos períodos pré e pós vacinação. 

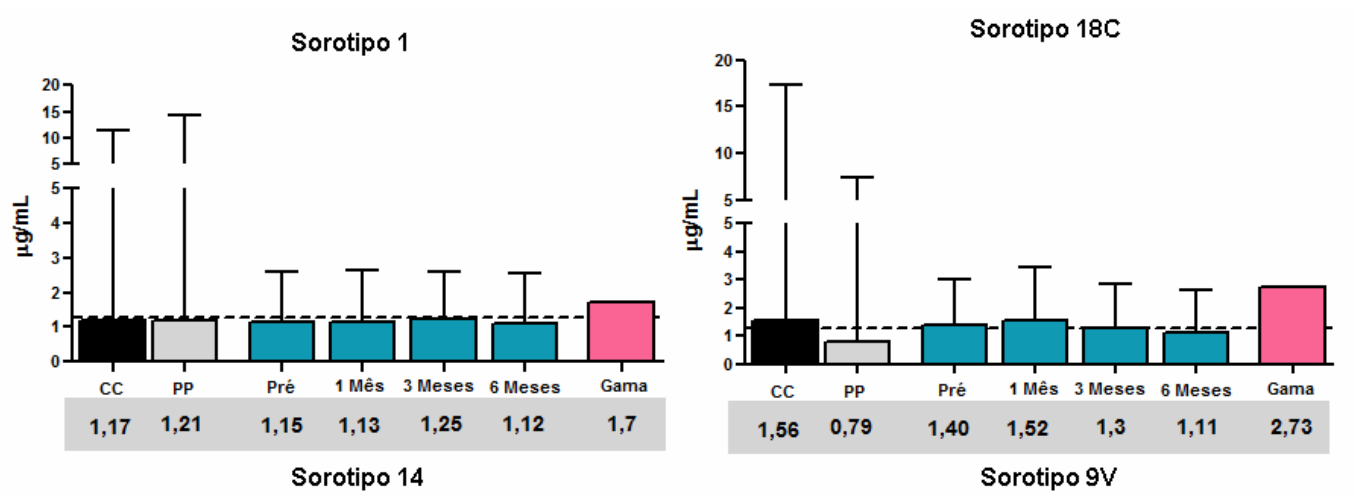

- Curva Controle

$\square$ Pool Pneumo

$\square$ Alíquota de Gama
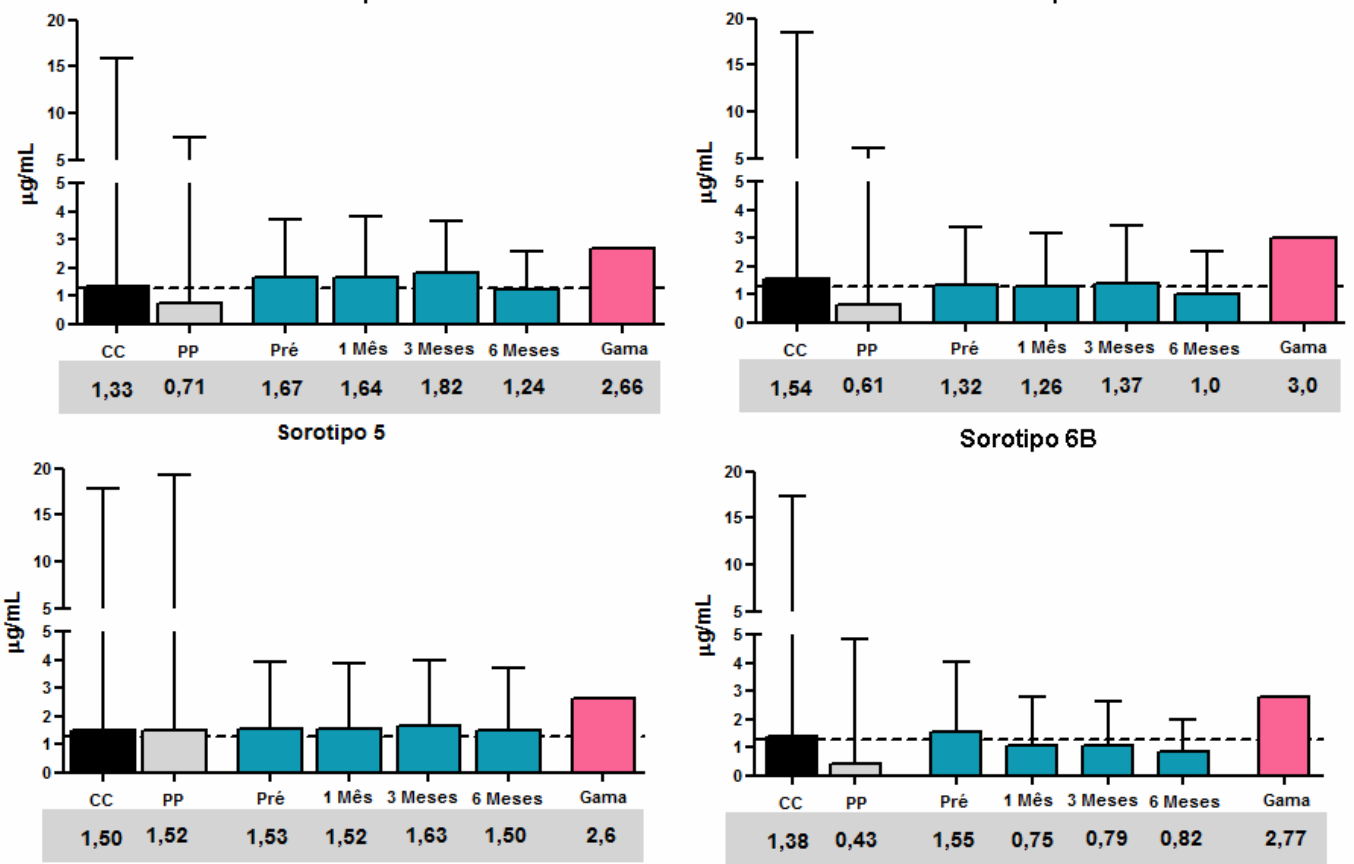

Figura 21: Determinação de Anticorpos Específicos para S. pneumoniae - Sorotipos. Títulos protetores de anticorpos contra $S$. pneumoniae foram considerados a partir da concentração sérica de $\operatorname{IgG}$ específico de $1,3 \mu \mathrm{g} / \mathrm{mL}$, representados no gráfico pela linha horizontal tracejada, dosados por meio de ELISA. Resultados referentes a média das duplicatas para cada uma das amostras testadas. Curva Controle: pool de soros de indivíduos não vacinados ; Pool Pneumo: pool de soros de indivíduos vacinados. Valores estatisticamente significantes foram representados por $(*)$ para $\mathrm{P}<0,05$; $(* *)$ para $\mathrm{P}<$ 0,01 .

\subsection{Subpopulações de Linfócitos B}

Foram estudadas quatro subpopulações de LB em amostras de $\mathrm{CMSP}^{6}$ de pacientes com ICV e controles estimulados com lisado viral e o peptídeo hemaglutinina de Influenza nos tempos pré e 1, 3 e 6 meses após a vacinação.

\footnotetext{
${ }^{6}$ CMSP: Células Mononucleares de Sangue Periférico.
} 
Partimos da subpopulação de linfócitos B naive, definida por expressar as moléculas $\mathrm{CD}_{19}{ }^{+} \mathrm{CD} 27^{-} \operatorname{IgD}{ }^{+} \operatorname{IgM} \mathrm{M}^{+}$. A figura 22 mostra os resultados da frequência de linfócito $\mathrm{B}$ naive em pacientes e controles nos tempos pré e pós vacinação.

ICV

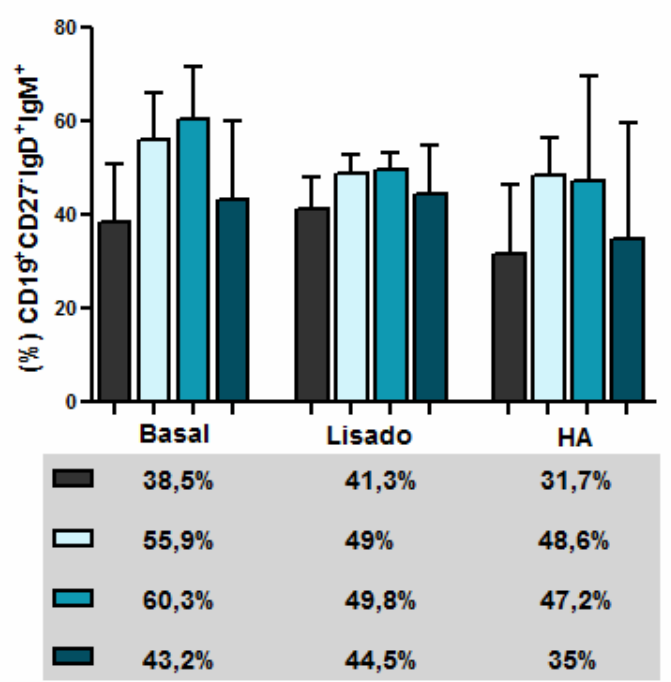

Controles

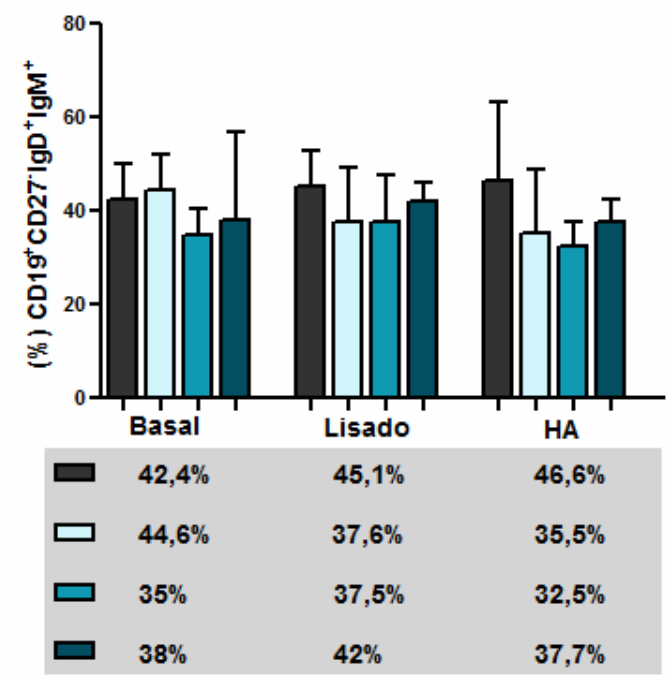

$\square$ Pré Vacina $\square$ Pós 1 Mês $\square$ Pós 3 Meses $\square$ Pós 6 Meses

Figura 22: Frequência da Subpopulação de Linfócitos B Naive Pré e Pós Vacinação Contra Influenza. Os resultados foram expressos como mediana da porcentagem da subpopulação de linfócitos B naive em indivíduos controles e pacientes com ICV nos tempos Pré Vacinação, Pós 1 Mês, Pós 3 Meses e Pós 6 Meses. Valores estatisticamente significantes foram representados por (*) para $\mathrm{P}<0,05$; (**) para $\mathrm{P}<0,01$. Lisado: lisado viral de Influenza na concentração de $30 \mathrm{ng} / \mathrm{mL}$; HA: peptídeo hemaglutinina de Influenza na concentração de $2,5 \mu \mathrm{g} / \mathrm{mL}$.

Em relação aos controles, não foi observada uma diferença significativa na frequência de LB naive entre os tempos avaliados, tanto na condição basal, quanto após a estimulação com lisado viral e o peptídeo hemaglutina de Influenza. Em contrapartida, ao analisarmos os pacientes, verificamos um ligeiro aumento na frequência de LB naive que foi mantido até o terceiro mês após a administração da vacina, porém, apesar da tendência também não houve diferença significativa entre os tempos estudados.

Os linfócitos $\mathrm{B}$ de zona marginal são identificados por expressarem $\mathrm{CD} 19^{+} \mathrm{CD} 27^{+} \operatorname{IgD}^{+} \operatorname{IgM}^{+}$e a figura 23 mostra os resultados obtidos para esta subpopulação tanto em pacientes quanto controles nos diferentes tempos estudados. 

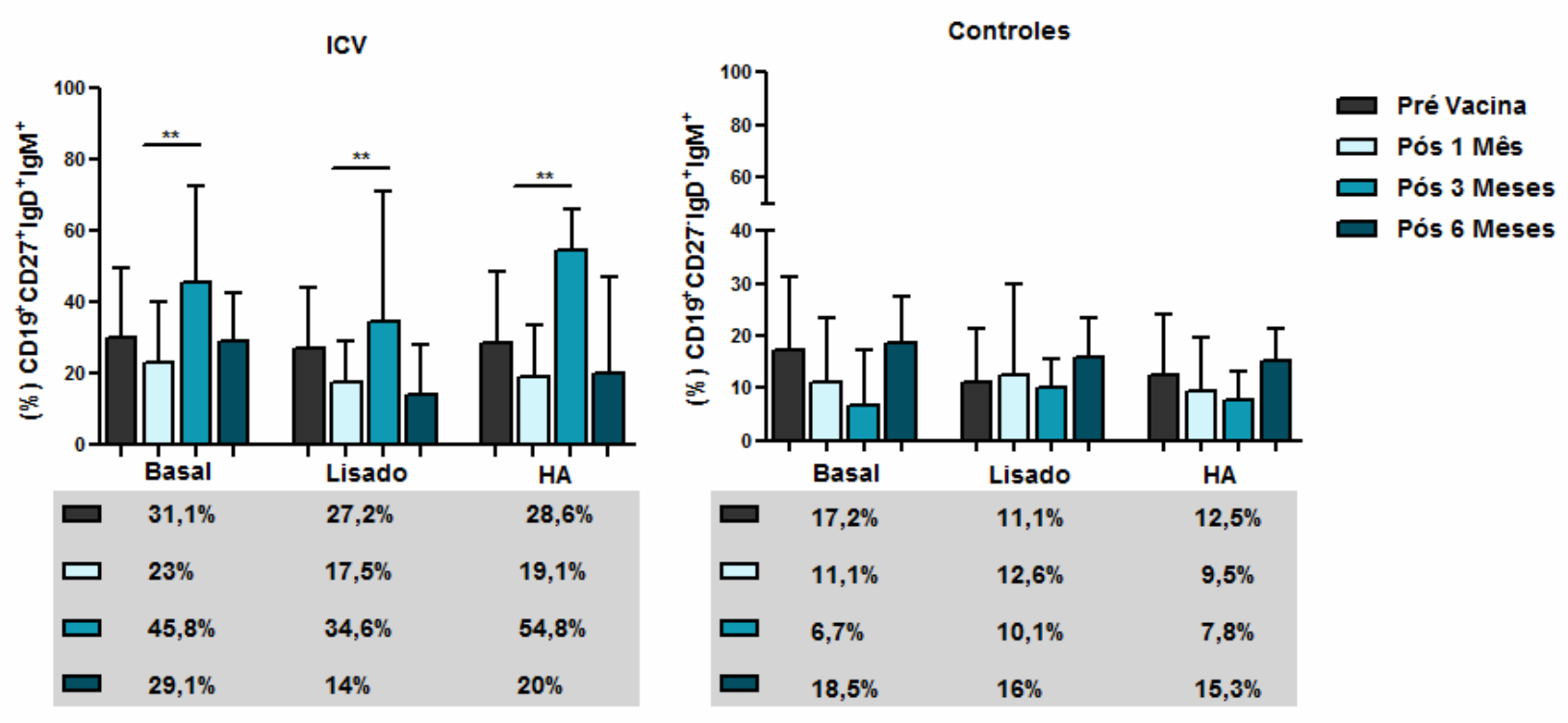

Figura 23: Frequência da Subpopulação de Linfócitos B de Zona Marginal Pré e Pós Vacinação Contra Influenza. Os resultados foram expressos como mediana da porcentagem da subpopulação de linfócitos B de zona marginal em indivíduos controles e pacientes com ICV nos tempos Pré Vacinação, Pós 1 Mês, Pós 3 Meses e Pós 6 Meses. Valores estatisticamente significantes foram representados por (*) para $\mathrm{P}<0,05$; (**) para $\mathrm{P}<0,01$. Lisado: lisado viral de Influenza na concentração de $30 \mathrm{ng} / \mathrm{mL}$; HA: peptídeo hemaglutinina de Influenza na concentração de $2,5 \mu \mathrm{g} / \mathrm{mL}$.

Observamos que os controles apresentaram uma diminuição na frequência de MZB após a vacinação, sendo que à estimulação com o peptídeo HA no período pós 1 mês, verificamos uma queda de $24 \%$ na frequência deste subtipo de LB e no período pós 3 meses esta diminuição foi de 37,5\% quando comparada ao nível pré vacinação, porém a análise estatística revelou não haver uma diferença significativa entre os tempos estudados.

Em relação aos pacientes, observamos que no primeiro mês após a vacinação, assim como nos controles, ocorreu uma diminuição na frequência de MZB, embora não significativa. Já após o terceiro mês, observamos um aumento expressivo deste subtipo de LB, sendo este observado na condição basal $(47,3 \%)$ e após a estimulação com lisado viral $(27,2 \%)$ e peptídeo HA $(91,6 \%)$ respectivamente, quando comparados à frequência do período pré vacinação. Este aumento, como pode ser observado foi estatisticamente significativo em todas as condições avaliadas.

A figura 24 mostra os resultados obtidos para a subpopulação de LB de memória com troca de isotipo, que é definido como $\mathrm{CD} 19^{+} \mathrm{CD} 27^{+} \operatorname{IgD}^{-} \operatorname{IgM}^{-}$. 
ICV

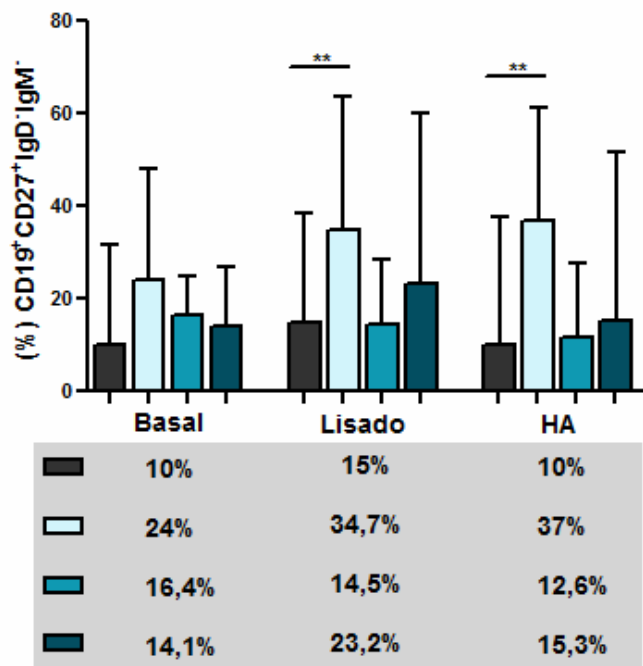

Controles

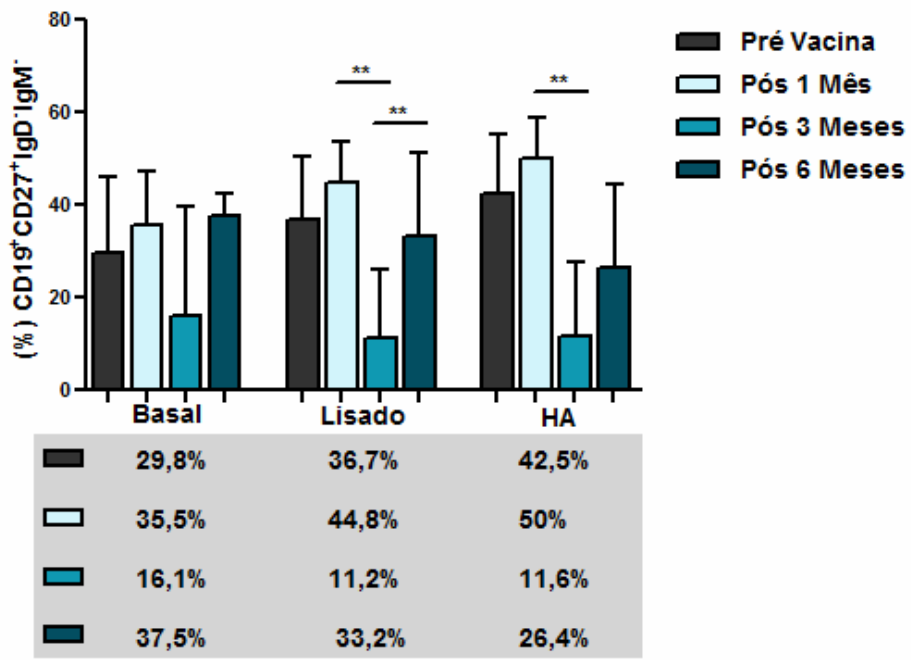

Figura 24: Frequência da Subpopulações de Linfócitos B de Memória com Troca de Isotipo Pré e Pós Vacinação Contra Influenza. Os resultados foram expressos como mediana da porcentagem da subpopulação de linfócitos B de memória com troca de isotipo em indivíduos controles e pacientes com ICV nos tempos: Pré Vacinação, Pós 1,3 e 6 Meses. Valores estatisticamente significantes foram representados por (*) para $\mathrm{P}<0,05$; (**) para $\mathrm{P}<0,01$. Lisado: lisado viral de Influenza na concentração de $30 \mathrm{ng} / \mathrm{mL}$; HA: peptídeo hemaglutinina de Influenza na concentração de 2,5 $\mu \mathrm{g} / \mathrm{mL}$.

Tanto controles quanto pacientes apresentaram um aumento de $\mathrm{SMB}^{7}$ após 1 mês de vacinação, porém apenas nos pacientes este aumento foi estatisticamente significativo, sendo que à estimulação com o lisado viral foi possível verificar um aumento de $131 \%$ na frequência de SMB comparado aos valores obtidos no período pré vacinação e em relação ao peptídeo HA, o aumento foi de $270 \%$.

No terceiro mês após a vacinação, foi observada uma queda na frequência deste subtipo de LB em ambos os grupos. Os controles apresentaram uma redução na frequência de SMB tanto com o lisado viral quanto com o peptídeo HA, representando uma diminuição de $69 \%$ e $72,7 \%$ respectivamente quando comparados ao nível pré vacinação. Entretanto, quando comparado ao período pós 1 mês, esta queda foi ainda maior, sendo estatisticamente significativa tanto para o lisado viral $(91,5 \%)$ quanto para o peptídeo HA (90,3\%). Quanto aos pacientes, também foi observada esta queda no terceiro mês após a vacinação, tanto para lisado viral (3\%) quanto para o peptídeo HA (25\%) quando comparado com a frequência de SMB do período pré vacina, assim como

\footnotetext{
${ }^{7}$ SMB: LB de Memória com Troca de Isotipo.
} 
também para o período pós 1 mês, onde foram observadas uma diminuição de 116,7\% após a cultura com lisado viral e $245 \%$ para o peptídeo HA respectivamente porém, diferentemente do observado para os controles, não verificamos uma diferença significativa para os pacientes.

Ao sexto mês observamos que a frequência de SMB volta a apresentar valores semelhantes ao observado no período pré vacinação tanto nos controles quanto nos pacientes, sendo o aumento da sua expressão estatisticamente significativo após a cultura com lisado viral para os controles quando comparado ao período pós 3 meses.

Por fim, foi realizada a análise da subpopulação de plasmoblastos (PBL), que foram definidos por serem $\mathrm{CD} 19^{+} \mathrm{CD} 38^{+} \mathrm{CD} 27^{+} \mathrm{IgM}^{-}$. Os resultados podem ser observados na figura 25.
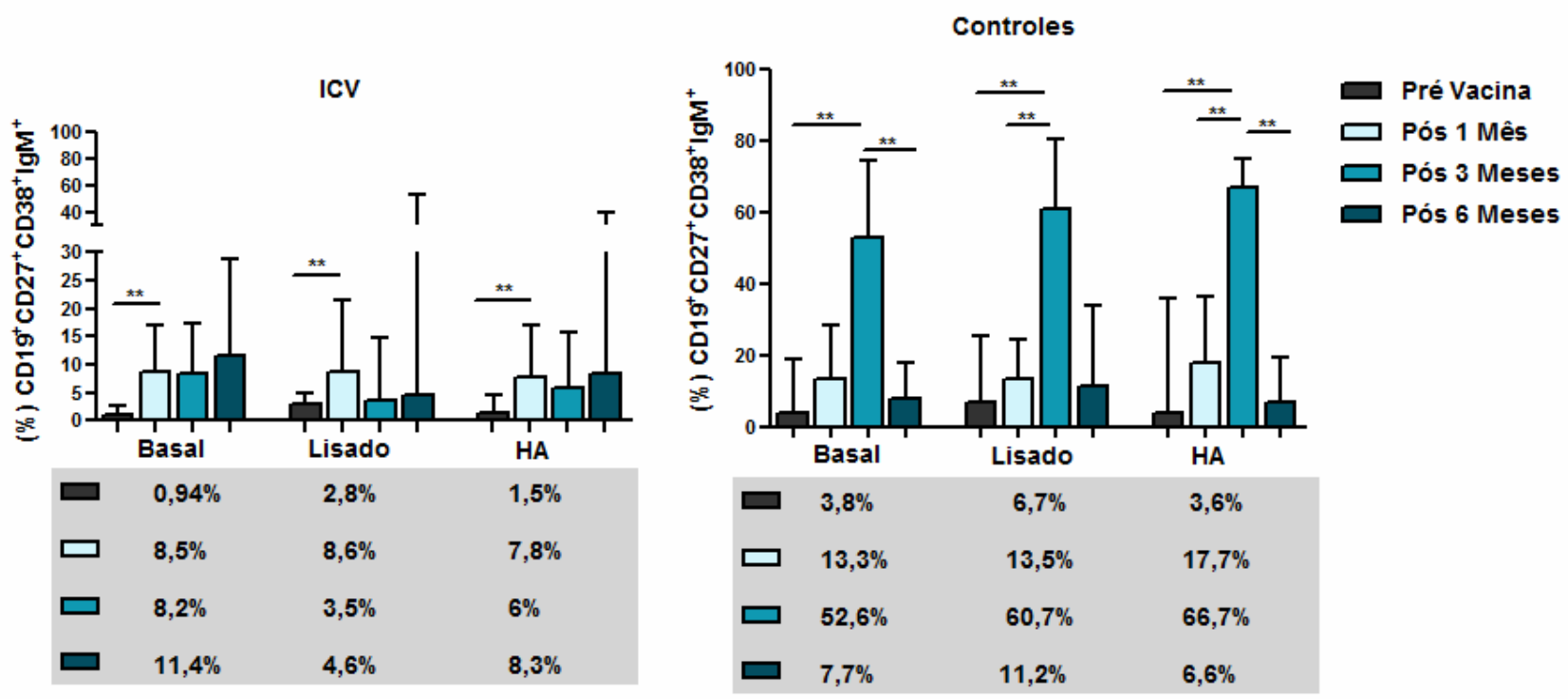

Figura 25: Frequência da Subpopulação Plasmoblastos Pré e Pós Vacinação Contra Influenza. Os resultados foram expressos como mediana da porcentagem de plasmoblastos para indivíduos controles e pacientes com ICV nos tempos: Pré Vacinação, Pós 1,3 e 6 Meses. Valores estatisticamente significantes foram representados por $(*)$ para $\mathrm{P}<0,05 ;(* *)$ para $\mathrm{P}<0,01$. Lisado: lisado viral de Influenza na concentração de 30 ng/mL; HA: peptídeo hemaglutinina de Influenza na concentração de 2,5 $\mu \mathrm{g} / \mathrm{mL}$.

Observamos um aumento gradativo na frequência de $\mathrm{PBL}^{8}$ no grupo dos controles após a vacinação, com pico 3 meses após a administração da vacina e decaindo

\footnotetext{
${ }^{8}$ PBL: Plasmoblasto.
} 
subsequentemente. Este aumento foi significativo tanto na condição basal como também após estímulo com lisado viral e HA quando comparado com os períodos pré vacinação e pós 1 mês. No período pós 6 meses, observamos uma queda na frequência deste subtipo em todas as condições avaliadas, porém sendo estatisticamente significativa na condição basal e na cultura com HA.

Em relação ao grupo dos pacientes, também foi observado um aumento na frequência de PBL após a vacinação, porém bem menor quando comparado aos controles. Este aumento é observado logo no primeiro mês após a administração da vacina e foi estatisticamente significativo para as condições basal, lisado viral e HA, ocorrendo um aumento na frequência de $804 \%, 207 \%$ e $420 \%$ respectivamente, quando comparados às freqüências do período pré vacinação. Após o terceiro mês da administração das vacinas, observamos uma queda gradativa na expressão deste subtipo tanto nas células cultivadas com lisado viral como com peptídeo HA, porém sem diferença estatística entre os períodos estudados.

A seguir as figuras 26 e 27 demonstram a cinética da frequência de cada uma das subpopulações de LB na condição basal e após cultura com lisado viral e HA em indivíduos controles e pacientes com ICV nos períodos pré e pós vacinação. 

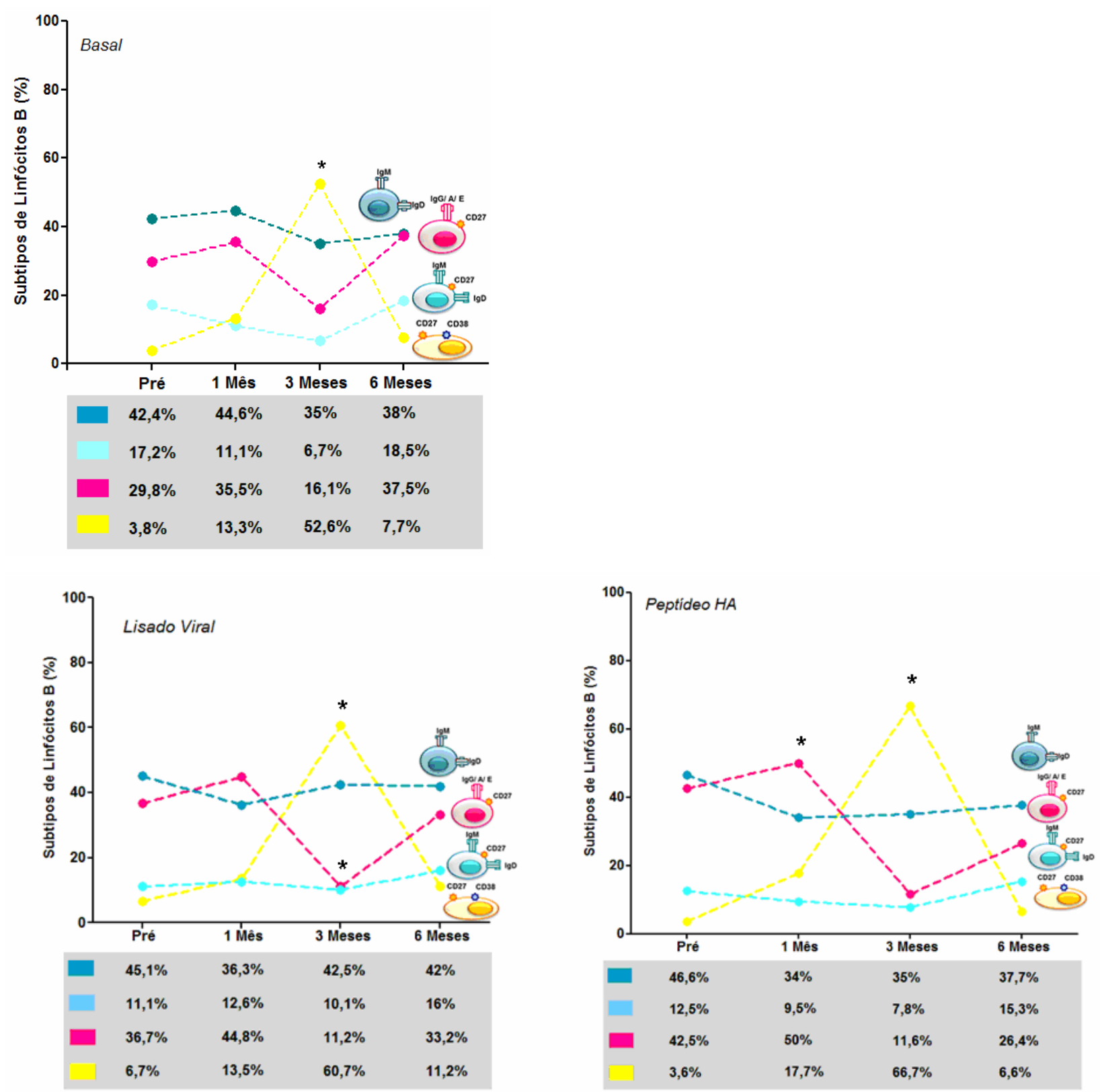

Linfócito B Naive Linfócito B de Zona Marginal

Linfócito B de Memória com Troca de Isotipo

Plasmoblasto

Figura 26: Cinética dos Subtipos de Linfócitos B Após Administração da Vacina de Influenza Controles. Os resultados foram expressos como mediana da porcentagem de cada uma das subpopulações de linfócitos B em indivíduos controles no tempos: Pré Vacinação, Pós 1,3 e 6 Meses, após a cultura sem estimulo (basal) ou com os estímulos Lisado Viral (lisado viral de Influenza na concentração de $30 \mathrm{ng} / \mathrm{mL}$ ) ou Peptídeo HA (peptídeo hemaglutinina de Influenza na concentração de 2,5 $\mu \mathrm{g} / \mathrm{mL})$. 

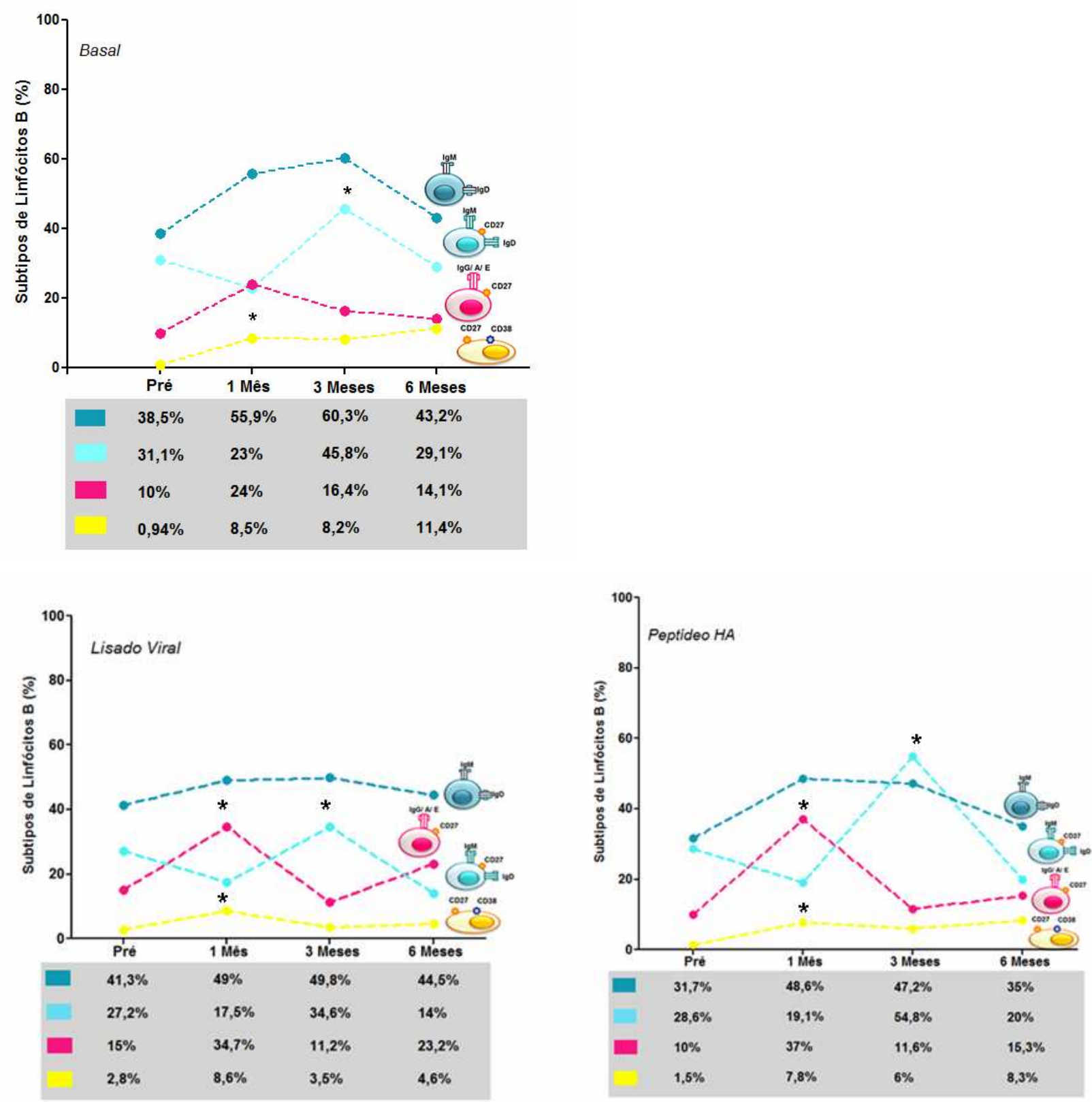

Figura 27: Cinética dos Subtipos de Linfócitos B Após Administração da Vacina de Influenza ICV. Os resultados foram expressos como mediana da porcentagem de cada uma das subpopulações de linfócitos B em pacientes com ICV no tempos: Pré Vacinação, Pós 1,3 e 6 Meses, após a cultura sem estimulo (basal) ou com os estímulos Lisado Viral (lisado viral de Influenza na concentração de 30 ng/mL) ou Peptídeo HA (peptídeo hemaglutinina de Influenza na concentração de 2,5 $\mu \mathrm{g} / \mathrm{mL}$ ). 
Também foi realizada a comparação entre pacientes e controles para cada um dos subtipos de linfócitos B em cada um dos períodos estudados. A seguir na figura 28 se encontram os resultados da comparação da frequência de linfócitos B naive.
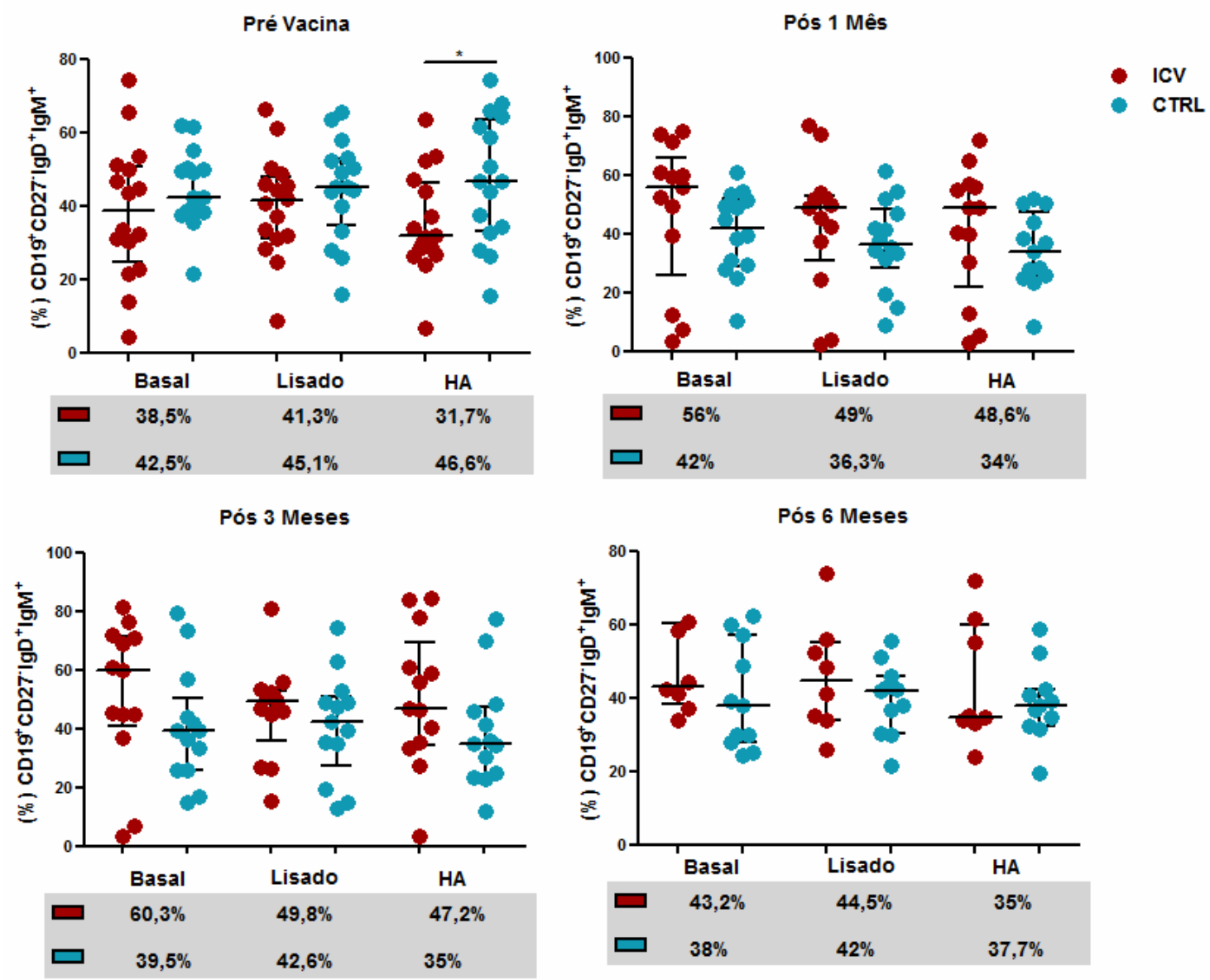

Figura 28: Frequência da Subpopulação de Linfócitos B Naive Pré e Pós Vacinação Contra Influenza - Comparação entre Pacientes e Controles. Os resultados foram expressos como mediana da porcentagem da frequência para a subpopulação de LB naive de indivíduos controles e pacientes com ICV, representados em azul e vermelho respectivamente. Comparação entre os tempos pré e pós 1, 3 e 6 meses, após a cultura com os estímulos Lisado Viral (lisado viral de Influenza na concentração de 30 $\mathrm{ng} / \mathrm{mL}$ ) ou Peptídeo HA (peptídeo hemaglutinina de Influenza na concentração de 2,5 $\mu \mathrm{g} / \mathrm{mL}$ ). Valores estatisticamente significantes foram representados por $(*)$ para $\mathrm{P}<0,05 ;(* *)$ para $\mathrm{P}<0,01$.

A comparação da subpopulação de LB naive entre pacientes e controles revelou que os controles apresentaram um aumento estatisticamente significativo da frequência deste subtipo no período pré vacinação após estímulo com o peptídeo HA de Influenza. Entretanto nos meses que se seguiram após a administração da vacina é possível verificar que os pacientes apresentaram uma maior expressão desta subpopulação de LB que os indivíduos controles, porém sem diferenças entre os grupos. 
A seguir, a figura 29 mostra a cinética da frequência de LB naive após a cultura com lisado viral e HA em indivíduos controles e pacientes com ICV para os períodos pré e pós vacinação.
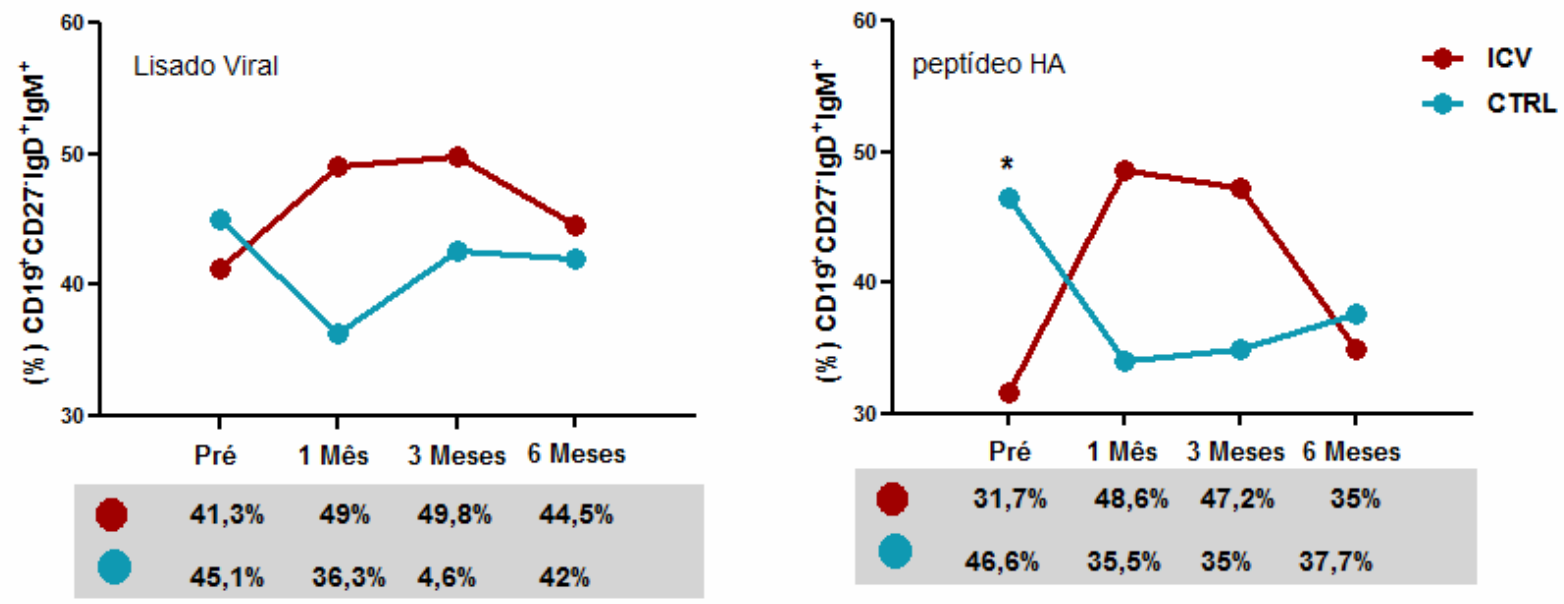

Figura 29: Cinética de LB Naive Após Administração da Vacina de Influenza e Estimulação com Lisado Viral ou Peptídeo HA - Comparação entre ICV e Controles. Os resultados foram expressos como mediana da porcentagem de LB naive para pacientes com ICV e controles, no tempos: Pré Vacinação, Pós 1, 3 e 6 Meses, após a cultura com os estímulos Lisado Viral (lisado viral de Influenza na concentração de $30 \mathrm{ng} / \mathrm{mL}$ ) ou Peptídeo HA (peptídeo hemaglutinina de Influenza na concentração de 2,5 $\mu \mathrm{g} / \mathrm{mL})$. Valores estatisticamente significantes foram representados por $(*)$ para $\mathrm{P}<0,05$; $(* *)$ para $\mathrm{P}<$ 0,01 .

A seguir na figura 30 se encontram os resultados da comparação entre pacientes e controles para a subpopulação de linfócito B de Zona Marginal. 

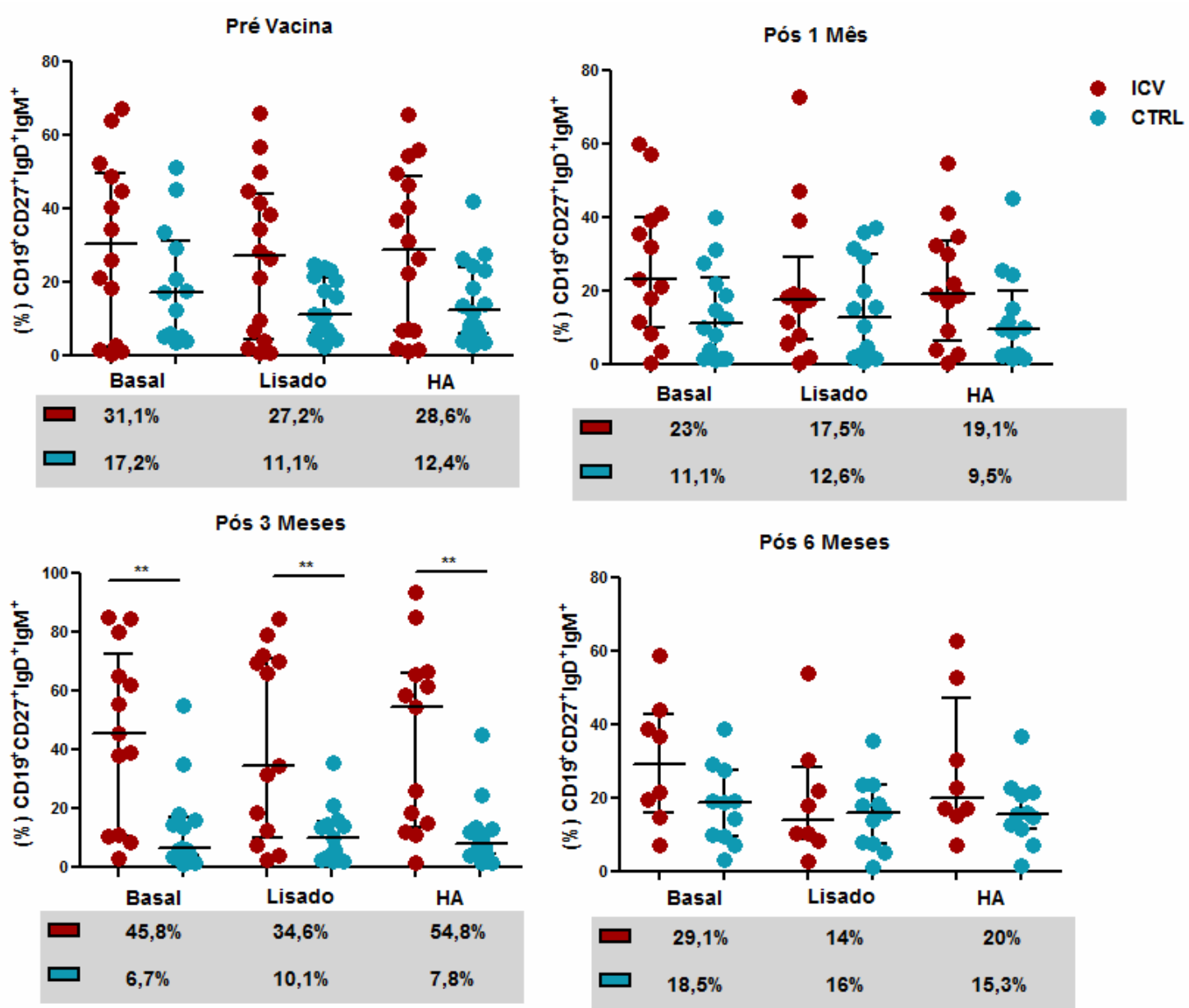

Figura 30: Frequência da Subpopulação de Linfócitos B de Zona Marginal Pré e Pós Vacinação contra Influenza - Comparação entre Pacientes e Controles. Os resultados foram expressos como mediana da porcentagem da frequência para a subpopulação de LB de zona marginal de indivíduos controles e pacientes com ICV, representados em azul e vermelho respectivamente. Comparação entre os tempos pré e pós 1, 3 e 6 meses, após a cultura com os estímulos Lisado Viral (lisado viral de Influenza na concentração de $30 \mathrm{ng} / \mathrm{mL}$ ) ou Peptídeo HA (peptídeo hemaglutinina de Influenza na concentração de $2,5 \mu \mathrm{g} / \mathrm{mL})$. Valores estatisticamente significantes foram representados por $(*)$ para $\mathrm{P}<0,05 ;(* *)$ para $\mathrm{P}<$ 0,01 .

A análise de $\mathrm{MZB}^{9}$ revelou que já no período pré vacinação, os pacientes apresentaram uma frequência superior desta subpopulação quando comparados aos controles, porém sendo este aumento estatisticamente significativo apenas 3 meses após a vacinação. Foi possível verificar que ao estímulo com lisado viral de Influenza houve um aumento de 3,4 vezes em relação aos controles no mesmo período e com o peptídeo HA, o aumento foi de 7 vezes ao observado nos controles nas mesmas condições. Por fim, no período pós 6 meses, esta diferença não foi mais observada. A figura 31

\footnotetext{
${ }^{9}$ MZB: Linfócito B de Zona Marginal
} 
descreve a cinética da frequência de MZB após a cultura com lisado viral e HA em indivíduos controles e pacientes com ICV nos períodos avaliados.
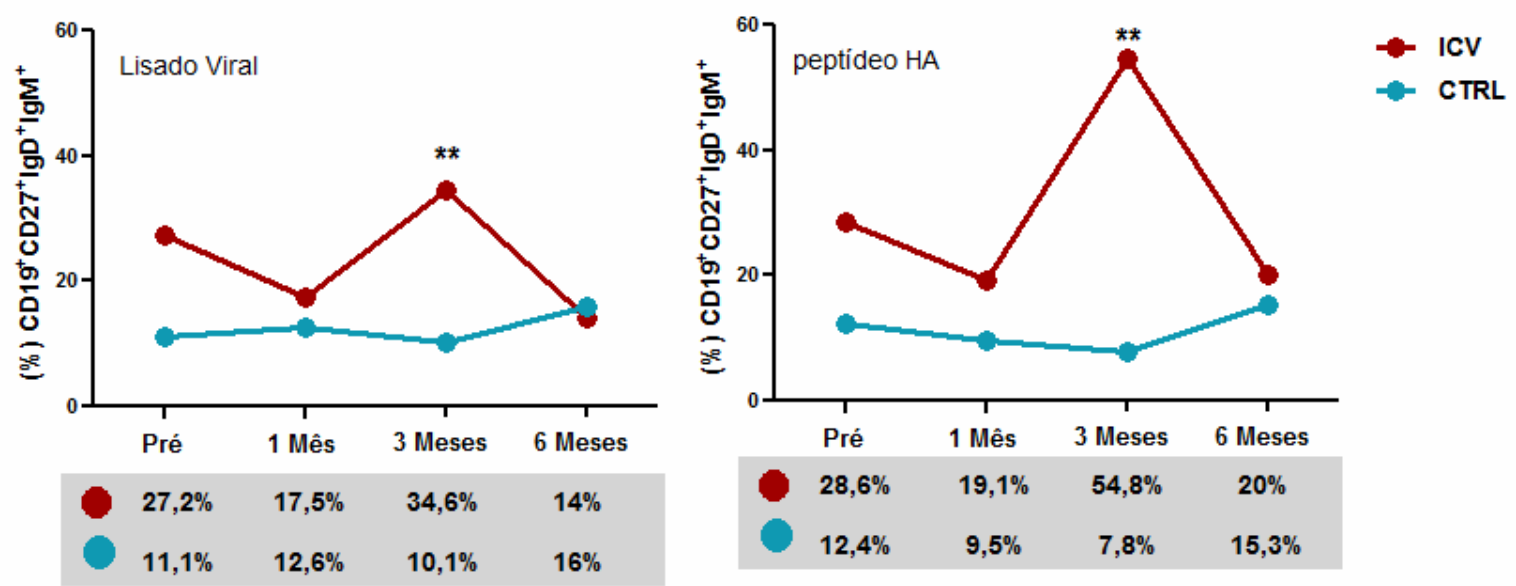

Figura 31: Cinética de LB de Zona Marginal Após Administração da Vacina de Influenza e Estimulação com Lisado Viral ou Peptídeo HA - Comparação entre ICV e Controles. Os resultados foram expressos como mediana da porcentagem de LB de zona marginal para pacientes com ICV e controles, no tempos: Pré Vacinação, Pós 1,3 e 6 Meses, após a cultura com os estímulos Lisado Viral (lisado viral de Influenza na concentração de $30 \mathrm{ng} / \mathrm{mL}$ ) ou Peptídeo HA (peptídeo hemaglutinina de Influenza na concentração de $2,5 \mu \mathrm{g} / \mathrm{mL}$ ). Valores estatisticamente significantes foram representados por $\left(^{*}\right)$ para $\mathrm{P}<0,05 ;(* *)$ para $\mathrm{P}<0,01$.

A seguir, a figura 32 descreve a comparação entre pacientes e controles quanto a frequência de $\mathrm{SMB}^{10}$.

${ }^{10}$ SMB: Linfócito B de Memória com Troca de Isotipo. 

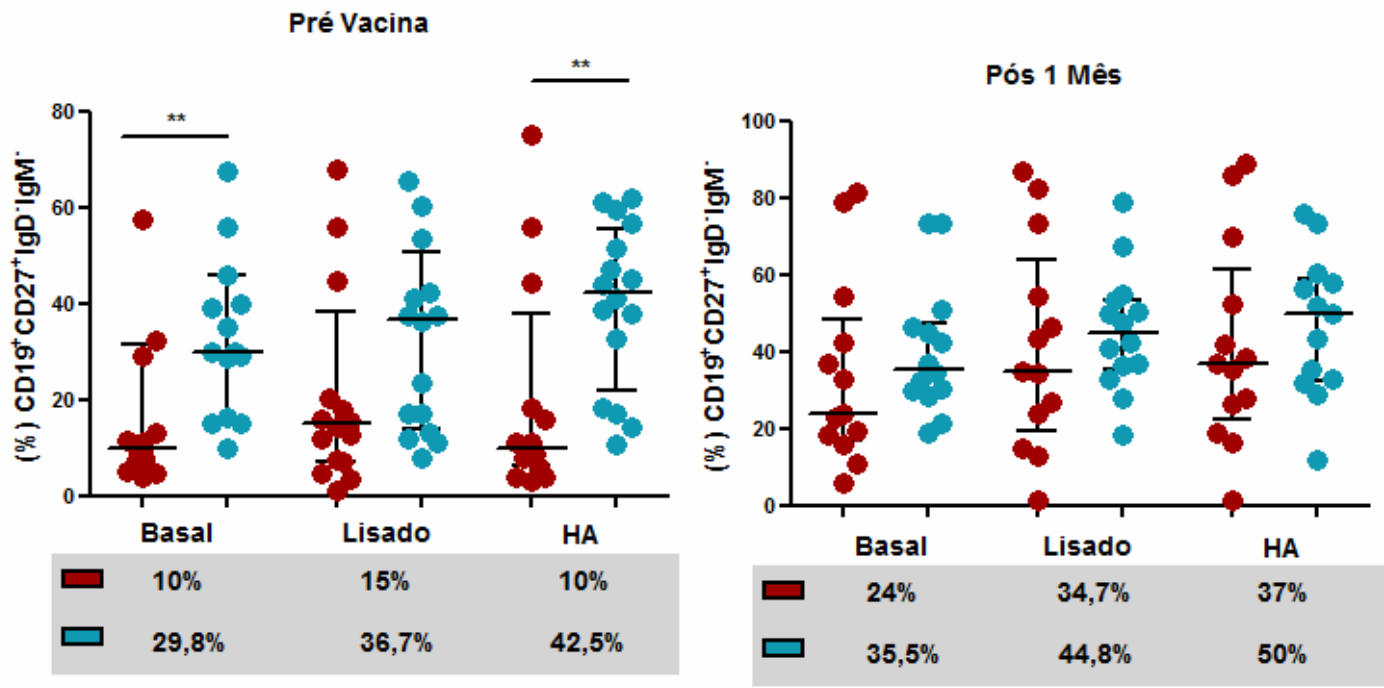

- ICV

- CTRL

Pós 3 Meses
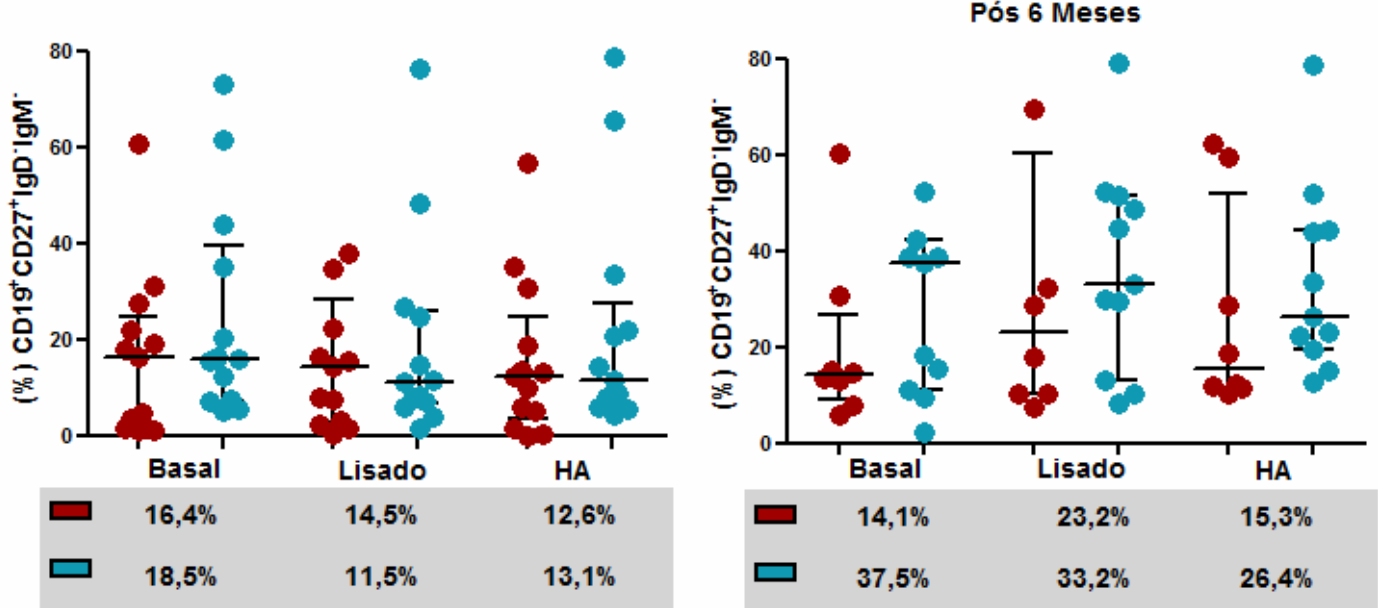

Figura 32: Frequência da Subpopulação de Linfócitos B de Memória com Troca de Isotipo Pré e Pós Vacinação contra Influenza - Comparação entre Pacientes e Controles. Os resultados foram expressos como mediana da porcentagem da freqüência para a subpopulação de LB de memória com troca de isotipo de indivíduos controles e pacientes com ICV, representados em azul e vermelho respectivamente. Comparação entre os tempos pré e pós 1, 3 e 6 meses, após a cultura com os estímulos Lisado Viral (lisado viral de Influenza na concentração de $30 \mathrm{ng} / \mathrm{mL}$ ) ou Peptídeo HA (peptídeo hemaglutinina de Influenza na concentração de $2,5 \mu \mathrm{g} / \mathrm{mL}$ ). Valores estatisticamente significantes foram representados por $(*)$ para $\mathrm{P}<0,05 ;(* *)$ para $\mathrm{P}<0,01$.

Em relação a subpopulação de $\mathrm{SMB}^{11}$, em todos os períodos estudados, foi possível verificar que os pacientes apresentaram frequências menores em relação ao grupo dos controles, sendo esta redução estatisticamente significativa já no período pré vacinação. Verificamos que sem estímulo (condição basal) os pacientes apresentaram uma

${ }^{11}$ SMB: Linfócito B de Memória com Troca de Isotipo. 
frequência de SMB 3 vezes menor que os controles e após a cultura com o peptídeo HA, esta diminuição foi em torno de 4,2 vezes quando comparados aos controles no mesmo período.

Após a administração das vacinas, verificamos que houve um aumento na frequência desta subpopulação para ambos os grupos, entretanto, os pacientes passaram a apresentar valores muito próximos dos encontrados para o grupo dos controles, não sendo possível verificar uma diferença estatística entre os grupos.

No terceiro mês após a vacinação, ambos os grupos apresentaram uma redução na frequência de SMB em todas as condições avaliadas e ao sexto mês, a expressão deste subtipo apresentou uma maior expressão no grupo dos controles, assim como o que foi observado no período pré vacinação, porém não observamos uma diferença estatisticamente significativa eles. Abaixo se encontra a descrição da cinética de SMB para pacientes e controles.
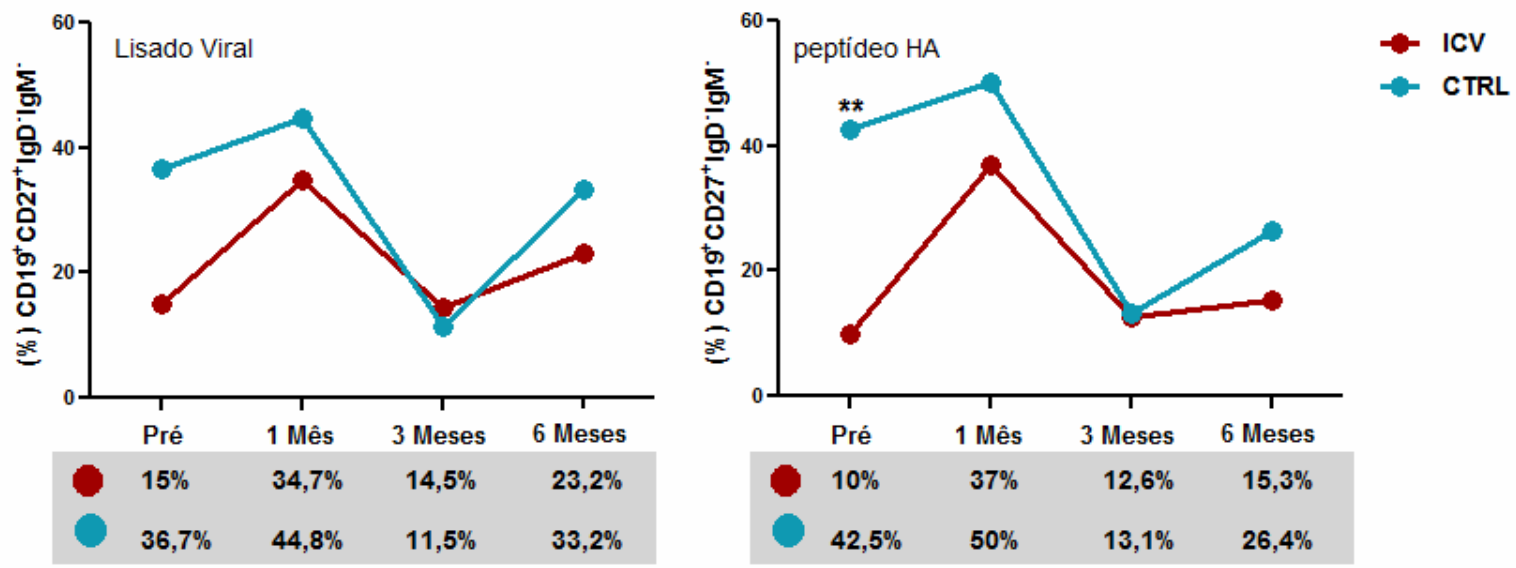

Figura 33: Cinética de LB de Memória com Troca de Isotipo Após Administração da Vacina de Influenza e Estimulação com Lisado Viral ou Peptídeo HA - Comparação entre ICV e Controles. Os resultados foram expressos como mediana da porcentagem de LB de memória com troca de isotipo para pacientes com ICV e controles, no tempos: Pré Vacinação, Pós 1,3 e 6 Meses, após a cultura com os estímulos Lisado Viral (lisado viral de Influenza na concentração de $30 \mathrm{ng} / \mathrm{mL}$ ) ou Peptídeo HA (peptídeo hemaglutinina de Influenza na concentração de $2,5 \mu \mathrm{g} / \mathrm{mL}$ ). Valores estatisticamente significantes foram representados por $(*)$ para $\mathrm{P}<0,05 ;(* *)$ para $\mathrm{P}<0,01$.

Por fim, foi realizada a comparação da frequência de plasmoblastos entre pacientes e controles e os resultados se encontram na figura 34. 

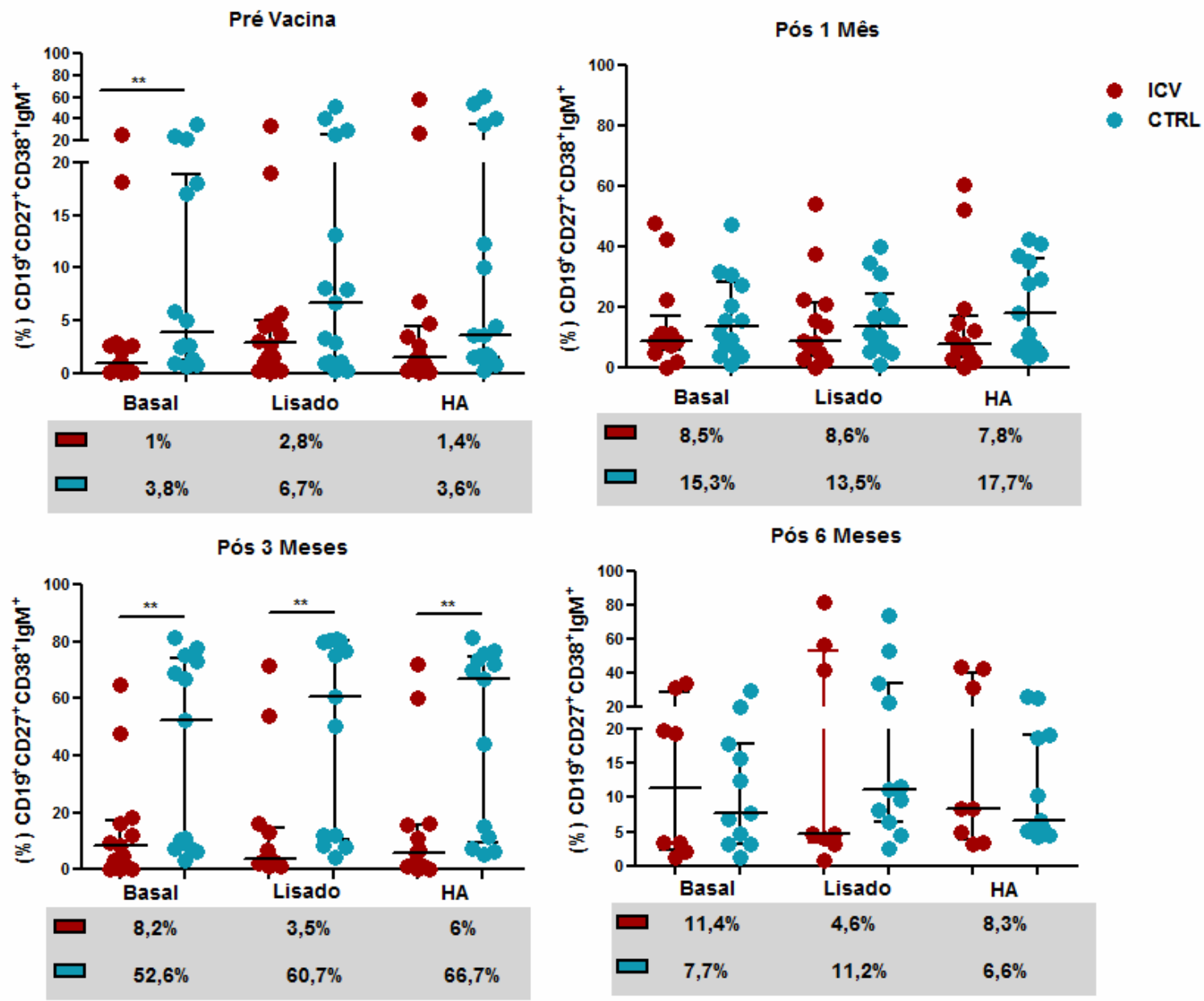

Figura 34: Frequência da Subpopulação de Plasmoblastos Pré e Pós Vacinação contra Influenza Comparação entre Pacientes e Controles. Os resultados foram expressos como mediana da porcentagem da frequiência para a subpopulação de plasmoblastos de indivíduos controles e pacientes com ICV, representados em azul e vermelho respectivamente. Comparação entre os tempos pré e pós 1, 3 e 6 meses, após a cultura com os estímulos Lisado Viral (lisado viral de Influenza na concentração de 30 ng/mL) ou Peptídeo HA (peptídeo hemaglutinina de Influenza na concentração de 2,5 $\mu \mathrm{g} / \mathrm{mL}$ ). Valores estatisticamente significantes foram representados por $(*)$ para $\mathrm{P}<0,05$; (**) para $\mathrm{P}<0,01$.

A comparação da subpopulação de PBL também revelou que os pacientes com ICV apresentaram frequências menores que os controles em todos os períodos avaliados. No período pré vacinação, os controles apresentaram uma freqüência 4 vezes superior aos pacientes na condição basal, sendo esta estatisticamente significativa.

Após 1 mês da administração da vacina, ambos os grupos aumentaram a expressão deste subtipo de LB e mesmo os pacientes apresentando frequências inferiores aos controles, não foram observadas diferenças entre os grupos para todas as condições avaliadas. Ao terceiro mês, podemos observar que os controles apresentaram a maior 
expressão de PBL após a vacinação e em contrapartida, os pacientes apresentaram uma queda, a qual foi estatisticamente significativa para todas as condições estudadas. Esta menor expressão de PBL nos pacientes foi 17,4 e 11,1 vezes abaixo do observado nos controles após a cultura com lisado viral e peptídeo HA respectivamente. No sexto mês, a expressão deste subtipo apresentou uma maior expressão no grupo dos controles, assim como o que foi observado no período pré vacinação, porém não observamos uma diferença estatisticamente significativa eles. A seguir, a figura 35 descreve a cinética da frequência de PBL para pacientes e controles nos períodos pré e pós vacinação.
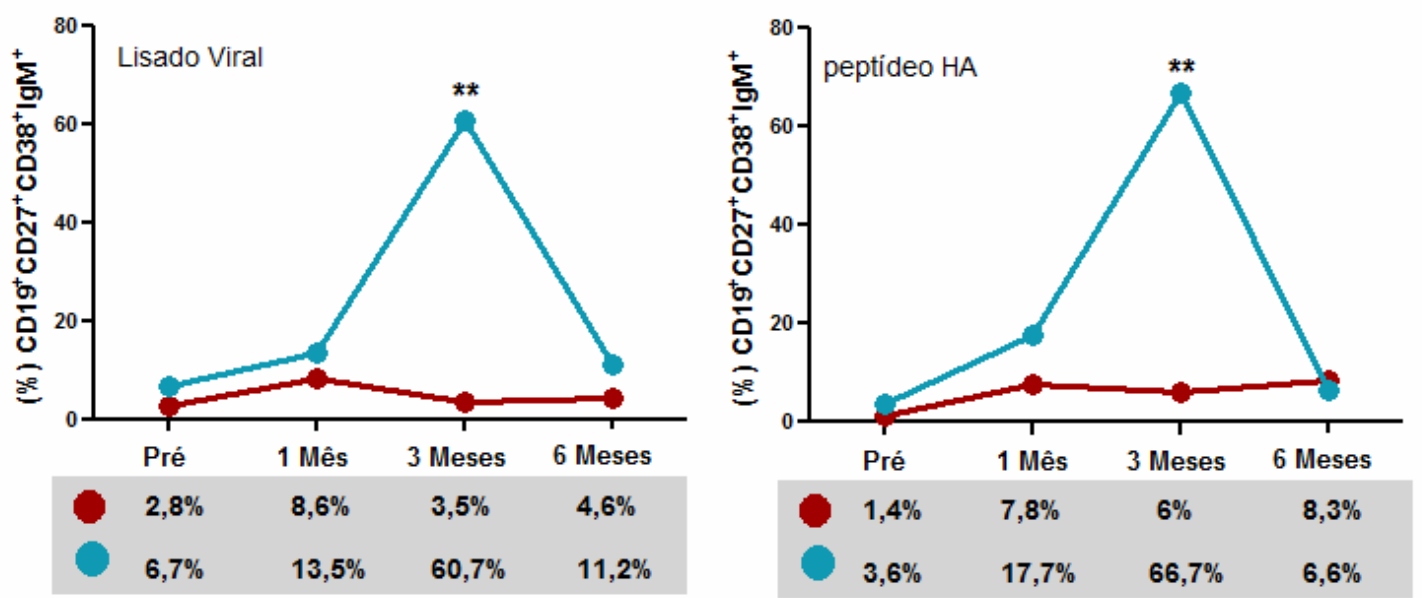

Figura 35: Cinética de Plasmoblastos Após Administração da Vacina de Influenza e Estimulação com Lisado Viral ou Peptídeo HA - Comparação entre ICV e Controles. Os resultados foram expressos como mediana da porcentagem de plasmoblastos para pacientes com ICV e controles, no tempos: Pré Vacinação, Pós 1,3 e 6 Meses, após a cultura com os estímulos Lisado Viral (lisado viral de Influenza na concentração de $30 \mathrm{ng} / \mathrm{mL}$ ) ou Peptídeo HA (peptídeo hemaglutinina de Influenza na concentração de $2,5 \mu \mathrm{g} / \mathrm{mL}$ ). Valores estatisticamente significantes foram representados por $\left(^{*}\right)$ para $\mathrm{P}<0,05 ;(* *)$ para $\mathrm{P}<0,01$.

\subsection{Classificação dos Pacientes de Acordo com o Tipo de Resposta Após a} Vacinação.

Ao observarmos que os pacientes apresentaram a maior expressão de SMB e PBL logo no primeiro mês da administração das vacinas, procuramos verificar uma possível correlação entre o aumento da frequência destes 2 subtipos de LB, o qual poderia nos auxiliar na subdivisão dos pacientes de acordo com o padrão de resposta após a vacinação, seja apenas pela produção de células B de memória ou também pela $\begin{array}{lllll}\text { produção } & \text { de células } & \text { B } & \text { efetoras. }\end{array}$ 
Analisamos a correlação entre a diferença da frequência de SMB nos períodos pós 1 mês menos o período pré vacinação com a diferença entre a frequência de PBL nos mesmos períodos e os resultados se encontram na figura 36.

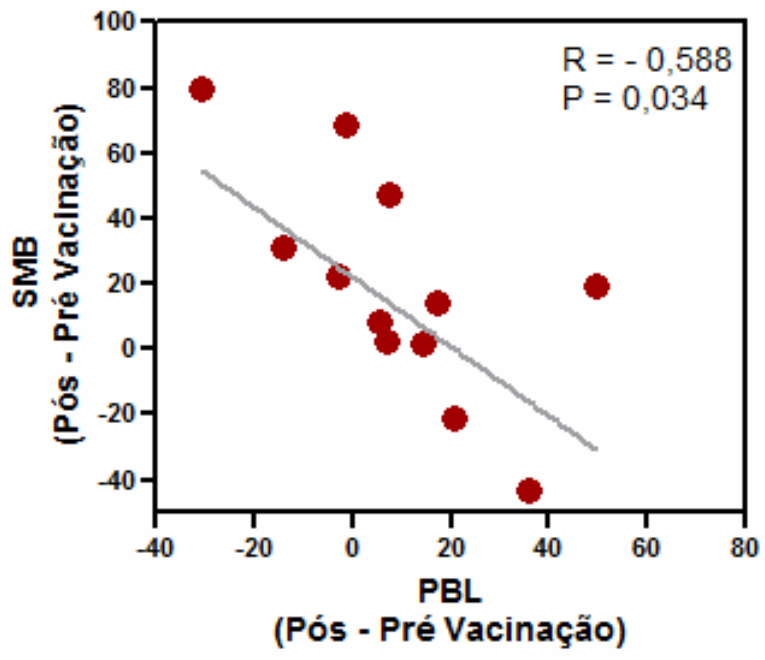

Figura 36: Correlação entre LB de Memória com Troca de Isotipo e Plasmoblastos nos Pacientes com ICV. Os resultados foram expressos como a diferença da frequência de SMB entre os períodos pós 1 mês e pré e a diferença da frequência de PBL nos mesmos períodos. Para ambos os subtipos foram considerados os valores obtidos após a estimulação com lisado viral de Influenza na concentração de 30 $\mathrm{ng} / \mathrm{mL}$.

Observamos uma correlação entre SMB e PBL no período pós 1 mês $(\mathrm{p}=0,034)$, assim a partir deste resultado, subdividimos os pacientes em três grupos de acordo com o tipo de resposta apresentada após a vacinação, a qual pode ser observado na tabela 6 e na figura 37.

Tabela 9: Classificação dos Pacientes de Acordo com o Perfil de Resposta Após a Vacinação.

\begin{tabular}{c|c|c|}
\hline \multicolumn{3}{|c|}{ PERFIL DE RESPOSTA APÓS A VACINAÇÃO } \\
\hline G1 & G2 & G3 \\
\hline T SMB e PBL após a vacinação. & $\uparrow$ SMB após a vacinação. & $\downarrow$ SMB e $\uparrow$ PBL após a vacinação \\
$\mathbf{N = 6 ( 4 6 \% )}$ & $\mathbf{N = 4 ( 3 1 \% )}$ & $\mathbf{N = 3 ( 2 3 \% )}$ \\
\hline
\end{tabular}

Classificação baseada na produção de SMB e PBL após 1 mês da administração das vacinas, onde foram consideradas as freqüências obtidas após a cultura com lisado viral de Influenza da concentração de 30 ng/mL. G1: pacientes que aumentaram a expressão de SMB e PBL após a vacinação; G2: pacientes que aumentaram a expressão apenas de SMB após a vacinação e G3: pacientes que não apresentaram aumento na expressão de SMB apenas para PBL.

SMB: linfócito B de memória com troca de isotipo.

PBL: plasmoblastos. 


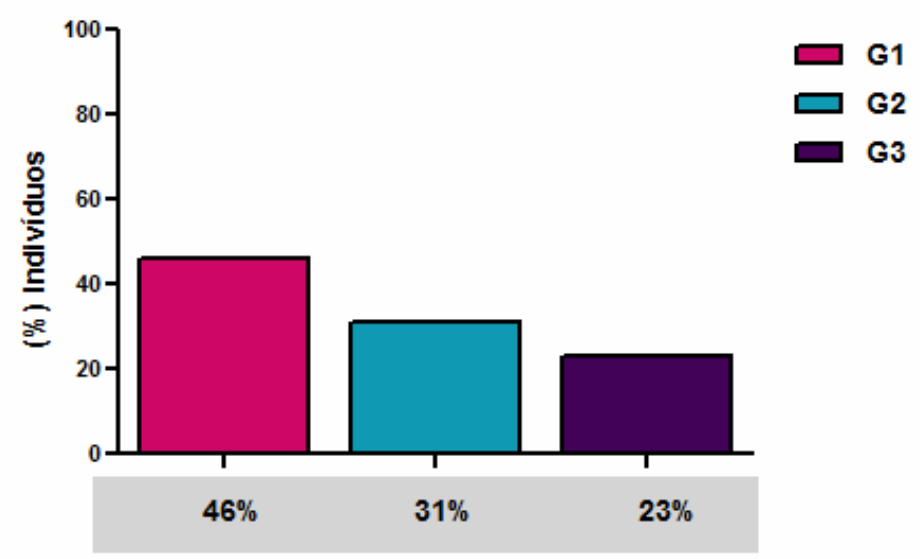

Figura 37: Classificação dos Pacientes de Acordo com o Perfil de Resposta Após a Vacinação. G1: pacientes que aumentaram a expressão de SMB e PBL após a vacinação; G2: pacientes que aumentaram a expressão apenas de SMB após a vacinação e G3: pacientes que não apresentaram aumento na expressão de SMB apenas para PBL.

SMB: linfócito B de memória com troca de isotipo.

PBL: plasmoblastos.

Observamos que dos 13 pacientes avaliados, a maioria (46\%) ficou classificado no grupo 1 (capazes de aumentar a expressão tanto de SMB quanto de PBL), seguido pelo grupo 2, pacientes que foram capazes de aumentar a expressão de SMB porém não conseguiram produzir PBL após a vacinação (31\%). Por fim, o grupo 3 compreendeu 23\% dos pacientes (capazes de apresentar aumento na expressão de PBL apenas).

A seguir na figura 38 foi feita a comparação entre a diferença no score de sintomas entre os períodos pós 1 mês e pré vacinação para cada um dos grupos classificados.

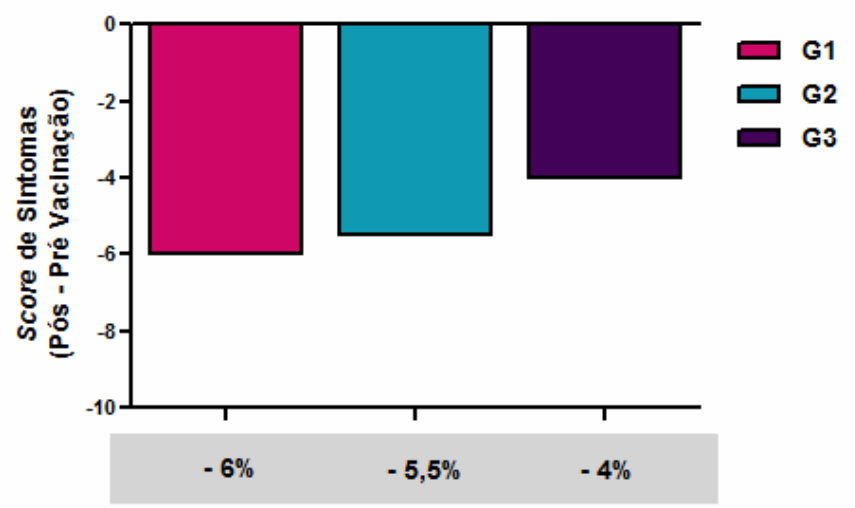

Figura 38: Avaliação Clínica Após a Classificação dos Pacientes de Acordo com o Perfil de Resposta Após a Vacinação. Os resultados representam a mediana da diferença da soma das pontuações dos 8 parâmetros do score de sintomas entre os períodos pós e pré vacinação. G1: pacientes que aumentaram a expressão de SMB e PBL após a vacinação; G2: pacientes que aumentaram a expressão apenas de SMB após a vacinação e G3: pacientes que não apresentaram aumento na expressão de SMB apenas para PBL.

SMB: linfócito B de memória com troca de isotipo.

PBL: plasmoblastos. 
Ao compararmos a avaliação clínica por meio da queda da pontuação do score de sintomas pós e pré vacinação para cada um dos grupos observamos que os pacientes classificados no G1 apresentaram a maior queda do score de sintomas após a vacinação, seguido dos pacientes classificados no G2.

Observamos que em relação à produção de anticorpos específicos após a vacinação, dos 13 pacientes classificados, apenas 3 foram capazes de desenvolver soroproteção para H1N1, sendo que 2 deles estão classificados no G1 e o outro no G2. Em relação à soroconversão para $\mathrm{H} 1 \mathrm{~N} 1$, apenas 1 paciente, classificado no G1, apresentou títulos de anticorpos específicos maiores que $1 / 40$.

Também foi realizada a classificação EUROclass destes pacientes, presente no anexo 18. 


\subsection{Dados Epidemiológicos e Clínicos}

O aparecimento das complicações clínicas associadas à ICV pode surgir em qualquer faixa etária e a qualquer momento da evolução da doença, sendo que algumas complicações já estão presentes ao diagnóstico.

Neste estudo, a mediana de idade dos pacientes com ICV ao início dos sintomas foi de 19 anos, sendo compatível com o relatado em outros estudos que apontam a idade de início mais prevalente a $2^{\mathrm{a}}$ e $3^{\mathrm{a}}$ décadas de vida (Park et al., 2008; Wehr et al., 2008; Cunningham-Rundles, 2010; Salzer, 2012).

Neste grupo de pacientes, verificamos que a mediana de idade ao diagnóstico foi de 33,4 anos, apontando um retardo no diagnóstico de 6 anos, sendo estes resultados compatíveis com outras coortes (Cunningham-Rundles, 2012; Gathmann, 2014). A falta de familiaridade e a dificuldade do reconhecimento precoce da ICV justificam esta observação e determina um retardo no início do tratamento adequado interferindo assim na qualidade de vida do paciente. Entretanto, fato positivo que chamou a atenção neste grupo de pacientes foi que em 2004, Kokron et al., estudando os pacientes desta mesma coorte, relatou um retardo de diagnóstico de 10 anos, indicando que nos últimos anos houve um avanço no reconhecimento e diagnóstico da doença em nosso meio.

Assim como relatado em outros trabalhos, nosso grupo de estudo também não apresentou predileção por gênero. Em relação às complicações clínicas que os pacientes com ICV podem apresentar, as manifestações autoimunes são as mais comuns. Sua prevalência nestes é estimada entre $20 \%$ e $50 \%$, sendo as citopenias autoimunes as mais observadas, entretanto, alguns pacientes desenvolveram citopenias, vitiligo, artrite reumatóide, alopécia, tireoidites, síndrome de Sjögren e doença celíaca-like (Michel et al., 2004; Carbone et al., 2004; Cunningham-Rundles et al., 2006; Lopes-da-Silva \& Rizzo, 2008; Ramirez-Vargas et al., 2013).

Nesta coorte, as doenças autoimunes estiveram presentes em $42,3 \%$ dos pacientes, sendo que as citopenias autoimunes, seguido de vitiligo foram as manifestações mais prevalentes. Estes dados foram semelhantes ao observado em outras coortes (Quinti et al., 2007; Cunningham-Rundles, 2010; Morio, 2012). 
A presença de esplenomegalia também é comum em pacientes com ICV, podendo ser o reflexo da desregulação imunológica característica da doença. Nesta coorte foi observado que 38,5\% dos pacientes apresentaram esta manifestação clínica. Quanto à linfadenopatia, observamos uma prevalência de 34,6\%. Estes resultados divergem do observado em 2008 por Chapel et al., que avaliando uma coorte de 334 pacientes com ICV, apenas $15 \%$ dos pacientes apresentaram linfadenopatia, mas é semelhante a prevalência de esplenomegalia (30\%). Estes dados sugerem que os pacientes com ICV deste estudo apresentaram maior prevalência de uma linfoproliferação benigna do que a observada em outras coortes. Novos estudos serão necessários para investigar a causa deste achado.

Pacientes com ICV tem maior susceptibilidade a desenvolverem doenças malignas durante o curso da doença. Em torno de $15 \%$ dos pacientes desenvolvem algum tipo de câncer, sendo os mais comuns os linfomas não Hodgkin e os carcinomas gástricos (Cunningham-Rundles, 2010). Nos pacientes estudados neste trabalho observamos menor prevalência (4\%), provavelmente decorrente dos critérios de seleção dos pacientes deste estudo. Quando avaliamos a coorte dos pacientes com ICV acompanhados no nosso serviço, a prevalência de doenças malignas está em torno de $15 \%$.

A granulomatose é relatada em torno de $10 \%$ a $20 \%$ dos pacientes com ICV, podendo manifestar-se em diferentes órgãos, mas principalmente em pulmão e linfonodos e geralmente é mais comum nos pacientes adultos (Park et al., 2008; Salzer et al., 2012). Não observamos esta complicação clínica em nosso estudo, contrastando com Chapel et al. (2008) que verificaram que a frequência de granulomatose estava em torno de $8 \%$ em uma coorte de 334 pacientes europeus e também com CunninghamRundles (2010) que verificaram nos pacientes americanos frequências similares.

A atopia esteve presente em 38,5\% dos pacientes, sendo a rinite a manifestação mais prevalente. Estes dados são compatíveis ao relatado em outras coortes (Kindi et al., 2013; Agondi et al., 2013).

Porém dentre todas as manifestações clínicas da ICV, as infecções recorrentes são consideradas as mais prevalentes, ocorrendo em 98\% dos pacientes (CunninghamRundles, 1999; Kokron et al., 2004; Salzer et al., 2012). O comprometimento do sistema gastrointestinal é bastante prevalente, mas o trato respiratório é geralmente o mais afetado, ocasionando bronquites, sinusites, otites e pneumonias. 
Nesta coorte, foi verificado que $81 \%$ dos pacientes apresentaram infecções recorrentes, concordando com Cunningham-Rundles (2010) que verificou a mesma prevalência. As sinusites e as pneumonias foram as manifestações mais relatadas.

Em decorrência das infecções pulmonares de repetição, muitos pacientes com ICV desenvolvem bronquiectasias. Nesta coorte, sua prevalência foi de 54\%. Em 2010, Touw et al., em uma revisão de 26 trabalhos, verificou que sua prevalência em pacientes com ICV varia em torno de $29 \%$ a $79 \%$, nos mostrando que nossos resultados estão de acordo com a literatura. Estas sequelas pulmonares podem ser justificadas pelo retardo do diagnóstico que estes pacientes apresentam, reafirmando assim a necessidade do tratamento precoce da ICV (Costa Carvalho et al., 2002).

A maior causa de hospitalizações e uso de antibioticoterapia em pacientes com ICV é decorrente das infecções das vias aéreas (Gorczynski, 2001), assim, a avaliação mais detalhada das manifestações infecciosas foi realizada por meio da aplicação de um score de sintomas modificado de Yarmohammadi et al., (2008), onde primeiramente avaliamos os períodos pré e o período posterior ao início do tratamento com IVIg e em um segundo momento, o período de 12 meses após vacinação específica para Influenza, H1N1 e S. pneumoniae.

Os benefícios decorrentes do uso de imunoglobulina humana em pacientes com ICV já são bem documentados, sendo principalmente associados à diminuição das infecções respiratórias e bronquiectasias (Farrant et al., 1985; Esolen et al., 1992).

Como já era esperada, a comparação entre os períodos pré e pós tratamento com a reposição das imunoglobulinas revelou haver uma redução significativa na pontuação do score de sintomas.

Nobre et al., (2012) avaliando o impacto do tratamento com IVIg sobre o número de infecções em pacientes com deficiências de anticorpos observou considerável redução de pneumonias e otites após o início do tratamento com a reposição de imunoglobulinas. Giovanneti et al., 2007, entretanto verificou que em relação as bronquiectasias, por se tratarem de lesões pulmonares de caráter definitivo, não apresentaram regressão após o início do tratamento adequado.

Farrant et al., (1989) relataram que as sinusites são as infecções das vias aéreas superiores mais prevalentes e mesmo com a reposição de imunoglobulinas seu controle é bastante difícil, neste sentido, consideramos que a vacinação para Influenza e $S$. pneumoniae represente grande auxílio no seu controle. 
Após a vacinação, observamos uma redução adicional significativa na pontuação do score de sintomas. Estes achados nos mostram que mesmo apresentando defeitos em vários componentes do sistema imune, a imunização em pacientes com ICV determinou uma melhora clínica considerável.

Devido ao fato de que nem todos os pacientes tomaram as três vacinas, nos questionamos se os pacientes que foram imunizados apenas com a vacina InfluenzaH1N1 estiveram menos protegidos que os pacientes que receberam também a vacina contra Influenza-H2N3 e estes dos que receberam as três vacinas. Em 2007, Goldacker et al., avaliou a resposta vacinal de 21 pacientes após a imunização simultânea para as vacinas contra tétano, difteria, H. influenza, S. pneumoniae e hepatites A e B e verificou que a vacinação simultânea e a interação entre as vacinas não apresentaram riscos aos pacientes, por conta de serem vacinas formuladas com patógenos mortos, mas não avaliou uma possível diferença de proteção nos pacientes que receberam mais de uma vacina.

Neste sentido, fizemos a avaliação do score de sintomas, porém levando em consideração o número de vacinas a que os pacientes receberam e não observamos diferença no score de sintomas nos pacientes que receberam mais de uma vacina quando comparados aos que receberam apenas uma.

\subsection{Dosagem de Imunoglobulinas Séricas e Produção de Anticorpos Específicos}

A redução na concentração sérica de $\operatorname{IgG}$ associada à diminuição de $\operatorname{IgM}$ e/ou $\operatorname{IgA}$ é uma das características principais que auxiliam o médico a definir a Imunodeficiência Comum Variável. Nos pacientes que apresentarem concentração sérica de IgG menor que $200 \mathrm{mg} / \mathrm{dL}$ ou pacientes cuja concentração sérica de IgG está entre 200 a 500 $\mathrm{mg} / \mathrm{dL}$ associado a infecções recorrentes, se faz necessária a reposição de imunoglobulinas (Hausser et al., 1983; Spickett et al., 1990; Berger, 2008).

Como esperado, após o início do tratamento com IVIg, observamos um aumento significativo nos níveis séricos de $\operatorname{IgG}$ cujos benefícios ao paciente com ICV são consideráveis, principalmente na diminuição das infecções do trato respiratório, manifestação clínica presente na maioria dos pacientes (Busse et al., 2002).

A dosagem de anticorpos específicos para Influenza revelou que tanto pacientes 
quanto controles já apresentavam níveis de anticorpos específicos no período pré vacinação.

Uma das possíveis explicações deste resultado nos controles, seria a vacinação e/ou contato prévio, uma vez que todos eles já haviam recebido a vacina contra o vírus Influenza no ano anterior, além de que dos 16 controles analisados, 12 são profissionais da área da saúde e estão diariamente expostos ao contato do vírus.

Em 2012, Kubota-Koketsu et al., analisando lotes de imunoglobulinas dos períodos de 1993 a 2010, verificaram baixos títulos do vírus da gripe asiática e concluíram que os títulos de anticorpos específicos para Influenza se correlacionavam com a história de exposição ao vírus, seja por conta das epidemias ou devido as campanhas de vacinação.

Diante disto, associado à pesquisa de anticorpos para Influenza na alíquota da imunoglobulina utilizada, concluímos que os altos títulos de anticorpos específicos para os sorotipos A e B de Influenza encontrados nos pacientes, provém da gamaglobulina. Este resultado corrobora a hipótese de Chovancova et al., (2011) que a avaliação da produção de anticorpos após a vacinação é dificultada devido ao tratamento com a reposição de imunoglobulinas.

Após a vacinação, verificamos um aumento na concentração sérica de $\operatorname{IgG}$ específica de ambos os sorotipos tanto em controles quanto pacientes, com a produção máxima ocorrendo por volta de 1 a 3 meses após a vacinação. Entretanto, este aumento foi significativo apenas nos controles.

Comparando pacientes e controles quanto à resposta para Influenza A e B, observamos que diferente do sorotipo $\mathrm{B}$, em que houve aumento significante em todos os tempos, no sorotipo A, a maior resposta foi observada apenas no período pós 3 meses.

Segundo a Agência Européia de Medicamentos (1996), um dos critérios da avaliação da imunogenicidade de vacinas contra Influenza é que estas devem apresentar uma taxa de soroproteção acima de $70 \%$ em indivíduos entre a faixa etária de 18 a 60 anos. Verificamos que ambos os grupos apresentaram soroproteção para os sorotipos A e B acima desta taxa predefinida, entretanto observamos que logo no primeiro mês após a vacinação, todos os controles já estavam soroprotegidos e esta soroproteção foi mantida até o sexto mês para os dois sorotipos. $\mathrm{O}$ mesmo não foi observado nos pacientes, que mesmo desenvolvendo considerável alta na taxa de soroproteção para 
ambos os sorotipos, apresentou valores inferiores aos observados nos controles.

Recentemente, S. Van Assen et al., (2011) verificaram que mesmo após a vacinação contra Influenza, pacientes com ICV não apresentaram IgG sérica específica em títulos considerados protetores, além de desenvolverem menor taxa de soroproteção que os controles, assim, acreditamos que devido a alta concentração sérica observada na alíquota de imunoglobulina que os pacientes fizeram uso durante o período do estudo, as diferenças observadas entre ambos os grupos possam ser ainda mais expressivas.

Quanto ao H1N1, em 2009, a apreensão em relação ao número de hospitalizações e mortes em pessoas que apresentam algum tipo de imunossupressão levou a necessidade e a pressa na formulação de uma vacina capaz de conferir proteção. Por conta disso, a indicação da vacinação em pacientes com imunodeficiências foi baseada na experiência com a administração de outras vacinas de Influenza, devido ao fato destas também serem inativadas (Durando et al., 2008; Zand, 2008; Lavallade et al., 2011; Pedersen et al., 2011).

Considerando que os pacientes deste estudo ainda não haviam recebido a vacina e teoricamente não tinham sido expostos ao vírus, incluímos a avaliação dos anticorpos específicos para $\mathrm{H} 1 \mathrm{~N} 1$, para poder avaliar a capacidade de resposta frente a um antígeno novo.

Assim como verificado para os sorotipos A e B de Influenza, três pacientes já apresentavam títulos protetores de IgG anti-H1N1 no período pré vacinação, indicando a possibilidade de um contato prévio. Já no caso dos controles, os altos títulos de anticorpos específicos já no período pré vacinação pode ser decorrente da campanha de vacinação realizada no ano anterior, quando a vacina contra H1N1 foi indicada aos profissionais da área da saúde, que correspondem a grande parte deste grupo.

Em 2009, Yunoki et al., analisando 5 lotes de imunoglobulinas de um mesmo fabricante, verificaram que todos apresentaram títulos protetores de anticorpos específicos para $\mathrm{H} 1 \mathrm{~N} 1$, indicando que os controles saudáveis utilizados para a fabricação dos lotes já haviam entrado em contato com o vírus. Entretanto, no mesmo ano, Pedersen et al., (2011) estudando a resposta humoral e celular contra o vírus da gripe suína em 3 pacientes com ICV, constataram que a alíquota de imunoglobulina que os pacientes receberam não apresentavam anticorpos específicos para H1N1. Acreditamos que no nosso caso, possivelmente os 3 pacientes que já apresentavam IgG 
específico no período pré vacinação já tivessem sido expostos ao vírus, pois caso houvessem anticorpos específicos na imunoglobulina que receberam, todos os outros pacientes também apresentariam títulos positivos.

Após a vacinação, verificamos que a maioria dos pacientes não apresentou um aumento estatisticamente significante de IgG específica para H1N1, em nenhum dos tempos avaliados. Os três pacientes que apresentaram nível sérico acima do limiar já no período pré vacinação, mantiveram os altos títulos até o sexto mês. Contrastando com os pacientes, todos os controles apresentavam títulos acima do limiar logo no primeiro mês, mantendo-os até o sexto mês após a vacinação e determinando a diferença estatística observada em todos os períodos avaliados.

A análise da soroproteção para H1N1 revelou que apenas os controles apresentaram taxas acima do limiar, sendo que no terceiro mês, todos apresentaram soroproteção que foi mantida até o sexto mês. Em relação aos pacientes, a maior taxa de soroproteção foi observada no primeiro mês após a vacinação, porém, estes valores se encontraram muito abaixo do valor preestabelecido pela Agencia Europeia de Medicamentos, segundo a qual em torno de no mínimo $70 \%$ dos indivíduos dentro da faixa etária do estudo deveriam apresentar título igual ou superior a $1 / 40$, por conta disto a comparação entre os grupos revelou haver uma diferença significativa em todos os períodos avaliados.

A análise da soroconversão também foi avaliada e pudemos observar que os controles apresentaram maior taxa que os pacientes em todos os períodos estudados, entretanto, em ambos os grupos a frequência de soroconversão foi baixa, não sendo possível verificar uma diferença entre pacientes e controles.

Assim como nós, S. Van Assen et al., (2011), estudando a resposta celular e humoral contra H1N1 em 15 pacientes com ICV, a qual receberam uma única dose da vacina, também observou uma menor taxa de soroproteção e soroconversão que os controles.

Pedersen et al., (2011) também estudando a resposta celular e humoral de 3 pacientes com ICV pré e pós vacinação contra $\mathrm{H} 1 \mathrm{~N} 1$, verificaram que a maior produção de anticorpos específicos em pacientes com ICV ocorreu por volta da terceira semana após a administração de uma segunda dose da vacina. No mesmo ano, diversos trabalhos começaram a demonstrar que para a vacina contra $\mathrm{H} 1 \mathrm{~N} 1$ ser eficaz em pacientes imunocomprometidos, ela deveria ser administrada em 2 doses (De Lavallade et al., 2011; Crum-Cianflone et al., 2011). 
Em 2011, Lavallade et al., também avaliando a reposta celular e humoral de 97 pacientes imunocomprometidos, comparou as taxas de soroproteção e soroconversão de pacientes que receberam 1 dose da vacina contra $\mathrm{H} 1 \mathrm{~N} 1$ dos que receberam as duas doses e verificou que entre os pacientes que receberam apenas 1 dose da vacina, $35,7 \%$ soroconverteram e 39,3\% desenvolveram soroproteção, entretanto os pacientes que receberam as duas doses da vacina $64,3 \%$ foram capazes de soroconverter e $67,9 \%$ desenvolveram soroproteção, confirmando a necessidade da administração de duas doses da vacina contra $\mathrm{H} 1 \mathrm{~N} 1$ em pacientes imunocomprometidos.

Assim, acreditamos que pelo fato de a campanha de vacinação realizada no Brasil ter preconizado a administração de apenas 1 dose da vacina, esta pode não ter sido suficiente para conferir uma proteção humoral adequada para esses pacientes.

Em cerca de $90 \%$ dos pacientes com ICV, o S. pneumoniae é o causador de infecções sinopulmonares principalmente, mas também meningites e sepse, sendo o agente etiológico mais comumente associado a infecções do trato respiratório em adultos, mas também em pacientes com ICV (Hong et al., 2010; Salzer et al., 2013).

Alguns fatores de risco têm sido associados como a baixa produção de anticorpos específicos aos sorotipos, nível sérico de IgA e frequência de células B de memória, entretanto os mecanismos exatos que medeiam a baixa produção de anticorpos específicos aos sorotipos do $S$. pneumoniae e a maior susceptibilidade verificada nos pacientes com ICV ainda não estão bem definidos (Hong et al., 2010; Cavaliere et al., 2013).

Em 1990, Taunay et al., isolaram as cepas de S. pneumoniae de 1000 amostras de líquido cefalorraquidiano coletadas entre os anos de 1977 a 1988 pelo Instituto Adolfo Lutz e verificaram que os sorotipos 1, 3, 4, 5, 8, 12F, 14, 19F, 23F e 34 eram os mais prevalentes na cidade de São Paulo. Em 2009, no Instituto da Criança, Faria et al., padronizou a técnica de ELISA para a detecção de anticorpos IgG específicos para os sorotipos $1,4,5,6 \mathrm{~B}, 7 \mathrm{~F}, 9 \mathrm{~V}, 14,18 \mathrm{C}, 19 \mathrm{~F}$ e $23 \mathrm{~F}$, na qual nos baseamos para a avaliação da concentração sérica de $\operatorname{IgG}$ específicos nos períodos pré e pós vacinação.

Observamos que nestes pacientes, 2 mantiveram os títulos altos de IgG específicos verificados no período pré vacinação, que poderiam ser resultantes de uma transmissão passiva por meio da infusão de imunoglobulinas, vacinação ou até mesmo um contato prévio. Os outros 2 pacientes estudados, entretanto, mantiveram as baixas concentrações para todos os sorotipos testados em todos os períodos após a vacinação, além disso 
também observamos que eles apresentaram uma baixa expressão de LB de zona marginal.

O papel crucial que o receptor do tipo Toll 2 (TLR-2) apresenta na prevenção da infecção por S. pneumoniae já está bem estabelecido, uma vez que polimorfismos neste receptor aumentam a susceptibilidade da infecção em humanos (Lorenze et al., 2000).

Em 2010, Hong et al., estudando a resposta imunológica após a vacinação contra $S$. pneumoniae de 14 pacientes com ICV, observaram que apenas os monócitos eram capazes de produzir IL-6 e TNF- $\alpha$ e em concentrações muito inferiores ao observado nos controles, sugerindo um defeito na sinalização de TLR-2, que foi confirmada posteriormente.

A citocina IL-6 apresenta papel importante na proliferação e diferenciação de LB, principalmente em relação a subpopulação de LB de zona marginal, célula B crítica na produção de anticorpos contra polissacarídeos (Hong et al., 2010), assim, acreditamos que os pacientes que não foram capazes de responder a vacina possam apresentar algum defeito no TLR-2 que levaria a uma menor proliferação e diferenciação de LB de zona marginal, resultando na baixa produção de anticorpos específicos aos sorotipos e expressão de LB de zona marginal, entretanto, ressaltamos a necessidade de novos estudos com um número maior de pacientes para que possa ser investigada a causa deste achado.

\subsection{Expressão das Subpopulações de Linfócitos B}

A busca de semelhanças entre os pacientes com ICV cada vez mais tem se tornado necessária, a fim de auxiliar o clínico tanto no monitoramento da doença assim como na busca de possíveis marcadores prognósticos.

Após a demonstração de anormalidades no compartimento de LB em pacientes com Síndrome de HiperIgM ligada ao cromossomo X, vários estudos começaram a ser realizados em pacientes com ICV (Sneller, 2001; Ko et al., 2005).

Contrastando com indivíduos saudáveis que com o decorrer dos anos apresentam uma considerável redução na frequência de LB naive e aumento gradativo das populações de $\mathrm{MZB}^{12}$ e $\mathrm{SMB}^{13}$, pacientes com ICV apresentam um aumento da

\footnotetext{
${ }^{12}$ MZB: Linfócito B de Zona Marginal

${ }^{13}$ SMB: Linfócito B de Memória com Troca de Isotipo
} 
frequência da subpopulação naive e redução das subpopulações de memória e de plasmoblastos (Wehr et al., 2008; Lawrence, 2009; Mouilot et al., 2010; Vlková et al., 2010; Morbach et al., 2010).

Em decorrência desses trabalhos, três modelos de classificação baseados na caracterização das subpopulações de LB foram propostos: as classificações de Freiburg, Paris e EUROclass.

Pedreschi et al., (2011) analisando uma coorte de 70 pacientes, verificaram divergências em relação as frequências de algumas subpopulações de LB e a associação destas subpopulações com as manifestações clínicas presentes nos pacientes brasileiros, contrastando com os trabalhos europeus já descritos. Assim, as três classificações propostas não se mostraram adequadas e a inserção de novos parâmetros imunológicos e clínicos foram sugeridos para que se pudesse formular um novo modelo classificatório onde pacientes brasileiros pudessem ser contemplados.

Durante os últimos anos, como pode ser observado, vários estudos descreveram as diferenças entre as frequências dos subtipos de LB, sempre comparando pacientes com indivíduos saudáveis, porém a cinética destas células após o encontro com antígenos específicos tem sido pouco explorada (Chovancova et al., 2011).

Assim, ao observarmos a considerável melhora clínica depois da vacinação, apesar da não produção de anticorpos específicos, nos questionamos sobre o possível papel das subpopulações dos LB na diminuição do número de infecções do trato respiratório.

Diante disso nosso principal objetivo foi verificar a cinética dos subtipos de LB frente a antígenos proteicos após a vacinação contra Influenza.

Optamos por analisar 4 populações de LB: LB naive; LB de zona marginal (MZB); LB de memória com troca de isotipo (SMB) e plasmoblastos (PBL).

Ao avaliarmos a cinética dos subtipos no grupo controle verificamos que após 1 mês da vacinação, a população de LB naive caiu e no mesmo período as populações de memória tiveram aumento de frequência, podendo este resultado ser justificado pela a maturação dos LB desencadeada pelo encontro antigênico (Agenes et al., 2000).

Acreditamos que a reduzida frequência de MZB possa ser explicada pelo fato desta subpopulação ser associada à resposta contra antígenos polissacarídicos. Em contrapartida, a resposta para antígenos proteicos, como no caso contra o vírus Influenza, é determinada principalmente pela ação dos linfócitos $\mathrm{B}$ de memória com $\begin{array}{lllll}\text { troca de } & \text { (Haymore } & \text { isotipo }\end{array}$ 
Quanto ao fato do aumento da subpopulação de SMB ocorrer por volta de 1 mês após a vacinação, Pinna et al., (2009) também verificaram que esta subpopulação apresentou aumento de frequência por volta do décimo quarto dia após a vacinação contra Influenza sazonal em 14 indivíduos e que foi mantida até 30 dias após a vacinação, decaindo posteriormente.

Notamos que à medida que as frequências das subpopulações de memória diminuíram por volta do terceiro mês após a vacinação, a população de plasmoblastos passou a ser mais frequente e ambas voltaram aos níveis do período pré vacinação após 6 meses.

Entretanto, ao analisar a cinética das subpopulações de LB no grupo de pacientes, verificamos que após 1 mês da vacinação houve um aumento nas subpopulações naive, SMB e plasmoblastos, sendo significativo para as duas últimas subpopulações.

No terceiro mês após a vacinação, a população de LB naive se manteve elevada como observado ao primeiro mês, as populações de SMB e PBL decaíram bruscamente e em contrapartida, a subpopulação de MZB apresentou um aumento significativo em relação ao mês anterior, tanto ao estímulo do lisado viral e do peptídeo há quanto na condição basal.

Também realizamos a comparação entre as frequências dos subtipos de LB de pacientes e controles em todos os períodos e estímulos estudados e neste trabalho, os pacientes com ICV apresentaram um aumento da frequência de $\mathrm{MZB}^{14}$ estatisticamente significativo após 3 meses de vacinação, tanto estimulados com lisado viral e peptídeo HA quanto na condição basal quando comparado aos controles.

O mesmo não foi observado para as outras subpopulações, onde os controles apresentaram frequências maiores, sendo significativo no período pré vacinação para SMB, PBL e LB naive e após o terceiro mês de vacinação para a população de PBL, além disso esta subpopulação esteve reduzida nos pacientes em todos os tempos quando comparados aos controles, mesmo tendo apresentado um aumento discreto após a vacinação. Estes resultados reforçam a presença de distúrbios funcionais de LB relatados em pacientes com ICV.

A administração de vacinas contra antígenos proteicos e polissacarídicos tem demonstrado menor eficácia em relação à produção de anticorpos nos pacientes com

\footnotetext{
${ }^{14}$ MZB: Linfócito B de Zona Marginal.
} 
ICV quando comparados a controles saudáveis (Goldacker et al., 2007; Rezaei et al., 2008).

Em decorrência da deficiente produção de anticorpos específicos e baixa expressão das subpopulações de SMB e $\mathrm{PBL}^{15}$, a considerável melhora clínica que os pacientes apresentaram poderia ser explicada pela ação dos linfócitos $\mathrm{T}$, assim como verificado por Pedersen et al., (2011), que verificou uma resposta específica mediada por linfócitos $\mathrm{T} \mathrm{CD}^{+}$no perfil Th1 para Influenza após a vacinação,.

Porém, no mesmo ano, Van Assen et al., (2011), estudando 15 pacientes com ICV e 15 controles saudáveis, verificou que tanto a resposta celular quanto humoral contra Influenza foi bem menor no grupo de pacientes do que nos controles, mas não ausente.

Acredita-se que os linfócitos B imaturos dos pacientes com ICV, após a estimulação antigênica e na presença coestimulatória de linfócitos $T$, apresentam diferenciação tardia, resultando em células $\mathrm{B}$ em número normal, compostas principalmente por células naive e que não apresentam capacidade funcional (Ko et al., 2005).

Outra justificativa seria que a falha em componentes envolvidos na apresentação e coestimulação dos LB possam ser responsáveis pela sua deficiente diferenciação na tentativa de responderem contra o vírus Influenza (Thon et al., 1997).

Sabe-se que as células dendríticas são as principais indutoras das respostas $\mathrm{T}$ dependentes, além de também serem responsáveis pela diferenciação do LB naive para plasmócito (Jego et al., 2003). Diversos trabalhos têm demonstrado que pacientes com ICV apresentam defeitos na diferenciação e ativação de células dendríticas, assim como na expressão da molécula coestimulatória CD40. Como conseqüência destas alterações, é verificado a falha da ativação do LB e consequentemente da troca de isotipo (Banchereau e Steinman, 1998; Pinchuk et al., 1996; Bayry et al., 2004; Scott-Taylor et al., 2004; Viallard et al., 2005; Bayry, 2005).

Outro ponto que deve ser levado em consideração em relação a possíveis defeitos na apresentação e coestimulação dos LB, justificando a baixa diferenciação para células de memória e plasmoblastos observada após a vacinação contra Influenza, esta relacionado aos receptores do tipo Toll. Sabe-se que durante a resposta contra o vírus Influenza a liberação dos sinais promovidos pelos receptores do tipo Toll-7, Toll-9 e Toll-3 estão relacionados a produção e liberação de citocinas pró inflamatórias, além de IFNs do tipo

${ }^{15}$ PBL: Plasmoblastos. 
1 (Lund et al., 2004). Recentemente, em 2012, Sanches-Ramón et al. observaram que os LB de 35 pacientes com ICV após serem ativados via os receptores do tipo Toll-7 e Toll-9 apresentaram menor proliferação e produção de citocinas, além de baixa produção de IgG e IgA. Taraldsrud et al., (2013) avaliando a expressão dos receptores do tipo Toll em células dendríticas de 26 pacientes com ICV, também verificou a presença de defeitos na sinalização destes dois receptores.

Em relação ao aumento na frequência de $\mathrm{SMB}^{16}$ e plasmoblastos terem ocorrido logo após 1 mês da vacinação, não podemos afirmar que a resposta antígeno-específica dos pacientes foi tardia, muito pelo contrário, ela se mostrou precoce, porém não foi duradoura, uma vez que tanto as populações de memória quanto plasmoblastos declinaram no terceiro mês após a vacinação.

Bertram et al., 2002, observou que em camundongos, durante a resposta imune contra o vírus Influenza, a molécula ICOS atua principalmente na produção de IFN- $\gamma$ pelos $\mathrm{LT} \mathrm{CD}^{+}$e o seu bloqueio resulta em menor ativação de $\mathrm{LT} \mathrm{CD}^{+}, \mathrm{CD} 8^{+}$, além de diminuição da produção de IgG específico pelos LB. Assim, o defeito em ICOS, já observado em alguns pacientes com ICV pode ser uma justificativa para explicar a baixa expressão das populações de $\mathrm{SMB}$ e $\mathrm{PBL}^{17}$, uma vez que esta molécula está associada com a diferenciação dos LB naive para células B de memória e plasmoblastos (Grimbacher et al., 2003).

Também nos questionamos sobre um possível estado de exaustão celular que tanto os linfócitos B de memória quanto os plasmoblastos dos pacientes com ICV possam apresentar, por conta da constante tentativa de produção de anticorpos.

A exaustão celular é caracterizada pela progressiva perda da função, devido a um estado de hiperativação, resultando na deleção celular (Akbar et al., 2011). Em pacientes HIV positivos já foi observado que devido a persistente replicação viral, os LB expressam uma maior quantidade de marcadores de ativação e proliferação e por conta deste estado de hiperativação, eles passam a apresentar defeitos em diversos componentes coestimulatórios, assim como também na geração de uma adequada resposta humoral a diversos estímulos. Nestes pacientes, a frequência de células B de memória se encontra muito reduzidas e a subpopulação de LB naive apresenta elevada

\footnotetext{
${ }^{16}$ SMB: Linfócito B de Memória com Troca de Isotipo.

${ }^{17}$ PBL: Plasmoblastos.
} 
expressão, assim como observado em pacientes com ICV, entretanto, estas células se encontram em elevado estágio de exaustão celular (Fogli et al., 2011).

Saxon et al., (1995) descreveram que as células B de pacientes com ICV apresentam uma maior expressão da molécula CD95 (Apo-1/FAS), que está associada ao desenvolvimento de apoptose e em 2013, Clemente et al., verificaram que os LB de memória de 22 pacientes com ICV eram mais sensíveis ao desenvolvimento de apoptose espontânea após a estimulação in vitro com anti-CD40, indicando que o aumento da apoptose durante o desenvolvimento de uma resposta imunológica pode resultar em menor produção de anticorpos específicos. Assim, a queda na frequência de SMB e PBL poderia ser devida a um possível estado de exaustão celular que culminaria em apoptose logo após a sua ativação, o que também explicaria a baixa produção de anticorpos específicos após a vacinação.

Possivelmente por conta da deficiente diferenciação e ativação das populações de SMB e PBL, a subpopulação de $\mathrm{MZB}^{18}$ poderia estar atuando diretamente na tentativa de responder contra o vírus Influenza, podendo assim, justificar sua maior expressão no período pós 3 meses.

Pacientes com ICV, geralmente apresentam redução da subpopulação de MZB, porém alguns podem apresentar um aumento em sua expressão (Sánchez-Ramón et al.,2008). Pedreschi et al., (2011) estudando os pacientes deste trabalho, os quais estavam inseridos em um grupo de 70 pacientes, verificou não haver diferença na frequência de MZB entre pacientes e controles, sendo este resultado também observado por Mouilot et al. (2010).

O papel que os linfócitos $\mathrm{B}$ de zona marginal apresentam na resposta contra antígenos polissacarídeos já está muito bem documentado, porém estas células apresentam um vasto repertório que não é somente dirigido as respostas $T$ independentes. Estudos in vitro e in vivo têm demonstrado que durante a resposta imune $\mathrm{T}$ dependente, estas células são capazes de capturar, processar e apresentar antígenos aos LT, além de expressar moléculas coestimulatórias de forma mais rápida e eficiente que os LB foliculares. Além disso, também foi observado que estas células apresentam capacidade de se diferenciar rapidamente para plasmoblastos (Oliver et al., 1999; Martin e Kearney, 2002).

\footnotetext{
${ }^{18}$ MZB: Linfócito B de Zona Marginal.
} 
Capolunghi et al., (2008) também descreveram que linfócitos B de zona marginal de pacientes com ICV podem estar realizando a ponte entre a resposta inata e adaptativa, assim podemos sugerir que o aumento de expressão de MZB verificado possa indicar que em uma tentativa de prolongar a resposta humoral para vacina de Influenza, elas tenham proliferado para que pudessem se diferenciar para plasmoblastos. Outra hipótese é que elas poderiam estar atuando como células apresentadoras de antígenos para os LT, uma vez que a via de apresentação envolvendo células dendríticas podem estar defeituosas.

Os linfócitos B podem desempenhar diversas funções durante a resposta contra Influenza, sua principal função está relacionada à produção de anticorpos específicos capazes de levar a neutralização do vírus e consequentemente à citotoxicidade celular dependente de anticorpos, mas os LB também podem atuar através da secreção de citocinas do perfil Th1 como IL-12 e IFN- $\gamma$, que levariam a ativação tanto de LT CD4 ${ }^{+}$ para o perfil Th1 quanto LT citotóxicos e células NK, além da ativação da cascata de sistema complemento (Gerhard, 2001; Harris et al., 2000).

O aumento de MZB verificado nos pacientes após a vacinação também pode nos indicar que esta subpopulação esteja tentando manter a resposta contra o vírus através da produção de citocinas que levem a ativação de linfócitos $\mathrm{T}$ e de vários componentes da resposta inata.

Nossos resultados demonstraram que os pacientes com ICV foram capazes de responder às vacinas de Influenza e $S$. pneumoniae, uma vez que apresentaram considerável melhora clínica após a vacinação. Apesar da baixa produção de anticorpos específicos, característica da doença, devido aos vários defeitos descritos nos LB, pudemos observar que as subpopulações de LB estudadas se mostraram capazes de realizar o reconhecimento do vírus Influenza e que provavelmente em conjunto com a ativação de outros componentes do sistema imunológico, os linfócitos B de zona marginal possam estar atuando na tentativa de prolongar a resposta imune após a vacinação.

A eficácia de uma vacina é mensurada pela indução de proteção contra a infecção por meio da estimulação e desenvolvimento de células efetoras de vida longa e células de memória (Abbas, 2008).

Em 2007, Goldacker et al. analisaram a produção de anticorpos específicos e a frequência de LB de memória após a administração das vacinas contra Tétano, Difteria, 
H. influenzae, hepatites A e B e $S$. pneumoniae em 21 pacientes com ICV e identificaram que alguns pacientes foram capazes de responder às vacinas, sugerindo que a classificação dos pacientes em respondedores e não respondedores pode auxiliar no acompanhamento da doença.

Entre as subpopulações LB estudadas neste trabalho, os plasmoblastos representam o último estágio da diferenciação dos LB antes da diferenciação para plasmócitos, a célula B efetora, que ocorre na medula óssea. Por conta disto, nos questionamos se haveria correlação entre esta subpopulação e a população de SMB, principal célula de memória secretora de anticorpos específicos.

Após observarmos que os pacientes apresentaram a maior expressão de SMB e PBL logo ao primeiro mês da administração das vacinas, verificamos haver uma correlação entre o aumento destes 2 subtipos de LB após a vacinação. Esta correlação nos auxiliou na subdivisão dos pacientes de acordo com o padrão de resposta após a vacinação, a saber: pacientes com o aumento da expressão de SMB e PBL (G1), aumento apenas das células B de memória (G2) ou apenas a produção de células B efetoras (G3).

Observamos que dos pacientes estudados, a maioria esteve classificado no G1, seguidos pelos pacientes que apresentaram aumento na expressão apenas de SMB (G2), indicando que mesmo que abaixo do observado nos controles, após a vacinação, estes pacientes foram capazes de aumentar a expressão destas duas subpopulações.

Em relação a avaliação clínica, os pacientes classificados nos grupos G1 e G2 apresentaram uma menor pontuação do score de sintomas, indicando que os pacientes que foram capazes de aumentar a expressão de SMB após a vacinação apresentaram uma maior melhora clínica que os pacientes que não foram capazes de produzir SMB após a administração das vacinas.

Em relação a produção de anticorpos específicos pelos dois grupos de estudo, nos limitamos a analisar apenas os níveis séricos de anticorpos específicos para H1N1, uma vez que a sorologia para Influenza demonstrou a presença de anticorpos específicos para os sorotipos A e B na alíquota de imunoglobulina que os pacientes receberam durante o período estudado. Observamos que dos pacientes classificados nos grupos G1 e G2, alguns foram capazes de desenvolver soroproteção e soroconversão para H1N1, reforçando o resultado de que os pacientes que foram capazes de apresentar um aumento na expressão de SMB após a vacinação permaneceram protegidos por um período de tempo maior e por conta disso 
apresentaram uma melhora clínica mais evidente do que os pacientes que não conseguiram desenvolver a expressão deste subtipo de LB após a vacinação.

Ressaltamos a necessidade de que mais pacientes sejam avaliados e classificados, para reforçar as observações deste trabalho. Também consideramos que outros parâmetros imunológicos devam ser contemplados nesta subdivisão, principalmente em relação às subpopulações de memória de $\mathrm{LT} \mathrm{CD}^{+}$e $\mathrm{LT} \mathrm{CD}^{+}$, que podem nos auxiliar no entendimento de quais mecanismos possam estar envolvidos na melhora clínica que os pacientes apresentam após a vacinação.

Em resumo, observamos uma melhora clínica à vacinação de pacientes com ICV para Influenza, H1N1 e $S$. pneumoniae que foi acompanhada de uma resposta disfuncional observada nos subtipos de linfócitos B. Esta observação reforça a provável incapacidade de maturação dos linfócitos B em células de memória e plasmócitos nestes pacientes, justificando a incapacidade de produção de anticorpos específicos. Ainda assim, as respostas foram diversas no grupo de pacientes, comprovando a heterogeneidade da doença e justificando a necessidade de uma divisão dos pacientes conforme o tipo de resposta apresentada. 
1. Apesar da melhora clínica, os pacientes não foram capazes de produzir anticorpos específicos para Influenza, H1N1 e S. pneumoniae.

2. A resposta dos linfócitos $B$ contra o vírus Influenza não foi duradoura nos pacientes, pois apesar da expressão de linfócito B de memória com troca de isotipo ter sido semelhante aos controles, a expressão de plasmoblastos foi discreta e precoce, ocorrendo por volta de 1 mês após a vacinação e ambas as subpopulações decaíram logo em seguida.

3. O aumento na expressão de linfócito B de zona marginal que ocorreu ao terceiro mês após a vacinação, deve ser melhor estudado, pois pode sugerir a atuação desta subpopulação como célula apresentadora de antígeno para linfócitos T.

4. A classificação dos pacientes de acordo com o tipo de resposta após a vacinação, indicou que os pacientes que foram capazes de aumentar a expressão de células B de memória (G1 e G2) soroconverteram e desenvolveram soroproteção para H1N1, resultando em uma maior redução na pontuação do score de sintomas, quando comparados aos pacientes que apresentaram apenas aumento na expressão de plasmoblastos. 
1) ABBAS, A.K; LICHTMAN, A.H; POBER, J.S. Desenvolvimento dos Linfócitos e o Rearranjo e a Expressão dos Genes dos Receptores de Antígenos. In: Imunologia Celular e Molecular. São Paulo: Saunders Elsevier, 2008. p 153- 186.

2) ABBAS, A.K; LICHTMAN, A.H; POBER, J.S. Imunodeficiências Congênitas e Adquiridas. In: Imunologia Celular e Molecular. São Paulo: Saunders Elsevier, 2008. p.463-487.

3) ABBAS, A.K; LICHTMAN, A.H; POBER, J.S. Imunidade aos Microrganismos. In: Imunologia Celular e Molecular. São Paulo: Saunders Elsevier, 2008. p.370-372.

4) ABOLHASSANI, $\mathrm{H} ; \quad$ FARROKHI, A.S; POURHAMDI, S; MOHSMMADINEJAD, P; SAGHI, B; MOAZZENI, S.M. Expression of ActivationInduced Cytidine Deaminase Gene in B Lymphocytes of Patients with Common Variable Immunodeficiency. Iran J. Pediatr. 23: 451-457; 2013.

5) ABOLHASSANI, H; SAGVAND, B.T; SHOKUHFAR, T; MIRMINACHI, B; REZAEI, N; AGHAMOHAMMADI, A. A Review on Guidelines for Management and Treatment of Common Variable Immunodeficiency. Expert Rev. Clin. Immunol. 9(6): 561-575; 2013.

6) AGEMATSU, K; HOKIBARA, S; NAGUMO, H; KOMIYAMA, A. CD27: A Memory B Cell Marker. J Clin Immunol. 21:204-206, 2000.

7) AGENES, F; ROSADO, M.M; FREITAS, AA. Peripheral B cell Survival. Cell Mol Life Sci. 57: 1220-1228, 2000.

8) AGONDI, R.C; BARROS, M.T; KOKRON, C.M; COHON, A; OLIVEIRA, A.K.B; KALIL, J, et al. Can Patients with Common Variable Immunodeficiency Have Allergic Rhinitis?. Am. J. Rhinol \& Allerg.27(2): 79-84, 2013.

9) AHN, S; CUNNINGHAM-RUNDELS, C. Role of B Cell in Common Variable Immune Deficiency. J. Clin Immunol. 5(5): 557-564, 2009.

10) AKBAR, A.N; HENSON, S.M. Are Senescence and Exhaustion Intertwined or Unrelated Processes that Compromise Immunity?. Nature Rev. 11:289-295, 2011.

11) AL HERZ, W; BOUSFIHA, A; CASANOVA, J.L; CHATILA, T; CONLEY, M.E; CUNNINGHAM-RUNDLES, C, et al. Primary Immunodeficiency Diseases: An Update on the Classification From the International Union of Immunological Societies Expert Committee for Primary Immunodeficiency. Front Immunol. 22(5): 162, 2014. 
12) ALACHKAR, H; TAUBENHEIM, N; HAENEY, M.R; DURANDY, A; ARKWRIGHT, P.D. Memory Switched B Cell Percentage And Not Serum Immunoglobulin Concentration is Associated With Clinical Complications in Children And Adults With Specific Antibody Deficiency And Common Variable Immunodeficiency. J Clin Immunol. 120: 310-318, 2006.

13) AMATO NETO, V. Erradicação de Doenças por Meio de Vacinações . In: Imunizações: Atualizações, Orientações e Sugestões. São Paulo: SBiM, 2011. p96.

14) AMATO NETO, V. Influenza. In: Imunizações: Atualizações, Orientações e Sugestões. São Paulo: SBiM, 2011. P298-309.

15) ARRUDA, E; HAYDEN, F.G. Influenza Virus, Respiratory Syncytial, Parainfluenza Viruses, Rhinovirus and Respiratory Adenoviruses. In: Tropical infections disease - principles, pathogens \& practice. Philadelphia: Churchill Livingstone, 1999. p. 1109-1121.

16) AUKRUST, P.F; LIEN, E; KRISTOFFERSEN, A.K; MULLER, F; HAUG, C.J; ESPEVIK, T. Persistent Activation of the Tumor Necrosis Factor System in a Subgroup of Patients with Common Variable Immunodeficiency - Possible Immunologic and Clinical Consequences. Blood. 87: 674 -681, 1996.

17) AUKRUST, P.F; MULLER, S.S. Elevated Serum Levels on Interleukin - 4 and Interleukin - 6 in Patients with Common Variable Immunodeficiency (CVID) are associated With Chronic Immune Activation and Low Numbers of CD4 ${ }^{+}$Lymphocytes. Clin Immunol Immunopathol. 70:217-224, 1994.

18) BALDY, J.L.S. Estreptococcias.. In: Tratado de Infectologia. São Paulo: Atheneu, 2005.

19) BANCHEREAU, J; STEINMAN, R.M. Dendritic Cells and Control of Immunity. Nature. 392: 245-252, 1998.

20) BARBOSA, R.R; SILVA, S.P; SILVA, S.L; MELO, A.C; PEDRO, E; BARBOSA, M.P, et al. Primary B Cell Deficiencies Reveal a Link Between Human IL17 Producing CD4 T Cell Homeostasis and B cell Differentiation. PlosONe. 6(8): 1-9, 2011. 
21) BAYRY, J; HERMINE, O; WEBSTER, D.A; LEVY, Y; KAVERI, S.V. Common Variable Immunodeficiency: The Immune System in Chaos. Trends in Molec Medicine. 11(8): 370-376, 2005.

22) BAYRY, J; LACROIX-DESMAZES, S; KAZATCHKINE, M.D; GALICIER, L; LEBOTÃO CELULARIER, Y; WEBSTER, D, et al. Common Variable Immunodeficiency is Associated with Defective Functions of Dendritic Cells. Blood. 104(8): 2441-2443, 2004.

23) BEREZIN, E.N; CARDENUTO, M. D; FERREIRA, L.L; OTSUKA, M; GUERRA, M.L; BRANDILEONE, M.C. Distribution of Streptococcus pneumoniae Serotypes in Nasopharyngeal Carriage and in Invasive Pneumococcal Disease in São Paulo, Brazil. Peadiatr. Infect. Dis. 26(7): 643-645, 2007.

24) BERGEN, R; BLACK, S; SHINEFIELD, H; LEWIS, E; RAY, P; HANSEN, J, et al. Safety and Coldy-Adapted Live Attenuated Influenza Vaccine in a Large Cohort of Children and Adolescents. Pedriatr Infect Dis. J. 23(2): 138-144, 2004.

25) BERGER, M. Principles and Advances in Immunoglobulin Replacement Therapy for Primary Immunodeficiency. Immunol Allergy Clin North Am. 28:413437, 2008.

26) BERTRAM, E.M; TAFURI, A; SHAHINIAN, A; CHAN, V.S; HUNZIKER, L; OHASHI, P.S, et al. Role of Icos Versus CD28 In Antiviral Immunity. Eur. J. Immunol. 32(12): 3376-3385, 2002.

27) BOGAERT, D; GROOT, R; HERMANS, P.W. Streptococcus pneuminae Colonisation: The Key to Pneumococcal Disease. Lancet Infect. Dis. 4: 144-154, 2004. 28) BONILLA, F.A; BERNSTEIN, I.L; KHAN, D.A; BALLAS, Z.K; CHINEN, J; FRANK, M.M, et al. Practice Parameter for the Diagnosis and Management of Primary Immunodeficiency. Ann Allergy Asthma Immunol. 94(5):63, 2005.

29) BONILLA, F.A; GEHA, R. S. Common Variable Immunodeficiency. Pediatr. Res. 65(5): 13-19, 2009.

30) BONILLA, F.A; GEHA, R.S. Primary Immunodeficiency Diseases. J Allergy Clin Immunol. 111:571-581, 2003.

31) Brasil. Ministério da Saúde. Secretaria de Vigilância em Saúde. Departamento de Vigilância Epidemiológica. Guia de Vigilância Epidemiológica. 7 Ed. Brasilia (DF); 2009b. 
32) BUSSE, P.J; RAZVI, S.F, CUNNINGHAM-RUNDLES, C. Efficacy of Intravenous Immunoglobulin in the Prevention of Pneumonia in Patients With Common Variable Immunodeficiency. J Allergy ClinImmunol. 109(6):101-104, 2002.

33) CAMBRONERO, R; SEWELL, W.A; NORTH, M.E, WEBTER, A.D; FARRANT, J. Up-Regulation of IL-12 In Monocytes: A Funcdamental Defect in Common Variable Immunodeficiency. J. Immunol. 164 (1): 488-494, 2000.

34) CAPOLUNGHI, F; CASCIOLI, S; GIORDA, E; ROSADO, MM; PLEBANI, A; AURITI, C, et al. CpG Drives Human Transitional B Cells to Terminal Differentiation and Production of Natural Antibodies. J. Immunol. 180: 800-808, 2008.

35) CARBONE, J; SARMIENTO, E; RODRIGUEZ-MOLINA, J.J; FERNANDEZCRUZ, E. Atypical Presentation of Common Variable Immunodeficiency Without Infections. J Allergol Immunopathol. 32:218-222, 2004.

36) CARDOSO, M. R.A; NASCIMENTO-CARVALHO, C.M; FERRERO, F; BEREZIN, E.N; RUVINSKY, R; CAMARGOS, A.M, et al. Penicillin-Resistant Pneumococcus and Risk of Treatment Failure in Pneumonia. Arch. Dis. Child. 93: 221$225,2008$.

37) CARNEIRO-SAMPAIO, M; MORAES-VASCONCELOS, D; KOKRON, C.M; JACOB, C.M.A; TOLEDO-BARROS, M; DORNA, M.B, et al. Primary Immunodeficiency Diseases in Different Age Groups: A Report on 1,008 Cases from a Single Brazilian Reference Center. J. Clin. Immunol. 33:716-724, 2013.

38) CARSETTI, R; ROSADO, M.M; WARDEMANN, H. Peripheral Development of B Cells in Mouse and Man. Immunol Rev. 197:179-191, 2004.

39) CARVALHO, K.I; MELO, K.M; BRUNO, F.R; SNYDER-CAPPIONE, J.E; NIXON, D.F; COSTA-CARVALHO, B.T, et al. Skewed Distribution of Circulating Activated Natural Killer T (NKT) Cells in Patients With Common Variable Immunodeficiency Disorders (CVID). PlosOne. 9(5): e12652, 2010. 
40) CASTIGLI, E; WILSON, S.A; ELKHAL, A; OZCAN, E; GARIBYAN, L; GEHA, R.S. Transmembrane Activator and Calcium Modulator And Cyclophilin Ligand Interactor Enhances CD40-Driven Plasma Cell Differentiation. J. Allergy Clin Immunol. 120(4): 885-891, 2007.

41) CAVALIERE, F.M; MILITO, C; MARTINI, H; SCHLESIER, M; DR $\square$ GUER, R; SHÜTZ, K, et al. Quantification of IgM and IgA Anti- Pneumococcal Capsular Polysaccharides by a New ELISA Assay: A Valuable Diagnostic and Prognostic Tool for Common Variable Immunodeficiency. J Clin Immunol. 33:838-846, 2013.

42) Centers of Disease Control and Prevention. CDC (2010). Outbreak of SwineOrigin Influenza A (H1N1) Virus Infection in Mexico. Disponível em: http://wwwcdc.gov/mmwR/preview/mmwrhtml/mm58d0430a2.htm

43) CHAPEL, H; CUNINGHAM-RUNDLES, C. Update in Understanding Common Variable Immunodeficiency Disorders (CVIDS) and the Management of Patients with These Conditions. Br J Haematol. 45(6): 709-727, 2009.

44) CHAPEL, H; LUCAS, M; LEE, M; BJORKANDER, J; WEBSTER, D;GRIMBACHER, B, et al. Common Variable Immunodeficiency Disorders: Division Into Distinct Clinical Phenotypes. Blood. 112(2): 277-286, 2008.

45) CHEN, K; COONROD, E.M; KUMANOVICS, A; FRANKS, Z.F; DURTSCHI, J.D; MARGRAF, R.L, et al. Germline Mutations in NFKB2 Implicate the Noncanonical NF-Kappa B Pathway in Pathogenesis of Common Variable Immunodeficiency. Am. J. Hum. Genet. 93: 812-824, 2013.

46) CHOVANCOVA, Z; VLKOVA, M; LITZMAN, J; LOKAJ, J; THON, V. Antibody forming Cells and Plasmablasts in Peripheral Blood in CVID Patients After Vaccination. Vaccine. 29: 4142-4150, 2011.

47) CINTRA, O.A.L; REY, L.C. Safety, Immunogenicity and Efficacy of Influenza Vaccine in Children. J. Pedriatr. 82(3): 83-90, 2006.

48) CLEMENTE, A; PONS, J; LANIO, N; MATAMOROS, N; FERRER, J.M. $\mathrm{CD} 27^{+}$B Cells from a Subgroup of Common Variable Immunodeficiency Patients Are Less Sensitive to Apoptosis Rescue Regardless of Interleukin-21 Signaling. Clin. Exp. Immunol. 174: 97-108, 2013.

49) CONLEY M.E; NOTARANGELO L.D; ETZONI A. Diagnostic Criteria for the Primary Immunodeficiencies. Representing PAGID (Pan-American Group for Immunodeficiency) and ESID (European Society for Immunodeficiencies). Clin Immunol. 93(3): 190-197, 1999. 
50) COSTA-CARVALHO, B.T; COCCO, R.R; RODRIGUES, W.M; COLLA, V.A; SOLÉ, D; CARNEIRO-SAMPAIO, M.M. Pneumonias de Repetição em Pacientes com Deficiência de Anticorpos e Imunoglobulinas Normais. J. Pneumol. 28(3):155 -158, 2002.

51) COUCEIRO, J.N.SS. Viroses Respiratórias. In: Introdução à Virologia Humana. Rio de Janeiro: Guanabara Koogan, 2002. p119-125.

52) COX, N.J; SUBBARAO, K. Influenza. Lancet. 354: 1277-1282, 1999.

53) CRUM-CIANFLONE, N.F; EBERLY, L.E; DUPLESSIS, C; MAGUIRE, J; GANESAN, A; FAIX, D, et al.. Immunogenicity of a Monovalent 2009 Influenza A (H1N1) Vaccine in an Immunocompromised Population: A Prospective Study Comparing HIV- Infected Adults and HIV- Unfinfected Adults. Clin Infect Dis. 52:138-146, 2011.

54) CUNNINGHAM-RUNDLES, C. How I Treat Common Variable Immune Deficiency. Blood. 116:7-15, 2010.

55) CUNNINGHAM-RUNDLES C. Human B Cell Defects in Perspective. Immunol Res. 54: 227-232, 2012.

56) CUNNINGHAM-RUNDLES C.; ALTSCHUL A. Chronic Urticaria Angioedema as the First Presentations of Common Variable Immunodeficiency. J Allergy Clin Immunol. 110: 664-5, 2002.

57) CUNNINGHAM-RUNDLES C; BODIAN C. Common Variable Immunodeficiency: Clinical and Immunological Features of 248 Patients. J Clin Immunol. 92:34-48, 1999.

58) CUNNINGHAM-RUNDLES, C; RADIGAN, L; KNIGHT, A.K; ZHANG, L; BAUER, L; NAKAZAWA, A. TLR9 Activation is Defective in Common Variable Immune Deficiency. J Immunol. 176:1978-1987, 2006.

59) CUGINI, D.M; SILVA, F.P.A; ÉTORRI, H; KUMENAUER, M.Z; MOREIRA, M.E; PAULUCCI, R.S. Perfil Epidemiológico dos Casos de Influenza A H1N1 em Taubaté - SP. Boletim Epidemiológico de São Paulo. BEPA. 7(81), 2010.

60) DAGAN, R; LIPSITCH, M. Changing the Ecology of Pneumococci With Antibiotics and Vaccines. In: The Pneumococcus. Washington: ASM Press, 2004. p.283-313. 
61) DE LAVALLADE, H; GARLAND, P; SEKINE, T, et al. Repeated Vaccination is Required to Optimize Seroprotection Against H1N1 in the Immunocompromissed Host. Haematol. 96:307-314, 2011.

62) DESJARDINS, M; MAZER, B.D. B-Cell Memory and Primary Immune Deficiencies: Interleukin -21 Related Defects. Curr Opin Allergy Clin Immunol. 13:639-645, 2013.

63) DE SCHUTTER, I; MALFROOT, A; PIÉRARD, D; LAUWERS, S. Pneumococcal Serogroups and Serotypes in Severe Pneumococcal Pneumonia in Belgian Children: Theoretical Coverage of 7-Valent and 9-Valent Pneumococcal Conjugate Vaccines. Pediatr. Pulmonol. 41(8): 765-770, 2006.

64) DOWNSON, C. What is a Pneumococcus? In: The pneumococcus. Washington: ASM Press. 2004. p. 30-48

65) DURANDO, P; FENOGLIO, D; BOSCHINI, A; ANSALDI, F; ICARDI, G; STICCHI, L, et al. Safety and Immunogenicity of Two Influenza Virus Subunit Vaccines, With or Without MF59 Adjuvant, Administered to Human Immunodeficiency Virus Type-1-Seropositive and Seronegative Adults. Clinn Vaccine Immunol. 15: 253$259,2008$.

66) EADES-PERNER, A.M;GATHMANN, B;KNERR, V;GUZMAN, D;VEIT, D;KINDLE, G;GRIMBACHER, B.ESID Registry Working Party. The European Internet-Based Patient and Research Database For Primary Immunodeficiencies: Results 2004-06. Clin Exp Immunol.147(2):306-12, 2007

67) EIJKHOUT, H.W; VAN DER MEER, J.W.M; KALLENBERG, G.G;WEENING, R.S; VAN DISSEL, J.T; SANDERS, L.A.M, et al. The Effect of Two Different Dosages of Intravenous Immunoglobulin on the Incidence of Recurrent Infections In Patients With Primary Hypogammaglobulinemia. A Randomized, DoubleBlind, Multicenter Crossover Trial. Ann Intern Med. 135: 165-174, 2001.

68) EMA/CPMB. Note for Guidance on Harmonisation of Requirements for Influenza Vaccines. London: European Medicines Agency/Committee for Proprietary Medicinal Products, 1996.

69) ESOLEN L.M, FASANO M.B, FLYNN J, BURTON A, LEDERMAN H.M. Pneumocystis carini Ostemyelitis in a Patient With Common Variable Immunodeficiency. N Engl J Med. 326: 999-1001, 1992. 
70) FARIA, A.M.D. Avaliação da Resposta Humoral á Vacina Pneumocócica Conjugada 7- Valente em Crianças com Asma Moderada em Uso de Corticóide Inalatório e em crianças com Fibrose Cística. Dissertação de Mestrado. São Paulo (SP): Faculdade de Medicina da Universidade de São Paulo, 2009.

71) FARRANT, J; BRYANT, A.E; ALMADOZ, F; SPICKETT, G;EVANS, S.W; WEBSTER, A.D.B.B. Cell Function in Aquired Common Variable Hypogamaglobulinemia: Proliferative Responses to Lymphokines. J. Clinn.Immunol. Immunopathol. 51: 196-204, 1989.

72) FARRANT, J; BRYANT, A.E; LEVER, A.A; EDWARDS, A.J; KNIGHT, S.C; WEBSTER, A.D. Defective Low Density Cells of Dendritic Morphology From the Blood of Patients With Common Variable Hypogammaglobulinaemia: Low Immunoglobulin Production on Stimulation of Normal B Cell.Clin. Exp Immunol.61: 189-194, 1985.

73) FERREIRA, A.W; MORAES, S.L. Estreptococcias. In: Diagnóstico Laboratorial das Principais Doenças Infecciosas e Autoimunes. Rio de janeiro: Guanabara Koogan, 2013. 183-190.

74) FEVANG B, YNDESTAD A, SANDBERG WJ, HOLM AM, MULLER F, AUKRUST P, FROLAND SS. Low Numbers of Regulatory T Cells in CVID: Association With Chronic Inflammation in vivo. Clin Exp Immunol. 147:521-5, 2007.

75) FINCK, A; VAN DER MEER, J.W; SCHAFFER, A.A; PFANNSTIEL, J; FIESCHI, C; PLEBANI, A, et al. Linkage of Autosomal-Dominant Common Variable Immundeficiency to Chromosome 4q. Eur. J Hum Genet. 14:867-875, 2006.

76) FOGLI, M; TORTI, C; MALACARNE, F; FIORENTINI, S; ALBANI, M; IZZO, I, et al. Emergence of Exhausted B Cells in Asymptomatic HIV-1 Infected Naive for HAART is Related to Reduced Immune Surveillance. Clin. Developmental Immunol. 2012: 1-10, 2011.

77) FOSTER, D.A; TALSMA, A; FURUMOTO-DASON, A; OHMIT, S.E; MARGULIES, J.R; ARDEN, N.A, et al. Influenza Vaccine Effectiveness In Preventing Hospitalizations for Pneumonia in Elderly. J Epidemiol. 136: 296-307, 1992.

78) FULCHER, D.A; AVERY, D.T; FEWINGS, N.L; BERGLUND, L.J; WONG, $\mathrm{S}$, et al. Invariant Natural Killer (iNKT) $\mathrm{T}$ cell deficiency in patients with Common Variable Immunodeficiency. Clin Exp Immunol. 157:365-369, 2009. 
79) GATHMANN, B; MAHLAOUI, N; GÉRARD, L;OKSENHENDLER, E; WARNATZ, K; SCHULZE, I, et al. Clinical Picture And Treatment of 2212 Patients With Common Variable Immunodeficiency. J. Allerg. Clin. Immunol. 134(1): 116126, 2014.

80) GENRE, J; ERRANTE, R.P; KOKRON, C.M; TOLEDO, M.B; CAMARA, N.O.S; RIZZO, L. Reduced Frequency of $\mathrm{CD}^{+} \mathrm{CD} 25^{\mathrm{HIGH}} \mathrm{FOXP}^{+}$Cells and Diminished FOXP3 Expression at the Single-Cell Level in Patients with Common Variable Immunodeficiency: A link to Autoimmunity?. Clin Immunol. 132: 215-221, 2009.

81) GERHARD, W. The Role of The Antibody Response in Influenza Virus Infection. Curr.Top Microbiol Immunol. 260: 171-190, 2001.

82) GIOVANNETTI, A; PIEDOMINIRCI, M; MAZETTA, F; MARZIALI, M; RENZI, C, et al. Unravelling the Complexity of $\mathrm{T}$ cell Abnormalities in Common Variable Immunodeficiency. J. Immunol. 178: 3932-3943, 2007.

83) GIRARD, M.P; CHERIAN, T; PERVIKOV, Y; KIENY, M.P. A Review of Vaccine Research and Development: Human Acute Respiratory Infections. Vaccine. 23(50): 5708-5724, 2005.

84) GOLDACKER, S; DRAEGER, R; WARNATZ, K; HUZLY, D; SALZER, U; THIEL, J, et al. Active Vaccination in Patients with CVID. J Clin Immunol. 124: 294-303, 2007.

85) GOOD-JACOBSON, K.L; TARLINTON, D.M. Multiple Routes to B cell Memory. International Immunol. 24 (7): 403-408, 2012.

86) GORCZYNSKI, R: Imunologia Clínica. Rio de Janeiro. Reichman e Afonso, 2001.

87) GORSE, G.L; OTTO, E.E; DAUGHADAY, C.C; NEWMAN, F.K; EICKHOFF, C.S; POWERS, D.C, et al. Influenza Virus of Patients With Chronic Lung Disease. Chest. 112: 1221-1233, 1997.

88) GRAHAM, M.B; BRACIALE, T.J. Resistence And Recovery From Lethal Influenza Virus Infection In B Lymphocyte Deficient Mice. J. Exp. Med. 186:20632068, 1997

89) GRIMBACHER, B; WARNATZ, K; PETER, H.H. The Immunological Synapse for B Cell Memory: The Role of the ICOS And its Ligand for the Longevity of Humoral Immunity. Curr Opin Allergy Clin Immunol. 3(6): 409-419, 2003. 
90) HARRIS, D.P; HAYNES, L; SAYLES, P.C, et al. Reciprocal Regulation of Polarized Cytokine Production by Effector B and T cells. Nature Immunol.1: 475, 2000.

91) HAUSSER, C; VIRELIZIER, J.L; BURIOT, D; GRISCELli C. Common Variable Hypogammaglobulinemia in Children. Clinical and Immunologic Observations in 30 patients. Am J Dis Child. 137:833-837, 1983.

92) HAYMORE, B.R; MIKITA, C.P; TSOKOS, G.C. Memory B Cells in Common Variable Immune Deficiency Presenting as Autoimmune Disease. Autoimmunity Rev. 7(4): 309-312, 2007.

93) HYAMS, C; CAMBERLEIN, E; BROWN, J.S. The Streptococcus pneumoniae Capsule Inhibits Complement Activity and Neutrophil Phagocytosis by Multiple Mechanisms. Infect Immun. 78(2): 704-715, 2010.

94) HONG, R; AGRAWAL, S; GOLLAPUDI, S; GUPTA, S. Impaired Pneumovax23 - Induced Monocyte Derived Cytokine Production in Patients with Common Variable Immunodeficiency. J Clin Immunol. 30: 435-441, 2010.

95) HORN, J; MANGUIAT, A; BERGLUND, L.J; KNERR, V; TAHAMI, F; GRIMBACHER, B, et al. Decrease in Phenotypic Regulatory T Cells in Subsets of Patients with CVID. J Clin Exp Immunol. 156: 446-454, 2009.

96) HUCKIED, A; BUNGENER, L; STEGMANN, T; DAEMEN, T; MEDEMA, J; PALACHE, A.M, et al. The Virosome Concept for Influenza Vaccines. Vaccine. 23(1): 26-38, 2005.

97) JEGO, G; PALUCKA, A.K; BLANCK, J.P; CHALOUNI, C; PASCUAL, V; BANCHEREAU, J. Plasmacytoid Dendritic Cells Induce Plasma Cell Differentiation Through Type Interferon and Interleukin 6. Immunity. 19:225-234, 2003.

98) JOFRE, M; PERRET, L.P; DABANCH, P; JEANNETTE, A.V; OLIVARES, C; AGUILERA, S, et al. Influenza: The Reemergence of An Ancient Disease And Its Risk of Pandemia. Rev chil. Infectol. 22(1): 75-88, 2005.

99) JOLLES, S. The Variable in Common Variable Immunodeficiency: A Disease of Complex Phenotypes. J Allerg. Clin. Immunol Pract. 1(6), 545-5562013.

100) JUNKER AK, BONILLA FA, SULLIVAN KE. How to flee the flu.ClinImmunol. 2004;112(3):219-20.

101) KEESTRA, R.W. House Calls to Patients With an Immunodeficiency Disorder. Tijdschr Kindergeneeskd. 56(5): 218-225, 1988. 
102) KELlY, D; POLlARD, A.J; MOXON, E.R. Immunological Memory - The Role of B cells in Long-Term Protectior Against Invasive Bacterial Pathogens. JAMA. 294(23): 3019-3023, 2005.

103) KIM, J.O; WEISER, J.N. Association of Intrastrain Phase Variation in Quantity of Capsular Polysaccharide and Teichoic Acid With Virulence in Streptococcus pneumoniae. J. Infect. Dis. 177: 368-377, 1998.

104) KINDI, M.A; MUNDY, J; SULLIVAN, T; SMITH, W; KETTE, F; SMITH, A, et al. Utility of Peripheral Blood B Cell Subsets Analysis In Common Variable Immunodeficency. Clin Exp. Immunol. 167: 275-281, 2012

105) KNERR V, GRIMBACHER B.Primary Immunodeficiency Registries. Curr Opin Allergy ClinImmunol.7(6):475-480, 2007.

106) KO, J; RADIGAN, L; CUNNINGHAM-RUNDLES, C. Immune Competence and Switched Memory B Cells in Common Variable Immunodeficiency. J Clin Immunol. 116:37-41, 2005.

107) KOKRON, C.M; ERRANTE, P.R; BARROS, M.T; BARACHO, G.V; CAMARGO, M.M; KALIL, J, et al. Clinical and Laboratory Aspects of Common Variable Immunodeficiency. An Acad Bras Cienc. 76(4): 707-726, 2004.

108) KREIJZ, J.H.C.M; FOUCHIER, R.A.M; RIMMELZWAAN, G.F. Immune Responses to Influenza Virus Infection. Virus Research. 162: 19-30, 2011.

109) KUBOTA-KOKETSU, R; YUNOKI, M; OKUNO, Y; IKUTA, K. Significante Neutralizing Activities Against H2N2 Viruses in Human Intravenous Immunoglobulin Lots Manufacted from 1993 to 2010. Biologics. 6: 245-247, 2012.

110) KUIJIPERS, T.W; BENDE, R.J; BAARS, P.A; GRUMMELS, A; DERKS, I.A; DOLMAN, K.M, et al. CD20 Deficiency In Humans Results In Impaired T CellIndependent Antibody Responses. J Clin Invest. 120:214-222, 2010.

111) KURIBAYASHI, J.S; BOMBARDIERI, C.R; BARACHO, G.V; ALIBERTI, J; MACHADO, F.S; KALIL, J, et al. Slower Rescue of Homeostasis by the Unfolded Protein Response Pathway Associated With Common Variable Immunodeficiency. Mol Immunol. 45(10): 2990-2997, 2008. 
112) KUROSAKI, T. B Lymphocyte Biology. Immunol. Review. 237: 5-9, 2010.

113) LA CAVA A. Common Variable Immunodeficiency: Two Mutations Are Better Than One. J. Clin Investigation. 123:4142-4143, 2013

114) LAVALLADE, H.D; GARLAND, P; SEKINE, T; HOSCHLER, K; MARIN, D; STRINGARIS, K, et al. Repeated Vaccination is required to Optimize Seroprotection Against H1N1 in Immunocompromised Host. Haematologica. 96 (2): 307-314, 2011.

115) LAWRENCE T.C. Avaliação das subpopulações de linfócitos B em pacientes com Imunodeficiência Comum Variável [dissertação]. São Paulo: Universidade Federal de São Paulo; 2009.

116) LEIVA, L.E; ZELAZCO, M; OLEASTRO, M; CARNEIRO-SAMPAIO, M; CONDINO-NETO, A; COSTA-CARVALHO, B.T, et al. Primary Immunodeficiency Diseases in Latin America: The Second Report of the LAGID ${ }^{1}$ Registry. J Clin Immunol. 27(1): 101-108, 2007.

117) LINDROTH, K. Maturation of Humoral Immune Responses Studies on the Effects of Antigen Type, Apoptosis and Age. Tese de Doutorado. Estocolmo (Suiça): Universidade de Estocolmo, 2004.

118) LOPES-DA-SILVA, S; RIZZO, L.V. Autoimmunity in Common Variable Immunodeficiency. J Clin Immunol. 28(1):546-555, 2008.

119) LOPES-HERRERA,G; TAMPELLA， G; PAN-HAMMARSTROM， Q; HERHOLZ, P; TRUJILLO-VARGAS, C.M;PHADWAL,, K, et al. Deleterious Mutations in LBRA Are Associated with a Syndrome of Immune Deficiency and Autoimmunity. Am. J. Hum. Genet. 90: 986-1001, 2012.

120) LORENZE, E; MIRA, J; CORNISH, K; ARBOUR, N; SCHWARTZ, D.A. A Novel Polimorfism in the Toll-Like Recpetor 2 Gene and its Potential Association With Streptococcal Infection. Infect Immun. 68: 6398-6401, 2000.

121) LUND, J.M; ALEXOPOULOU, L; SATO, A; KARROW, M; ADAMS, N.C; GALE, N.W, et al. Recognition of Single-Stranded RNA Viruses by Toll-Like Receptor 7. Proc. Natl. Acad. Sci. U.S.A. 101(15): 5598-5603, 2004.

122) MACHADO, A.A. Imunogenicidade da Vacina Contra o Vírus da Influenza Sazonal em Crianças e Adolescentes Infectados e Não Infectados pelo Vírus da Imunodeficiência Humana. Dissertação de Mestrado. São Paulo (SP): Faculdade de Medicina da Universidade de São Paulo, 2010. 
123) MACKAY, F; SCHNEIDER, P; RENNERT, P; BROWNING, J. BAFF; APRIL: A Tutorial on B Cell Survival. Ann Rev Immunol. 21: 231-264, 2003.

124) MALIK, J.S; PEIRIS, L.L.M; POON, Y.G. Emergence of a Novel SwineOrigin Influenza A Virus (S-OIV) H1N1 Virus In Humans. J. Clin Virology. 45(3): 169-173, 2009.

125) MALlEY, R. Antibody and Cell-mediated Immunity to Streptococcus pneumoniae: Implications for Vaccine Development. J. Mol. Med. 88: 135-142, 2010.

126) MARINHO, A.K.B.B. Avaliação da Resposta Clínica e Humoral dos Pacientes Portadores de Imunodeficiência Comum Variável Submetidos a Vacinação com Antígenos Protéicos e Polissacarídeos. Dissertação de Mestrado. São Paulo (SP): Faculdade de Medicina da Universidade de São Paulo, 2012.

127) MANTESE, C.O; DE PAULA, A; ALMEIDA, V.V.P; AGUIAR, P.A.D.F; WOLKERS, P.C.B; ALVARES, J.R, et al. Prevalência de Sorotipos e Resistência Antimicroiana de Cepas Invasivas do Pneumococo em Crianças: Análise de 9 Anos. J. Pediatric. 85(6):495-502, 2009.

128) MARTIM, F; KEARNEY, J. Marginal Zone B Cells. Nature Review. 2: 323$335,2002$.

129) MICHEL, M; CHANET, V; GALICIER, L; RUIVARD, M, LEVY, I; HERMINE, O, et al. Autoimmune Thrombocytopenic Purpura and Common Variable Immunodeficiency. Medicine. 83:254-263, 2004.

130) MOIR, S; MALASPINA, A; OGWARO, K.M; DONOGHUE, E.T; HALLAHAN, C.W; EHLER, L.A, et al. HIV-1 Induces Phenotypic and Functional Pertubations of B Cells in Chronically Infected Individuals. Proc Natl Acad SCI USA. 98: 10362-10367, 2001.

131) MORBACH, H; EICHHORN, E.M; LIESE, J.G; GIRSCHICK, H.J. Reference Values for B Cell Subpopulations from Infancy to Adulthood. Clin Exp Immunol. 162(2): 271-279, 2010.

132) MORETTI, G.R.F; PEREIRA, J.L; SAKAE, T.M; SILVA, R.M.D. Vacina Pneumocóccica: Histórico, Indicações Clássicas e Efeitos Indiretos.Pulmão RJ.16(2-4): 91-96, 2007

133) MORIO, T. Common Variable Immunodeficiency. Nihon Rinsho. 70(11): 2011-2021, 2012. 
134) MOUILOT, G; CARMAGNAT, M; GÉRARD, L; GARNIER, J; FIESCHI, C; VINCE, N, et al. B Cell and T Cell Phenotypes In CVID Patients Correlate With the Clinical Phenotype of the Disease. J Clin Immunol. 30: 746-755, 2010.

135) MURAMATSU, M; KINOSHITA, K; FAGARASAN, S; YAMADA, S; SHINKAI, Y; HONJO, T. Class Switch Recombination and Hypermutation Require Activation-Induced Cytidine Deaminase (AID), a Potential RNA Editing Enzyme. Cell. 102(5): 553-563, 2000.

136) MURPHY, B.R; WEBSTER, R.G. Orthomyxoviruses. In: Virology. Philadelphia: Raven Pub, 1996. p.

137) MURPHY, K; TRAVERS, P; WALPORT, M. Manipulação da Resposta Imune. In: ImunoBiologia. Porto Alegre: ArtMed, 2010. p 685-697.

138) MUSCARITOLI, M; FANFARILLO, F; LUZI, G; SIRIANNI, M.C; LEBBA, F; LAVIANO, A, et al. Impaired Nutritional Status In Common Variable Immunodeficiency Patients Correlates With Reduced Levels of Serum IgA and of Circulating CD4+ T Lymphocytes. Eur J. Clin. Invest. 31(6): 544-549, 2001.

139) NOBRE, F.A; GONZÁLES, I.G.S; MELO, K.M; DANTAS, E.O; LAWRENCE, T.C; NUDELMAN, V, et al. Efficacy of Immunoglobulin Therapy In Reducing Pneumonia In Patients With Antibody Deficiencies. Rev Bras. Allerg. Immunopatol. 31(1): 2012.

140) OLIVER, A.M; MARTIN, F; KEARNEY, J.F. IgM ${ }^{\text {hight }} \mathrm{CD} 21^{\text {hight }}$ lymphocytes enriched in the splenic marginal zone generate effector cells more rapidly than bulk of follicular B cells. J. Immunol. 162:7198-7207, 1999.

141) ORANGE, J.S; BELOHRADSKY, B.H; BERGER, M; BORTE, M; HAGAN, J; JOLLES, $\mathrm{S}$, et al. Evaluation of correlation between dose and clinical outcomes in subcutaneous immunoglobulin replacement therapy. Clin. Exp. Immunol. 169(2): 172181, 2012.

142) Organização Mundial da Saúde. OMS (2009). World now at the start of 2009 Influenza pandemic. Disponível em: http://www.who.int/mediacentre/news/statements/2009/h1n1_pandemic_phase6_20090 611/en/index.html.

143) Organização Mundial da Saúde. OMS (2011). Global Alert and Response. Disponível em: http://www.who.int/csr/en/index.html. 
144) PALESE, P; SHAW, M.L. Virology. Philadelphia: Raven Pub, 2007. p. 16471680.

145) PARK, M.A; LI, J.T; HAGAN, J.B; MADDOX, D.E; ABRAHAM, R.S. Common Variable Immunodeficiency: a new look at an old disease. Lancet. 372: 489$502,2008$.

146) PEDERSEN, G; HALSTENSEN, A; SJURSEN, H; NAESS, A; KRISTOFFENSEN, E.K; COX, R.J. Pandemic Influenza Vaccination elicits influenzaspecific CD4+ Th1-cell responses in hypogammaglobulinaemic patients: four cases reports. Scand J Immunol. 74(2): 210-218, 2011

147) PEDRESCHI, M. Classificação de pacientes com Imunodeficiência Comum Variável através da identificação de subtipos de Linfócitos B. Dissertação de Mestrado. São Paulo (SP): Faculdade de Medicina da Universidade de São Paulo, 2011.

148) PIEDRA, P.A; GLAGLANI, M.J; RIGGS, M; HERSCLER, G; FEWLASS, C; WATTS, M. Live attenuated influenza vaccine, trivalent, is safe in healthy children 18 months to 4 years, 5 to 9 years and 10 to 18 years of age in a community based, nonrandomized, open-label trial. Pedriatrics. 116: 397-407, 2005.

149) PINNA, D; CORTI, D; JARROSSAY, D; SALLUSTO, F; LANZAVECCHIA, A. Clonal Dissection of the Human Memory B cell Repertoire Following Infection and Vaccination. Eur.J. Immunol. 39:1260-1270, 2009.

150) PINCHUK, L.M; KLAUSS, S.J; MAGALETTI, M; PINCHUK, G.V; NORSEN, J.P; CLARK, E. A. Functional CD40 Ligand Expressed by Human Blood Dendritic Cell is Up-Regulated by CD4 Ligation. J Immunol. 157:4363-4370, 1996.

151) QUINTI, I; SORESINA, A; SPADARO, G, MARTINO, S; DONNANNO, S; AGOSTINI, C, et al. Long-term follow-up andoutcome of a large cohort of Patients with Common Variable Immunodeficiency. J Clin Immunol. 27(3): 308-316, 2007.

152) RAKHMANOV, M, KELLER, B; GUTENBERG, S; FOERSTER, C, HOENIG, M; DRIESSEN, G, et al. Circulating CD21low B cells in Common Variable Immunodeficiency Resemble Tissue Homing, Innate-Like B cells. PNAS. 106 (32): 13451-13456, 2009. 
153) RAKHMANOV, M; GUTENBERGER, S; KELLER, B; SCHLESIER, M; PETER, H.H; WARNATZ, K. CD21low B Cells in Common Variable Immunodeficiency Do Not Show Defcts in Receptor Editing, But Resemble Tissue-Like Memory B Cells. Blood. 116 (18): 3682-3683, 2010

154) RAMÍREZ-VARGAS, N; ARABLIN-OROPEZA, S.E; MOJICA-MARTÍNEZ, D; YAMAZAKI-NAKASHIMADA, M.A; GARCIA-CRUZ, M.D.L.L; TERÁNJUÁREZ, L.M, et al. Clinical and Immunological features of Common Variable Immunodeficiency in Mexican patients. Allergol. Immunophatol. 489: 1-6, 2013.

155) RESNICK, E.S; MOSHIER, E.L; GODBOLD, J.H; CUNNINGHAMRUNDLES. Morbidity and Mortality in Common Variable Immunodeficiency over 4 decades. Blood. 119(7): 1650-1657, 2012

156) REZAEI, N; AGHAMOHAMMADI, A; MOIN, M; POURPAK, Z; MOVAHEDI, M; GHARAGOZLOU, M, et al. Frequency and Clinical Manifestations of Patients with Primary Immunodeficiency Disorders in Iran: Update from the Iranian Primary Immunodeficiency Registry. J ClinImmunol. 26: 519-526, 2006.

157) REZAEI, N; AGHAMOHAMMADI, A; SIADAT, S.D; MOIN, M; POURPAK, Z; NEJATI, M, et al. Serum Bactericidal Antibody Response to Meningococcal Polysaccharide Vaccination as a Basis for Clinical Classification of Common Variable Immunodeficiency. J ClinVaccine Immunol. 2008; 15(4): 607-611.

158) RUBINS, J.B; PURI, A.K.G; LOCH, J; CHARBONEAU, D; MACDONALD, R; OPSTAD, A, et al. Magnitude, duration, quality and function of pneumococcal vaccine responses in elderlt adults. J. Infect. Dis. 178(2): 431-440, 1998.

159) SALZER, E; SANTOS-VALENTE, E; KLAVER, S; BAN, S.A; EMMINGE, W; PRENGEMANN, N.K, et al. B Cell Deficiency and Severe Autoimmunity Caused by Deficiency of Protein Kinase C-Delta. Blood. 121: 3112-3116, 2013.

160) SALZER, E.U; WARNATZ, K; HANS HARTMUT, P. Common Variable Immunodeficiency - an update. Arthritis Reserch Therapy. 14: 223 - 234, 2012.

161) SALZER, U; MAUL-PAVICIC, A; CUNNINGHAM-RUNDLES, C; URSCHEL, S; BELOHRADSKY, B.H; LITZMAN, J, et al. ICOS Deficiency in Patients With Common Variable Immunodeficiency. J Clin Immunol. 113(3): 234$240,2004$. 
162) SAXON, A; KELD, B; SANCHÉZ-DIAZ, D; GUO, B,C; SIDELL, N. B cells from distinct subset of patients with Common Variable Immunodeficiency (CVID) have increased CD95(Apo 1/fas) diminished CD38 expression and undergo enhanced apoptosis. Clin Exp Immunol. 102:17-25, 1995.

163) SÁNCHEZ-RAMÓN, S; RADIGAN, L; YU, J.E; BARD, S; CUNNINGHAMRUNDLES, C. Memory B Cells in Common Variable Immunodeficiency: Clinical Associations and Sex Differences. NIH Public Access. 128(3): 314-321, 2008.

164) ASAKI, Y; CASOLA, S; KUTOK, J.L; RAJEWSKY, K; SCHMIDTSUPPRIAN, M. TNF family member B cell - activating factor (BAFF) receptor dependent and independent roles for BAFF in B cell physiology. J Immunol. 173(4): 2245-2252, 2004

165) SCHAFFER, A.A; PFANNSTIEL, J; WEBSTER, A.D; PLEBANI, A; HAMMARSTROM, L; GRIMBACHER, B. Analysis of families with Common Variable Immunodeficiency (CVID) and IgA deficiency suggests linkage of CVID to chromosome 16q. Hum Genet. 118:725-729, 2006.

166) SCHAFFER, A.A; SALZER, U; HAMMARSTROM, L; GRIMBACHER, B. Deconstructing Common Variable Immunodeficiency by Genetic Analysis. Curr Opin Genet. 17(3): 201-212, 2007.

167) SCHNEIDER, P. The role of APRIL and BAFF in lymphocyte activation. Curr Opin Immunol. 17(3): 282-289, 2005.

168) SCHOREDER, H.W. Jr; ZHU, Z.B; MARCH R.E; CAMPBEL, R.D; BERNEY, S.M; NEDOSPASOV, S.A, et al. Susceptibility locus for IgA deficiency and Common variable Immunodeficiency in the HLA-DR3, -B8, -A1 haplotypes. Mol Med. 4:72-86, 1998.

169) SCHWARTZ, R; PORAT, Y.B; AHANDZEL, Z; STHOEGER, Z; GARTY, B.Z; CONFINO-COHEN, R, et al. Identification of a Subset of Common Variable Immunodeficiency Patients with Impared B Cell Protein Tyrosine Phosphorylation. Clin Diagn Lab Immunol. 6: 856-860, 1999.

170) SCOTT-TAYLOR, T.H; GREE, M.R.J; EREN, E; WEBSTER, A.D.B. Monocyte Derived Dentritic Cell Responses in Common Variable Immunodeficiency. J Clin Exp Immunol. 138: 484-490, 2004. 
171) SHEARER, W.T; FLEISHER, T.A; BUCLEY, R.H; BALLAS, C.Z; BALLOW, M.D; BLAESE, M, et al. Recommendations for Live and Bacterial Vaccines in Immunodeficient Patients and Their Close Contact. J. Allerg. Clin. Immunol. 133: 961-966, 2014

172) SHULGA-MORSKAYA, S; DOBLES, M; WALSH ME, N.G. L.G; MACKAY, F; RAO, S.P; KALLED, S.L; SCOTT, M.L B cell activating factor belonging to the TNF family acts through separate receptors to support B cell survivor and independent antibody formation. J Immunol. 173(4): 2331-2341, 2004.

173) SMITH, N.M; BRESEE, J.S; SHAY, D.K; UYEKI, T.M; COX, N.J; STRIKAS, R.A. Prevention and control of Influenza: recommendations of the Advisory Committee of Immunization Practices (ACIP). MMWR Recomm. 55:1-42, 2006SNELLER, M.C. Common Variable Immunodeficiency. J Med Sci. 321:42-48, 2001.

174) SOUZA, F.A.C; BARROS, M.T; RIZZO, L.V; KALIL, J.E.F; KOKRON, C.M. Lymphocyte Proliferation with Tetanus Toxoid After Immunization in Patients with Common Variable Immunodeficiency. In: CSI Primary Immunodeficiency Diseases Consortium Conference, 2007, San Diego.

175) SPICKETT, G.P; WEBSTER, A.D; FARRANT, J. Celular Abnormalities in Common Variable Immunodeficiency. Immunodefic Rev. 2:199-219, 1990.

176) STOCKWIN, L.H; MCGONAGLE, D; MARTIN, I.G; BLAIR, G.E. Dendritic Cells: Immunological Sentinels with a Central Role in Health and Disease. Immunol Cell Biol. 78: 91-102, 2000.

177) SUCCI, R.C; FARTHAT, C.K. Vaccination in special situations. J. Pediatr. 82(3): 91-100, 2006.

178) TARALDSRUD, E; FEVANG, B; AUKRUST, P; BEISKE, K.H; FLOISAND, Y; FROLAND, S, et al. Common Variable Immunodeficiency: normal generation of naturally occurring dendritic cells that respond to Toll-Like receptors 7 and 9. Clin Exp. Immunol. 175: 439-448, 2013.

179) TAUBEBBERGER, J.K; REID, A.H; JANCZEWKSI, T.A; FANNING, T.G. Integrating historical, clinical and molecular genetic data in order to explain the origin and virulence of the 1918 Spanish influenza virus. Trans R. Soc. Lond. B. Biol. Sci. 356: 1857-1859, 2001. 
180) TAUNAY, A.E; AUSTRIAN, R; LANDGRAF, L.M; VIERA, M.F.P; MELLES, C.E.A. Sorotippos de Streptococcus pneumoniae Isolados de Líquido Cefaloraquidiano no Período de 1977-1988 na Cidade de São Paulo, Brasil. Rev. Inst. Med. Trop. 32(1): 11-15, 1990.

181) TONNAER, E.L.G.M; GRAAMANS, K; SANDERS, E.A.M; CURFS, J.H Advances in understanding the pathogenesis of pneumococcal otitis media. Pediatr. Infect. Dis. 25: 546-552, 2006

182) TORTORA, G.J; FUNKE, B.R; CASE, C.L. Microbiologia. Porto Alegre: Artmed, 2005.

183) THIEL, J; KIMMIG，L; SALZER，U; GRUDZIEN， M; LEBRECHT，D; HAGENA, $\mathrm{T}$, et al. Genetic CD21 deficiency is associated with hypogammaglobulinemiae. J Allergy Clin Immunol. 129:801-810, 2012.

184) THOMPSON, J.S; BIXLER, S.A; QUIAN, F, VORA, K; SCOTT, M.L; CACHERO, T.G, et al. BAFF-R, A Newly Identified TNF Receptor That Specifically Interacts With BAFF. Science. 293: 2108-2111, 2001

185) THON, V; WOLF, H.M; SASGARY, M; LITZMAN, J; SAMSTAG, A; HAUBER, I, et al., Defective integration of activating signals derived from the $\mathrm{T}$ cell receptor (TCR) and costimulatory molecules in both CD4+ and CD8+ T lymphocytes of Common Variable Immunodeficiency (CVID) patients. Clin Exp. Immunol. 110:174$181,1997$.

186) TOUW, C.M; VAN DE VEN, A.A; DE JONG, P.A; TERHEGGEN-LAGRO, S; BEEK, E; SANDERS, E.A, et al. Detection of pulmonary complications in Common Variable Immunodeficiency. Pediatr Allergy Immunol. 21(5): 793-805, 2010.

187) TRUJILlO, C.M; MUSKUS, C; ARANGO, J; PATINO, P.J; MONTOYA, C.J. Quantitative and Functional Evaluation of Innate Immune Responses in Patients with Common Variable Immunodeficiency. J. invest. Allergol Clin Immunol. 21(3): 207$215,2011$.

188) VAN ASSEN, S; HAAN, A.D; HOLVAST, A; HORST, G; GORTER, L; WESTRA, J, et al. Cell-Mediated Immune Responses to inactivated trivalent InfluenzaVaccination are Decreased in in patients with Common Variable Immunodeficiency.

Clin. Immunol. 141: 161-168, 2011. 
189) VAN ZELM, M.C; REISLI, I; VAN DER BURG, M; CASTAÑO, D; VAN NOESEL, C.J; GRIMBACHER, B, et al. An Antibody deficiency syndrome due to mutations in the CD19 gene. N Engl J Med. 354: 1901-1912, 2006.

190) VAN ZELM, M.C; SMET, J; ADAMS, B; MASCART, F; SCHANDENÉ, L; JANSSEN, F, et al. CD81 gene defect in humans disrupts CD19 complex formation and leads to antibody deficiency. J Clin Invest. 120: 1265-1274, 2010.

191) VASCONCELOS, D.M.; DUARTE, A.J.S. Imunodeficiência Comum Variável (hipogamaglobulinemia de inicio tardio ou hipogamaglobulinemia adquirida): breve revisão. Rev Bras Alergia Imunopatol. 12: 147-157, 1989

192) VESIKARI,T; WYSOCKI, J; CHEVALIER, B. Immunogenicity of the 10Valent Pneumococcal Non-Typeable Haemophilus influenzae Protein D Conjugate Vaccine (PHiD-CV) Compared to the Licensed \&-Valent Vaccine. The Pediatric. Inf. Dis. 28:S664, 2009.

193) VIALLARD, J.F; CAMOU, F; ANDRÉ, M; LIFERMAN, F; MOREAU, J.F; PELLEGRIN, J.L, et al. Altered Dendritic Cell Distribution in Patients With Common Variable Immunodeficiency. Arthritis Res Ther. 7(5):1052-1055, 2005.

194) VLKOVÁ, M; FRONKOVA, E; KANDEROVÁ, V; JANDA, A; RUZICKOVÁ, S; LITZMAN, J, et al. Characterization of Lymphocyte Subsets in Patients with Common Variable Immunodeficiency Reveals Subsets of Naïve Humans B cells marked by CD24 Expression. J Immunol. 185: 6431-6438, 2010.

195) WARNATZ, K; SCHLESIER, M. Flowcytometric Phenotyping of CommonVariable Immunodeficiency. Clin Cytometry. 74B: 261-271, 2008.

196) WARNATZ, K; WEHR, C; DRÄGER, R; SCHMIDT, S; HERMANN, E; SCHLESIER, M, et al. Expansion of CD19hi $\mathrm{CD} 21^{1 / \mathrm{l} \text { neg }} \mathrm{B}$ cells in Common Variable Immunodeficiency (CVID) Patients With Autoimmune Citopenia. Immunobiology. 206: 502-513, 2002.

197) WEBSTER, A,D.B. Common Variable Immunodeficiency. Humoral Immunodeficiencies. Immunol Allerg.Clin North Ame. 21: 1-22, 2001.

198) WEHR, C; EIBEL, H; MASILAMANI, M; ILLGES, H; SCHLESIER, M, PETER, H.H, et al. A new CD21 ${ }^{\text {low }}$ B Cell Population in the Peripheral Blood of Patients With SLE. J. ClinImmunol. 113: 161-171, 2004. 
199) WEHR, C; KIVIOJA, T; SCHMITT, C; FERRY, B; WITTE, T; EREN, E, et al. The EUROclass Trial: Defining Subgroups in Common Variable Immunodeficiency. Blood. 11: 77-85, 2008.

200) WEKSLER, M.E. Changes in the B cell repertoire with age. Vaccine. 18:1624$1628,2000$.

201) WELLER, S; BRAUN, M.C; TAN, B.K; ROSENWALD, A; CORDIER, C; CONLEY, M.E, et al. Human Blood IgM "Memory" B Cells are Circulating Splenic Marginal Zone B Cells Harboring a Prediversified Immunoglobulin Repertoire. Blood. 104: 3647-3654, 2004.

202) WRIGHT, P.T; NEUMANN, G; KAWAOKA K. Orthomyxoviruses. In:Virology. Philadelphia: Raven Pub, 2007. p.1691-1732.

YARMOHAMMADI, $\mathrm{H}$; ESTRELLA, L; DOUCETTE, $\mathrm{J}$; CUNNINGHAMRUNDLES. Recognizing Primary Immune Deficiency in Clinical Practice. Clin Vaccine Immunol. 13: 329-332, 2006.

203) YUNOKI, KUBOTA-KOKETSU, R; URAYAMA ， T; SASAKI， T; ANALIWA, T; KONOSHIMA, Y, et al. Significant Neutralizing Activity of Human Immunoglobulin Preparations Pandemic 2009 H1N1. Br J Haematol. 148: 948-963, 2009.

204) ZAND,M.S. Safety and efficacy of Influenza vaccination in renal transplant recipients. Nat. Clin Pract. Nepbrol. 4:358-359, 2008. 
Anexo 1: Termo de Consentimento Livre e Esclarecido

\author{
HOSPITAL DAS CLÍNICAS \\ DA \\ FACULDADE DE MEDICINA DA UNIVERSIDADE DE SÃO PAULO \\ TERMO DE CONSENTIMENTO LIVRE E ESCLARECIDO \\ (Instruções para preenchimento no verso)
}

\title{
I - DADOS DE IDENTIFICAÇÃO DO SUJEITO DA PESQUISA OU RESPONSÁVEL LEGAL \\ 1.NOME DO PACIENTE
}

DOCUMENTO DE IDENTIDADE № :

SEXO:.$M \quad F$

DATA NASCIMENTO:

№

APTO:

BAIRRO.

CIDADE

CEP:. TELEFONE:DDD

)

2.RESPONSÁVEL LEGAL

NATUREZA (grau de parentesco, tutor, curador etc.)

DOCUMENTO DE IDENTIDADE :

SEXO: $M \square F \square$

DATA NASCIMENTO.:

ENDEREÇO:

№ APTO:

BAIRRO: CIDADE:

CEP: TELEFONE:DDD ..).

II - DADOS SOBRE A PESQUISA CIENTÍFICA TÍTULO DO PROTOCOLO DE PESQUISA : Avaliação da resposta celular à imunização anti-infecciosa de pacientes com Imunodeficiência Comum Variável.

1. PESQUISADOR: Cristina Maria Kokron

2. CARGO/FUNÇÃO: Médica Assitente HC-FMUSP INSCRIÇÃO CONSELHO REGIONAL N: CRM 49888

3. UNIDADE DO HCFMUSP: Disciplina de Alergia e Imunopatologia 
3. AVALIAÇÃO DO RISCO DA PESQUISA:

$\begin{array}{llll}\text { SEM RISCO } & \text { RISCO MÍNIMO } & \mathbf{X} & \text { RISCO MÉDIO } \\ & \text { RISCO BAIXO } & & \text { RISCO MAIOR }\end{array}$

(probabilidade de que o indivíduo sofra algum dano como consequência imediata ou tardia do estudo)

\section{DURAÇÃO DA PESQUISA : 1 ano \\ III - REGISTRO DAS EXPLICAÇÕES DO PESQUISADOR AO PACIENTE OU SEU REPRESENTANTE LEGAL SOBRE A PESQUISA, CONSIGNANDO:}

1. Justificativa e os objetivos da pesquisa:

O senhor (a) tem uma doença na qual não existe produção de algumas substâncias que normalmente protegem as pessoas das infecções. Estas substâncias são chamadas anticorpos ou imunoglobulinas. No caso da sua doença, a Imunodeficiência Comum Variável, o seu organismo, por um motivo que nós ainda desconhecemos, deixou de produzir estas imunoglobulinas. Por causa disto, o senhor (a) começou a apresentar várias infecções, e, para proteger-se destas infecções é necessário repor estes anticorpos, que fazemos administrando imunoglobulinas, por via venosa, uma vez por mês. Este tratamento é feito gratuitamente no Hospital das Clínicas. Mas para estudarmos melhor a causa desta doença e eventualmente descobrirmos um tratamento mais específico e eficiente, gostaríamos de avaliar a sua capacidade de responder a vacinas. Para esta avaliação serão necessárias coletas de 3 amostras de sangue, uma antes, a segunda de 1 a 2 meses após e a terceira, 1 ano após a vacinação para realizarmos algumas análises científicas. A vacina que o senhor (a) vai receber não apresenta nenhum risco. Em consequência da sua doença, não sabemos se as vacinas conseguirão protegê-lo das infecções e é exatamente isto que queremos estudar.

2. Procedimentos que serão utilizados e propósitos, incluindo a identificação dos procedimentos que são experimentais (explicitar):

Colheremos $30 \mathrm{ml}$ de sangue ( 3 colheres de sopa) por duas vezes, uma antes e uma um mês após a vacinação, e faremos a pesquisa da resposta imunológica após contato com a vacina.

Desconfortos e riscos esperados:

Apenas aqueles relacionados à punção venosa e à vacinação.

3. Benefícios que poderão ser obtidos: (explicitar):

Entendendo melhor a doença, podemos tentar encontrar um tratamento mais eficiente.

4. Procedimentos alternativos que possam ser vantajosos para o indivíduo: não há

\section{IV - ESCLARECIMENTOS DADOS PELO PESQUISADOR SOBRE GARANTIAS DO SUJEITO DA PESQUISA:}

1) Serão dadas, a qualquer tempo, informações sobre os testes de laboratório, riscos e benefícios relacionados à pesquisa, inclusive para esclarecer qualquer dúvida. 
O Senhor(a) será informado (a) durante toda a duração da pesquisa e irá receber todas as informações por escrito onde constem os riscos e benefícios para que não fique nenhuma dúvida quanto à sua participação nela.

2) O paciente poderá retirar seu consentimento a qualquer momento e deixar de participar do estudo, sem que isto lhe traga qualquer prejuízo.

O senhor(a) poderá sair do estudo a qualquer momento que quiser sem que isto acarrete qualquer prejuízo em seu atendimento de rotina no ambulatório.

3) Haverá confidencialidade, sigilo e privacidade sobre as informações e resultados de exame.

Seus dados pessoais e resultados de exames serão guardados de forma sigilosa, deixando a sua privacidade assegurada.

4) Haverá assistência no HCFMUSP, por eventuais danos à saúde, devidos a pesquisa.

Está garantida assistência médica no Serviço de Imunologia e Complexo Hospital das Clínicas, caso ocorram problemas de saúde decorrentes da pesquisa.

5) Possibilidade de indenização por eventuais danos à saúde decorrentes da pesquisa.

Como o risco de ocorrer algum dano decorrente desde estudo é mínimo, não está prevista indenização.

\section{INFORMAÇÕES DE NOMES, ENDEREÇOS E TELEFONES DOS RESPONSÁVEIS PELO ACOMPANHAMENTO DA PESQUISA, PARA CONTATO EM CASO DE INTERCORRÊNCIAS CLÍNICAS E REAÇÕES ADVERSAS.}

Dr(a) Cristina Maria Kokron 3069-5914; 3069-6225; 3069-6098; 9981-3852

\section{OBSERVAÇÕES COMPLEMENTARES:}

\section{II - CONSENTIMENTO PÓS-ESCLARECIDO}

Declaro que, após convenientemente esclarecido pelo pesquisador e ter entendido o que me foi explicado, consinto em participar do presente Protocolo de Pesquisa

São Paulo, de de 2011 . 
Anexo 2: Aprovação da Cappesq

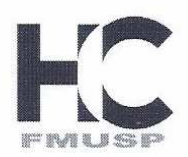

Ao

Departamento de Clinica Médica

O Coordenador da Comissão de Ética para Análise de Projetos de Pesquisa-CAPPesq da Diretoria Clínica do Hospital das Clínicas da Faculdade de Medicina da Universidade de São Paulo, APROVOU adreferendum em 04.06.13 a execução do subprojeto intitulado "Avaliação do perfil dos linfócitos B de pacientes com Imunodeficiência Comum Variável antes e após administração de antígenos protéicos e polissacaridicos", que será Doutorado da aluna Maíra Pedreschi, tendo como orientadora a Dra. Cristina Maria Kokron.

O referido projeto faz parte do Protocolo de Pesquisa $n^{\circ}$ 0460/06, intitulado "Avaliação da resposta celular à imunização antiinfecciosa de pacientes com Imunodeficiência Comum variável.", tem como Pesquisador Responsável: Dra. Cristina Maria Kokron.

CAPPesq, 06 de Junho de 2013.

PROF. DR. LUIZ EUGÊNIO GARCEZ LEME Coordenador

Comissão de Ética para Análise de Projetos de Pesquisa - CAPPesq 
Anexo 3: Score de Sintomas Pré Tratamento com Reposição de Imunoglobulinas.

\begin{tabular}{|c|c|c|c|c|c|c|c|c|c|}
\hline \multicolumn{10}{|c|}{ PRÉ REPOSIC̣ÃO DE IMUNOGLOBULINAS } \\
\hline Identificação & Amigdalites & Sinusites & Pneumonias & Otite & IVAS & ATB & Hospitalizações & BQ & TOTAL \\
\hline CVID03 & 0 & 1 & 0 & 0 & 4 & 1 & 0 & 0 & 6 \\
\hline CVID04 & 0 & 5 & 3 & 0 & 5 & 3 & 0 & 5 & 21 \\
\hline CVID05 & 1 & 5 & 1 & 0 & 5 & 5 & 0 & 5 & 22 \\
\hline CVID06 & 0 & 5 & 1 & 0 & 5 & 5 & 0 & 0 & 16 \\
\hline CVID10 & 0 & 2 & 1 & 0 & 1 & 3 & 0 & 5 & 12 \\
\hline CVID12 & 0 & 5 & 2 & 0 & 5 & 5 & 2 & 5 & 24 \\
\hline CVID13 & 1 & 3 & 1 & 0 & 5 & 5 & 2 & 0 & 17 \\
\hline CVID14 & 1 & 5 & 5 & 1 & 5 & 10 & 3 & 5 & 35 \\
\hline CVID15 & 1 & 5 & 1 & 1 & 5 & 5 & 0 & 0 & 18 \\
\hline CVID16 & 1 & 5 & 5 & 0 & 5 & 8 & 0 & 5 & 29 \\
\hline CVID17 & 0 & 4 & 2 & 0 & 0 & 6 & 0 & 5 & 17 \\
\hline CVID19 & 0 & 2 & 5 & 0 & 5 & 5 & 0 & 0 & 17 \\
\hline CVID20 & 0 & 2 & 2 & 0 & 3 & 3 & 0 & 0 & 10 \\
\hline CVID21 & 2 & 5 & 5 & 0 & 5 & 10 & 0 & 5 & 32 \\
\hline CVID22 & 1 & 3 & 1 & 0 & 5 & 5 & 5 & 0 & 20 \\
\hline CVID24 & 1 & 5 & 3 & 3 & 5 & 5 & 0 & 5 & 27 \\
\hline CVID25 & 0 & 5 & 5 & 1 & 5 & 5 & 3 & 5 & 29 \\
\hline CVID26 & 0 & 5 & 5 & 1 & 5 & 5 & 0 & 5 & 26 \\
\hline CVID27 & 0 & 5 & 0 & 0 & 3 & 5 & 2 & 0 & 15 \\
\hline CVID28 & 5 & 5 & 5 & 1 & 5 & 5 & 2 & 0 & 28 \\
\hline CVID29 & 1 & 5 & 3 & 0 & 5 & 5 & 2 & 5 & 26 \\
\hline CVID30 & 0 & 2 & 2 & 0 & 1 & 2 & 0 & 0 & 7 \\
\hline CVID31 & 3 & 5 & 5 & 2 & 5 & 5 & 1 & 5 & 31 \\
\hline CVID32 & 0 & 1 & 0 & 0 & 2 & 2 & 0 & 0 & 5 \\
\hline CVID33 & 0 & 3 & 2 & 0 & 5 & 5 & 0 & 0 & 15 \\
\hline CVID34 & 1 & 5 & 5 & 0 & 5 & 10 & 1 & 5 & 32 \\
\hline CVID35 & 0 & 2 & 0 & 0 & 5 & 2 & 0 & 0 & 9 \\
\hline CVID36 & 1 & 5 & 1 & 0 & 5 & 5 & 2 & 5 & 24 \\
\hline CVID38 & 0 & 5 & 5 & 1 & 5 & 5 & 2 & 5 & 28 \\
\hline CVID39 & 2 & 5 & 1 & 0 & 5 & 5 & 1 & 5 & 24 \\
\hline CVID40 & 2 & 5 & 5 & 2 & 5 & 5 & 5 & 5 & 34 \\
\hline CVID41 & 5 & 5 & 2 & 0 & 5 & 5 & 2 & 5 & 29 \\
\hline CVID42 & 1 & 5 & 5 & 1 & 5 & 5 & 0 & 5 & 27 \\
\hline CVID43 & 1 & 1 & 0 & 0 & 1 & 3 & 0 & 0 & 6 \\
\hline CVID44 & 0 & 2 & 2 & 2 & 5 & 5 & 1 & 5 & 22 \\
\hline
\end{tabular}

IVAS: Infecções das Vias Aéreas Superiores.

ATB: Antibióticoterapia.

BQ: Bronquiectasias. 
Anexo 4: Score de Sintomas - Pré Vacinação.

\begin{tabular}{|c|c|c|c|c|c|c|c|c|c|}
\hline \multicolumn{10}{|c|}{ PRÉ VACINAÇÃO } \\
\hline Identificação & Amigdalites & Sinusites & Pneumonias & OMA & IVAS & ATB & Hospitalizações & BQ & TOTAL \\
\hline CVID03 & 0 & 1 & 0 & 0 & 3 & 2 & 0 & 0 & 6 \\
\hline CVID04 & 0 & 2 & 1 & 0 & 3 & 4 & 0 & 0 & 10 \\
\hline CVID05 & 1 & 3 & 1 & 0 & 3 & 4 & 0 & 0 & 12 \\
\hline CVID06 & 0 & 0 & 0 & 0 & 3 & 2 & 0 & 0 & 5 \\
\hline CVID10 & 0 & 1 & 0 & 0 & 1 & 1 & 1 & 0 & 4 \\
\hline CVID12 & 0 & 3 & 0 & 0 & 3 & 5 & 0 & 5 & 16 \\
\hline CVID13 & 0 & 2 & 1 & 0 & 3 & 0 & 0 & 0 & 6 \\
\hline CVID14 & 0 & 3 & 2 & 0 & 2 & 5 & 0 & 5 & 17 \\
\hline CVID15 & 0 & 5 & 1 & 0 & 5 & 5 & 0 & 0 & 16 \\
\hline CVID16 & 0 & 3 & 0 & 0 & 3 & 2 & 0 & 5 & 13 \\
\hline CVID17 & 0 & 3 & 2 & 0 & 5 & 5 & 0 & 5 & 20 \\
\hline CVID19 & 0 & 1 & 0 & 0 & 1 & 1 & 0 & 0 & 3 \\
\hline CVID20 & 0 & 0 & 1 & 0 & 2 & 1 & 0 & 0 & 4 \\
\hline CVID21 & 0 & 2 & 0 & 0 & 2 & 3 & 0 & 5 & 12 \\
\hline CVID22 & 0 & 2 & 0 & 0 & 2 & 3 & 3 & 0 & 10 \\
\hline CVID24 & 2 & 5 & 5 & 4 & 5 & 5 & 3 & 5 & 34 \\
\hline CVID25 & 0 & 3 & 1 & 0 & 3 & 3 & 0 & 5 & 15 \\
\hline CVID26 & 0 & 3 & 2 & 0 & 3 & 3 & 0 & 5 & 16 \\
\hline CVID27 & 1 & 5 & 2 & 0 & 5 & 5 & 1 & 5 & 24 \\
\hline CVID28 & 0 & 3 & 2 & 0 & 3 & 4 & 0 & 0 & 12 \\
\hline CVID29 & 0 & 5 & 5 & 0 & 5 & 5 & 1 & 5 & 26 \\
\hline CVID30 & 0 & 0 & 0 & 0 & 2 & 1 & 0 & 0 & 3 \\
\hline CVID31 & 0 & 2 & 3 & 0 & 3 & 5 & 0 & 5 & 18 \\
\hline CVID32 & 0 & 2 & 0 & 0 & 1 & 1 & 0 & 0 & 4 \\
\hline CVID33 & 1 & 3 & 0 & 1 & 3 & 5 & 0 & 5 & 18 \\
\hline CVID34 & 0 & 2 & 0 & 0 & 2 & 2 & 0 & 5 & 11 \\
\hline CVID35 & 0 & 2 & 0 & 0 & 2 & 1 & 0 & 0 & 5 \\
\hline CVID36 & 0 & 0 & 0 & 0 & 3 & 4 & 0 & 0 & 7 \\
\hline CVID38 & 0 & 5 & 0 & 0 & 5 & 5 & 1 & 5 & 21 \\
\hline CVID39 & 0 & 0 & 0 & 0 & 3 & 2 & 0 & 5 & 10 \\
\hline CVID40 & 0 & 2 & 3 & 0 & 5 & 5 & 2 & 5 & 22 \\
\hline CVID41 & 0 & 3 & 0 & 0 & 3 & 4 & 0 & 5 & 15 \\
\hline CVID42 & 1 & 1 & 0 & 0 & 1 & 2 & 0 & 5 & 10 \\
\hline CVID43 & 0 & 0 & 0 & 0 & 1 & 1 & 0 & 0 & 2 \\
\hline CVID44 & 0 & 2 & 1 & 0 & 2 & 3 & 0 & 5 & 13 \\
\hline
\end{tabular}

IVAS: Infecções das Vias Aéreas Superiores.

ATB: Antibióticoterapia.

BQ: Bronquiectasias. 
Anexo 5: Score de Sintomas Pós Vacinação.

\begin{tabular}{|c|c|c|c|c|c|c|c|c|c|}
\hline \multicolumn{10}{|c|}{ PÓS VACINAÇÃO } \\
\hline Identificação & Amigdalites & Sinusites & \begin{tabular}{|l|} 
Pneumonias \\
\end{tabular} & OMA & IVAS & ATB & Hospitalizações & BQ & Total \\
\hline CVID03 & 0 & 0 & 0 & 0 & 1 & 1 & 0 & 0 & 2 \\
\hline CVID04 & 0 & 1 & 0 & 0 & 1 & 2 & 0 & 0 & 4 \\
\hline CVID05 & 0 & 1 & 0 & 0 & 2 & 2 & 0 & 0 & 5 \\
\hline CVID06 & 0 & 0 & 0 & 0 & 1 & 0 & 0 & 0 & 1 \\
\hline CVID10 & 0 & 0 & 0 & 0 & 1 & 1 & 0 & 0 & 2 \\
\hline CVID12 & 0 & 1 & 0 & 0 & 2 & 2 & 0 & 5 & 10 \\
\hline CVID13 & 0 & 1 & 0 & 0 & 3 & 2 & 0 & 0 & 6 \\
\hline CVID14 & 0 & 1 & 1 & 0 & 2 & 3 & 0 & 5 & 12 \\
\hline CVID15 & 0 & 3 & 0 & 0 & 3 & 4 & 0 & 5 & 15 \\
\hline CVID16 & 0 & 0 & 1 & 0 & 0 & 0 & 5 & 0 & 6 \\
\hline CVID17 & 0 & 0 & 0 & 0 & 2 & 1 & 0 & 5 & 8 \\
\hline CVID19 & 0 & 1 & 0 & 0 & 1 & 0 & 0 & 0 & 2 \\
\hline CVID20 & 0 & 2 & 1 & 0 & 1 & 2 & 0 & 0 & 6 \\
\hline CVID21 & 0 & 2 & 0 & 0 & 2 & 2 & 0 & 5 & 11 \\
\hline CVID22 & 0 & 1 & 0 & 0 & 3 & 2 & 0 & 0 & 6 \\
\hline CVID24 & 0 & 1 & 0 & 0 & 1 & 2 & 0 & 0 & 4 \\
\hline CVID25 & 0 & 0 & 0 & 0 & 2 & 1 & 0 & 5 & 8 \\
\hline CVID26 & 0 & 2 & 0 & 0 & 3 & 2 & 0 & 5 & 12 \\
\hline CVID27 & 0 & 1 & 0 & 0 & 1 & 2 & 0 & 0 & 4 \\
\hline CVID28 & 0 & 1 & 0 & 0 & 2 & 1 & 0 & 5 & 9 \\
\hline CVID29 & 0 & 1 & 0 & 0 & 1 & 0 & 0 & 0 & 2 \\
\hline CVID30 & 0 & 2 & 0 & 0 & 3 & 2 & 0 & 5 & 12 \\
\hline CVID31 & 0 & 3 & 0 & 0 & 1 & 3 & 0 & 0 & 7 \\
\hline CVID32 & 0 & 0 & 0 & 0 & 2 & 2 & 0 & 0 & 4 \\
\hline CVID33 & 0 & 1 & 0 & 0 & 2 & 3 & 0 & 5 & 11 \\
\hline CVID34 & 0 & 2 & 0 & 0 & 2 & 2 & 0 & 5 & 11 \\
\hline CVID35 & 0 & 1 & 0 & 0 & 1 & 1 & 0 & 0 & 3 \\
\hline CVID36 & 0 & 0 & 0 & 0 & 0 & 1 & 0 & 0 & 1 \\
\hline CVID38 & 0 & 5 & 0 & 0 & 2 & 5 & 1 & 5 & 18 \\
\hline CVID39 & 0 & 0 & 0 & 0 & 2 & 1 & 0 & 5 & 8 \\
\hline CVID 40 & 0 & 1 & 3 & 0 & 1 & 4 & 1 & 5 & 15 \\
\hline CVID41 & 0 & 2 & 0 & 0 & 2 & 3 & 0 & 5 & 12 \\
\hline CVID42 & 0 & 1 & 0 & 0 & 1 & 3 & 0 & 5 & 10 \\
\hline CVID43 & 0 & 0 & 0 & 0 & 0 & 0 & 0 & 0 & 0 \\
\hline CVID44 & 0 & 0 & 0 & 0 & 2 & 2 & 0 & 5 & 9 \\
\hline
\end{tabular}

IVAS: Infecções das Vias Aéreas Superiores.

ATB: Antibióticoterapia.

BQ: Bronquiectasias. 
Anexo 6: Frequência dos Subtipos de Linfócitos B em Pacientes com Imunodeficiência Comum Variável - Pré Vacinação.

\begin{tabular}{|c|c|c|c|c|c|c|c|c|c|c|c|c|c|c|c|c|}
\hline \multicolumn{17}{|c|}{ Pré } \\
\hline & \multicolumn{6}{|c|}{ Basal } & \multicolumn{5}{|c|}{ Lisado Viral $20 \mathrm{ng} / \mathrm{mL}$} & \multicolumn{5}{|c|}{ HA $2,5 \mu \mathrm{g} / \mathrm{mL}$} \\
\hline & Linfócitos Totais & LB & Naive & MZB & SMB & PBL & LB & Naive & MZB & SMB & PBL & LB & Naive & MZB & SMB & PBL \\
\hline Identificação & $\%$ & $\%$ & $\%$ & $\%$ & $\%$ & $\%$ & $\%$ & $\%$ & $\%$ & $\%$ & $\%$ & $\%$ & $\%$ & $\%$ & $\%$ & $\%$ \\
\hline CVID01 & $43,10 \%$ & $4,56 \%$ & $55,90 \%$ & $18,00 \%$ & $22,70 \%$ & $0,03 \%$ & $3,67 \%$ & $52,10 \%$ & $16,00 \%$ & $26,80 \%$ & $0,02 \%$ & $2,86 \%$ & $48,70 \%$ & $19,10 \%$ & $27,80 \%$ & $0,00 \%$ \\
\hline CVID02 & $* * *$ & $* * *$ & $* * *$ & $* * *$ & $* * *$ & $* * *$ & $* * *$ & $* * *$ & $* * *$ & $* * *$ & $* * *$ & $* * *$ & $* * *$ & $* * *$ & $* * *$ & $* * *$ \\
\hline CVID03 & $29,50 \%$ & $3,89 \%$ & $49,20 \%$ & $35,50 \%$ & $36,90 \%$ & $11,00 \%$ & $4,54 \%$ & $49,70 \%$ & $18,10 \%$ & $54,10 \%$ & $13,40 \%$ & $5,00 \%$ & $56,90 \%$ & $34,60 \%$ & $38,50 \%$ & $7,86 \%$ \\
\hline CVID04 & $30 \%$ & $4,45 \%$ & $59,40 \%$ & $57,10 \%$ & $15,70 \%$ & $11,30 \%$ & $4,32 \%$ & $42,10 \%$ & $72,80 \%$ & $1,35 \%$ & $7,20 \%$ & $2,66 \%$ & $48,60 \%$ & $54,80 \%$ & $1,19 \%$ & $2,81 \%$ \\
\hline CVID05 & $18,90 \%$ & $2,27 \%$ & $60,60 \%$ & $21,20 \%$ & $54,10 \%$ & $11,20 \%$ & $3,45 \%$ & $45,10 \%$ & $11,30 \%$ & $73,10 \%$ & $20,70 \%$ & $4,07 \%$ & $40,00 \%$ & $16,90 \%$ & $70,00 \%$ & $19,20 \%$ \\
\hline CVID06 & $15 \%$ & $5,24 \%$ & $73,80 \%$ & $11,60 \%$ & $18,10 \%$ & $8,56 \%$ & $5,03 \%$ & $73,60 \%$ & $7,84 \%$ & $23,90 \%$ & $8,59 \%$ & $5,53 \%$ & $71,60 \%$ & $9,02 \%$ & $26,10 \%$ & $6,05 \%$ \\
\hline CVID07 & $35,50 \%$ & $0,36 \%$ & $39,50 \%$ & $23,00 \%$ & $42,30 \%$ & $8,52 \%$ & $0,40 \%$ & $37,30 \%$ & $19,20 \%$ & $34,30 \%$ & $22,10 \%$ & $0,30 \%$ & $30,50 \%$ & $32,40 \%$ & $37,00 \%$ & $14,60 \%$ \\
\hline CVID08 & $40 \%$ & $4,30 \%$ & $12,30 \%$ & $32,00 \%$ & $33,00 \%$ & $4,59 \%$ & $3,71 \%$ & $24,30 \%$ & $17,50 \%$ & $43,10 \%$ & $4,92 \%$ & $2,92 \%$ & $12,80 \%$ & $21,70 \%$ & $52,50 \%$ & $6,04 \%$ \\
\hline CVID10 & $44,60 \%$ & $12,50 \%$ & $59,80 \%$ & $59,80 \%$ & $5,77 \%$ & $1,96 \%$ & $11,70 \%$ & $51,60 \%$ & $38,90 \%$ & $15,00 \%$ & $8,23 \%$ & $11,60 \%$ & $64,90 \%$ & $40,90 \%$ & $18,60 \%$ & $9,48 \%$ \\
\hline CVIDIl & $* * *$ & $* * *$ & *** & $* * *$ & *** & $* * *$ & $* * *$ & $* * *$ & *** & $* * *$ & $* * *$ & $* * *$ & $* * *$ & $* * *$ & $* * *$ & *** \\
\hline CVID12 & $39,50 \%$ & $2,84 \%$ & $3,26 \%$ & $3,46 \%$ & $81,30 \%$ & $8,13 \%$ & $2,68 \%$ & $2,36 \%$ & $1,85 \%$ & $86,80 \%$ & $2,84 \%$ & $1,72 \%$ & $3,08 \%$ & $2,62 \%$ & $88,80 \%$ & $3,93 \%$ \\
\hline CVID13 & $* * *$ & $* * *$ & $* * *$ & $* * *$ & $* * *$ & $* * *$ & $* * *$ & $* * *$ & $* * *$ & $* * *$ & $* * *$ & $* * *$ & $* * *$ & $* * *$ & $* * *$ & $* * *$ \\
\hline CVIDl4 & $26,20 \%$ & $1,95 \%$ & $7,19 \%$ & $8,10 \%$ & $78,90 \%$ & $6,95 \%$ & $2,11 \%$ & $4,01 \%$ & $5,61 \%$ & $82,50 \%$ & $2,35 \%$ & $1,44 \%$ & $5,22 \%$ & $3,75 \%$ & $85,60 \%$ & $1,81 \%$ \\
\hline CVID15 & $43,60 \%$ & $3,30 \%$ & $74,90 \%$ & $40,90 \%$ & $10,70 \%$ & $42,40 \%$ & $1,47 \%$ & $76,60 \%$ & $46,90 \%$ & $12,90 \%$ & $37,50 \%$ & $3,19 \%$ & $54,70 \%$ & $30,00 \%$ & $16,40 \%$ & $52,00 \%$ \\
\hline CVID17 & $36,30 \%$ & $7,21 \%$ & $52,50 \%$ & $0,26 \%$ & $24,00 \%$ & $22,40 \%$ & $5,50 \%$ & $49,00 \%$ & $0,13 \%$ & $46,10 \%$ & $15,70 \%$ & $4,78 \%$ & $40,40 \%$ & $0,24 \%$ & $41,60 \%$ & $12,20 \%$ \\
\hline CVID19 & $20,40 \%$ & $13,90 \%$ & $71,30 \%$ & $39,00 \%$ & $19,30 \%$ & $47,80 \%$ & $12,40 \%$ & $53,80 \%$ & $18,60 \%$ & $34,70 \%$ & $54,10 \%$ & $17,50 \%$ & $56,00 \%$ & $18,60 \%$ & $35,30 \%$ & $60,30 \%$ \\
\hline
\end{tabular}

Freqüências individuais para cada um dos 4 subtipos de LB avaliados no grupo dos pacientes com ICV nas condições basal e após a estimulação com lisado viral na concentração de 20ng/mL e hemaglutinina na concentração de 2,5 $\mu \mathrm{g} / \mathrm{mL}$. Naive: LB naive; MZB: LB de Zona Marginal; SMB: Linfócito B de memória com troca de isotipo; PBL: plasmoblastos.

***: ausência de amostra 
Anexo 7: Valores Absolutos dos Subtipos de Linfócitos B em Pacientes com Imunodeficiência Comum Variável - Pré Vacinação.

\begin{tabular}{|c|c|c|c|c|c|c|c|c|c|c|c|c|c|c|c|c|}
\hline \multicolumn{17}{|c|}{ Pré } \\
\hline & \multicolumn{6}{|c|}{ Basal } & \multicolumn{5}{|c|}{ Lisado Viral $20 \mathrm{ng} / \mathrm{mL}$} & \multicolumn{5}{|c|}{ HA $2,5 \mu \mathrm{g} / \mathrm{mL}$} \\
\hline & \begin{tabular}{|l} 
Linfócitos Totais \\
\end{tabular} & LB & Naive & MZB & SMB & PBL & LB & Naive & MZB & SMB & PBL & LB & Naive & MZB & SMB & PBL \\
\hline Identificação & Abs. & Abs. & Abs. & Abs. & Abs. & Abs. & Abs. & Abs. & Abs. & Abs. & Abs. & Abs. & Abs. & Abs. & Abs. & Abs. \\
\hline CVID01 & $2,5 \mathrm{mil} / \mathrm{mm}^{3}$ & $0,36 \mathrm{mil} / \mathrm{mm}^{3}$ & $2,10 \mathrm{mil} / \mathrm{mm}^{3}$ & $3,2 \mathrm{mil} / \mathrm{mm}^{3}$ & $0,41 \mathrm{mil} / \mathrm{mm}^{3}$ & $0,05 \mathrm{mil} / \mathrm{mm}^{3}$ & $0,34 \mathrm{mil} / \mathrm{mm}^{3}$ & $1,77 \mathrm{mil} / \mathrm{mm}^{3}$ & $2,59 \mathrm{mil} / \mathrm{mm}^{3}$ & $0,29 \mathrm{mil} / \mathrm{mm}^{3}$ & $0,17 \mathrm{mil} / \mathrm{mm}^{3}$ & $0,34 \mathrm{mil} / \mathrm{mm}^{3}$ & $1,63 \mathrm{mil} / \mathrm{mm}^{3}$ & $2,29 \mathrm{mil} / \mathrm{mm}^{3}$ & $0,37 \mathrm{mil} / \mathrm{mm}^{3}$ & $0,08 \mathrm{mil} / \mathrm{mm}^{3}$ \\
\hline CVID02 & $1,2 \mathrm{mil} / \mathrm{mm}^{3}$ & $0,06 \mathrm{mil} / \mathrm{mm}^{3}$ & $1,83 \mathrm{mil} / \mathrm{mm}^{3}$ & $1,03 \mathrm{mil} / \mathrm{mm}^{3}$ & $0,17 \mathrm{mil} / \mathrm{mm}^{3}$ & $0 \mathrm{mil} / \mathrm{mm}^{3}$ & $0,06 \mathrm{mil} / \mathrm{mm}^{3}$ & $1,67 \mathrm{mil} / \mathrm{mm}^{3}$ & $0,77 \mathrm{mil} / \mathrm{mm}^{3}$ & $0,04 \mathrm{mil} / \mathrm{mm}^{3}$ & $0,01 \mathrm{mil} / \mathrm{mm}^{3}$ & $0,04 \mathrm{mil} / \mathrm{mm}^{3}$ & $1,16 \mathrm{mil} / \mathrm{mm}^{3}$ & $1,14 \mathrm{mil} / \mathrm{mm}^{3}$ & $0,29 \mathrm{mil} / \mathrm{mm}^{3}$ & $0,05 \mathrm{mil} / \mathrm{mm}^{3}$ \\
\hline CVID03 & $1,3 \mathrm{mil} / \mathrm{mm}^{3}$ & $0,40 \mathrm{mil} / \mathrm{mm}^{3}$ & $2,84 \mathrm{mil} / \mathrm{mm}^{3}$ & $1,34 \mathrm{mil} / \mathrm{mm}^{3}$ & $0,50 \mathrm{mil} / \mathrm{mm}^{3}$ & $0,13 \mathrm{mil} / \mathrm{mm}^{3}$ & $0,21 \mathrm{mil} / \mathrm{mm}^{3}$ & $2,83 \mathrm{mil} / \mathrm{mm}^{3}$ & $1,80 \mathrm{mil} / \mathrm{mm}^{3}$ & $0,45 \mathrm{mil} / \mathrm{mm}^{3}$ & $0,37 \mathrm{mil} / \mathrm{mm}^{3}$ & $0,22 \mathrm{mil} / \mathrm{mm}^{3}$ & $2,03 \mathrm{mil} / \mathrm{mm}^{3}$ & $1,67 \mathrm{mil} / \mathrm{mm}^{3}$ & $0,20 \mathrm{mil} / \mathrm{mm} 3$ & $0,22 \mathrm{mil} / \mathrm{mm}^{3}$ \\
\hline CVID04 & $3,6 \mathrm{mil} / \mathrm{mm}^{3}$ & $0,83 \mathrm{mil} / \mathrm{mm}^{3}$ & $6,81 \mathrm{mil} / \mathrm{mm}^{3}$ & $3,14 \mathrm{mil} / \mathrm{mm}^{3}$ & $0,36 \mathrm{mil} / \mathrm{mm}^{3}$ & $0 \mathrm{mil} / \mathrm{mm}^{3}$ & $1,41 \mathrm{mil} / \mathrm{mm}^{3}$ & $4,21 \mathrm{mil} / \mathrm{mm}^{3}$ & $0,86 \mathrm{mil} / \mathrm{mm}^{3}$ & $6,22 \mathrm{mil} / \mathrm{mm}^{3}$ & $0,01 \mathrm{mil} / \mathrm{mm}^{3}$ & $1,52 \mathrm{mil} / \mathrm{mm}^{3}$ & $4,02 \mathrm{mil} / \mathrm{mm}^{3}$ & $0,62 \mathrm{mil} / \mathrm{mm}^{3}$ & $6,89 \mathrm{mil} / \mathrm{mm}^{3}$ & $0,01 \mathrm{mil} / \mathrm{mm}^{3}$ \\
\hline CVID05 & $2,3 \mathrm{mil} / \mathrm{mm}^{3}$ & $1,32 \mathrm{mil} / \mathrm{mm}^{3}$ & $1,15 \mathrm{mil} / \mathrm{mm}^{3}$ & $0,11 \mathrm{mil} / \mathrm{mm}^{3}$ & $7,66 \mathrm{mil} / \mathrm{mm}^{3}$ & $0 \mathrm{mil} / \mathrm{mm}^{3}$ & $1,64 \mathrm{mil} / \mathrm{mm}^{3}$ & $0,74 \mathrm{mil} / \mathrm{mm}^{3}$ & $0,07 \mathrm{mil} / \mathrm{mm}^{3}$ & $7,96 \mathrm{mil} / \mathrm{mm}^{3}$ & $0,02 \mathrm{mil} / \mathrm{mm}^{3}$ & $1,79 \mathrm{mil} / \mathrm{mm}^{3}$ & $0,56 \mathrm{mil} / \mathrm{mm}^{3}$ & $0,07 \mathrm{mil} / \mathrm{mm}^{3}$ & $7,93 \mathrm{mil} / \mathrm{mm}^{3}$ & $0,01 \mathrm{mil} / \mathrm{mm}^{3}$ \\
\hline CVID06 & $* * *$ & $* * *$ & $* * *$ & $* * *$ & $* * *$ & $* * *$ & $* * *$ & $* * *$ & $* * *$ & $* * *$ & $* * *$ & $* * *$ & $* * *$ & $* * *$ & $* * *$ & **** \\
\hline CVID07 & $1,6 \mathrm{mil} / \mathrm{mm}^{3}$ & $0,20 \mathrm{mil} / \mathrm{mm}^{3}$ & $0,18 \mathrm{mil} / \mathrm{mm}^{3}$ & $0,04 \mathrm{mil} / \mathrm{mm}^{3}$ & $1,33 \mathrm{mil} / \mathrm{mm}^{3}$ & $0,12 \mathrm{mil} / \mathrm{mm}^{3}$ & $0,17 \mathrm{mil} / \mathrm{mm}^{3}$ & $2,25 \mathrm{mil} / \mathrm{mm}^{3}$ & $0,08 \mathrm{mil} / \mathrm{mm}^{3}$ & $0,93 \mathrm{mil} / \mathrm{mm}^{3}$ & $0,21 \mathrm{mil} / \mathrm{mm}^{3}$ & $0,13 \mathrm{mil} / \mathrm{mm}^{3}$ & $2,17 \mathrm{mil} / \mathrm{mm}^{3}$ & $0,09 \mathrm{mil} / \mathrm{mm}^{3}$ & $0,73 \mathrm{mil} / \mathrm{mm}^{3}$ & $0,12 \mathrm{mil} / \mathrm{mm}^{3}$ \\
\hline CVID08 & $1,8 \mathrm{mil} / \mathrm{mm}^{3}$ & $1,1 \mathrm{mil} / \mathrm{mm}^{3}$ & $2,72 \mathrm{mil} / \mathrm{mm}^{3}$ & $2,28 \mathrm{mil} / \mathrm{mm}^{3}$ & $0,56 \mathrm{mil} / \mathrm{mm}^{3}$ & $1,27 \mathrm{mil} / \mathrm{mm}^{3}$ & $0,80 \mathrm{mil} / \mathrm{mm}^{3}$ & $3,39 \mathrm{mil} / \mathrm{mm}^{3}$ & $2,53 \mathrm{mil} / \mathrm{mm}^{3}$ & $0,60 \mathrm{mil} / \mathrm{mm}^{3}$ & $0,97 \mathrm{mil} / \mathrm{mm}^{3}$ & $1,09 \mathrm{mil} / \mathrm{mm}^{3}$ & $1,52 \mathrm{mil} / \mathrm{mm}^{3}$ & $1,14 \mathrm{mil} / \mathrm{mm}^{3}$ & $0,56 \mathrm{mil} / \mathrm{mm}^{3}$ & $2,98 \mathrm{mil} / \mathrm{mm}^{3}$ \\
\hline CVID10 & $2,5 \mathrm{mil} / \mathrm{mm}^{3}$ & $0,12 \mathrm{mil} / \mathrm{mm}^{3}$ & $1,75 \mathrm{mil} / \mathrm{mm}^{3}$ & $4,12 \mathrm{mil} / \mathrm{mm}^{3}$ & $0,30 \mathrm{mil} / \mathrm{mm}^{3}$ & $0,03 \mathrm{mil} / \mathrm{mm}^{3}$ & $0,12 \mathrm{mil} / \mathrm{mm}^{3}$ & $1,88 \mathrm{mil} / \mathrm{mm}^{3}$ & $2,15 \mathrm{mil} / \mathrm{mm}^{3}$ & $0,71 \mathrm{mil} / \mathrm{mm}^{3}$ & $0,08 \mathrm{mil} / \mathrm{mm}^{3}$ & $0,13 \mathrm{mil} / \mathrm{mm}^{3}$ & $1,58 \mathrm{mil} / \mathrm{mm}^{3}$ & $2,59 \mathrm{mil} / \mathrm{mm}^{3}$ & $0,51 \mathrm{mil} / \mathrm{mm}^{3}$ & $0,05 \mathrm{mil} / \mathrm{mm}^{3}$ \\
\hline CVID11 & $* * *$ & **** & $* * *$ & $* * *$ & $* * *$ & **** & $* * *$ & $* * *$ & $* * *$ & $* * *$ & $* * *$ & $* * *$ & $* * *$ & $* * *$ & **** & **** \\
\hline CVID12 & $1,9 \mathrm{mil} / \mathrm{mm}^{3}$ & $0,20 \mathrm{mil} / \mathrm{mm}^{3}$ & $1,02 \mathrm{mil} / \mathrm{mm}^{3}$ & $1,81 \mathrm{mil} / \mathrm{mm}^{3}$ & $0,60 \mathrm{mil} / \mathrm{mm}^{3}$ & $0,82 \mathrm{mil} / \mathrm{mm}^{3}$ & $0,11 \mathrm{mil} / \mathrm{mm}^{3}$ & $1,44 \mathrm{mil} / \mathrm{mm}^{3}$ & $2,02 \mathrm{mil} / \mathrm{mm}^{3}$ & $0,34 \mathrm{mil} / \mathrm{mm}^{3}$ & $1,51 \mathrm{mil} / \mathrm{mm}^{3}$ & $0,11 \mathrm{mil} / \mathrm{mm}^{3}$ & $1,20 \mathrm{mil} / \mathrm{mm}^{3}$ & $2,22 \mathrm{mil} / \mathrm{mm}^{3}$ & $0,40 \mathrm{mil} / \mathrm{mm}^{3}$ & $1,22 \mathrm{mil} / \mathrm{mm}^{3}$ \\
\hline CVID13 & $3,4 \mathrm{mil} / \mathrm{mm}^{3}$ & $0,16 \mathrm{mil} / \mathrm{mm}^{3}$ & $1,43 \mathrm{mil} / \mathrm{mm}^{3}$ & $2,46 \mathrm{mil} / \mathrm{mm}^{3}$ & $0,43 \mathrm{mil} / \mathrm{mm}^{3}$ & $0,11 \mathrm{mil} / \mathrm{mm}^{3}$ & $0,16 \mathrm{mil} / \mathrm{mm}^{3}$ & $1,98 \mathrm{mil} / \mathrm{mm}^{3}$ & $3,11 \mathrm{mil} / \mathrm{mm}^{3}$ & $0,85 \mathrm{mil} / \mathrm{mm}^{3}$ & $0,24 \mathrm{mil} / \mathrm{mm}^{3}$ & $0,16 \mathrm{mil} / \mathrm{mm}^{3}$ & $2,47 \mathrm{mil} / \mathrm{mm}^{3}$ & $2,56 \mathrm{mil} / \mathrm{mm}^{3}$ & $0,86 \mathrm{mil} / \mathrm{mm}^{3}$ & $0,32 \mathrm{mil} / \mathrm{mm}^{3}$ \\
\hline CVID14 & $1,2 \mathrm{mil} / \mathrm{mm}^{3}$ & $0,34 \mathrm{mil} / \mathrm{mm}^{3}$ & $3,00 \mathrm{mil} / \mathrm{mm}^{3}$ & $4,12 \mathrm{mil} / \mathrm{mm}^{3}$ & $0,55 \mathrm{mil} / \mathrm{mm}^{3}$ & $0,06 \mathrm{mil} / \mathrm{mm}^{3}$ & $0,30 \mathrm{mil} / \mathrm{mm}^{3}$ & $3,25 \mathrm{mil} / \mathrm{mm}^{3}$ & $3,66 \mathrm{mil} / \mathrm{mm}^{3}$ & $0,92 \mathrm{mil} / \mathrm{mm} 3$ & $0,24 \mathrm{mil} / \mathrm{mm}^{3}$ & $0,33 \mathrm{mil} / \mathrm{mm}^{3}$ & $2,19 \mathrm{mil} / \mathrm{mm}^{3}$ & $4,23 \mathrm{mil} / \mathrm{mm}^{3}$ & $0,26 \mathrm{mil} / \mathrm{mm}^{3}$ & $0,05 \mathrm{mil} / \mathrm{mm}^{3}$ \\
\hline CVID15 & $2,5 \mathrm{mil} / \mathrm{mm}^{3}$ & $0,13 \mathrm{mil} / \mathrm{mm}^{3}$ & $3,20 \mathrm{mil} / \mathrm{mm}^{3}$ & $1,13 \mathrm{mil} / \mathrm{mm}^{3}$ & $2,03 \mathrm{mil} / \mathrm{mm}^{3}$ & $0,16 \mathrm{mil} / \mathrm{mm}^{3}$ & $0,31 \mathrm{mil} / \mathrm{mm}^{3}$ & $2,32 \mathrm{mil} / \mathrm{mm}^{3}$ & $0,41 \mathrm{mil} / \mathrm{mm}^{3}$ & $3,50 \mathrm{mil} / \mathrm{mm}^{3}$ & $0,09 \mathrm{mil} / \mathrm{mm}^{3}$ & $0,31 \mathrm{mil} / \mathrm{mm}^{3}$ & $2,32 \mathrm{mil} / \mathrm{mm}^{3}$ & $0,41 \mathrm{mil} / \mathrm{mm}^{3}$ & $3,50 \mathrm{mil} / \mathrm{mm}^{3}$ & $0,09 \mathrm{mil} / \mathrm{mm}^{3}$ \\
\hline CVID17 & $3,1 \mathrm{mil} / \mathrm{mm}^{3}$ & $0,30 \mathrm{mil} / \mathrm{mm}^{3}$ & $2,00 \mathrm{mil} / \mathrm{mm}^{3}$ & $0,23 \mathrm{mil} / \mathrm{mm}^{3}$ & $5,31 \mathrm{mil} / \mathrm{mm}^{3}$ & $0,08 \mathrm{mil} / \mathrm{mm}^{3}$ & $0,58 \mathrm{mil} / \mathrm{mm}^{3}$ & $2,87 \mathrm{mil} / \mathrm{mm}^{3}$ & $0,07 \mathrm{mil} / \mathrm{mm}^{3}$ & $4,13 \mathrm{mil} / \mathrm{mm}^{3}$ & $0,10 \mathrm{mil} / \mathrm{mm}^{3}$ & $0,65 \mathrm{mil} / \mathrm{mm}^{3}$ & $2,65 \mathrm{mil} / \mathrm{mm}^{3}$ & $0,13 \mathrm{mil} / \mathrm{mm}^{3}$ & $4,11 \mathrm{mil} / \mathrm{mm}^{3}$ & $0,15 \mathrm{mil} / \mathrm{mm}^{3}$ \\
\hline CVID19 & $2,5 \mathrm{mil} / \mathrm{mm}^{3}$ & $1,32 \mathrm{mil} / \mathrm{mm}^{3}$ & $7,93 \mathrm{mil} / \mathrm{mm}^{3}$ & $5,88 \mathrm{mil} / \mathrm{mm}^{3}$ & $1,40 \mathrm{mil} / \mathrm{mm}^{3}$ & $0,34 \mathrm{mil} / \mathrm{mm}^{3}$ & $1,57 \mathrm{mil} / \mathrm{mm}^{3}$ & $7,39 \mathrm{mil} / \mathrm{mm}^{3}$ & $4,16 \mathrm{mil} / \mathrm{mm}^{3}$ & $1,89 \mathrm{mil} / \mathrm{mm}^{3}$ & $0,54 \mathrm{mil} / \mathrm{mm}^{3}$ & $1,32 \mathrm{mil} / \mathrm{mm}^{3}$ & $7,71 \mathrm{mil} / \mathrm{mm}^{3}$ & $6,76 \mathrm{mil} / \mathrm{mm}^{3}$ & $1,08 \mathrm{mil} / \mathrm{mm}^{3}$ & $0,57 \mathrm{mil} / \mathrm{mm}^{3}$ \\
\hline
\end{tabular}


Anexo 8: Frequência dos Subtipos de Linfócitos B em Indivíduos Controles - Pré Vacinação.

\begin{tabular}{|c|c|c|c|c|c|c|c|c|c|c|c|c|c|c|c|}
\hline \multicolumn{16}{|c|}{ Pré } \\
\hline & \multicolumn{5}{|c|}{ Basal } & \multicolumn{5}{|c|}{ Lisado Viral $20 \mathrm{ng} / \mathrm{mL}$} & \multicolumn{5}{|c|}{ HA $2,5 \mu \mathrm{g} / \mathrm{mL}$} \\
\hline & LB & aive & MZB & SMB & PBL & LB & Naive & MZB & SMB & PBL & LB & Naive & MZB & SMB & PBL \\
\hline cação & $\%$ & $\%$ & $\%$ & $\%$ & $\%$ & $\%$ & $\%$ & $\%$ & $\%$ & $\%$ & $\%$ & $\%$ & $\%$ & $\%$ & $\%$ \\
\hline CTRL01 & $7,43 \%$ & $2,00 \%$ & $9,40 \%$ & $39,70 \%$ & $7,10 \%$ & $7,11 \%$ & $52,20 \%$ & $4,40 \%$ & $11,90 \%$ & $6,69 \%$ & $8,90 \%$ & $58,80 \%$ & $41,70 \%$ & $16,90 \%$ & $10,10 \%$ \\
\hline CTRL02 & $11,70 \%$ & $8,10 \%$ & $4,80 \%$ & $16,20 \%$ & $2,53 \%$ & $8,85 \%$ & $57,70 \%$ & $7,80 \%$ & $17,20 \%$ & $2,87 \%$ & $10,40 \%$ & $61,40 \%$ & $4,06 \%$ & $18,10 \%$ & $2,30 \%$ \\
\hline CTRL03 & $* * *$ & $* * *$ & $* * *$ & $* * *$ & $* * *$ & $10,00 \%$ & $49,10 \%$ & $24,80 \%$ & $17,10 \%$ & $13,10 \%$ & $5,83 \%$ & $67,80 \%$ & $6,28 \%$ & $14,10 \%$ & $3,63 \%$ \\
\hline & $19,50 \%$ & $60 \%$ & $93 \%$ & $20 \%$ & $0,81 \%$ & $21,30 \%$ & $50,30 \%$ & $2,20 \%$ & $30 \%$ & $1,05 \%$ & $25,20 \%$ & $46,70 \%$ & $2,69 \%$ & $1,30 \%$ & $0,81 \%$ \\
\hline $\mathrm{Cl}$ & $60 \%$ & $30 \%$ & $9 \%$ & $7,40 \%$ & $0,93 \%$ & $9,70 \%$ & $44 \%$ & $5,71 \%$ & $50 \%$ & $0,24 \%$ & $3,30 \%$ & $26,40 \%$ & $5,91 \%$ & $62,00 \%$ & $0,30 \%$ \\
\hline & $4,05 \%$ & $42,40 \%$ & $33,40 \%$ & $29,80 \%$ & $* * *$ & $4,13 \%$ & $5,20 \%$ & $17,30 \%$ & $41,10 \%$ & ***** & $48 \%$ & $20 \%$ & $14,00 \%$ & $41,10 \%$ & $* * *$ \\
\hline CTRL07 & $88 \%$ & $9,10 \%$ & $80 \%$ & $5,90 \%$ & $5,82 \%$ & $2,71 \%$ & $7,90 \%$ & $15,70 \%$ & $36,10 \%$ & $7,98 \%$ & $3,25 \%$ & $32,70 \%$ & $26,20 \%$ & $43,80 \%$ & $3,54 \%$ \\
\hline CTRL08 & $3,78 \%$ & $49,30 \%$ & $9 \%$ & $28,70 \%$ & $18,10 \%$ & $8,78 \%$ & $33 \%$ & $11,10 \%$ & $37,30 \%$ & $51,40 \%$ & $11,50 \%$ & $27,70 \%$ & $13,30 \%$ & $32,60 \%$ & $54,80 \%$ \\
\hline $\mathrm{C}$ & $18,10 \%$ & $8,60 \%$ & $20 \%$ & $10,00 \%$ & $60 \%$ & $10,90 \%$ & $6,00 \%$ & $1,60 \%$ & $88 \%$ & $0,26 \%$ & $16,10 \%$ & $15,30 \%$ & $27,50 \%$ & $10,50 \%$ & $1,66 \%$ \\
\hline CTRL10 & $4,69 \%$ & $37,50 \%$ & $45,10 \%$ & $29,70 \%$ & $21,50 \%$ & $3,32 \%$ & $45,10 \%$ & $23,70 \%$ & $53,50 \%$ & $29,30 \%$ & $4,41 \%$ & $43,80 \%$ & $23,00 \%$ & $47,10 \%$ & $35,70 \%$ \\
\hline CTRL11 & $8,19 \%$ & $61,30 \%$ & $17,20 \%$ & $15,10 \%$ & $4,20 \%$ & $5,40 \%$ & $63,50 \%$ & $20,10 \%$ & $13,00 \%$ & $25,50 \%$ & $8,36 \%$ & $74,30 \%$ & $24,40 \%$ & $38,50 \%$ & $40,10 \%$ \\
\hline CTRL12 & $14,70 \%$ & $35,50 \%$ & $17,50 \%$ & $14,90 \%$ & $35,80 \%$ & $12,30 \%$ & $44,30 \%$ & $11,20 \%$ & $11,10 \%$ & $40,40 \%$ & $17,10 \%$ & $65,70 \%$ & $18,30 \%$ & $37,80 \%$ & $61,10 \%$ \\
\hline CTRL13 & $8,62 \%$ & $48,90 \%$ & $5,05 \%$ & $81,70 \%$ & $5,00 \%$ & $6,96 \%$ & $52,90 \%$ & $4,09 \%$ & $85,60 \%$ & $3,28 \%$ & $6,34 \%$ & $50,80 \%$ & $7,72 \%$ & $59,40 \%$ & $4,44 \%$ \\
\hline CTRL14 & $6,12 \%$ & $50,00 \%$ & $12,10 \%$ & $56,00 \%$ & $2,67 \%$ & $4,04 \%$ & $15,80 \%$ & $22,90 \%$ & $23,50 \%$ & $1,12 \%$ & $4,95 \%$ & $46,50 \%$ & $11,50 \%$ & $45,20 \%$ & $1,83 \%$ \\
\hline CTRL15 & $9,03 \%$ & $55,10 \%$ & $3,43 \%$ & $34,90 \%$ & $2,64 \%$ & $8,53 \%$ & $39,80 \%$ & $6,59 \%$ & $42,10 \%$ & $8,11 \%$ & $7,36 \%$ & $64,10 \%$ & $3,48 \%$ & $61,00 \%$ & $1,44 \%$ \\
\hline CTRL16 & $8,39 \%$ & $50,10 \%$ & $5,74 \%$ & $29,20 \%$ & $1,39 \%$ & $6,69 \%$ & $65,30 \%$ & $7,18 \%$ & $60,30 \%$ & $0,96 \%$ & $7,39 \%$ & $37,40 \%$ & $8,14 \%$ & $56,70 \%$ & $1,43 \%$ \\
\hline
\end{tabular}

Frequiências individuais para cada um dos 4 subtipos de LB avaliados no grupo dos pacientes com ICV. Naive: LB naive; MZB: LB de Zona Marginal; SMB: Linfócito B de memória com troca de isotipo; PBL: plasmoblastos.

***: ausência de amostra. 
Anexo 9: Frequência dos Subtipos de Linfócitos B em Pacientes com Imunodeficiência Comum Variável - Pós 1 Mês.

\begin{tabular}{|c|c|c|c|c|c|c|c|c|c|c|c|c|c|c|c|c|}
\hline \multicolumn{17}{|c|}{ Pós 1 Mês } \\
\hline & \multicolumn{6}{|c|}{ Basal } & \multicolumn{5}{|c|}{ Lisado Viral $20 \mathrm{ng} / \mathrm{mL}$} & \multicolumn{5}{|c|}{ HA $2,5 \mu \mathrm{g} / \mathrm{mL}$} \\
\hline & Linfócitos Totais & LB & Naive & MZB & SMB & PBL & LB & Naive & MZB & SMB & PBL & LB & Naive & MZB & SMB & PBL \\
\hline Identificação & $\%$ & $\%$ & $\%$ & $\%$ & $\%$ & $\%$ & $\%$ & $\%$ & $\%$ & $\%$ & $\%$ & $\%$ & $\%$ & $\%$ & $\%$ & $\%$ \\
\hline CVID01 & $43,10 \%$ & $4,56 \%$ & $55,90 \%$ & $18,00 \%$ & $22,70 \%$ & $0,03 \%$ & $3,67 \%$ & $52,10 \%$ & $16,00 \%$ & $26,80 \%$ & $0,02 \%$ & $2,86 \%$ & $48,70 \%$ & $19,10 \%$ & $27,80 \%$ & $0,00 \%$ \\
\hline CVID02 & $* * *$ & $* * *$ & $* * *$ & $* * *$ & $* * *$ & $* * *$ & $* * *$ & $* * *$ & $* * *$ & $* * *$ & $* * *$ & $* * *$ & $* * *$ & $* * *$ & $* * *$ & $* * *$ \\
\hline CVID03 & $29,50 \%$ & $3,89 \%$ & $49,20 \%$ & $35,50 \%$ & $36,90 \%$ & $11,00 \%$ & $4,54 \%$ & $49,70 \%$ & $18,10 \%$ & $54,10 \%$ & $13,40 \%$ & $5,00 \%$ & $56,90 \%$ & $34,60 \%$ & $38,50 \%$ & $7,86 \%$ \\
\hline CVID04 & $30 \%$ & $4,45 \%$ & $59,40 \%$ & $57,10 \%$ & $15,70 \%$ & $11,30 \%$ & $4,32 \%$ & $42,10 \%$ & $72,80 \%$ & $1,35 \%$ & $7,20 \%$ & $2,66 \%$ & $48,60 \%$ & $54,80 \%$ & $1,19 \%$ & $2,81 \%$ \\
\hline CVID05 & $18,90 \%$ & $2,27 \%$ & $60,60 \%$ & $21,20 \%$ & $54,10 \%$ & $11,20 \%$ & $3,45 \%$ & $45,10 \%$ & $11,30 \%$ & $73,10 \%$ & $20,70 \%$ & $4,07 \%$ & $40,00 \%$ & $16,90 \%$ & $70,00 \%$ & $19,20 \%$ \\
\hline CVID06 & $15 \%$ & $5,24 \%$ & $73,80 \%$ & $11,60 \%$ & $18,10 \%$ & $8,56 \%$ & $5,03 \%$ & $73,60 \%$ & $7,84 \%$ & $23,90 \%$ & $8,59 \%$ & $5,53 \%$ & $71,60 \%$ & $9,02 \%$ & $26,10 \%$ & $6,05 \%$ \\
\hline CVID07 & $35,50 \%$ & $0,36 \%$ & $39,50 \%$ & $23,00 \%$ & $42,30 \%$ & $8,52 \%$ & $0,40 \%$ & $37,30 \%$ & $19,20 \%$ & $34,30 \%$ & $22,10 \%$ & $0,30 \%$ & $30,50 \%$ & $32,40 \%$ & $37,00 \%$ & $14,60 \%$ \\
\hline CVID08 & $40 \%$ & $4,30 \%$ & $12,30 \%$ & $32,00 \%$ & $33,00 \%$ & $4,59 \%$ & $3,71 \%$ & $24,30 \%$ & $17,50 \%$ & $43,10 \%$ & $4,92 \%$ & $2,92 \%$ & $12,80 \%$ & $21,70 \%$ & $52,50 \%$ & $6,04 \%$ \\
\hline CVIDl0 & $44,60 \%$ & $12,50 \%$ & $59,80 \%$ & $59,80 \%$ & $5,77 \%$ & $1,96 \%$ & $11,70 \%$ & $51,60 \%$ & $38,90 \%$ & $15,00 \%$ & $8,23 \%$ & $11,60 \%$ & $64,90 \%$ & $40,90 \%$ & $18,60 \%$ & $9,48 \%$ \\
\hline CVIDIl & $* * *$ & $* * *$ & $* * *$ & $* * *$ & $* * *$ & $* * *$ & $* * *$ & $* * *$ & $* * *$ & $* * *$ & $* * *$ & $* * *$ & $* * *$ & $* * *$ & $* * *$ & $* * *$ \\
\hline CVID12 & $39,50 \%$ & $2,84 \%$ & $3,26 \%$ & $3,46 \%$ & $81,30 \%$ & $8,13 \%$ & $2,68 \%$ & $2,36 \%$ & $1,85 \%$ & $86,80 \%$ & $2,84 \%$ & $1,72 \%$ & $3,08 \%$ & $2,62 \%$ & $88,80 \%$ & $3,93 \%$ \\
\hline CVID13 & $* * *$ & $* * *$ & $* * *$ & $* * *$ & $* * *$ & $* * *$ & $* * *$ & $* * *$ & $* * *$ & $* * *$ & $* * *$ & $* * *$ & $* * *$ & $* * *$ & $* * *$ & $* * *$ \\
\hline CVID14 & $26,20 \%$ & $1,95 \%$ & $7,19 \%$ & $8,10 \%$ & $78,90 \%$ & $6,95 \%$ & $2,11 \%$ & $4,01 \%$ & $5,61 \%$ & $82,50 \%$ & $2,35 \%$ & $1,44 \%$ & $5,22 \%$ & $3,75 \%$ & $85,60 \%$ & $1,81 \%$ \\
\hline CVID15 & $43,60 \%$ & $3,30 \%$ & $74,90 \%$ & $40,90 \%$ & $10,70 \%$ & $42,40 \%$ & $1,47 \%$ & $76,60 \%$ & $46,90 \%$ & $12,90 \%$ & $37,50 \%$ & $3,19 \%$ & $54,70 \%$ & $30,00 \%$ & $16,40 \%$ & $52,00 \%$ \\
\hline CVID17 & $36,30 \%$ & $7,21 \%$ & $52,50 \%$ & $0,26 \%$ & $24,00 \%$ & $22,40 \%$ & $5,50 \%$ & $49,00 \%$ & $0,13 \%$ & $46,10 \%$ & $15,70 \%$ & $4,78 \%$ & $40,40 \%$ & $0,24 \%$ & $41,60 \%$ & $12,20 \%$ \\
\hline CVID19 & $20,40 \%$ & $13,90 \%$ & $71,30 \%$ & $39,00 \%$ & $19,30 \%$ & $47,80 \%$ & $12,40 \%$ & $53,80 \%$ & $18,60 \%$ & $34,70 \%$ & $54,10 \%$ & $17,50 \%$ & $56,00 \%$ & $18,60 \%$ & $35,30 \%$ & $60,30 \%$ \\
\hline
\end{tabular}

Freqüências individuais para cada um dos 4 subtipos de LB avaliados no grupo dos pacientes com ICV. Naive: LB naive; MZB: LB de Zona Marginal; SMB: Linfócito B de memória com troca de isotipo; PBL: plasmoblastos.

***: ausência de amostra. 
Anexo 10: Valores Absolutos dos Subtipos de Linfócitos B em Pacientes com Imunodeficiência Comum Variável - Pós 1 Mês.

\begin{tabular}{|c|c|c|c|c|c|c|c|c|c|c|c|c|c|c|c|c|}
\hline \multicolumn{17}{|c|}{ Pós 1 Mês } \\
\hline & \multicolumn{6}{|c|}{ Basal } & \multicolumn{5}{|c|}{ Lisado Viral $20 \mathrm{ng} / \mathrm{mL}$} & \multicolumn{5}{|c|}{ HA $2,5 \mu \mathrm{g} / \mathrm{mL}$} \\
\hline & Linfócitos Totais & LB & Naive & MZB & SMB & $\begin{array}{l}\text { PBL } \\
\end{array}$ & LB & Naive & MZB & $\overline{\text { SMB }}$ & PBL & LB & Naive & MZB & SMB & PBL \\
\hline Identificação & Abs. & Abs. & Abs. & Abs. & Abs. & Abs. & Abs. & Abs. & Abs. & Abs. & Abs. & Abs. & Abs. & Abs. & Abs. & Abs. \\
\hline CVID01 & $2,1 \mathrm{mil} / \mathrm{mm}^{3}$ & $0,22 \mathrm{mil} / \mathrm{mm}^{3}$ & $2,72 \mathrm{mil} / \mathrm{mm}^{3}$ & $0,88 \mathrm{mil} / \mathrm{mm}^{3}$ & $1,11 \mathrm{mil} / \mathrm{mm}^{3}$ & $0 \mathrm{mil} / \mathrm{mm}^{3}$ & $0,18 \mathrm{mil} / \mathrm{mm}^{3}$ & $2,54 \mathrm{mil} / \mathrm{mm}^{3}$ & $0,78 \mathrm{mil} / \mathrm{mm}^{3}$ & $1,31 \mathrm{mil} / \mathrm{mm}^{3}$ & $0 \mathrm{mil} / \mathrm{mm}^{3}$ & $14 \mathrm{mil} / \mathrm{mm}^{3}$ & $2,37 \mathrm{mil} / \mathrm{mm}^{3}$ & $0,93 \mathrm{mil} / \mathrm{mm}^{3}$ & $1,35 \mathrm{mil} / \mathrm{mm}^{3}$ & $0 \mathrm{mil} / \mathrm{mm}^{3}$ \\
\hline CVID02 & **** & **** & $* * *$ & $* * *$ & $* * *$ & **** & **** & **** & **** & **** & **** & **** & **** & **** & **** & **** \\
\hline CVID03 & $1,7 \mathrm{mil} / \mathrm{mm}^{3}$ & $0,22 \mathrm{mil} / \mathrm{mm}^{3}$ & $2,84 \mathrm{mil} / \mathrm{mm}^{3}$ & $2,05 \mathrm{mil} / \mathrm{mm}^{3}$ & $2,13 \mathrm{mil} / \mathrm{mm}^{3}$ & $0,63 \mathrm{mil} / \mathrm{mm}^{3}$ & $0,26 \mathrm{mil} / \mathrm{mm}^{3}$ & $2,86 \mathrm{mil} / \mathrm{mm}^{3}$ & $1,04 \mathrm{mil} / \mathrm{mm}^{3}$ & $3,12 \mathrm{mil} / \mathrm{mm}^{3}$ & $0,77 \mathrm{mil} / \mathrm{mm}^{3}$ & $0,29 \mathrm{mil} / \mathrm{mm}^{3}$ & $3,28 \mathrm{mil} / \mathrm{mm}^{3}$ & $1,99 \mathrm{mil} / \mathrm{mm}^{3}$ & $2,22 \mathrm{mil} / \mathrm{mm}^{3}$ & $0,45 \mathrm{mil} / \mathrm{mm}^{3}$ \\
\hline CVID04 & $3,4 \mathrm{mil} / \mathrm{mm}^{3}$ & $0,50 \mathrm{mil} / \mathrm{mm}^{3}$ & $6,73 \mathrm{mil} / \mathrm{mm}^{3}$ & $6,47 \mathrm{mil} / \mathrm{mm}^{3}$ & $1,78 \mathrm{mil} / \mathrm{mm}^{3}$ & $1,28 \mathrm{mil} / \mathrm{mm}^{3}$ & $0,49 \mathrm{mil} / \mathrm{mm}^{3}$ & $4,77 \mathrm{mil} / \mathrm{mm}^{3}$ & $8,25 \mathrm{mil} / \mathrm{mm}^{3}$ & $0,15 \mathrm{mil} / \mathrm{mm}^{3}$ & $0,82 \mathrm{mil} / \mathrm{mm}^{3}$ & $0,30 \mathrm{mil} / \mathrm{mm}^{3}$ & $5,51 \mathrm{mil} / \mathrm{mm}^{3}$ & $6,21 \mathrm{mil} / \mathrm{mm}^{3}$ & $0,13 \mathrm{mil} / \mathrm{mm}^{3}$ & $0,32 \mathrm{mil} / \mathrm{mm}^{3}$ \\
\hline CVID05 & $1,9 \mathrm{mil} / \mathrm{mm}^{3}$ & $0,23 \mathrm{mil}^{2} \mathrm{~mm}^{3}$ & $6,09 \mathrm{mil} / \mathrm{mm}^{3}$ & $2,13 \mathrm{mil} / \mathrm{mm}^{3}$ & $5,44 \mathrm{mil} / \mathrm{mm}^{3}$ & $1,13 \mathrm{mil} / \mathrm{mm}^{3}$ & $0,35 \mathrm{mil}^{2} \mathrm{~mm}^{3}$ & $4,53 \mathrm{mil} / \mathrm{mm}^{3}$ & $1,14 \mathrm{mil} / \mathrm{mm}^{3}$ & $7,35 \mathrm{mil} / \mathrm{mm}^{3}$ & $2,08 \mathrm{mil} / \mathrm{mm}^{3}$ & $0,41 \mathrm{mil} / \mathrm{mm}^{3}$ & $4,02 \mathrm{mil} / \mathrm{mm}^{3}$ & $1,70 \mathrm{mil} / \mathrm{mm}^{3}$ & $7,04 \mathrm{mil} / \mathrm{mm}^{3}$ & $1,93 \mathrm{mil} / \mathrm{mm} 3$ \\
\hline CVID06 & $1,2 \mathrm{mil} / \mathrm{mm}^{3}$ & $0,42 \mathrm{mil} / \mathrm{mm}^{3}$ & $5,90 \mathrm{mil} / \mathrm{mm}^{3}$ & $0,93 \mathrm{mil} / \mathrm{mm}^{3}$ & $1,45 \mathrm{mil} / \mathrm{mm}^{3}$ & $0,68 \mathrm{mil} / \mathrm{mm}^{3}$ & $0,40 \mathrm{mil} / \mathrm{mm}^{3}$ & $5,89 \mathrm{mil} / \mathrm{mm}^{3}$ & $0,63 \mathrm{mil} / \mathrm{mm}^{3}$ & $1,91 \mathrm{mil} / \mathrm{mm}^{3}$ & $0,69 \mathrm{mil} / \mathrm{mm}^{3}$ & $0,44 \mathrm{mil} / \mathrm{mm}^{3}$ & $5,73 \mathrm{mil} / \mathrm{mm}^{3}$ & $0,72 \mathrm{mil} / \mathrm{mm}^{3}$ & $2,09 \mathrm{mil} / \mathrm{mm}^{3}$ & $0,48 \mathrm{mil} / \mathrm{mm} 3$ \\
\hline CVID07 & $1,8 \mathrm{mil} / \mathrm{mm}^{3}$ & $0,02 \mathrm{mil} / \mathrm{mm}^{3}$ & $2,00 \mathrm{mil} / \mathrm{mm}^{3}$ & $1,17 \mathrm{mil} / \mathrm{mm}^{3}$ & $2,14 \mathrm{mil} / \mathrm{mm}^{3}$ & $0,43 \mathrm{mil} / \mathrm{mm}^{3}$ & $0,02 \mathrm{mil} / \mathrm{mm}^{3}$ & $1,89 \mathrm{mil} / \mathrm{mm}^{3}$ & $0,97 \mathrm{mil} / \mathrm{mm}^{3}$ & $1,74 \mathrm{mil} / \mathrm{mm}^{3}$ & $1,12 \mathrm{mil} / \mathrm{mm}^{3}$ & $0,02 \mathrm{mil} / \mathrm{mm}^{3}$ & $1,55 \mathrm{mil} / \mathrm{mm}^{3}$ & $1,64 \mathrm{mil} / \mathrm{mm}^{3}$ & $1,88 \mathrm{mil} / \mathrm{mm}^{3}$ & $0,74 \mathrm{mil} / \mathrm{mm}^{3}$ \\
\hline CVID08 & $1,9 \mathrm{mil} / \mathrm{mm}^{3}$ & $0,20 \mathrm{mil} / \mathrm{mm}^{3}$ & $0,58 \mathrm{mil} / \mathrm{mm}^{3}$ & $1,52 \mathrm{mil} / \mathrm{mm}^{3}$ & $1,57 \mathrm{mil} / \mathrm{mm}^{3}$ & $0,22 \mathrm{mil} / \mathrm{mm}^{3}$ & $0,18 \mathrm{mil} / \mathrm{mm}^{3}$ & $1,15 \mathrm{mil} / \mathrm{mm}^{3}$ & $0,83 \mathrm{mil} / \mathrm{mm}^{3}$ & $2,05 \mathrm{mil} / \mathrm{mm}^{3}$ & $0,23 \mathrm{mil} / \mathrm{mm}^{3}$ & $0,14 \mathrm{mil} / \mathrm{mm}^{3}$ & $0,61 \mathrm{mil} / \mathrm{mm}^{3}$ & $1,03 \mathrm{mil} / \mathrm{mm}^{3}$ & $2,49 \mathrm{mil} / \mathrm{mm}^{3}$ & $0,29 \mathrm{mil} / \mathrm{mm}^{3}$ \\
\hline CVID10 & $2,5 \mathrm{mil} / \mathrm{mm}^{3}$ & $0,70 \mathrm{mil} / \mathrm{mm}^{3}$ & $3,35 \mathrm{mil} / \mathrm{mm}^{3}$ & $3,35 \mathrm{mil} / \mathrm{mm}^{3}$ & $0,32 \mathrm{mil} / \mathrm{mm}^{3}$ & $0,11 \mathrm{mil} / \mathrm{mm}^{3}$ & $0,66 \mathrm{mil} / \mathrm{mm}^{3}$ & $2,89 \mathrm{mil} / \mathrm{mm}^{3}$ & $2,18 \mathrm{mil} / \mathrm{mm}^{3}$ & $0,84 \mathrm{mil} / \mathrm{mm}^{3}$ & $0,46 \mathrm{mil} / \mathrm{mm}^{3}$ & $0,65 \mathrm{mil} / \mathrm{mm}^{3}$ & $3,64 \mathrm{mil} / \mathrm{mm}^{3}$ & $2,29 \mathrm{mil} / \mathrm{mm}^{3}$ & $1,04 \mathrm{mil} / \mathrm{mm}^{3}$ & 0, \\
\hline CVID11 & $* * *$ & $* * *$ & $* * *$ & **** & $* * *$ & $* * *$ & $* * *$ & $* * *$ & $* * *$ & $* * *$ & $* * *$ & $* * *$ & $* * *$ & $* * *$ & $* * *$ & $* * *$ \\
\hline CVID12 & $1,7 \mathrm{mil} / \mathrm{mm}^{3}$ & $0,12 \mathrm{mil} / \mathrm{mm}^{3}$ & $0,14 \mathrm{mil} / \mathrm{mm}^{3}$ & $15 \mathrm{mil} / \mathrm{mm}^{3}$ & $3,50 \mathrm{mil} / \mathrm{mm}^{3}$ & $35 \mathrm{mil}^{2} \mathrm{~mm}^{3}$ & $0,12 \mathrm{mil} / \mathrm{mm}^{3}$ & $0,10 \mathrm{mil} / \mathrm{mm}^{3}$ & $0,08 \mathrm{mil} / \mathrm{mm}^{3}$ & $3,74 \mathrm{mil} / \mathrm{mm}^{3}$ & $0,12 \mathrm{mil} / \mathrm{mm}^{3}$ & $0,07 \mathrm{mil} / \mathrm{mm}^{3}$ & $0,13 \mathrm{mil} / \mathrm{mm}^{3}$ & $0,11 \mathrm{mil} / \mathrm{mm}^{3}$ & $3,82 \mathrm{mil} / \mathrm{mm}^{3}$ & $0,17 \mathrm{mil} / \mathrm{mm}^{3}$ \\
\hline CVID13 & $* * *$ & $* * *$ & $* * *$ & $* * *$ & $* * *$ & $* * *$ & $* * *$ & $* * *$ & $* * *$ & $* * *$ & $* * *$ & $* * *$ & $* * *$ & $* * *$ & $* * *$ & $* * *$ \\
\hline CVID14 & $1,8 \mathrm{mil} / \mathrm{mm}^{3}$ & $0,13 \mathrm{mil} / \mathrm{mm}^{3}$ & $0,49 \mathrm{mil} / \mathrm{mm}^{3}$ & $0,56 \mathrm{mil} / \mathrm{mm}^{3}$ & $5,42 \mathrm{mil} / \mathrm{mm}^{3}$ & $0,48 \mathrm{mil} / \mathrm{mm}^{3}$ & $0,14 \mathrm{mil} / \mathrm{mm}^{3}$ & $0,28 \mathrm{mil} / \mathrm{mm}^{3}$ & $0,39 \mathrm{mil} / \mathrm{mm}^{3}$ & $5,67 \mathrm{mil} / \mathrm{mm}^{3}$ & $0,16 \mathrm{mil} / \mathrm{mm}^{3}$ & $0,10 \mathrm{mil} / \mathrm{mm}^{3}$ & $0,36 \mathrm{mil} / \mathrm{mm}^{3}$ & $0,26 \mathrm{mil} / \mathrm{mm}^{3}$ & $5,88 \mathrm{mil} / \mathrm{mm} 3$ & $0,12 \mathrm{mil} / \mathrm{mm}^{3}$ \\
\hline CVID15 & $2,4 \mathrm{mil} / \mathrm{mm}^{3}$ & $0,18 \mathrm{mil} / \mathrm{mm}^{3}$ & $4,12 \mathrm{mil} / \mathrm{mm}^{3}$ & $2,25 \mathrm{mil} / \mathrm{mm}^{3}$ & $0,59 \mathrm{mil} / \mathrm{mm}^{3}$ & $2,33 \mathrm{mil} / \mathrm{mm}^{3}$ & $0,08 \mathrm{mil}^{2} \mathrm{~mm}^{3}$ & $4,22 \mathrm{mil} / \mathrm{mm}^{3}$ & $2,58 \mathrm{mil} / \mathrm{mm}^{3}$ & $0,71 \mathrm{mil} / \mathrm{mm}^{3}$ & $2,06 \mathrm{mil} / \mathrm{mm}^{3}$ & $0,18 \mathrm{mil} / \mathrm{mm}^{3}$ & $3,01 \mathrm{mil} / \mathrm{mm}^{3}$ & $1,65 \mathrm{mil} / \mathrm{mm}^{3}$ & $0,90 \mathrm{mil} / \mathrm{mm}^{3}$ & $2,86 \mathrm{mil} / \mathrm{mm}^{3}$ \\
\hline CVID17 & $3,8 \mathrm{mil} / \mathrm{mm}^{3}$ & $0,75 \mathrm{mil} / \mathrm{mm}^{3}$ & $5,50 \mathrm{mil} / \mathrm{mm}^{3}$ & $0,03 \mathrm{mil} / \mathrm{mm}^{3}$ & $2,51 \mathrm{mil} / \mathrm{mm}^{3}$ & $2,34 \mathrm{mil} / \mathrm{mm}^{3}$ & $0,58 \mathrm{mil} / \mathrm{mm}^{3}$ & $5,13 \mathrm{mil} / \mathrm{mm}^{3}$ & $0,01 \mathrm{mil} / \mathrm{mm}^{3}$ & $4,83 \mathrm{mil} / \mathrm{mm}^{3}$ & $1,64 \mathrm{mil} / \mathrm{mm}^{3}$ & $0,50 \mathrm{mil} / \mathrm{mm}^{3}$ & $4,23 \mathrm{mil} / \mathrm{mm}^{3}$ & $0,03 \mathrm{mil} / \mathrm{mm}^{3}$ & $4,35 \mathrm{mil} / \mathrm{mm}^{3}$ & $1,28 \mathrm{mil} / \mathrm{mm}^{3}$ \\
\hline CVID19 & $2,6 \mathrm{mil} / \mathrm{mm}^{3}$ & $1,77 \mathrm{mil} / \mathrm{mm}^{3}$ & $9,09 \mathrm{mil} / \mathrm{mm}^{3}$ & $4,97 \mathrm{mil} / \mathrm{mm}^{3}$ & $2,46 \mathrm{mil} / \mathrm{mm}^{3}$ & $6,09 \mathrm{mil} / \mathrm{mm}^{3}$ & $1,58 \mathrm{mil} / \mathrm{mm}^{3}$ & $6,86 \mathrm{mil} / \mathrm{mm}^{3}$ & $2,37 \mathrm{mil} / \mathrm{mm}^{3}$ & $4,42 \mathrm{mil} / \mathrm{mm}^{3}$ & $6,90 \mathrm{mil} / \mathrm{mm}^{3}$ & $2,23 \mathrm{mil} / \mathrm{mm}^{3}$ & $7,14 \mathrm{mil} / \mathrm{mm}^{3}$ & $2,37 \mathrm{mil} / \mathrm{mm}^{3}$ & $4,50 \mathrm{mil} / \mathrm{mm}^{3}$ & $7,69 \mathrm{mil} / \mathrm{mm}^{3}$ \\
\hline
\end{tabular}


Anexo 11: Frequência dos Subtipos de Linfócitos B em Indivíduos Controles - Pós 1 Mês.

\begin{tabular}{|c|c|c|c|c|c|c|c|c|c|c|c|c|c|c|c|}
\hline \multicolumn{16}{|c|}{ Pós 1 Mês } \\
\hline & \multicolumn{5}{|c|}{ Basal } & \multicolumn{5}{|c|}{ Lisado Viral $20 \mathrm{ng} / \mathrm{mL}$} & \multicolumn{5}{|c|}{ HA $2,5 \mu \mathrm{g} / \mathrm{mL}$} \\
\hline & LB & Naive & MZB & SMB & PBL & LB & Naive & MZB & SMB & PBL & LB & Naive & MZB & SMB & PBL \\
\hline Identificação & $\%$ & $\%$ & $\%$ & $\%$ & $\%$ & $\%$ & $\%$ & $\%$ & $\%$ & $\%$ & $\%$ & $\%$ & $\%$ & $\%$ & $\%$ \\
\hline CTRL01 & $8,80 \%$ & $30,60 \%$ & $3,73 \%$ & $21,40 \%$ & $1,04 \%$ & $12,70 \%$ & $34,30 \%$ & $1,67 \%$ & $36,40 \%$ & $0,78 \%$ & $10,80 \%$ & $28,50 \%$ & $1,57 \%$ & $60,30 \%$ & $3,49 \%$ \\
\hline CTRL02 & *** & $* * *$ & $* * *$ & $* * *$ & $* * *$ & $* * *$ & $* * *$ & $* * *$ & $* * *$ & $* * *$ & $* * *$ & $* * *$ & $* * *$ & $* * *$ & $* * *$ \\
\hline CTRL03 & $4,73 \%$ & $44,60 \%$ & $27,40 \%$ & $29,90 \%$ & $9,34 \%$ & $5,28 \%$ & $41,80 \%$ & $29,20 \%$ & $42,50 \%$ & $6,58 \%$ & $* * *$ & $* * *$ & $* * *$ & $* * *$ & $* * *$ \\
\hline CTRL04 & $4,13 \%$ & $49,20 \%$ & $31,00 \%$ & $18,80 \%$ & $3,69 \%$ & $4,16 \%$ & $47,00 \%$ & $35,70 \%$ & $18,30 \%$ & $4,69 \%$ & $3,62 \%$ & $50,50 \%$ & $45,00 \%$ & $11,90 \%$ & $6,93 \%$ \\
\hline CTRL05 & $10,00 \%$ & $27,60 \%$ & $7,69 \%$ & $46,40 \%$ & $47,10 \%$ & $11,30 \%$ & $31,10 \%$ & $20,00 \%$ & $40,90 \%$ & $40,00 \%$ & $11,00 \%$ & $24,80 \%$ & $11,60 \%$ & $50,00 \%$ & $37,10 \%$ \\
\hline CTRL06 & $3,54 \%$ & $39,50 \%$ & $22,00 \%$ & $32,40 \%$ & $6,94 \%$ & $3,10 \%$ & $10 \%$ & $15,30 \%$ & $37,00 \%$ & $5,15 \%$ & $3,95 \%$ & $44,00 \%$ & $15,00 \%$ & $32,80 \%$ & $4,37 \%$ \\
\hline CTRL07 & $11,00 \%$ & $60,90 \%$ & $39,80 \%$ & $34,30 \%$ & $20,20 \%$ & $9,42 \%$ & $51,80 \%$ & $36,90 \%$ & $32,80 \%$ & $17,50 \%$ & $11,00 \%$ & $37,00 \%$ & $24,40 \%$ & $31,60 \%$ & $27,70 \%$ \\
\hline CTRL08 & $18,90 \%$ & $51,40 \%$ & $18,60 \%$ & $30,30 \%$ & $5,43 \%$ & $8,53 \%$ & $54,10 \%$ & $31,60 \%$ & $27,70 \%$ & $5,81 \%$ & $16,50 \%$ & $51,90 \%$ & $25,60 \%$ & $28,70 \%$ & $5,90 \%$ \\
\hline CTRL09 & $27,70 \%$ & $48,60 \%$ & $1,49 \%$ & $36,80 \%$ & $31,60 \%$ & $24,40 \%$ & $37,60 \%$ & $1,37 \%$ & $50,50 \%$ & $31,20 \%$ & $24,40 \%$ & $38,40 \%$ & $2,79 \%$ & $52,00 \%$ & $35,10 \%$ \\
\hline CTRL10 & $4,19 \%$ & $24,60 \%$ & $14,80 \%$ & $42,40 \%$ & $3,55 \%$ & $2,69 \%$ & $15,00 \%$ & $10,40 \%$ & $53,10 \%$ & $11,10 \%$ & $2,65 \%$ & $23,50 \%$ & $9,55 \%$ & $57,70 \%$ & $6,52 \%$ \\
\hline 11 & $3 \%$ & $40 \%$ & $9,90 \%$ & $73,30 \%$ & $15,30 \%$ & $2,62 \%$ & $8,85 \%$ & $14,90 \%$ & $67,40 \%$ & $16,40 \%$ & $2,38 \%$ & $8,19 \%$ & $9,74 \%$ & $73,30 \%$ & $17,70 \%$ \\
\hline CTRL12 & $16,00 \%$ & $53,10 \%$ & $12,40 \%$ & $73,20 \%$ & $11,30 \%$ & $12,20 \%$ & $41,20 \%$ & $4,51 \%$ & $78,70 \%$ & $10,20 \%$ & $13,20 \%$ & $50,40 \%$ & $8,49 \%$ & $75,60 \%$ & $11,20 \%$ \\
\hline CTRL13 & $23,20 \%$ & $54,50 \%$ & $1,17 \%$ & $44,60 \%$ & $30,50 \%$ & $19,90 \%$ & $61,50 \%$ & $0,82 \%$ & $47,10 \%$ & $34,80 \%$ & $19,40 \%$ & $33,90 \%$ & $2,47 \%$ & $43,40 \%$ & $40,90 \%$ \\
\hline CTRL14 & $18,10 \%$ & $29,10 \%$ & $1,64 \%$ & $50,60 \%$ & $15,40 \%$ & $8,11 \%$ & $33,10 \%$ & $2,15 \%$ & $49,70 \%$ & $15,90 \%$ & $16,60 \%$ & $25,80 \%$ & $2,44 \%$ & $56,30 \%$ & $42,60 \%$ \\
\hline CTRL15 & $* * *$ & $* * *$ & $* * *$ & $* * *$ & $* * *$ & $* * *$ & $* * *$ & $* * *$ & $* * *$ & $* * *$ & $* * *$ & $* * *$ & $* * *$ & $* * *$ & $* * *$ \\
\hline CTRL16 & $9,64 \%$ & $38,10 \%$ & $1,43 \%$ & $8,50 \%$ & $27,30 \%$ & $11,60 \%$ & $19,40 \%$ & $2,11 \%$ & $54,80 \%$ & $22,30 \%$ & $12,00 \%$ & $27,90 \%$ & $1,54 \%$ & $35,40 \%$ & $29,20 \%$ \\
\hline
\end{tabular}

Freqüências individuais para cada um dos 4 subtipos de LB avaliados no grupo dos pacientes com ICV. Naive: LB naive; MZB: LB de Zona Marginal; SMB: Linfócito B de memória com troca de isotipo; PBL: plasmoblastos.

***: ausência de amostra. 
Anexo 12: Frequência dos Subtipos de Linfócitos B em Pacientes com Imunodeficiência Comum Variável - Pós 3 Meses.

\begin{tabular}{|c|c|c|c|c|c|c|c|c|c|c|c|c|c|c|c|c|}
\hline \multicolumn{17}{|c|}{ Pós 3 Meses } \\
\hline & \multicolumn{6}{|c|}{ Basal } & \multicolumn{5}{|c|}{ Lisado Viral $20 \mathrm{ng} / \mathrm{mL}$} & \multicolumn{5}{|c|}{ HA 2,5 $\mu \mathrm{g} / \mathrm{mL}$} \\
\hline & \begin{tabular}{|l} 
Linfócitos Totais \\
\end{tabular} & LB & Naive & MZB & MB & PBL & LB & Naive & MZB & SMB & PBL & LB & Naive & MZB & SMB & PBL \\
\hline Identificação & $\%$ & $\%$ & $\%$ & $\%$ & $\%$ & $\%$ & $\%$ & $\%$ & $\%$ & $\%$ & $\%$ & $\%$ & $\%$ & $\%$ & $\%$ & $\%$ \\
\hline CVID01 & $10 \%$ & $3,38 \%$ & $00 \%$ & $40 \%$ & $7,90 \%$ & $3,35 \%$ & $3,08 \%$ &, $00 \%$ & $31,70 \%$ & $8,00 \%$ & $2,31 \%$ & $3,15 \%$ & $4,60 \%$ & $61,50 \%$ & $12,60 \%$ & $1,45 \%$ \\
\hline CV & $*$ & $1,13 \%$ & $5,60 \%$ & $38,20 \%$ & $22,10 \%$ & $12,10 \%$ & $3,07 \%$ & $52,80 \%$ & $66,30 \%$ & $16,30 \%$ & $16,30 \%$ & $1,02 \%$ & $60,90 \%$ & $54,80 \%$ & $5,24 \%$ & $6,85 \%$ \\
\hline $\mathrm{Cr}$ & $60 \%$ & $0 \%$ & $\%$ & $\%$ & $\%$ & $\%$ & 0 & $\%$ & $\%$ & $74 \%$ & $\%$ & $\%$ & $\%$ & $\%$ & $0,00 \%$ & $\%$ \\
\hline & & $12 \%$ & $30 \%$ & $30 \%$ & $1,09 \%$ & $34 \%$ & $2,35 \%$ & $10 \%$ & $79,30 \%$ & $0,44 \%$ & $52 \%$ & $00 \%$ & $4,20 \%$ & $93,80 \%$ & $0,33 \%$ & $0,08 \%$ \\
\hline & *** & $2,11 \%$ & $45,30 \%$ & $65,30 \%$ & $4,74 \%$ & $8,27 \%$ & $2,09 \%$ & $45,10 \%$ & $70,10 \%$ & $8,01 \%$ & $6,71 \%$ & $1,67 \%$ & $46,40 \%$ & $58,60 \%$ & $13,10 \%$ & $11,20 \%$ \\
\hline CVID06 & $80 \%$ & $5,01 \%$ & $81,70 \%$ & $10,50 \%$ & $16,40 \%$ & $16,10 \%$ & $6,93 \%$ & $81,00 \%$ & $12,70 \%$ & $15,70 \%$ & $12,90 \%$ & $5,97 \%$ & $78,20 \%$ & $12,30 \%$ & $18,70 \%$ & $16,30 \%$ \\
\hline $\mathrm{CI}$ & $20 \%$ & $5,55 \%$ & $99 \%$ & $17 \%$ & $24 \%$ & $4,91 \%$ & $4,01 \%$ & $15,40 \%$ & $4,17 \%$ & $7,80 \%$ & $3,56 \%$ & $5,46 \%$ & $3,80 \%$ & $1,67 \%$ & $5,88 \%$ & $1,16 \%$ \\
\hline D08 & $40 \%$ & $6,61 \%$ & $76,40 \%$ & $84,80 \%$ & $1,68 \%$ & $0,22 \%$ & $4,98 \%$ & $46,30 \%$ & $84,50 \%$ & $2,54 \%$ & $1,37 \%$ & $4,87 \%$ & $58,90 \%$ & $85,20 \%$ & $1,77 \%$ & $1,77 \%$ \\
\hline & $40,80 \%$ & $24,00 \%$ & $3,79 \%$ & $8,36 \%$ & $27,70 \%$ & $64,90 \%$ & $7,13 \%$ & $27,00 \%$ & $7,64 \%$ & $14,40 \%$ & $71,40 \%$ & $6,02 \%$ & $35,60 \%$ & $11,20 \%$ & $10,00 \%$ & $71,90 \%$ \\
\hline $\mathrm{CI}$ & **** & $* * *$ & **** & **** & **** & $* * *$ & $* * *$ & $* * *$ & $* * *$ & $* * *$ & $* * *$ & $* * *$ & $* * *$ & $* * *$ & $* * *$ & $* * *$ \\
\hline CVID12 & $* * *$ & $* * *$ & $* * *$ & $* * *$ & $* * *$ & $* * *$ & $* * *$ & **** & $* * *$ & $* * *$ & **** & $* * *$ & $* * *$ & **** & $* * *$ & **** \\
\hline $\mathrm{Cl}$ & $55,60 \%$ & $2,07 \%$ & $37,20 \%$ & $10,90 \%$ & $61,00 \%$ & $18,30 \%$ & $3,07 \%$ & $26,50 \%$ & $2,38 \%$ & $84,30 \%$ & $1,10 \%$ & $1,66 \%$ & $40,40 \%$ & $15,10 \%$ & $57,00 \%$ & $15,40 \%$ \\
\hline & 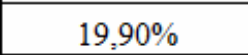 & & & & & 80 & & & $99,60 \%$ & $37 \%$ & $81 \%$ & $54 \%$ & $47,20 \%$ & $5,50 \%$ & $13,60 \%$ & $5,94 \%$ \\
\hline & $* * *$ & $3,35 \%$ & $45,00 \%$ & $45,80 \%$ & $31,30 \%$ & $0,00 \%$ & $0,86 \%$ & $47,30 \%$ & $34,60 \%$ & $22,40 \%$ & $3,41 \%$ & $1,84 \%$ & $27,70 \%$ & $26,20 \%$ & $30,80 \%$ & $1,10 \%$ \\
\hline & **** & **** & **** & $* * *$ & **** & **** & $* * *$ & **** & **** & **** & **** & **** & **** & $* * *$ & **** & **** \\
\hline CVID19 & $* * *$ & $13,90 \%$ & $71,30 \%$ & $39,00 \%$ & $19,30 \%$ & $47,80 \%$ & $12,40 \%$ & $53,80 \%$ & $18,60 \%$ & $34,70 \%$ & $54,10 \%$ & $17,50 \%$ & $56,00 \%$ & $18,60 \%$ & $35,30 \%$ & $60,30 \%$ \\
\hline
\end{tabular}

Frequiências individuais para cada um dos 4 subtipos de LB avaliados no grupo dos pacientes com ICV. Naive: LB naive; MZB: LB de Zona Marginal; SMB: Linfócito B de memória com troca de isotipo; PBL: plasmoblastos.

***: ausência de amostra. 
Anexo 13: Valores Absolutos dos Subtipos de Linfócitos B em Pacientes com Imunodeficiência Comum Variável - Pós 3 Meses.

\begin{tabular}{|c|c|c|c|c|c|c|c|c|c|c|c|c|c|c|c|c|}
\hline \multicolumn{17}{|c|}{ Pós 3 Meses } \\
\hline & \multicolumn{6}{|c|}{ Basal } & \multicolumn{5}{|c|}{ Lisado Viral $20 \mathrm{ng} / \mathrm{mL}$} & \multicolumn{5}{|c|}{ HA $2,5 \mu \mathrm{g} / \mathrm{mL}$} \\
\hline & Linfócitos Totais & LB & Naive & MZB & SMB & PBL & LB & Naive & MZB & SMB & PBL & LB & Naive & MZB & SMB & PBL \\
\hline Identificação & Abs. & Abs. & Abs. & Abs. & Abs. & Abs. & Abs. & Abs. & Abs. & Abs. & Abs. & Abs. & Abs. & Abs. & Abs. & Abs. \\
\hline CVID01 & $2,7 \mathrm{mil} / \mathrm{mm}^{3}$ & $0,22 \mathrm{mil} / \mathrm{mm}^{3}$ & $4,73 \mathrm{mil} / \mathrm{mm}^{3}$ & $3,64 \mathrm{mil} / \mathrm{mm}^{3}$ & $1,18 \mathrm{mil} / \mathrm{mm}^{3}$ & $0,22 \mathrm{mil} / \mathrm{mm}^{3}$ & $0,20 \mathrm{mil} / \mathrm{mm}^{3}$ & $3,35 \mathrm{mil} / \mathrm{mm}^{3}$ & $2,08 \mathrm{mil} / \mathrm{mm}^{3}$ & $2,50 \mathrm{mil} / \mathrm{mm}^{3}$ & $0,15 \mathrm{mil} / \mathrm{mm}^{3}$ & $0,21 \mathrm{mil} / \mathrm{mm}^{3}$ & $5,56 \mathrm{mil} / \mathrm{mm}^{3}$ & $4,04 \mathrm{mil} / \mathrm{mm}^{3}$ & $0,83 \mathrm{mil} / \mathrm{mm}^{3}$ & $0,10 \mathrm{mil} / \mathrm{mm}^{3}$ \\
\hline CVID02 & $* * *$ & $* * *$ & $* * *$ & **** & $* * *$ & $* * *$ & $* * *$ & **** & $* * *$ & $* * *$ & **** & **** & **** & $* * *$ & $* * *$ & **** \\
\hline CVID03 & $1,8 \mathrm{mil} / \mathrm{mm}^{3}$ & $0,10 \mathrm{mil} / \mathrm{mm}^{3}$ & $3,72 \mathrm{mil} / \mathrm{mm}^{3}$ & $3,77 \mathrm{mil} / \mathrm{mm}^{3}$ & $0,22 \mathrm{mil} / \mathrm{mm}^{3}$ & $0,56 \mathrm{mil} / \mathrm{mm}^{3}$ & $0,05 \mathrm{mil} / \mathrm{mm}^{3}$ & $3,10 \mathrm{mil} / \mathrm{mm}^{3}$ & $4,38 \mathrm{mil} / \mathrm{mm}^{3}$ & $0,11 \mathrm{mil} / \mathrm{mm}^{3}$ & $0,15 \mathrm{mil} / \mathrm{mm}^{3}$ & $0,13 \mathrm{mil} / \mathrm{mm}^{3}$ & $2,04 \mathrm{mil} / \mathrm{mm}^{3}$ & $4,06 \mathrm{mil} / \mathrm{mm}^{3}$ & $0 \mathrm{mil} / \mathrm{mm}^{3}$ & $0 \mathrm{mil} / \mathrm{mm}^{3}$ \\
\hline CVID04 & *** & $* * *$ & $* * *$ & $* * *$ & $* * *$ & $* * *$ & $* * *$ & $* * *$ & $* * *$ & $* * *$ & $* * *$ & $* * *$ & $* * *$ & $* * *$ & $* * *$ & $* * *$ \\
\hline CVID05 & $* * *$ & $* * *$ & $* * *$ & $* * *$ & $* * *$ & $* * *$ & $* * *$ & $* * *$ & $* * *$ & $* * *$ & $* * *$ & $* * *$ & $* * *$ & $* * *$ & $* * *$ & $* * *$ \\
\hline CVID06 & $1,3 \mathrm{mil} / \mathrm{mm}^{3}$ & $0,35 \mathrm{mil} / \mathrm{mm}^{3}$ & $5,65 \mathrm{mil} / \mathrm{mm}^{3}$ & $0,73 \mathrm{mil} / \mathrm{mm}^{3}$ & $1,13 \mathrm{mil} / \mathrm{mm}^{3}$ & $1,11 \mathrm{mil} / \mathrm{mm}^{3}$ & $0,48 \mathrm{mil} / \mathrm{mm}^{3}$ & $5,60 \mathrm{mil} / \mathrm{mm}^{3}$ & $0,88 \mathrm{mil} / \mathrm{mm}^{3}$ & $1,09 \mathrm{mil} / \mathrm{mm}^{3}$ & $0,89 \mathrm{mil} / \mathrm{mm}^{3}$ & $0,41 \mathrm{mil} / \mathrm{mm}^{3}$ & $5,41 \mathrm{mil} / \mathrm{mm}^{3}$ & $0,85 \mathrm{mil} / \mathrm{mm}^{3}$ & $1,29 \mathrm{mil} / \mathrm{mm}^{3}$ & $1,13 \mathrm{mil} / \mathrm{mm}^{3}$ \\
\hline CVID07 & $1,7 \mathrm{mil} / \mathrm{mm}^{3}$ & $0,28 \mathrm{mil} / \mathrm{mm}^{3}$ & $0,36 \mathrm{mil} / \mathrm{mm} 3$ & $0,16 \mathrm{mil} / \mathrm{mm}^{3}$ & $0,06 \mathrm{mil} / \mathrm{mm}^{3}$ & $0,25 \mathrm{mil} / \mathrm{mm}^{3}$ & $0,21 \mathrm{mil} / \mathrm{mm}^{3}$ & $0,79 \mathrm{mil} / \mathrm{mm}^{3}$ & $0,21 \mathrm{mil} / \mathrm{mm}^{3}$ & $0,40 \mathrm{mil} / \mathrm{mm}^{3}$ & $0,18 \mathrm{mil} / \mathrm{mm}^{3}$ & $0,28 \mathrm{mil} / \mathrm{mm}^{3}$ & $0,19 \mathrm{mil} / \mathrm{mm}^{3}$ & $0,09 \mathrm{mil} / \mathrm{mm}^{3}$ & $0,30 \mathrm{mil} / \mathrm{mm}^{3}$ & $0,06 \mathrm{mil} / \mathrm{mm}^{3}$ \\
\hline CVID08 & $1,9 \mathrm{mil} / \mathrm{mm}^{3}$ & $0,31 \mathrm{mil} / \mathrm{mm}^{3}$ & $3,63 \mathrm{mil} / \mathrm{mm}^{3}$ & $4,03 \mathrm{mil} / \mathrm{mm}^{3}$ & $0,08 \mathrm{mil} / \mathrm{mm}^{3}$ & $0,01 \mathrm{mil} / \mathrm{mm}^{3}$ & $0,24 \mathrm{mil} / \mathrm{mm}^{3}$ & $2,20 \mathrm{mil} / \mathrm{mm}^{3}$ & $4,01 \mathrm{mil} / \mathrm{mm}^{3}$ & $0,12 \mathrm{mil} / \mathrm{mm}^{3}$ & $0,07 \mathrm{mil} / \mathrm{mm}^{3}$ & $0,23 \mathrm{mil} / \mathrm{mm}^{3}$ & $2,80 \mathrm{mil} / \mathrm{mm}^{3}$ & $4,05 \mathrm{mil} / \mathrm{mm}^{3}$ & $0,08 \mathrm{mil} / \mathrm{mm}^{3}$ & $0,08 \mathrm{mil} / \mathrm{mm}^{3}$ \\
\hline CVID10 & $1,8 \mathrm{mil} / \mathrm{mm}^{3}$ & $1,06 \mathrm{mil} / \mathrm{mm}^{3}$ & $0,17 \mathrm{mil} / \mathrm{mm}^{3}$ & $0,37 \mathrm{mil} / \mathrm{mm}^{3}$ & $1,22 \mathrm{mil} / \mathrm{mm}^{3}$ & $2,86 \mathrm{mil} / \mathrm{mm}^{3}$ & $0,31 \mathrm{mil} / \mathrm{mm}^{3}$ & $1,19 \mathrm{mil} / \mathrm{mm}^{3}$ & $0,34 \mathrm{mil} / \mathrm{mm}^{3}$ & $0,64 \mathrm{mil} / \mathrm{mm}^{3}$ & $3,15 \mathrm{mil} / \mathrm{mm}^{3}$ & $0,27 \mathrm{mil} / \mathrm{mm}^{3}$ & $1,57 \mathrm{mil} / \mathrm{mm}^{3}$ & $0,49 \mathrm{mil} / \mathrm{mm}^{3}$ & $0,44 \mathrm{mil} / \mathrm{mm}^{3}$ & $3,17 \mathrm{mil} / \mathrm{mm}^{3}$ \\
\hline CVID11 & $* * *$ & $* * *$ & $* * *$ & $* * *$ & $* * *$ & $* * *$ & $* * *$ & $* * *$ & $* * *$ & $* * *$ & $* * *$ & $* * *$ & $* * *$ & $* * *$ & $* * *$ & $* * *$ \\
\hline CVID12 & $* * *$ & $* * *$ & $* * *$ & $* * *$ & $* * *$ & $* * *$ & $* * *$ & $* * *$ & $* * *$ & $* * *$ & $* * *$ & $* * *$ & $* * *$ & $* * *$ & **** & $* * *$ \\
\hline CVID13 & $2,1 \mathrm{mil} / \mathrm{mm}^{3}$ & $0,08 \mathrm{mil} / \mathrm{mm}^{3}$ & $1,41 \mathrm{mil} / \mathrm{mm}^{3}$ & $0,41 \mathrm{mil} / \mathrm{mm}^{3}$ & $2,30 \mathrm{mil} / \mathrm{mm}^{3}$ & $0,69 \mathrm{mil} / \mathrm{mm}^{3}$ & $0,12 \mathrm{mil} / \mathrm{mm}^{3}$ & $1,00 \mathrm{mil} / \mathrm{mm}^{3}$ & $0,09 \mathrm{mil} / \mathrm{mm}^{3}$ & $3,18 \mathrm{mil} / \mathrm{mm}^{3}$ & $0,04 \mathrm{mil} / \mathrm{mm}^{3}$ & $0,06 \mathrm{mil} / \mathrm{mm}^{3}$ & $1,53 \mathrm{mil} / \mathrm{mm}^{3}$ & $0,57 \mathrm{mil} / \mathrm{mm}^{3}$ & $2,15 \mathrm{mil} / \mathrm{mm}^{3}$ & $0,58 \mathrm{mil} / \mathrm{mm}^{3}$ \\
\hline CVID14 & $1,8 \mathrm{mil} / \mathrm{mm}^{3}$ & $0,41 \mathrm{mil} / \mathrm{mm}^{3}$ & $5,45 \mathrm{mil} / \mathrm{mm}^{3}$ & $7,25 \mathrm{mil} / \mathrm{mm}^{3}$ & $0,14 \mathrm{mil} / \mathrm{mm}^{3}$ & $0,11 \mathrm{mil} / \mathrm{mm}^{3}$ & $0,25 \mathrm{mil} / \mathrm{mm}^{3}$ & $4,50 \mathrm{mil} / \mathrm{mm}^{3}$ & $6,30 \mathrm{mil} / \mathrm{mm}^{3}$ & $0,30 \mathrm{mil} / \mathrm{mm}^{3}$ & $0,25 \mathrm{mil} / \mathrm{mm}^{3}$ & $0,23 \mathrm{mil} / \mathrm{mm}^{3}$ & $4,27 \mathrm{mil} / \mathrm{mm}^{3}$ & $5,92 \mathrm{mil} / \mathrm{mm}^{3}$ & $1,23 \mathrm{mil} / \mathrm{mm}^{3}$ & $0,54 \mathrm{mil} / \mathrm{mm}^{3}$ \\
\hline CVID15 & $* * *$ & **** & $* * *$ & $* * *$ & $* * *$ & $* * *$ & $* * *$ & $* * *$ & $* * *$ & $* * *$ & $* * *$ & $* * *$ & $* * *$ & $* * *$ & $* * *$ & $* * *$ \\
\hline CVID17 & **** & $* * *$ & $* * *$ & $* * *$ & $* * *$ & **** & **** & $* * *$ & $* * *$ & $* * *$ & $* * *$ & **** & $* * *$ & $* * *$ & $* * *$ & $* * *$ \\
\hline CVID19 & $* * *$ & $* * *$ & $* * *$ & $* * *$ & **** & $* * *$ & $* * *$ & $* * *$ & $* * *$ & $* * *$ & **** & $* * *$ & $* * *$ & **** & $* * *$ & **** \\
\hline
\end{tabular}

Freqüências individuais para cada um dos 4 subtipos de LB avaliados no grupo dos pacientes com ICV. Naive: LB naive; MZB: LB de Zona Marginal; SMB: Linfócito B de memória com troca de isotipo; PBL: plasmoblastos.

***: ausência de amostra. 
Anexo 14: Frequência dos Subtipos de Linfócitos B em Indivíduos Controles - Pós 3 Meses.

\begin{tabular}{|c|c|c|c|c|c|c|c|c|c|c|c|c|c|c|c|}
\hline \multicolumn{16}{|c|}{ Pós 3 Meses } \\
\hline & \multicolumn{5}{|c|}{ Basal } & \multicolumn{5}{|c|}{ Lisado Viral $20 \mathrm{ng} / \mathrm{mL}$} & \multicolumn{5}{|c|}{ HA $2,5 \mu \mathrm{g} / \mathrm{mL}$} \\
\hline & LB & Naive & MZB & SMB & PBL & LB & Naive & MZB & SMB & PBL & LB & Naive & MZB & SMB & PBL \\
\hline Identificação & $\%$ & $\%$ & $\%$ & $\%$ & $\%$ & $\%$ & $\%$ & $\%$ & $\%$ & $\%$ & $\%$ & $\%$ & $\%$ & $\%$ & $\%$ \\
\hline CTRL01 & $10,30 \%$ & $36,50 \%$ & $1,20 \%$ & $61,50 \%$ & $81,40 \%$ & $9,70 \%$ & $39,70 \%$ & $2,02 \%$ & $26,90 \%$ & $80,50 \%$ & $8,31 \%$ & $34,90 \%$ & $1,41 \%$ & $65,60 \%$ & $70,20 \%$ \\
\hline CTRL02 & $10,10 \%$ & $39,40 \%$ & $4,80 \%$ & $44,10 \%$ & $66,80 \%$ & $10,50 \%$ & $42,60 \%$ & $3,31 \%$ & $48,30 \%$ & $79,90 \%$ & $10,20 \%$ & $23,80 \%$ & $4,24 \%$ & $33,70 \%$ & $75,80 \%$ \\
\hline CTRL 03 & $9,83 \%$ & $44,20 \%$ & $6,70 \%$ & $16,30 \%$ & $75,20 \%$ & $11,00 \%$ & $13,30 \%$ & $2,26 \%$ & $11,20 \%$ & $80,80 \%$ & $9,56 \%$ & $41,40 \%$ & $7,14 \%$ & $8,93 \%$ & $72,00 \%$ \\
\hline CTRL04 & $13,20 \%$ & $26,30 \%$ & $5,98 \%$ & $15,60 \%$ & $68,90 \%$ & $6,84 \%$ & $35,40 \%$ & $5,91 \%$ & $7,22 \%$ & $80,40 \%$ & $7,83 \%$ & $23,10 \%$ & $4,70 \%$ & $4,57 \%$ & $81,50 \%$ \\
\hline CTRL05 & $20,20 \%$ & $39,80 \%$ & $14,50 \%$ & $20,60 \%$ & $52,60 \%$ & $13,00 \%$ & $48,90 \%$ & $16,10 \%$ & $7,55 \%$ & $60,70 \%$ & $16,90 \%$ & $36,20 \%$ & $13,10 \%$ & $14,60 \%$ & $66,70 \%$ \\
\hline CTRL06 & $3,95 \%$ & $26,20 \%$ & $3,47 \%$ & $35,10 \%$ & $78,00 \%$ & $7,19 \%$ & $35,30 \%$ & $3,49 \%$ & $11,80 \%$ & $76,60 \%$ & $6,43 \%$ & $30,70 \%$ & $5,30 \%$ & $11,60 \%$ & $73,90 \%$ \\
\hline CTRL07 & $9,51 \%$ & $17,10 \%$ & $6,11 \%$ & $5,61 \%$ & $73,10 \%$ & $8,17 \%$ & $19,50 \%$ & $10,10 \%$ & $1,76 \%$ & $75,20 \%$ & $4,61 \%$ & $25,20 \%$ & $7,88 \%$ & $5,74 \%$ & $76,70 \%$ \\
\hline CTRL08 & $13,80 \%$ & $41,90 \%$ & $18,10 \%$ & $12,30 \%$ & $10,50 \%$ & $20,10 \%$ & $49,00 \%$ & $21,00 \%$ & $15,00 \%$ & $50,20 \%$ & $23,50 \%$ & $48,70 \%$ & $13,40 \%$ & $20,90 \%$ & $43,90 \%$ \\
\hline CTRL09 & $7,32 \%$ & $79,60 \%$ & $55,20 \%$ & $5,09 \%$ & $7,47 \%$ & $7,55 \%$ & $74,40 \%$ & $35,50 \%$ & $6,20 \%$ & $12,20 \%$ & $9,58 \%$ & $77,50 \%$ & $45,30 \%$ & $6,09 \%$ & $11,70 \%$ \\
\hline CTRL10 & $* * *$ & **** & $* * *$ & $* * *$ & $* * *$ & $* * *$ & $* * *$ & $* * *$ & **** & **** & $* * *$ & $* * *$ & **** & **** & **** \\
\hline CTRL11 & $* * *$ & $* * *$ & $* *$ & $* *$ & $* * *$ & $* * *$ & $* * *$ & $* * *$ & $* * *$ & $* * *$ & $* * *$ & $* * *$ & $* * *$ & $* * *$ & $* * *$ \\
\hline CTRL12 & $5,15 \%$ & $33,50 \%$ & $16,30 \%$ & $7,20 \%$ & $7,44 \%$ & $2,92 \%$ & $47,40 \%$ & $14,70 \%$ & $3,88 \%$ & $12,20 \%$ & $3,47 \%$ & $34,40 \%$ & $10,00 \%$ & $6,63 \%$ & $15,20 \%$ \\
\hline CTRL13 & $6,94 \%$ & $73,70 \%$ & $35,30 \%$ & $7,66 \%$ & $3,24 \%$ & $6,62 \%$ & $63,10 \%$ & $14,10 \%$ & $8,60 \%$ & $4,16 \%$ & $3,47 \%$ & $70,00 \%$ & $24,80 \%$ & $8,11 \%$ & $5,36 \%$ \\
\hline CTRL14 & $7,12 \%$ & $56,90 \%$ & $13,50 \%$ & $16,10 \%$ & $6,18 \%$ & $7,17 \%$ & $52,90 \%$ & $13,60 \%$ & $25,00 \%$ & $8,63 \%$ & $6,97 \%$ & $46,30 \%$ & $12,20 \%$ & $22,00 \%$ & $7,53 \%$ \\
\hline CTRL15 & $4,68 \%$ & $14,90 \%$ & $1,81 \%$ & $73,30 \%$ & $11,20 \%$ & $2,88 \%$ & $15,30 \%$ & $2,80 \%$ & $76,60 \%$ & $7,81 \%$ & $3,35 \%$ & $11,90 \%$ & $1,59 \%$ & $79,00 \%$ & $6,46 \%$ \\
\hline CTRL16 & $* * *$ & $* * *$ & $* * *$ & $* * *$ & $* * *$ & $* * *$ & $* * *$ & $* * *$ & $* * *$ & $* * *$ & $* * *$ & $* * *$ & $* * *$ & $* * *$ & $* * *$ \\
\hline
\end{tabular}

Freqüências individuais para cada um dos 4 subtipos de LB avaliados no grupo dos pacientes com ICV. Naive: LB naive; MZB: LB de Zona Marginal; SMB: Linfócito B de memória com troca de isotipo; PBL: plasmoblastos.

***: ausência de amostra. 
Anexo 15: Frequência dos Subtipos de Linfócitos B em Pacientes com Imunodeficiência Comum Variável - Pós 6 Meses.

\begin{tabular}{|c|c|c|c|c|c|c|c|c|c|c|c|c|c|c|c|c|}
\hline \multicolumn{17}{|c|}{ Pós 6 Meses } \\
\hline & \multicolumn{6}{|c|}{ Basal } & \multicolumn{5}{|c|}{ Lisado Viral $20 \mathrm{ng} / \mathrm{mL}$} & \multicolumn{5}{|c|}{$\mathrm{HA} 2,5 \mu \mathrm{g} / \mathrm{mL}$} \\
\hline & Linfócitos Totais & LB & Naive & MZB & SMB & PBL & LB & Naive & MZB & SMB & PBL & LB & Naive & MZB & SMB & PBL \\
\hline Identificação & $\%$ & $\%$ & $\%$ & $\%$ & $\%$ & $\%$ & $\%$ & $\%$ & $\%$ & $\%$ & $\%$ & $\%$ & $\%$ & $\%$ & $\%$ & $\%$ \\
\hline CVID01 & $36,90 \%$ & $1,33 \%$ & $42,40 \%$ & $58,70 \%$ & $14,60 \%$ & $3,34 \%$ & $1,09 \%$ & $40,90 \%$ & $30,20 \%$ & $28,80 \%$ & $4,64 \%$ & $2,67 \%$ & $34,50 \%$ & $62,70 \%$ & $10,40 \%$ & $3,25 \%$ \\
\hline CVID02 & *** & $* * *$ & $* * *$ & $* * *$ & $* * *$ & $* * *$ & $* * *$ & $* * *$ & $* * *$ & $* * *$ & $* * *$ & $* * *$ & $* * *$ & $* * *$ & $* * *$ & $* * *$ \\
\hline CVID03 & $24 \%$ & $1,79 \%$ & $41,20 \%$ & $38,80 \%$ & $30,60 \%$ & $31,80 \%$ & $5,72 \%$ & $25,80 \%$ & $2,82 \%$ & $91,80 \%$ & $81,70 \%$ & $2,22 \%$ & $33,20 \%$ & $22,80 \%$ & $59,30 \%$ & $43,30 \%$ \\
\hline CVID04 & $36,80 \%$ & $5,48 \%$ & $37,20 \%$ & $43,70 \%$ & $15,20 \%$ & $3,49 \%$ & $14,60 \%$ & $35,10 \%$ & $8,08 \%$ & $17,70 \%$ & $0,71 \%$ & $14,40 \%$ & $61,40 \%$ & $7,10 \%$ & $11,50 \%$ & $4,83 \%$ \\
\hline CVID05 & $28,70 \%$ & $1,55 \%$ & $44,10 \%$ & $21,50 \%$ & $60,20 \%$ & $33,70 \%$ & $2,09 \%$ & $48,10 \%$ & $10,40 \%$ & $69,60 \%$ & $56,30 \%$ & $1,48 \%$ & $33,90 \%$ & $17,00 \%$ & $62,30 \%$ & $31,80 \%$ \\
\hline CVID06 & $* * *$ & \begin{tabular}{|l|}
$13,80 \%$ \\
\end{tabular} & $58,20 \%$ & $7,19 \%$ & $13,00 \%$ & $1,15 \%$ & $9,53 \%$ & $55,80 \%$ & $10,20 \%$ & $10,10 \%$ & $4,70 \%$ & $6,02 \%$ & $23,80 \%$ & $17,20 \%$ & $18,50 \%$ & $8,37 \%$ \\
\hline CVID07 & *** & $* * *$ & $* * *$ & $* * *$ & $* * *$ & $* * *$ & $* * *$ & $* * *$ & $* * *$ & $* * *$ & $* * *$ & $* * *$ & $* * *$ & $* * *$ & $* * *$ & $* * *$ \\
\hline CVID08 & $34 \%$ & $10,90 \%$ & $82,90 \%$ & $36,80 \%$ & $7,97 \%$ & $2,06 \%$ & $9,69 \%$ & $74,00 \%$ & $53,90 \%$ & $10,20 \%$ & $3,24 \%$ & $9,89 \%$ & $71,70 \%$ & $52,60 \%$ & $11,90 \%$ & $3,42 \%$ \\
\hline CVID10 & *** & $* * *$ & $* * *$ & $* * *$ & $* * *$ & $* * *$ & $* * *$ & $* * *$ & $* * *$ & $* * *$ & $* * *$ & $* * *$ & $* * *$ & $* * *$ & $* * *$ & $* * *$ \\
\hline CVID11 & *** & $* * *$ & $* * *$ & $* * *$ & $* * *$ & $* * *$ & $* * *$ & $* * *$ & $* * *$ & $* * *$ & $* * *$ & $* * *$ & $* * *$ & $* * *$ & $* * *$ & $* * *$ \\
\hline CVID12 & *** & $* * *$ & $* * *$ & $* * *$ & $* * *$ & $* * *$ & $* * *$ & $* * *$ & $* * *$ & $* * *$ & $* * *$ & $* * *$ & $* * *$ & $* * *$ & $* * *$ & $* * *$ \\
\hline CVID13 & *** & $* * *$ & $* * *$ & **** & $* * *$ & $* * *$ & $* * *$ & $* * *$ & $* * *$ & $* * *$ & **** & $* * *$ & $* * *$ & **** & $* * *$ & $* * *$ \\
\hline CVIDl4 & $30,50 \%$ & $2,99 \%$ & $60,70 \%$ & $19,30 \%$ & $13,60 \%$ & $19,30 \%$ & $33,40 \%$ & $33,70 \%$ & $21,90 \%$ & $32,10 \%$ & $41,90 \%$ & $32,00 \%$ & $35,20 \%$ & $30,20 \%$ & $28,80 \%$ & $42,30 \%$ \\
\hline CVID15 & *** & $* * *$ & $* * *$ & $* * *$ & $* * *$ & $* * *$ & $* * *$ & $* * *$ & $* * *$ & $* * *$ & $* * *$ & $* * *$ & $* * *$ & $* * *$ & $* * *$ & $* * *$ \\
\hline CVID17 & *** & $* * *$ & $* * *$ & **** & $* * *$ & $* * *$ & $* * *$ & $* * *$ & **** & $* * *$ & **** & $* * *$ & $* * *$ & $* * *$ & $* * *$ & **** \\
\hline CVID19 & *** & $42,00 \%$ & $33,90 \%$ & $14,80 \%$ & $5,68 \%$ & $19,80 \%$ & $21,60 \%$ & $52,10 \%$ & $17,70 \%$ & $7,60 \%$ & $4,10 \%$ & $22,50 \%$ & $55,10 \%$ & $14,90 \%$ & $12,10 \%$ & $8,34 \%$ \\
\hline
\end{tabular}

Freqüências individuais para cada um dos 4 subtipos de LB avaliados no grupo dos pacientes com ICV. Naive: LB naive; MZB: LB de Zona Marginal; SMB: Linfócito B de memória com troca de isotipo; PBL: plasmoblastos.

***: ausência de amostra. 
Anexo 16: Valores Absolutos dos Subtipos de Linfócitos B em Pacientes com Imunodeficiência Comum Variável - Pós 6 Meses.

\begin{tabular}{|c|c|c|c|c|c|c|c|c|c|c|c|c|c|c|c|c|}
\hline \multicolumn{17}{|c|}{ Pós 6 Meses } \\
\hline & \multicolumn{6}{|c|}{ Basal } & \multicolumn{5}{|c|}{ Lisado Viral $20 \mathrm{ng} / \mathrm{mL}$} & \multicolumn{5}{|c|}{ HA $2,5 \mu \mathrm{g} / \mathrm{mL}$} \\
\hline & Linfócitos Totais & LB & Naive & MZB & SMB & PBL & LB & Naive & MZB & SMB & PBL & LB & Naive & MZB & SMB & PBL \\
\hline Identificação & Abs. & Abs. & Abs. & Abs. & Abs. & Abs. & Abs. & Abs. & Abs. & Abs. & Abs. & Abs. & Abs. & Abs. & Abs. & Abs. \\
\hline CVID01 & $.7 \mathrm{mil} / \mathrm{mm}^{3}$ & $0,10 \mathrm{mil} / \mathrm{mm}^{3}$ & $3,10 \mathrm{mil} / \mathrm{mm}^{3}$ & $158,49 \mathrm{mil} / \mathrm{mm}^{3}$ & $1,07 \mathrm{mil} / \mathrm{mm}^{3}$ & $0,24 \mathrm{mil} / \mathrm{mm}^{3}$ & $0,08 \mathrm{mil} / \mathrm{mm}^{3}$ & $2,99 \mathrm{mil} / \mathrm{mm}^{3}$ & $2,21 \mathrm{mil} / \mathrm{mm}^{3}$ & $2,11 \mathrm{mil} / \mathrm{mm}^{3}$ & $0,34 \mathrm{mil} / \mathrm{mm}^{3}$ & $0,20 \mathrm{mil} / \mathrm{mm}^{3}$ & $2,52 \mathrm{mil} / \mathrm{mm}^{3}$ & $4,59 \mathrm{mil} / \mathrm{mm}^{3}$ & $0,76 \mathrm{mil} / \mathrm{mm}^{3}$ & $0,24 \mathrm{mil} / \mathrm{mm}^{3}$ \\
\hline CVID02 & **** & **** & **** & $* * *$ & **** & **** & $* * *$ & $* * *$ & **** & **** & **** & **** & $* * *$ & **** & **** & **** \\
\hline CVID03 & $1,5 \mathrm{mil} / \mathrm{mm}^{3}$ & $0,11 \mathrm{mil} / \mathrm{mm}^{3}$ & $2,58 \mathrm{mil} / \mathrm{mm}^{3}$ & $2,425 \mathrm{mil} / \mathrm{mm}^{3}$ & $1,91 \mathrm{mil}^{\mathrm{mm}} \mathrm{m}^{3}$ & $1,99 \mathrm{mil} / \mathrm{mm}^{3}$ & $0,36 \mathrm{mil} / \mathrm{mm}^{3}$ & $1,61 \mathrm{mil} / \mathrm{mm}^{3}$ & $0,18 \mathrm{mil} / \mathrm{mm}^{3}$ & $5,74 \mathrm{mil} / \mathrm{mm}^{3}$ & $5,11 \mathrm{mil} / \mathrm{mm}^{3}$ & $0,14 \mathrm{mil} / \mathrm{mm}^{3}$ & $2,08 \mathrm{mil} / \mathrm{mm}^{3}$ & $1,43 \mathrm{mil} / \mathrm{mm}^{3}$ & $3,71 \mathrm{mil} / \mathrm{mm}^{3}$ & $2,71 \mathrm{mil} / \mathrm{mm}^{3}$ \\
\hline CVID04 & $3,2 \mathrm{mil} / \mathrm{mm}^{3}$ & $0,48 \mathrm{mil} / \mathrm{mm}^{3}$ & $3,23 \mathrm{mil} / \mathrm{mm}^{3}$ & $3,8 \mathrm{mil} / \mathrm{mm}^{3}$ & $1,32 \mathrm{mil} / \mathrm{mm}^{3}$ & $0,30 \mathrm{mil} / \mathrm{mm}^{3}$ & $1,27 \mathrm{mil} / \mathrm{mm}^{3}$ & $3,05 \mathrm{mil} / \mathrm{mm}^{3}$ & $0,70 \mathrm{mil} / \mathrm{mm}^{3}$ & $1,54 \mathrm{mil} / \mathrm{mm}^{3}$ & $0,06 \mathrm{mil} / \mathrm{mm}^{3}$ & $1,25 \mathrm{mil} / \mathrm{mm}^{3}$ & $5,34 \mathrm{mil} / \mathrm{mm}^{3}$ & $0,62 \mathrm{mil} / \mathrm{mm}^{3}$ & $1 \mathrm{mil} / \mathrm{mm}^{3}$ & $0,42 \mathrm{mil} / \mathrm{mm}^{3}$ \\
\hline CVID05 & $2 \mathrm{mil} / \mathrm{mm}^{3}$ & $0,11 \mathrm{mil} / \mathrm{mm}^{3}$ & $3,07 \mathrm{mil} / \mathrm{mm}^{3}$ & $1,50 \mathrm{mil} / \mathrm{mm}^{3}$ & $4,20 \mathrm{mil} / \mathrm{mm}^{3}$ & $2,35 \mathrm{mil} / \mathrm{mm}^{3}$ & $0,15 \mathrm{mil} / \mathrm{mm}^{3}$ & $3,35 \mathrm{mil} / \mathrm{mm}^{3}$ & $0,72 \mathrm{mil} / \mathrm{mm}^{3}$ & $4,85 \mathrm{mil} / \mathrm{mm}^{3}$ & $3,92 \mathrm{mil} / \mathrm{mm}^{3}$ & $0,10 \mathrm{mil} / \mathrm{mm}^{3}$ & $2,36 \mathrm{mil} / \mathrm{mm}^{3}$ & $1,18 \mathrm{mil} / \mathrm{mm}^{3}$ & $4,34 \mathrm{mil} / \mathrm{mm}^{3}$ & $2,22 \mathrm{mil} / \mathrm{mm}^{3}$ \\
\hline CVID06 & **** & $* * *$ & $* * *$ & $* * *$ & **** & **** & $* * *$ & $* * *$ & $* * *$ & $* * *$ & **** & **** & **** & $* * *$ & **** & **** \\
\hline CVID07 & **** & **** & **** & **** & **** & **** & **** & **** & **** & **** & **** & **** & **** & $* * *$ & $* * *$ & **** \\
\hline CVID08 & $1,9 \mathrm{mil} / \mathrm{mm}^{3}$ & $0,61 \mathrm{mil} / \mathrm{mm}^{3}$ & $4,63 \mathrm{mil} / \mathrm{mm}^{3}$ & $2,06 \mathrm{mil} / \mathrm{mm}^{3}$ & $0,45 \mathrm{mil} / \mathrm{mm}^{3}$ & $36,86 \mathrm{mil} / \mathrm{mm}^{3}$ & $0,54 \mathrm{mil} / \mathrm{mm}^{3}$ & $4,14 \mathrm{mil} / \mathrm{mm}^{3}$ & $3,01 \mathrm{mil} / \mathrm{mm}^{3}$ & $0,57 \mathrm{mil} / \mathrm{mm}^{3}$ & $0,18 \mathrm{mil} / \mathrm{mm}^{3}$ & $0,55 \mathrm{mil} / \mathrm{mm}^{3}$ & $3,99 \mathrm{mil} / \mathrm{mm}^{3}$ & $2,94 \mathrm{mil} / \mathrm{mm}^{3}$ & $0,67 \mathrm{mil} / \mathrm{mm}^{3}$ & $0,19 \mathrm{mil} / \mathrm{mm}^{3}$ \\
\hline $\mathrm{CV}$ & $* * *$ & $* * *$ & **** & $* * *$ & **** & **** & $* * *$ & $* * *$ & **** & $* * *$ & **** & $* * *$ & $* * *$ & $* * *$ & **** & **** \\
\hline $\mathrm{CVI}$ & **** & $* * *$ & $* * *$ & $* * *$ & $* * *$ & $* * *$ & $* * *$ & $* * *$ & $* * *$ & $* * *$ & $* * *$ & $* * *$ & $* * *$ & $* * *$ & $* * *$ & $* * *$ \\
\hline CVID12 & **** & $* * *$ & **** & **** & **** & **** & **** & $* * *$ & $* * *$ & $* * *$ & $* * *$ & $* * *$ & $* * *$ & $* * *$ & $* * *$ & $* * *$ \\
\hline CVID13 & **** & $* * *$ & **** & **** & **** & **** & **** & **** & **** & **** & **** & $* * *$ & **** & $* * *$ & **** & **** \\
\hline CVID14 & $1,8 \mathrm{mil} / \mathrm{mm}^{3}$ & $0,18 \mathrm{mil} / \mathrm{mm}^{3}$ & $3,58 \mathrm{mil} / \mathrm{mm}^{3}$ & $1,14 \mathrm{mil} / \mathrm{mm}^{3}$ & $0,80 \mathrm{mil} / \mathrm{mm}^{3}$ & $1,14 \mathrm{mil} / \mathrm{mm}^{3}$ & $1,97 \mathrm{mil} / \mathrm{mm}^{3}$ & $1,99 \mathrm{mil} / \mathrm{mm}^{3}$ & $1,29 \mathrm{mil} / \mathrm{mm}^{3}$ & $1,89 \mathrm{mil} / \mathrm{mm}^{3}$ & $2,47 \mathrm{mil} / \mathrm{mm}^{3}$ & $1,89 \mathrm{mil} / \mathrm{mm}^{3}$ & $2,08 \mathrm{mil} / \mathrm{mm}^{3}$ & $1,78 \mathrm{mil} / \mathrm{mm}^{3}$ & $1,70 \mathrm{mil} / \mathrm{mm}^{3}$ & $2,50 \mathrm{mil}^{2} \mathrm{~mm}^{3}$ \\
\hline CVID15 & $* * *$ & $* * *$ & **** & $* * *$ & **** & **** & $* * *$ & **** & $* * *$ & $* * *$ & **** & $* * *$ & $* * *$ & $* * *$ & $* * *$ & $* * *$ \\
\hline $\mathrm{CV}$ & **** & **** & **** & **** & **** & $* * *$ & $* * *$ & **** & **** & **** & **** & **** & **** & ***** & $* * *$ & $* * *$ \\
\hline CVID19 & $* * *$ & $* * *$ & $* * *$ & $* * *$ & $* * *$ & $* * *$ & $* * *$ & $* * *$ & $* * *$ & $* * *$ & $* * *$ & $* * *$ & $* * *$ & $* * *$ & $* * *$ & $* * *$ \\
\hline
\end{tabular}

Freqüências individuais para cada um dos 4 subtipos de LB avaliados no grupo dos pacientes com ICV. Naive: LB naive; MZB: LB de Zona Marginal; SMB: Linfócito B de memória com troca de isotipo; PBL: plasmoblastos.

***: ausência de amostra. 
Anexo 17: Frequência dos Subtipos de Linfócitos B em Indivíduos Controles - Pós 6 Meses.

\begin{tabular}{|c|c|c|c|c|c|c|c|c|c|c|c|c|c|c|c|}
\hline \multicolumn{16}{|c|}{$\begin{array}{l}\text { Pós } 6 \text { Meses } \\
\end{array}$} \\
\hline & \multicolumn{5}{|c|}{ Basal } & \multicolumn{5}{|c|}{ Lisado Viral $20 \mathrm{ng} / \mathrm{mL}$} & \multicolumn{5}{|c|}{ HA $2,5 \mu \mathrm{g} / \mathrm{mL}$} \\
\hline & LB & Naive & MZB & SMB & PBL & LB & Naive & MZB & SMB & PBL & LB & Naive & MZB & SMB & PBL \\
\hline Identificação & $\%$ & $\%$ & $\%$ & $\%$ & $\%$ & $\%$ & $\%$ & $\%$ & $\%$ & $\%$ & $\%$ & $\%$ & $\%$ & $\%$ & $\%$ \\
\hline CTRL01 & $1,35 \%$ & $24,20 \%$ & $29,10 \%$ & $11,10 \%$ & $3,19 \%$ & $1,16 \%$ & $30,40 \%$ & $23,60 \%$ & $10,40 \%$ & $6,45 \%$ & $1,23 \%$ & $19,60 \%$ & $22,50 \%$ & $12,60 \%$ & $4,39 \%$ \\
\hline CTRL02 & $5,03 \%$ & $62,10 \%$ & $27,50 \%$ & $18,30 \%$ & $7,72 \%$ & $4,08 \%$ & $55,30 \%$ & $23,30 \%$ & $33,20 \%$ & $8,16 \%$ & $3,54 \%$ & $58,80 \%$ & $12,50 \%$ & $26,40 \%$ & $5,44 \%$ \\
\hline CTRL03 & $3,01 \%$ & $38,00 \%$ & $6,87 \%$ & $81,20 \%$ & $17,90 \%$ & $5,10 \%$ & $50,90 \%$ & $1,13 \%$ & $79,20 \%$ & $74,10 \%$ & $2,63 \%$ & $40,60 \%$ & $7,05 \%$ & $78,60 \%$ & $10,40 \%$ \\
\hline CTRL04 & $1,03 \%$ & $29,70 \%$ & $19,10 \%$ & $50 \%$ & $3,21 \%$ & $0,73 \%$ & $42,00 \%$ & $18,30 \%$ & $29,90 \%$ & $2,43 \%$ & $1,30 \%$ & $37,70 \%$ & $15,30 \%$ & $19,50 \%$ & $4,27 \%$ \\
\hline CTRL05 & $3,44 \%$ & $59,90 \%$ & $38,70 \%$ & $38,60 \%$ & $1,14 \%$ & $2,35 \%$ & $46,00 \%$ & $16,00 \%$ & $52,20 \%$ & $4,38 \%$ & $1,54 \%$ & $42,40 \%$ & $21,40 \%$ & $43,80 \%$ & $5,47 \%$ \\
\hline CTRL06 & **** & $* * *$ & $* * *$ & $* * *$ & **** & $* * *$ & $* * *$ & ***** & $* * *$ & $* * *$ & **** & **** & ***** & **** & **** \\
\hline CTRL07 & $0,38 \%$ & $27,90 \%$ & $9,52 \%$ & $52,40 \%$ & $4,76 \%$ & $1,47 \%$ & $1,40 \%$ & $7,65 \%$ & $48,50 \%$ & $9,67 \%$ & $0,61 \%$ & $31,40 \%$ & $1,50 \%$ & $44,30 \%$ & $5,04 \%$ \\
\hline CTRL08 & $3,58 \%$ & $48,80 \%$ & $18,50 \%$ & $42,30 \%$ & $15,80 \%$ & $2,37 \%$ & $42,70 \%$ & $13,70 \%$ & $51,40 \%$ & $11,70 \%$ & $2,95 \%$ & $52,40 \%$ & $14,60 \%$ & $51,70 \%$ & $18,80 \%$ \\
\hline CTRL09 & $72,60 \%$ & $25,10 \%$ & $3,02 \%$ & $2,46 \%$ & $6,92 \%$ & $43,50 \%$ & $37,80 \%$ & $5,04 \%$ & $29,60 \%$ & $23,10 \%$ & $44,60 \%$ & $34,70 \%$ & $1,58 \%$ & $33,30 \%$ & $19,10 \%$ \\
\hline CTRL10 & $* * *$ & $* * *$ & $* * *$ & $* * *$ & $* * *$ & $* * *$ & $* * *$ & **** & $* * *$ & $* * *$ & $* * *$ & **** & $* * *$ & $* * *$ & $* * *$ \\
\hline CTRL11 & $* * *$ & $* * *$ & $* * *$ & $* * *$ & $* * *$ & $* * *$ & $* * *$ & $* * *$ & $* * *$ & $* * *$ & $* * *$ & $* * *$ & $* * *$ & **** & $* * *$ \\
\hline CTRL12 & $7,53 \%$ & $57,00 \%$ & $14,30 \%$ & $15,40 \%$ & $20,30 \%$ & $35,20 \%$ & $36,70 \%$ & $7,76 \%$ & $44,70 \%$ & $53,20 \%$ & $37,00 \%$ & $32,40 \%$ & $36,60 \%$ & $23,20 \%$ & $26,20 \%$ \\
\hline CTRL13 & $* * *$ & $* * *$ & $* * *$ & $* * *$ & **** & $* * *$ & $* * *$ & $* * *$ & $* * *$ & $* * *$ & $* * *$ & $* * *$ & $* * *$ & $* * *$ & **** \\
\hline CTRL14 & $29,70 \%$ & $29,90 \%$ & $9,98 \%$ & $38,70 \%$ & $29,50 \%$ & $41,80 \%$ & $42,10 \%$ & $35,50 \%$ & $13,20 \%$ & $33,80 \%$ & $36,20 \%$ & $39,20 \%$ & $20,50 \%$ & $22,30 \%$ & $25,50 \%$ \\
\hline CTRL15 & $17,50 \%$ & $39,10 \%$ & $19,00 \%$ & $9,51 \%$ & $12,40 \%$ & $16,90 \%$ & $30,00 \%$ & $17,80 \%$ & $8,30 \%$ & $11,20 \%$ & $14,40 \%$ & $36,80 \%$ & $15,90 \%$ & $14,90 \%$ & $6,63 \%$ \\
\hline CTRL16 & $* * *$ & **** & **** & $* * *$ & **** & $* * *$ & $* * *$ & $* * *$ & $* * *$ & $* * *$ & $* * *$ & $* * *$ & $* * *$ & $* * *$ & $* * *$ \\
\hline
\end{tabular}

Freqüências individuais para cada um dos 4 subtipos de LB avaliados no grupo dos pacientes com ICV. Naive: LB naive; MZB: LB de Zona Marginal; SMB: Linfócito B de memória com troca de isotipo; PBL: plasmoblastos.

***: ausência de amostra. 
Anexo 18: Classificação EUROclass em Pacientes com ICV Após a Subdivisão doTipo de Resposta Após a Vacinação.

\begin{tabular}{|c|c|}
\hline Paciente & EUROclass \\
\hline \multicolumn{2}{|r|}{$\overline{\text { G1 }}$} \\
\hline CVID03 & $\mathrm{LB}>1 \% / \mathrm{SMB} \leq 2 \% / \mathrm{CD} 21^{\mathrm{low}} \geq 10 \%$ \\
\hline CVID06 & $\mathrm{LB}>1 \% / \mathrm{SMB}>2 \% / \mathrm{CD} 21^{\text {low }} \geq 10 \%$ \\
\hline CVID07 & $\mathrm{LB}<1 \%$ \\
\hline CVID10 & $\mathrm{LB}>1 \% / \mathrm{SMB} \leq 2 \% / \mathrm{CD} 21^{\mathrm{low}} \geq 10 \%$ \\
\hline CVID15 & $\mathrm{LB}>1 \% / \mathrm{SMB} \leq 2 \% / \mathrm{LB}$ Trans $\geq 9 \%$ \\
\hline CVID19 & $\mathrm{LB}>1 \% / \mathrm{SMB}>2 \% / \mathrm{CD} 21^{\text {low }}<10 \%$ \\
\hline \multicolumn{2}{|r|}{ G2 } \\
\hline CVID01 & $* * *$ \\
\hline CVID08 & $* * *$ \\
\hline CVID12 & $\mathrm{LB}>1 \% / \mathrm{SMB}>2 \% / \mathrm{CD} 21^{\mathrm{low}} \geq 10 \%$ \\
\hline CVID14 & $\mathrm{LB}>1 \% / \mathrm{SMB} \leq 2 \% / \mathrm{LB}$ Trans $<9 \%$ \\
\hline \multicolumn{2}{|r|}{ G3 } \\
\hline CVID04 & $\mathrm{LB}>1 \% / \mathrm{SMB}>2 \% / \mathrm{CD} 21^{\mathrm{low}}<10 \%$ \\
\hline CVID05 & $\mathrm{LB}>1 \% / \mathrm{SMB} \leq 2 \% / \mathrm{CD} 21^{\text {low }} \geq 10 \%$ \\
\hline CVID17 & $* * *$ \\
\hline
\end{tabular}

G1: pacientes que aumentaram a expressão de SMB e PBL após a vacinação;

G2: pacientes que aumentaram a expressão apenas de SMB após a vacinação;

G3: pacientes que não apresentaram aumento na expressão de SMB apenas para PBL. SMB: linfócito B de memória com troca de isotipo.

$\mathrm{CD} 21^{\text {low }}$ : LB CD21 low.

LB Trans: LB Transitório.

***: Pacientes que não apresentam classificação EUROclass. 


\section{Determinação de Anticorpos Específicos para Influenza}

Tampão de Lavagem

1) Pipetar $100 \mathrm{~mL}$ do concentrado SeroWP em $900 \mathrm{~mL}$ de água destilada.

2) Caso o tampão apresente cristais, incubar em banho maria a $37^{\circ} \mathrm{C}$ até sua diluição.

\section{Determinação de Anticorpos Específicos para H1N1}

$R D E$

1) Diluir o RDE em 20 mL de solução fisiológica

Antígeno H1N1

1) Pipetar $1 \mathrm{~mL}$ do antígeno e completar com mais $9 \mathrm{~mL}$ de PBS, diluição 1/10.

2) Manter no gelo e homogeneizar vigorosamente, antes de pipetar.

\section{Hemácias}

1) No dia anterior ao ensaio, deve ser coletado amostra de sangue de galinha ou peru, e mantê-la em geladeira.

2) No dia seguinte, lavar as hemácias com PBS por 5 minutos a $250 \mathrm{xg}$.

3) Em seguida, realizar nova lavagem com PBS por 10 minutos a $300 \mathrm{xg}$.

4) Diluir as hemácias em PBS, em diluição 1/10.

5) Antes de ser utilizado, realizar nova diluição para uso na reação a 1/20.

6) No momento em que forem utilizadas, as hemácias devem ser pipetadas em pipeta de vidro e bem lentamente.

\section{Determinação de Anticorpos Específicos para S. pneumoniae}

Tampão PBS $20 x$

1) Pesar $13,84 \mathrm{~g}$ de fosfato de sódio monobásico $\left(\mathrm{NaH}_{2} \mathrm{PO}_{4}\right)$.

2) Pesar $42,4 \mathrm{~g}$ de fosfato de sódio bifásico anidro $\left(\mathrm{Na}_{2} \mathrm{HPO}_{4}\right)$.

3) Pesar $340 \mathrm{~g}$ de cloreto de sódio $(\mathrm{NaCl})$. 
4) Em um béquer, adicionar os volumes pesados previamente e completar com 2 litros de água destilada.

5) Acertar o $\mathrm{pH}$ para 7,4

6) Alicotar em frascos de $100 \mathrm{~mL}$ e manter a uma temperatura de $-20^{\circ} \mathrm{C}$ até o seu uso.

\section{Tampão PBS $1 x$}

1) Em um béquer, adicionar $50 \mathrm{~mL}$ de PBS 20x.

2) Completar com $950 \mathrm{~mL}$ de água destilada.

3) Armazenar a uma temperatura de $-4^{\circ} \mathrm{C}$ até o seu uso.

Tampão BSA-PBS Tween

1) Pesar $10 \mathrm{~g}$ de BSA a $1 \%$.

2) Em um béquer adicionar o volume pesado previamente e completar com 1litro de PBS 1x.

3) Pipetar $1 \mathrm{~mL}$ de Tween $20 \%$ e adicionar à solução

4) Alicotar em garrafas de vidro contendo $80 \mathrm{~mL}$ e armazenar a uma temperatura de $-20^{\circ} \mathrm{C}$ até o seu uso.

Obs.: Descongelar 1 dia antes de seu uso para evitar contaminação e sempre utilizálo em temperatura ambiente.

\section{Tampão Citrato-Fosfato}

1) Pesar 7,4 g de ácido cítrico monohidratado $\left(\mathrm{C}_{6} \mathrm{H}_{8} \mathrm{O}_{7} \mathrm{H}_{2} \mathrm{O}\right)$.

2) Pesar $9,94 \mathrm{~g}$ de fosfato de sódio bifásico anidro $\left(\mathrm{Na}_{2} \mathrm{HPO}_{4}\right)$.

3) Em um béquer, adicionar os volumes pesados previamente e completar com 1litro de água destilada.

4) Acertar o $\mathrm{pH}$ para 5,0.

5) Alicotar em frascos de $100 \mathrm{~mL}$ e manter a uma temperatura de $-20^{\circ} \mathrm{C}$ até o seu uso. 


\section{Tampão de Lavagem}

1) Em um balão volumétrico, adicionar $50 \mathrm{~mL}$ de tampão PBS $20 \mathrm{x}$.

2) Adicionar $1 \mathrm{~mL}$ de Tween $20 \%$.

3) Completar o volume com $950 \mathrm{~mL}$ de água destilada.

Obs.: por experimento são utilizados em torno de 5 litros deste tampão.

\section{Tampão A}

1) Em um tubo tipo falcon, adicionar $3 \mathrm{~mL}$ do tampão BSA - PBS Tween.

2) Acrescentar $15 \mu \mathrm{l}$ de Poly $\mathrm{C}$.

3) Acrescentar $12 \mu \mathrm{l}$ do sorotipo $22 \mathrm{~F}$.

\section{Tampão B}

1) Em um tubo tipo falcon, adicionar $800 \mu 1$ do tampão BSA - PBS Tween.

2) Em seguida, pipetar $4 \mu 1$ de Poly $\mathrm{C}$.

\section{Conjugado}

1) Em um béquer, adicionar $32 \mathrm{~mL}$ de tampão BSA - PBS Tween.

2) Adicionar $8 \mu 1$ de anti-IgG humana marcada com peroxidase.

\section{Substrato}

1) Em um béquer, adicionar $75 \mathrm{~mL}$ do tampão citrato - fosfato.

2) Dissolver 3 pastilhas de OPD na concentração final de $30 \mathrm{mg} / \mathrm{mL}$.

3) Em seguida, adicionar $30 \mu \mathrm{l}$ de peróxido de hidrogênio $30 \%\left(\mathrm{H}_{2} \mathrm{O}_{2}\right)$.

4) Até a sua utilização, manter a solução no escuro e embrulhada em papel alumínio.

\section{Ácido Sulfúrico}

1) Em uma proveta, adicionar cuidadosamente $30 \mathrm{~mL}$ de ácido sulfúrico $2,5 \mathrm{~N}$ $\left(\mathrm{H}_{2} \mathrm{SO}_{4}\right)$.

2) Cuidadosamente e aos poucos, adicionar $402 \mathrm{~mL}$ de água destilada.

3) Armazenar em temperatura ambiente e em um frasco de vidro âmbar previamente identificado. 